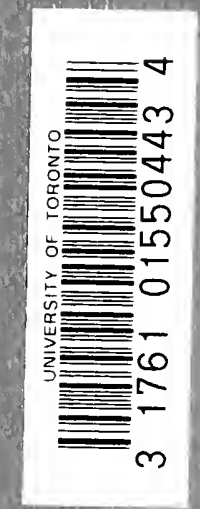




\section{Digitized by the Internet Archive in 2007 with funding from \\ Microsoft Corporation}





\section{Publications of the \\ Carnegie Endowment for International Peace Division of Economics and History \\ John Bates Clark, Director}




\title{
JAPANESE MONOGRAPHS
}

\author{
EDITED BY \\ BARON Y. SAKATANI, D.C.L. \\ Formerly Minister of Finance of Japan
}

Conscription System in Japan, by Gotaro Ogawa.

Expenditures of the Russo-Japanese War, by Gotaro Ogawa.

Military Industries of Japan, by Ushisaburo Kobayashi.

War and Armament Loans of Japan, by Ushisaburo Kobayashi.

War and Armament Taxes of Japan, by Ushisaburo Kobayashi.

Expenditures of the Sino-Japanese War, by Giichi Ono.

War and Armament Expenditures of Japan, by Giichi Ono. 


\section{MILITARY INDUSTRIES \\ OF JAPAN}

$\mathrm{BY}$

USHISABURO KOBAYASHI, D. C. L.

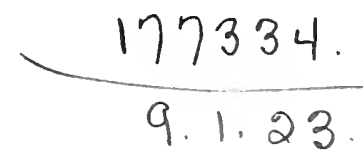

NEW YORK

OXFORD UNIVERSITY PRESS AMERICAN BRANCH: 35 WeSt 32ND StreEt • LONDON, TORONTO, MELBOURNE, AND BOMBAY 
COPYRIGHT I922

BY THE

CARNEGIE ENDOWMENT FOR INTERNATIONAL PEACE

THE RUMFORD PRESS, CONCORD, N. H. 


\section{NOTE BY THE DIRECTOR}

The plans of the Division of Economics and History of the Carnegie Endowment for International Peace have been transformed by the World War. Problems now calling for study transcend in importance those with which this Division has been dealing and material for research and record so far transcends any that was formerly available that it will demand almost exclusive attention for some years to come. A new world has evolved suddenly out of the world which we knew and the transformation extends to the foundations of government and of economic life.

The process of warfare itself is now so unlike that of former days that many military rules of the past have gone into the scrap basket. The late war ended when its deadliest tools had barely been brought into action. The peoples have fought as they had worked, by machinery, mechanical and chemical engines of destruction have decided the result and will decide in like manner the result of all wars of the future. Machine shops and chemical laboratories will so largely determine what armies shall win that fighting strength will be as much a matter of available capital and of science in applying it as of numbers of troops and strategy in directing them. It is safe to say that the death dealing arts and instruments will far surpass in destructiveness those which made the late war so deadly, and to a soldier of the future the order to march into a cloud of poisonous gas and a whirlwind of missiles will resemble an order to plunge into the rapids of Niagara. This is one central and obvious fact which the war has taught us and it has many corollaries, some of which have to do with the increased costs of war and the importance of the particular resources that make a nation powerful for offense and defense; but there are less conspicuous economic facts which are more fundamental, since they may determine where and when, if at all, wars shall hereafter occur.

Causes of warfare are always partly economic and those which incited the recent one were mainly so. The business plans of a powerful state reached to the ends of the earth 
and so crossed and interlaced the claims of other states that some writers, then and afterwards, pronounced the war inevitable. If we assume a settled purpose on the part of such a state to encroach on the rights of others, we may say that it doubtless was inevitable. The victory of the defending countries has saved them from an immediate and intolerable domination, but it can not be taken as an assured fact that similar attempts will never again be made. The economic inducement continues and the means may at some time be forthcoming.

Within the several states war has democratized industry, giving to labor an increase of control-a change that if continued will entail momentous consequences; but still greater effects have been produced on the relations of states to each other. The world as a whole has changed more than its component parts and the new relation of the parts to one another is the critical element in the situation. The great increase in the economic functions of governments is one cause of this condition. Within the great international community in which the several states are units extensive economic functions have gravitated into the hands of governments and caused them to face each other as business rivals and to deal with each other in a multitude of ways in which the merely self-seeking policy of private business is intolerable. Power to invoke principles of justice and international law as interpreted by a competent court has become an indispensable means of allaying strife and this fact exalts to supreme importance the high court of nations which has just been established. It magnifies also the importance of the economic facts and principles with which the law itself will have to deal. It is not merely individual men or private corporations who now meet each other in the rough and tumble of a world-wide mart but states themselves, each representing its own population and seeking to foster its interests as a zealous and faithful agent. The chances of friction that are inherent in ordinary commerce inhere today in vast international transactions and will increase in the measure in which the intercourse grows. All this means a 
great increase in incentives to warfare, on the one hand, and in the motives for preventing it, on the other. Private commerce unites more than it separates those who participate in it, and it remains to be seen whether international commerce will act in the same way; but, in view of what modern war means, the human race will deserve to perish, and much of it will probably do so, if the forces of strife are allowed to get the upper hand. Whether they will or not-whether the recent economic changes will tend to reduce warfare or to increase it-depends on the ability of nafions to create and maintain the instrumentalities that in the new state of the world are necessary.

Certain it is that the feeling which prevails today, the world over, is not one of security. The dread of further war is greater than it wąs before r9I4. In some areas war still prevails, in others peace is held by a precarious tenure and in all it can be firmly established only by conscious and intelligent action by the states themselves. Mere exhaustion holds war dogs temporarily in leash, but it will take more than that to tame them as they must be tamed if peace is to endure.

We here confront a wide difference between the several states in comparative desire for peace and disposition to maintain it. One portentous fact is the grim determination of Russian communists to extend their system by crude force from state to state. Bolshevism is government by the few and largely the bad masquerading as government for and by the people. In its mother country, Russia, the economic measure by which it began its career was confiscation of private wealth-in itself an ultra-democratic measure. If this had brought in a true communism, it would have been a ruthless and unjust measure for creating a peace-loving state. A just and orderly democratizing of industry in the several states would give new strength to the forces of peace, and it would be highly improbable that any state so influenced would try to extend its system over foreign countries by military invasion. Democracy, socialism, communism and bolshevism all appear in the aftermath of the war. The first of 
them makes for future peace and so does even the conservative element in the second, while all else in the series means certainty of civil strife and danger of international war.

The fact that during the war governments had to take on innumerable functions that were formerly in private hands has lent an impetus to socialism and to the perverted growths that have accompanied it, and it has created a new international system the meaning of which is profoundly significant, though he who runs can not so easily read it. There are dangerous features in the system which the war evoked and, happily for mankind, there are available safeguards which were evoked with them and need to be retained if human effort can do it.

By a compulsion that there was no resisting, the war forced the nations of the Entente into economic cooperation with each other. Commissions centering finally in the Supreme Economic Council adjusted in a harmonious way questions that would otherwise have led to rivalry and conflicting action in purchasing war materials, securing ships, apportioning food, controlling railroads, financing the war and doing a multitude of other things with the one common purpose of victory. The special compulsion of the struggle is over, but it has left an aftermath of issues grave enough to make peace insecure unless something equivalent to the Supreme Economic Council survives in full efficiency. The agency that did so much to win the war can do so much to prevent another one, but to that end it will have to be guided by economic principles and it is a saving fact that these still survive. The war has not abolished the law of demand and supply, though governments may forget it. In the coming era they must build better than they now know. Economic knowledge must either go in advance of action and prevent disaster or follow action and be learned from disaster. Beyond computation is the importance of attaining the knowledge and using it when evil impends and prevention is possible.

New York, John Bates Clark,

September 27, 1920.

Director. 


\section{PREFACE}

The present investigation has been accomplished chiefly by Mr. Norimoto Masuda, Bachelor of Law and captain. For the purpose of collecting special materials, he personally visited government and public offices and private companies, and, traveling to many distant localities, inspected factories and cities, to secure the utmost accuracy of detail in the work.

The main subject of this investigation is the military industry, in relation to which historical statistics and economical influences are discussed. The author, utilizing his experience gained during his long military service and his complete knowledge of military affairs and political economy, has succeeded in introducing minutely the history of armor and the development of the mechanical industry of Japan to European and American countries, and for this purpose almost all the statistics of military and general industries are inserted in his work.

It is true that the armament and military industry of Japan has often encouraged an excessively rapid progress not parallel with the development of finance and economy and has seriously affected the latter. At the same time, however, it must be admitted that the military industry has not only accomplished the purpose of the country in every war, but has given strong protection and encouragement to general industries and means of communication relating thereto, and by constantly instructing private industry has been an everlasting fountain for diffusing technical art, by all of which it has brought Japanese industries at large to the conditions that are in existence at the present time. Secondly, as to foreign trade, the rapid enlargement of armament, accompanied by increasing imports of armor and ships, formed the most powerful cause of the excess of imports of the country for a long time, and this led to a great difficulty in keeping specie at home. In recent times, however, owing to the gradual development of industries, both military and general, a remarkable decrease of imports took place in armor and ships, as well as in all 
military commodities, almost everything being manufactured at home. Finally, as to social affairs, the conditions of labor in the military industry, which is more advanced than general industry, raised the latter in no small degree. Especially the habits and sanitary precautions of the laborer in the former are no doubt by far better than those of the latter, for in the military circles there prevail strict order, thorough carefulness and continuous encouragement. After all, even though the military industry has sometimes had a bad influence upon finance and foreign trade, yet it has had a very good effect upon general industry, means of communication and society.

In conclusion, let me add a word. Most of the matters relating to the military industry are not open to investigation like those of general industry, but are kept secret in many cases, and even if not so kept, neither statistics nor other material are well furnished. I have great respect for the author's work, because, in spite of all those obstacles, his earnest and exhaustive labor has succeeded, and I recommend it as the only one of its kind in the publication world of Japan.

Ushisaburo Kobayashi.

Tokyo, Japan, March, I9I6. 


\section{BIBLIOGRAPHY}

\section{Books}

Departament of Agriculture and Commerce:

Annual Reports of Foreign Trade (Gaikoku Bōeki Nenpōo), I9I2.

Development of Mining in Japan (Honpō Kōgyō no Süsei), I9I 3.

Armiy Department :

History of Ordnance in Japan (Nihon Keiki Enkaku Shi), I88o.

Military Annual Statistics (Rikugun Tōkei Nenpō), I9I2.

Cabinet Statistics Bureau:

Statistical Yearbook of the Japanese Empire (Nihon Teikoku Tōkei Nenkan), I882-1913.

Materials for Statistics of the Movement of Population (Jinkō Dōtai oyobi Seitai ni kansuru Tōkei Zairyōo), I9I3.

General Staff of Japan:

History of the Sino-Japanese War (Nisshin Senshi), 1904-1907.

History of the Russo-Japanese War (Nichiro Senshi), I9I2.

NAYy Departaient:

Naval Department Annual Reports (Kaigunshō Nenpō), I875-1913.

Naval General Staff Office:

History of the Naval Warfare of $27^{-28}$ Meiji (Meiji Nijushsichi Hachi Nen Kaisen shi), I905.

History of the Naval Warfare of 37-38 Meiji (Meiji Sanjüshichi Hachi Nen Kaisen Shi), I909.

Tokyo Mining Supervision Station:

History of Mining in Japan (Nihon Kōgyō Shi ), I9I I.

Treasury Departient :

Treasury Department Annual Reports (Ōkurashō Nenpō), I875-19I2.

Unyu Nippo sha (Office of Transportation Journal, Tokyo): History of Transportation during the Meiji Era (Meiji Unyu Shi), I9I3.

\section{Manuscripts}

Materials for investigation especially collected by the government, public offices and companies at the request of the commission, and manuscripts written by the compiler from his inspection of the following offices and factories: 
Amarube Town Office,

Atsuta Weapon Manufactory,

Edamitsu Iron Works,

Hiroshima Branch of Military

Clothing Department,

Hiroshima Branch of Military

Provision Department, Japan Steel Works,

Kawasaki Dockyard,

Kure Municipal Office,

Kure Aaval Arsenal,

Maizuru Naval Arsenal,

Maizuru Town Office,

Military Clothing Department,

Military Provision Department,

Mitsubishi Dockyard,

Moji Weapon Manufactory,

Naval Arsenal,
Navy Department,

Osaka Arsenal,

Osaka Branch of Military Clothing Department,

Osaka Branch of Military Provision Department,

Osaka Iron Works,

Sasebo Municipal Office,

Sasebo Naval Arsenal,

Senju Woolen Cloth Factory,

Tokuyama Briquette Manufactory,

Uji Powder Mill,

Uraga Dock Company,

Tokyo Arsenal,

Var Department,

Yokosuka Municipal Office,

Yokosuka Naval Arsenal. 


\section{EXPLANATORY TABLES}

\section{Value of Japanese Currencies}

Japan adopted the gold standard system in $187 \mathrm{I}$, but the inconvertible paper money became principal currency a few years later. In I 886 the paper money became convertible into silver and after that date the Japanese currency system was the silver standard de facto, until on October I, I897, the gold standard system was legally adopted. The figures necessary to ascertain the value of Japanese currencies are given below:

(I) I gold yen (according to Coinage Law of I87I) contains I.5 gramme pure gold.

(2) I gold yen (according to Coinage Law of I 897) contains 0.75 gramme pure gold.

(3) I silver yen contains 24.26I gramme pure silver.

(4) The value of I silver yen in the English currency (according to the demand rate of exchange on London in the average of the year) is as follows:

\begin{tabular}{|c|c|c|c|c|c|}
\hline & s. d. & & s. d. & & $\begin{array}{l}\text { s. d. } \\
3.04 \cdot 5\end{array}$ \\
\hline $\begin{array}{l}\text { I } 874 \ldots \ldots \ldots \\
\text { I } 875 \ldots \ldots \ldots\end{array}$ & 4.02 .0 & $1882 \ldots \ldots \ldots$ & 3.08 .8 & $\begin{array}{l}1890 \ldots \ldots \\
I 891 \ldots\end{array}$ & $\begin{array}{l}3.04 .5 \\
2.02 .6\end{array}$ \\
\hline 1876. & $\begin{array}{l}4.00 .0 \\
3.11 .2\end{array}$ & I $884 \ldots$ & $\begin{array}{l}3.07 .9 \\
3.07 .9\end{array}$ & $1892 \ldots \ldots \ldots$ & 2.10 .5 \\
\hline 1877. & 3.11 .7 & $1885^{\circ}$ & 3.06 .0 & 1893. & 2.06 .7 \\
\hline I 878. & 3.09 .4 & I $886 \ldots$ & 3.03 .2 & I 894 . & 2.01 .2 \\
\hline I 879 & 3.08 .0 & $\mathbf{I} 887 \ldots \ldots \ldots$ & 3.02 .0 & 1895. & 2.01 .3 \\
\hline I 88 & 3.08 .9 & $\ldots$ & 3.01 .0 & 1896. & 2.02 .0 \\
\hline 88 & 3.08 .4 & 1889. & 3.01 .1 & 1897. & 2.00 .4 \\
\hline
\end{tabular}

(5) The value of I yen of paper money in the English currency (calculated on the basis of the above mentioned exchange rate and the quotations of the silver price in the Tokyo Exchange in the average of the year) is as follows:

\begin{tabular}{|c|c|c|c|c|c|}
\hline & $\begin{array}{l}\text { s. d. } \\
3 \cdot 10.1\end{array}$ & I $880 \ldots \ldots \ldots$ & $\begin{array}{l}\text { s. d. } \\
2.06 .4\end{array}$ & I 883. & $\begin{array}{l}\text { s. d. } \\
2.10 .7\end{array}$ \\
\hline$\ldots$ & 3.05 .6 & $1881 \ldots \ldots \ldots$ & $2.02 . I$ & I 884. & $3.04 \cdot 3$ \\
\hline . & 3.00 .3 & $1882 \ldots \ldots \ldots$ & $2.04 \cdot 5$ & 1885 & $3.03 \cdot 7$ \\
\hline
\end{tabular}

(6) I $r y \bar{o}$ (unit of value of the old currency system) was declared in the Coinage Law of I87I to be equal to I yen.

\section{Chronological Table}

\begin{tabular}{|c|c|}
\hline Meiji & Ist \\
\hline & $2 \mathrm{~d}$ \\
\hline " & 4th \\
\hline 16 & $5^{\text {th }}$ \\
\hline “ & 6 th \\
\hline “" & 7th \\
\hline " & gth \\
\hline “ & Ioth \\
\hline “ & I I th \\
\hline "1 & I2th \\
\hline 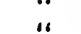 & I $3^{\text {th }}$ \\
\hline & \\
\hline
\end{tabular}

1868 A. D.
1869
1870
1871
1872
1873
1874
1875
1876
1877
1878
1879
1880
1881

$\begin{array}{cc}\text { Meiji } ~ & 5 \text { th } \\ \text { " } & \text { I6th } \\ \text { " } & 17 \text { th } \\ \text { " } & \text { I } 8 \text { th } \\ \text { " } & \text { 19th } \\ \text { " } & 2 \text { oth } \\ \text { " } & 2 \text { Ist } \\ \text { " } & 22 \mathrm{~d} \\ \text { " } & 23 \mathrm{~d} \\ \text { " } & 24 \text { th } \\ \text { " } & 25 \text { th } \\ \text { " } & 26 \text { th } \\ \text { " } & 27 \text { th } \\ \text { " } & 28 \text { th }\end{array}$

I882 A. D.
I 883
1884
1885
1886
1887
1888
1889
1890
1891
1892
1893
1894
1895




\section{Chronological Table-(Continued)}

\begin{tabular}{|c|c|}
\hline Mei & i 29tl \\
\hline “ & 3otl \\
\hline ““ & 315 \\
\hline "4 & 33 \\
\hline " & $34^{\mathrm{tl}}$ \\
\hline 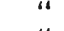 & $35^{\mathrm{t}}$ \\
\hline & $36 \mathrm{tl}$ \\
\hline & 874 \\
\hline & \\
\hline & \\
\hline
\end{tabular}

1896 A. D.
1897 “"
1898
$1899 ~ “ ، ~$
1900
1901
1902
1903
1904
1905
1906
1907

\begin{tabular}{|c|c|}
\hline Meiji & 4Ist \\
\hline & $42 \mathrm{~d}$ \\
\hline & $\begin{array}{r}430 \\
44 \text { th }\end{array}$ \\
\hline 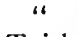 & 45 th \\
\hline Taish & \\
\hline & \\
\hline . & \\
\hline ، & \\
\hline “" & \\
\hline
\end{tabular}

I908 A. D.

1909

I9I0

I9I I

1912

1913 “

1914 “

1915 "

1916 "

1917

Weights, Measures and Money

With English, American, French and German Equivalents

\begin{tabular}{|c|c|c|c|c|}
\hline Japan & $\begin{array}{l}\text { Great } \\
\text { Britain }\end{array}$ & $\begin{array}{l}\text { U. S. of } \\
\text { America }\end{array}$ & France & Germany \\
\hline $\begin{aligned} R i & =36 C h \bar{o} \\
& =2, \mathrm{I} 60 \mathrm{Ken} \\
& =\mathrm{1} 2,960 \text { Shaku. }\end{aligned}$ & $\begin{array}{l}2 \cdot 44030 \\
\text { Miles }\end{array}$ & $\begin{array}{l}2.44029 \\
\text { Miles }\end{array}$ & $\begin{array}{l}3.92727 \\
\text { Kiloms. }\end{array}$ & $\begin{array}{l}\text { 3. } 92727 \\
\text { Kiloms. }\end{array}$ \\
\hline$R i$ (Marine). & $\begin{array}{l}\text { I } 15 \text { I } 52 \\
\text { Miles }\end{array}$ & $\begin{array}{l}\text { I. I5 I } 5 \text { I } \\
\text { Miles }\end{array}$ & $\begin{array}{l}\text { I. } 853 \text { I } 8 \\
\text { Kiloms. }\end{array}$ & $\begin{array}{l}\text { I. } 85318 \\
\text { Kiloms. }\end{array}$ \\
\hline Square $R i$ & $\begin{array}{l}5.955^{05} \\
\text { Sq. Miles }\end{array}$ & $\begin{array}{l}5.9550 \text { I } \\
\text { Sq. Miles }\end{array}$ & $\begin{array}{l}\text { I5.42347 } \\
\text { Km. Carrés }\end{array}$ & $\begin{array}{l}\mathrm{I} 5.42347 \\
\text { Quadrat } \mathrm{Km}\end{array}$ \\
\hline $\begin{aligned} C h o & =10 \operatorname{Tan} \\
& =100 \mathrm{Se} \\
& =3, \operatorname{coo} B u .\end{aligned}$ & $\begin{array}{l}2.45064 \\
\text { Acres }\end{array}$ & $\begin{array}{l}2 \cdot 45^{\circ 62} \\
\text { Acres }\end{array}$ & $\begin{array}{l}99 \cdot 17355 \\
\text { Ares }\end{array}$ & $\begin{array}{l}99 . \text { I } 7355 \\
\text { Ar. }\end{array}$ \\
\hline $\begin{aligned} T_{s u b o} & =\mathrm{I} 0 G \bar{o} \\
& =\mathrm{I} 0 \mathrm{OO} \text { Shaku.. }\end{aligned}$ & $\begin{array}{l}3.95369 \\
\text { Sq. Yards }\end{array}$ & $\begin{array}{l}\text { 3. } 95367 \\
\text { Sq. Yards }\end{array}$ & $\begin{array}{l}3.30579 \\
\text { Centiares. }\end{array}$ & $\begin{array}{l}3.30579 \\
\text { Quadratm. }\end{array}$ \\
\hline $\begin{aligned} \text { Koku } & =10 T o \\
& =100 S h \bar{o} \\
& =1,000 G \bar{o} \\
& =10,000 S h a k u . .\end{aligned}$ & $\begin{array}{l}4.96005 \\
\text { Bushels }\end{array}$ & $\left\{\begin{array}{l}47.65389 \\
\text { Gallons (Liq.) } \\
5 . \text { I I902 } \\
\text { Bushels (Dry) }\end{array}\right.$ & $\begin{array}{l}\text { I. } 8039 \text { I } \\
\text { Hectolitres }\end{array}$ & $\begin{array}{l}\text { r.8039I } \\
\text { Hectolitres }\end{array}$ \\
\hline $\begin{array}{c}\text { Koku (Capacity of } \\
\text { ship) } \\
\ldots \ldots \ldots \ldots \ldots\end{array}$ & $\begin{array}{l}\text { I/ Io of } \\
\text { one Ton }\end{array}$ & $\begin{array}{l}\text { I/Io of } \\
\text { one Ton }\end{array}$ & $\begin{array}{l}\text { I/ro } \\
\text { de Tonne }\end{array}$ & $\begin{array}{l}\text { I/Io } \\
\text { Tonne }\end{array}$ \\
\hline $\begin{aligned} \text { Kwan } & =\mathrm{I}, \mathrm{o00} \text { Momme } \\
& =\mathrm{I} 0,000 \text { Fun } \\
& =\mathrm{I} 00,000 \text { Rin... }\end{aligned}$ & $\begin{array}{l}8.26733 \\
\text { lbs. (Avoir.) } \\
\text { Io.047 I I } \\
\text { lbs. (Troy) }\end{array}$ & $\begin{array}{l}8.26733 \\
\text { lbs. (Avoir.) } \\
\text { Io.o47 I I } \\
\text { lbs. (Troy) }\end{array}$ & $\begin{array}{l}3.75000 \\
\text { Kilogs. }\end{array}$ & $\begin{array}{l}3 \cdot 75000 \\
\text { Kilogs. }\end{array}$ \\
\hline$K i n=160$ Momme. & $\begin{array}{l}\text { I. } 32277 \\
\text { lbs. (Avoir.) } \\
\text { I. } 60754 \\
\text { lbs. (Troy) }\end{array}$ & $\begin{array}{l}\text { I. } 32277 \\
\text { lbs. (Avoir.) } \\
\text { I. } 60754 \\
\text { lbs. (Troy) }\end{array}$ & $\begin{array}{l}\text { o. } 60000 \\
\text { Kilogs. }\end{array}$ & $\begin{array}{l}\text { o. } 60000 \\
\text { Kilogs. }\end{array}$ \\
\hline $\begin{aligned} Y_{e n} & =100 \mathrm{Sen} \\
& =1,000 \mathrm{Rin} \\
& =10,000 \mathrm{M} \bar{o} .\end{aligned}$ & $\begin{array}{l}\text { 2.o. } 5^{82} \\
\text { s. d. }\end{array}$ & $\begin{array}{l}\text { o.4984 } \\
\text { Dollar }\end{array}$ & $\begin{array}{l}2 \cdot 5^{83} \\
\text { Francs }\end{array}$ & $\begin{array}{l}2.0924 \\
\text { Marks }\end{array}$ \\
\hline
\end{tabular}




\section{CONTENTS}

Part I-Historical Survey of the Military Industries

CHAPTER

PAGE

I Introduction .................... 3

II From the Restoration to the Sino-Japanese Var 27

III From the Sino-Japanese IVar to the Russo-Japanese $\operatorname{Var} \ldots \ldots \ldots \ldots \ldots \ldots \ldots \ldots \ldots \ldots . \ldots \ldots$

IV From the Russo-Japanese War to the Present Time.................... 85

Part II-Economic Effects of the

Military Industries

I Introduction $\ldots \ldots \ldots \ldots \ldots \ldots \ldots \ldots \ldots \ldots \ldots \ldots \ldots$

II Effects on Industrial Policy ............. I63

III Effects on Manufacturing Industry......... I 80

IV Effects on Primitive Industry ............ 203

V Effects on Commerce .............. 21 2

VI Efferts on Communication ............. 223

VII Social Effects ................. $2+1$

VIII Conclusion.................... 259

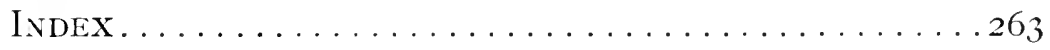





\section{PART I \\ HISTORICAL SURVEY OF THE MILITARY INDUSTRIES}





\section{CHAPTER I}

\section{INTRODUCTION}

The source of the present development of the military industry in Japan owes its origin mainly to her intercourse with Europe and America, opened in the latter part of the Tokugawa Shogunate, when Japan felt the necessity of making military implements and building warships with all the latest improvements known in civilized countries; when she set about importing various kinds of machinery, at the same time engaged competent engineers from those countries, and began for the first time to make war implements and build warships on a large scale with up-to-date machinery.

As to our native military implements, the art and skill of making such implements had reached their highest degree in a way special to the nation, as, for instance, in such things as our native swords, "Katana," and suits of armor, of which we can safely boast as being the finest specimens of craftsmanship in the world. Although firearms were introduced into Japan about three hundred years before the era of Meiji, they were scarcely used in war and not looked upon as indispensable military implements until the days of the revolutionary war which followed immediately upon the resignation of the last Shogun of the House of Tokugawa. Fighting in the olden times for the most part consisted of hand to hand combat, and bows and arrows were used instead of firearms. The principal military implements in those days were suits of armor, "horo" (textile shields), bows and arrows, swords, lances, "naginata" (long handled falchions), "konbo" (long sticks made of iron or hard wood), saddles and harness, banners, bells and drums, "umajirushi" (banners or signs, of the general or commander of the force), shields, tent and curtains.

These military implements were mostly made by hand, and 
each of them required special art and skill on the part of the artisans employed in the work, so that it was almost impossible for them to be made by machinery; this is the reason why the military implement industry in Japan was very limited until the recent era, and it was the more so, as there was then no kind of mechanical industry known in Japan. Not only was there no factory equipped with any machinery; there was not even a factory worth mentioning with any number of hands engaged at work at any one place. In addition to the above, it must be borne in mind that those days were not like the present time in Japan, where the conscription system has now been enforced and certain standard uniforms and implements are given to each and every soldier; while with a few exceptions the men in the old days had their costumes or implements made according to their own fancies and ideas and according to their ranks and positions. Therefore there was absolutely no necessity for large factories, as there never was any occasion for having an order to manufacture any one thing in any quantity within a given time.

In the history of the military industry in Japan before the era of Meiji, the art and skill of individual artisans are the only subjects that are worthy of notice, and from the economic point of view the old system of the industry does not teach us anything special for the present essay, and, even if there were anything, it is almost impossible to treat it here, owing to the lack of available statistics. This is the reason why we treat principally the development of the industry after the Restoration of Meiji. But even though inconspicuous in industry, we must, nevertheless, refer to some of our old military implements which might have some connection with the present manufacture, so as to facilitate clear insight and enable the reader to grasp fully the present development of the industry in Japan, and for this purpose, we shall narrate briefly hereunder the history of the development of some of the principal old military implements which we consider to have some relation to the present industry. 


\section{SMALl ARMS}

There are differing opinions among historians as to when hand guns, known generally by the ancient Japanese under the name "teppo," were first imported into Japan, and the exact time is not known at present. But according to the opinion most popularly believed among the natives, the first instance of the importation of firearms into this country was on the $25^{\text {th }}$ day of August in the 8th year (some say the I2th year) of the Temmon Era (I539 or I543). More than one hundred Dutch merchants (also said to be Portuguese) led by Francisco and Christo vao da Mota arrived at Tanegashima, a small island belonging to the province of Osumi, Kyushu, their ship being blown off its due course by a storm, and landed at Kokura, a small harbor in the village of Nishimura on that island, where, with the aid of a Chinese scholar named Goho, who came on the same ship with them, they asked the governor of the island Tanegashima, Hyobunosuke Tokitaka, to allow them to enter into commercial intercourse with the natives, and at the request of the governor sold him a number of hand guns they had brought with them. On the same occasion, it is said, the Governor of Tanegashima entertained those foreign guests very cordially, and asked them to teach him the mode of shooting and handling a gun and also the method of making gunpowder. The hand gun imported then was a muzzle-loader, measuring 3 feet and 7.2 inches in its whole length and 0.72 inch in caliber, and it was perhaps one of those match-locks which were produced in Spain during the fourteenth century. It was not long before Tokitaka and his men became quite skilful in shooting and moreover they tried, as is natural, to make firearms with their own hands, but failed in making perfect ones because they could not understand some points of the weapon. In the next year Dutch merchants came again to the island accompanied by a smith skilled in the work of gun making. After some time Tokitaka got several of his men thoroughly instructed in the work of a gunsmith, and at last he succeeded in making hundreds of perfect hand guns solely by the work of the natives, hence "Tanegashima-tsutsu" 
("tsutsu" meaning a barrel or "teppo") became another name common in this country for small arms. The example given by Tanegashima was followed by Ashikaga, the Shogun of the time, and many feudal lords, so that the work of gunsmiths soon became common in all parts of the country. Among others a certain citizen of Sakai, a harbor and town in the province of Izumi, who went early to Tanegashima and studied gun making, began a prosperous business in his native town, and his abundant products were widely distributed throughout the whole country. Guns made in those times were not uniform in size and shape, some improvements having been made after they were first imported. The barrel was made of steel and fixed in a stock made of oak; a lock made of brass was so devised that on pulling the trigger the cock dropped and struck against the lock and produced the discharge.

Soon after the first importation of firearms, Japan reached the epoch called by historians "Sengoku Jidai" (civil war period), when incessant hostilities between feudal lords caused the manufacture of weapons of all kinds known at that time to be very active, and gun making was even attempted in every part of the country. Notwithstanding the needs of the time, the use of firearms was comparatively limited, for it was considered by all people that to shoot an enemy with a gun from a distance was a cowardly deed, because it was contrary to the doctrine of "Bushido" that the right and most honorable way to fight consisted in meeting the enemy face to face and with cold steel.

At last in the time of Toyotomi, which immediately followed the "Sengoku Jidai," regiments armed with "teppo" were formed besides those armed with bows and arrows; and thus the use of hand guns was gradually extended. After that, and especially after the Tokugawa Shogunate was established, skill in the practice of shooting grew more and more advanced; yet as to the industry of firearms no sign of progress was visible during the course of about two hundred years, until the era of Kokwa (I844-1847). The reason for 
this may be explained as follows: Although Japan entered in the $14^{\text {th }}$ year of the Keicho Era (1609) into a treaty of commerce with Holland, her government remained still attached to the policy of closing her country and people against all foreigners, and allowed no person without authority or a license for the purpose to have intercourse with any of them, even though he was a Dutchman, or to study any work or product of Occidental civilization. The interdict was carried out strictly when the matter concerned military affairs, for example, military instruments or military science. In addition to the policy adopted by the government, the undisturbed. peace which continued through those two hundred years may also account for the dullness in the industry of gun making.

In and after the era of Tempo (I830-I 843), foreign ships frequently visited this country and gradually aroused the nation, who at last grew anxious to understand foreigners better and began to study both their persons and their productions. Many of the natives, especially men of the learned class, went to Nagasaki, which was the only port then open to foreigners, and endeavored secretly to learn the sciences and arts of Europe from Dutchmen, who were then the only foreigners permitted to land in this country. Among other things, even gunnery was studied by some of those private students, who in turn taught the art to their countrymen. At last the government of the Shogun, and all clans, urged by the demand of the time, determined to have soldiers trained in gunnery, and instructed their people to follow their own example. Thus all the people of the country began to pay more attention to the importation of weapons as well as to the domestic manufacture of the same.

The first importation of firing mechanism guns took place just at that time and placed the gun making of this country in a position ready for an advance. Above all, the visit of Commodore Perry of the United States of America in the 6th year of Kaei (1853) caused violent agitation, and all persons who recognized the crisis of their country insisted upon the pressing necessity of national defense. The government, 
by the aid of Takashima Shirodayu, a renowned master of gunnery, and some others, purchased abroad warships and weapons through the medium of Dutch merchants. At the same time the making of firearms was encouraged everywhere in the country, and many contrivances were attempted for their improvement. Even a quick-firing gun was invented by a feudal lord, Sanada Shinano-no-kami, who presented some specimens of the same to the Shogun of the time. At last, the government, being eager to encourage domestic industry, announced in the 6th year of Ansei (I859) that liberty was given to private individuals (who had hitherto been forbidden) to transfer firearms by purchase and sale.

Notwithstanding these remarkable effects on both the government and the people, firearms of domestic manufacture were by no means perfect and their efficiency and accuracy were not to be compared with those of the guns imported from Europe. Therefore, the Shogun and other feudal lords purchased most of their arms abroad through the medium of Dutchmen; and a considerable number of weapons was thus imported yearly, the largest of imports being those recorded in the era of Bunkyu (186I-I863). All the small arms imported in these years were such as had been made in Holland after the type of the years I830-1845 and called in this country the Gewehr musket. A musket of this sort consists of a smooth bored barrel of forged iron and is provided with a sight and a double springed lock. A stud for a bayonet, though it was annexed to the margin of the muzzle of the musket, was utterly useless in those days, when a Japanese warrior carried always a "Katana" (sword) about his waist but never a bayonet. Besides the Gewehr rifle, some kinds of carbines and pistols were also imported during the same period. Soon after the first importation of the Gewehr musket, many of the feudal lords ordered their smiths to make imitations, and finally succeeded in their efforts; so that it was not long before the army of every feudal lord in the country was amply furnished with muskets of the same type. But soon after, the government of the Shogun in the Keio Era 
(I 865-I867) engaged officers and non-commissioned officers of the French Army as teachers of a military school to train the native soldiers, and according to the opinion of those French officers determined to adopt the rifles of the Minie type. All the feudal lords who had hitherto used the Gewehr and other muskets indiscriminately recognized the simplicity of handling and the superior effect of discharge in the new rifles, and many of them displaced the former guns with the latter. About this time the government ordered Egawa Tarozaemon, who was quite a master of both gun making and gunnery of the time, to teach the men sent from all clans for the purpose. These facts were the cause of the notable advancement which we find before the dawn of the Meiji Era in military tactics as well as in the industry of gun making in this country. The progress was so remarkable that the match-lock muskets, the only firearms known by the natives until thirty years ago, became now very rare objects, difficult to find anywhere in this country, and the clans were not slow in trying to get ahead of one another in using the rifle with firing mechanism.

\section{Machine Guns}

The machine gun produced first in this country was invented by a certain Inatomi Ichimu in the era of Kwan-ei (I 824-1843) and was one capable of discharging twenty shots in succession. About the same time another one, consisting of twenty barrels, each with a match-lock, was invented by Inouye Geki, and some specimens of the same which had been made under the guidance of a renowned mechanic named Kunitomo Jindayu were presented to Tokugawa Iyemitsu, the Shogun of the time. All those machine guns were, of course, very immature in both design and work compared with those of the present day. They were so heavy and bulky that they were rather fit for a stationary gun than to be carried by a man. After this, machine guns of the type of either a native invention or a foreign one were produced here and there in the country, but they are hardly worth mentioning in the line of industry. 


\section{GuNs}

\section{Smooth-Bored Guns}

The importation of guns took place about the same time as that of small arms, and the first instance of their practical use in war occurred when they were used in the armies of the lords Oda and Otomo during the period from the era of Temmon to that of Tensho ( I532-I59I). But, owing to the topographical features of the country and the imperfect state of the roads and means of transportation in those times; instances of the practical use of guns in the field were very rare, the use having been limited to bombarding a castle or a sea fight. The guns first imported into Japan were those made in France, and hence guns of the same type were called "Fransu." Previously, guns of this sort had been imported into China under the reign of the Ming dynasty from Spain and Portugal; and they were imported into Japan either directly from these European countries or indirectly through the medium of the Chinese. The first gun made by the hand of a domestic artisan was that forged after the "Fransu" type by the order of Toyotomi Hideyoshi in the Ist year of the era of Bunroku (I592). In the r6th year of Keicho (I6II) Shibatsuji Rizayemon Michinari of Sakai, a famous port town in Izumi Province, produced a muzzle-loading gun which was made of white cast iron and whose caliber measured I foot and ro feet in the length of gun barrel and was capable of emitting a charge weighing $12 \frac{1}{2}$ pounds. A so-called "Wariu-dsutsu" (the term meaning a gun of Japanese type) in those times had a screw to close the breech, and was provided with a notch of the back sight placed in front of, and at the distance of four times of the caliber from the touch-hole, and foresight fixed at the upper edge of the muzzle, but mostly with no trunnion.

In the early times of the Tokugawa Shogunate, the use of guns was still very limited, more limited than that of small arms; so that there was no trace of advancement in the industry of gun making. But in the 6th year of Keicho (I60I) 
Tokugawa Iyeyasu instructed his men to practice gunnery, and then Inouye Geki and Nakamura Wakasanokami jointly devised a rest for a gun turnable in every direction and named it "Sempudai." It produced a remarkable effect afterward in the war called "Osaka-jin," when it was employed to destroy the castle of Osaka.

In the era of Kwan-ei (I624-I643) some Dutchmen came to this country and held under their guidance an examination in gun firing on the field of Meguro. The gun was a mortar of ancient type, 4 feet and 0.4 inch in length and $I$ foot and 3 feet I I inches in caliber; its bullet weighed 7 I $6 \frac{2}{3}$ pounds in lead or $54 \mathrm{I} \frac{2}{3}$ pounds in copper. The examination was for the purpose of acquiring a more accurate knowledge of both gunnery and gun making, and preparing for the manufacture of guns in the future.

In the $3 \mathrm{~d}$ year of Shoho (I643-I647) Inouye Geki presented a treatise on firearms, in which he urged vehemently the pressing necessity of improving weapons. In the $3 \mathrm{~d}$ year of Keian (I650) Hojo Masafusa investigated the siege tactics of the Dutch and the art of shooting and handling guns and small arms; and, presenting an essay on the result of his investigation, together with plans and specimens of machines and instruments, he persuaded the Shogun, his master, to start the work of manufacturing firearms. Thus the art of gun making began to be treated with due attention.

Although in the time above stated there were many persons who cared for gun making, it was not long before they began to lay aside their guns and to leave them to rust, when people were thoroughly accustomed to peace and cared to employ only such weapons as bows and arrows, hand guns, swords or spears, etc. But in the era of Kyoho (I 7 I 6-I 735) the Shogun Yoshimune, who was awake to the urgency of the times, ordered Aoki Kon-yo, Ogiu Sorai and some others to study Dutch books and to make a plan for the improvement of weapons, and engaged at the same time a Dutchman named Kaiser, who by the order of the Shogun made several guns which were called "Koppi-ho," "Ten-ho" (mortar) and 
"Kanon-ho" respectively. After the death of that Shogun, his scheme for improving weapons was abandoned; and most of the men who had some particular knowledge of gunnery, even those who were in permanent homage to the Shogun as a teacher of gunnery, endeavored to keep their knowledge from the public, though such knowledge was nothing more than the ancient idea neither improved nor increased since it was first imported by Dutchmen, and they never intended to learn or discover any new thing. This state of things lasted for some time after the death of Yoshimune, and both gunnery and gun making diminished rather than advanced during the same period.

Since from the middle of the eighteenth century warships of Great Britain, France and Russia came frequently to visit this country, people who felt uneasy as to the fate of their country began to pay much attention to the means of defense and many of them sought eagerly to learn the military affairs of Western nations from Dutchmen who were then dwelling in this country, notwithstanding the fact that the government of the Shogun would hardly grant them license to have intercourse with foreigners. In the era of Temmei (I78I-I788) a retainer of the Sendai clan, named Hayashi Shihei, published a book entitled Kaikoku-IIeidan ${ }^{1}$ in which he argued strongly the urgency of the defense of the country and proposed a design for the purpose, extending the treatise to the topic of firearms manufacture and also to that of tactics. Moreover, in the same work the author exposed the fault of the policy adopted theretofore by the government in seeking a false peace for a time only, and advised the latter to take steps to correct the error. During the era of Anei (I 772-1780) the author, being enlightened previous to the publication of his elaborate work upon the necessity of guns for the national defense, contrived to make a wooden gun, and he was compelled to use in the firing practice the old gunpowder produced in the era of Genna about one hundred and fifty years before, for it was the only kind he could find in the country. This fact, evidencing the utter neglect during this period of the most effectual

${ }^{1}$ A Treatise on the Military Affairs of the Insular Country. 
weapon for the national defense, proves most clearly the wisdom of the author's opinion. Soon after the vehement argument of Hayashi Shihei was made public, difficulties frequently occurred in the international relations with foreign countries, as had been prophesied by him. In the $4^{\text {th }}$ year of Bunkwa (I 807) a Russian war vessel came to Etorop Island, Yezo, and landed her men forcibly on the island, and in the next year a British ship threatened the citizens of Nagasaki. The peaceful nation began to feel gradually the peril of foreign warships. Every clan was ordered to prepare for the defense of the country, and the arms making industry was stimulated to make a considerable advance. Almost all the guns made during this era (I804-I8I7) were of small (1830-r843) muzzle and forged with bronze. In the era of Tempo, Takashima Shirodayu, who made himself quite a master of gunnery, studied also the art of gun making, examining several different guns which he purchased from a Dutchman. From this time the art made constant progress, and the rate of progress was much celebrated after the era of Kaei (I848-I853), when the government bought many guns of Dutch form and encouraged the manufacture of firearms; and then all "Han" (or clans) commenced the work of gun making, using as a model those Dutch guns of the government, especially the two "Han," Hizen and Satsuma, embracing more advanced ideas than the rest, effected a most conspicuous development of the work. The number of guns made in the factories of both the government and the "Han" in about a year's time, from the first day of June of the 6th year of Kaei to the end of the following June, was $\mathbf{r}, 374$. The progress of domestic gun making was so remarkable that even in the years of Bunkyu and Gwanji (186r-1864) a considerable number of large guns made in the country was to be found mixed with foreign ones in their batteries. The large guns of those days included such as the following: a cannon, the shell of which weighed I2 pounds, I 8 pounds, or 24 pounds; a short cannon, the shell of which weighed 30 pounds, 80 pounds, or 150 pounds; and a mortar which measured 2 feet and 10.74 inches, or I foot and 11.96 inches. 


\section{Rifled Guns}

(a) Muzzle-Loading Guns.- The first time a rifled gun came into use in Japan was the Ist year of the era of Gwanji (I 864). Prompted by the necessity of national defense, the Shogunate Government issued orders for the manufacture of 40 4pound mountain guns and the purchase of a number of I2pound hexagonal guns of wrought iron; and later, on discovering the powerfulness of rifled guns, it urged the manufacture of $164^{\frac{1}{2}}$-pound French rifled guns (field guns). Among the guns made in those times, there was a 150 -pound bronze rifled cannon as large as 15 feet 0.5 inch long in gun barrel and 10.7 inches in caliber, cast by the Mito clan. The gun had eight riflings and was to be loaded with studded shells. In that way the first rifled guns were produced in this country.

In the Ist year of Keio (I865), work was started on some 30-pound French short cannon and I2-pound cannon; also the work of economically supplying improved guns by remodelling and rifling the old 24-pound guns was begun. Next year (I866), some ten or more French officers, commissioned and non-commissioned, were engaged, and under their guidance troops were newly organized and the system of military education was reformed; also a reform was made in the arms manufacturing, and the French methods were adopted where the Dutch had been in use.

(b) Breech-Loading Guns.-For a long time after the old breech-loading guns from France came to Japan, no attention was paid to the study of a breech-loading gun, and it was not until the eras of Gwanji and Keio (I864-I867), when some breech-loading guns of nineteenth century invention were for the first time imported, followed by a further importation of some 20-pound Armstrong guns (I Keio or I 865), that people began to pay attention to the study of its manufacture.

\section{Ammunition}

The manufacture of ammunition made gradual development side by side with the manufacture of small arms and guns. For small arms lead balls were used in the case of those 
early small arms like the "Tanegashima" tsutsu, but for later small arms cylindrical lead bullets with a conical head were used exclusively. As for guns, solid lead shells were in use in those earlier days after the introduction of guns into this country, but afterward in addition to the lead ones cast iron shells were made and used. The use of cast iron shells in those days was for the purpose of making up the shortage in the supply of shells caused by the high price of lead. Besides these shells, stone and earthen ones were used where shooting was done with wooden or paper guns, which once existed.

The manufacture of shells began suddenly to develop, when during the era of Tempo (I830-I843) investigations were made in the art and method of shell making, and some of the first shells were produced by the hand of Egawa Tarozaemon. Shells made at that time were spherical and commonly of cast iron, and they were already classified into two distinctive kinds, the solid shell and the explosive shell. These shells were widely manufactured up to the beginning of the era of Meiji.

Gunpowder is another thing that came into use with the introduction of small arms. Since this article could be manufactured more simply than other arms or ammunition and its materials were obtainable anywhere in the country, its manufacture soon spread among the people, until afterward it was produced at every point of the Empire. Thus before the Restoration every feudal clan engaged in its manufacture, and the amount so produced, together with that produced by private manufacture, reached an enormous figure.

\section{WARSHIPS}

The first foreign warship that came to Japan was a British one which called at her ports in August of the $5^{\text {th }}$ year of Bunkwa (I808). Down to the eras of Kokwa and Kaei (I844I 853) Japan's shores were yearly visited by Dutch warships and other European and American ships and war vessels, until in the 6th year of Kaei (I 853) a fleet of American warships entered Uraga and presented its credentials. This last event 
threw the country into heated discussions, and people agitated the question of coast defense. In September the Shogunate Government, which had become aware of the impracticability of the old law and had already been busily engaged in the construction of batteries and the improvement of arms, at last released the nation from the interdict which had been strictly observed for many years past against building large ships. The release once ordered, talk of warship building became very prevalent and people became deeply interested in that business. The next year (I Ansei or I854), in May, a two masted ship of 132 feet in length and 30 feet in breadth was built at the port of Uraga after the model of an English ship. About the same time three three-masted sailing ships were built in the province of Satsuma, and another ship of European style at Etchujima, Yedo, the latter under the command and supervision of the family of the Lord of Mito. These were the first ships built in imitation of European models. Previous to this, in June of the 9 th year of Tempo (I838), an attempt had been made by Lord Rekko of Mito to build a warship, named Hitachi Maru (I44 feet in length and more than 38 feet in breadth) of European design, and a plan was prepared by his near attendants, but, the idea not being approved by the Shogunate Government, it had to be abandoned.

These new ships, however, were European only in external ornamentation, and were either frail in build or low in speed, or both, and therefore not fit for practical service. Moreover, they were not perfect in the adjustment of draught and in the position of the center of gravity, and therefore liable to be overturned in case of stormy weather. But, on the other hand, very great benefits were derived from the building of these ships. Many faults likely to occur in shipbuilding were learned, together with the truth that shipbuilding is never an easy work, all of which went to awaken the people to the necessity of study of the art and open the way for future improvements of ships.

On the fourth of November, I Ansei (I854), tidal waves 
occurred near the port of Shimoda, which damaged the bottom of a Russian warship, the frigate Diana, just then anchoring at the port. At that time there was war in Crimea, and British warships were patrolling the Oriental ports, threatening to attack Russian warships. This obliged the damaged Russian warship to ask the Japanese Government for permission to enter Heta, another good anchorage in the neighborhood, for repairs, which she did, in order speedily to quit these seas for the north. The peimission was granted, but on her way to Heta water entered the break, and she sank off the coast of Misaki in Izu Province. Then the Russians decided to build a new warship and asked the government to collect for them the necessary materials and forces of blacksmiths and shipbuilders, which the latter agreed to do. The Russians, captain and all, engaged in the work, while teaching the Japanese workmen how to build ships. They urged the men on day and night, and, making quick progress, at last succeeded in finishing two schooners, and sailed away with these ships to the north. A misfortune as it was to the Russians, it brought on the contrary a good deal of fortune to Japan. During the progress of the shipbuilding the various artisans and mechanics engaged in the work studied much of the European methods from the work they actually did, though not without experiencing some hardships, and thus gained an opportunity of developing the building of ships of European style in this country, to their great advantage. After this time ships built by this method were styled "Kimizawa," the Kimizawa No. I, No. 2 and No. 3 being built gradually. A short time afterward, Russia, in acknowledgment of her gratitude, sent back to Japan those ships which her sailors had built in this country, at the same time presenting her with those fifty-two guns that the Russian warship had taken ashore when shipwrecked at Shimoda. This, facilitating the study of the manufacture of guns and war vessels, was a great addition to the benefits already gained from the misadventure of the Russian warship.

In speaking of the development of the Japanese Navy, we 
must refer to the fact that it owed much to the friendly advice that the King of Holland tendered to the Japanese Government to requite the favor he had received from this country by his many years' friendship with her.

On the second of July, 7 Kaei (or I Ansei, as the name of the year was changed, 1854), the Dutch Consul Donker Curtius, who was resident in Nagasaki, sent a letter to the Japanese Gorermment, minutely explaining the state of foreign countries and warning them of the pressing need of the defense of the country. This, aided by repeated arguments made upon a similar prohlem by Captain G. Favius of the Dutch warship Soembing, finally moxed the gorernment and led to its future decision of organizing a new nary. That matter also gave rise to the following arents. About the same time, the gorernment had placed an order with Holland for a certain number of ships, but it was found that, owing to a war (the Crimean Var) having broken out just then in Europe, ships were to be treated as cont raband of war and were not allowed to be exported. Inder the circumstanecs, Holland proposed that she would rather help this country build the ships herself. So she sent twenty or more of her officers and other subjects orer to this country to take up residence and stay as teachers, and even went so far as to present this country with the ship Soembing. Thereupon the government decided to appoint Yatabori Age and Katsu Rintaro to receive instruction.

In Octolure, 2 Ansei (I855), the Nagasaki Naral Training School wis established, in which a Dutch naval officer Perslecken and twenty-one others under him were instructors, and the soidiers of the Tokugawa Shogunate and clans, Yatahori kigezo and others of lower rank, were the scholars, among whom were most of those who later proved themselves to be important Japanese naval men (officers and the like) at the time of the Restoration of Meiji.

In 3 Ansci ( 1856 ), for the purpose of practice in naval construction (warship-building), a cutter was laid, which is said to have been completed for more than 2,000 ryo (the unit of the old moncy in Japan, I $r y^{\prime} o$ at about $\$ 3-\$ 5$ ), in one year's time. 
In April, 4 Ansei (1 857), the Warship Training School was founded in the military school at Tsukiji, Yedo. In August of the same year the Yappan (afterwards called the Kanrinkan), a three masted steamship that had been ordered from Holland, arrived at port. As to new instructors for naval training, thirty-seven persons, a number of Dutch officers and other men under them were on board, and in September the old instructors started home from Nagasaki by a merchantman.

In October, 4 Ansei (I 857), for the purpose of repairing ships and making and repairing naval arms, iron works were established at Aginoura, in the port of Nagasaki. The charge of the construction of the plan was put principally in the hands of Hardes, a Dutch naval engineer, who completed it in April, I Bunkyu (I86I). Steam engines, cupolas for iron and other implements and machinery provided in the iron works were wholly purchased of Holland. The expenses for all these amounted to about 50,000 ryo. The establishment of these works was not only for domestic purposes, but also for taking foreign orders, at the same time using them as an organ for selling coal, and, by so doing, enabling them to pay off the past fixed capital and meet the future expenditures with the profits to be obtained. Thus a very economical plan was adopted.

In May, 5 Ansei (I858), the Yedo arrived at Nagasaki, a three masted steam war vessel of the same type as the Kanrin$k a n$, and afterwards named the $C h \bar{o}-y \bar{o}-k a n$, the order for which had been given to Holland in the previous year.

In July of this year, four English war vessels entered Shinagawa Bay, Yedo, among which the steam yacht Emperor, afterwards named the Ban-ryu-kan, was presented as a gift to the Shogunate. Immediately after the receipt of this ship by the Shogunate, the other ships left for Nagasaki. In February, 6 Ansei (I 859), an order for a temporary closing of the Naval Training Institute having been issued by the Shogunate, the Dutch teachers left Nagasaki for home, and so the naval training at Nagasaki came to an end.

In January, 7 Ansei (I860), Japan dispatched the Kanrinkan to the United States of America, so it was the pioneer among 
ships dispatched to Europe or America by Japan in the name of the government. The purpose of the dispatch was to inspect the foreign (Western) conditions in general and to study the arts of navigation and shipbuilding. In November, 3 Bunkyu (i 863), an English ship Shunly (built in Glasgow, $463^{\prime} 35$ tons) was purchased for I, 000,000 silver pieces. In April, 3 Bunkyu (1863), the construction of the Naval Factory and Dockyard at the village of Kobe (the present City of Kobe) in Settsu Province was started, but the scheme was abandoned in November of the following year, owing to the recall to Yedo of Katsu Rintaro, the specially appointed officer for the work.

In November, I Gwanji (I 864), the government devised a plan to give to the French ambassador, Léon Roches, the charge of the design of the works, and according to it to establish a naval dockyard at Yokosuka and also a naval workshop at Yokohama to do preparatory work for the dockyard. This was the beginning of the present Yokosuka Naval Dockyard. The details of the construction of these plans as announced in January of the following year, I Keio (1865), were in brief as follows:

First, to set up a workshop at Yokohama that should make it its aim to repair ships and to give training in mechanical work. The estimate of the expenses of the construction was $\$ 2,400$,000; the term of completion, four years; the workshop to consist of the iron tempering mill, casting mill, pattern-making mill, lathe-making mill, fittings shop and timber works. The factory was to be set up entirely according to European industrial style; the instructors to be French naval engineers and men under them; and as pupils for the first term Ioo persons, the most efficient in Japanese industrial works, were to be selected. Implements and machinery needed by the workshops were to be purchased of France, the estimated total cost of which was 2,200,000 francs; however, materials needed in the works were to be adopted from as many of the domestic products as served the purpose, provided the prices did not exceed those for foreign products. The 
buildings to be constructed and attached to the factory were an iron foundry, two docks (large and small), three shipyards, armories, offices, waiting rooms for the workmen, etc. In February, I Keio (I865), the construction of the Yokohama Iron Works was commenced. In May of this year, the Shogunate sent Shibata Hyuga-no-kami to France on a mission to buy various kinds of machinery. In September the construction of the Yokosuka Iron Works was begun. In December Shibata Hyuga-no-kami returned from Europe, having performed his mission to England and France, with his suite and some French employes who had been engaged.

Work on the construction of the iron works of Yokohama and Yokosuka was pushed day and night and made very rapid progress. According to investigations in October, 2 Keio (I866), the foreign employes in service in the construction works numbered as many as forty-six. The two works were named the Japanese Naval Iron Works of Yokohama and the Japanese Naval Iron Works of Yokosuka.

In January, 2 Keio (I866), four officers and men were engaged out of the crew of the French war vessel Guerriere, and were put in charge of naval training on board the $F u j i$, of the Japanese Navy. Next year, in October, 3 Keio (1867), a change was made from French teachers to English, and some English naval officers and warrant officers were engaged to give instruction in naval training. In this year the government made some foreign shipwrights living in Yokohama manufacture boats and ship tackles as models for similar manufactures in Japan.

In October, 3 Keio (I867), the Shogunate restored to the Emperor the administration of the national government, which was followed by a civil war; consequently, the naval training was closed in February of the next year, and this caused Katsu Rintaro to request the French and English instructors to cancel their contracts by announcing to them the internal situation; and it finally came about that those foreigners left this country for home and the work of training was entirely abandoned. As hitherto mentioned, since her with- 
drawal of the restriction on shipbuilding (September, $6 \mathrm{Kaei}$, I853), Japan had seen the time gradually become ripe for her own warships to be built by herself, and consequently in May, 5 Ansei (I 854), the Shogunate built the ship Hoo-maru, in imitation of the European style, in the port of Uraga, Sagami; also a second one, the Shohei-maru, in the clan of Kagoshima, Satsuma. To the second, was added in June, 2 Ansei (1855), a war vessel Kwanko-kan, presented by Holland as a gift; and people, having for the first time been eye witnesses of the skilfulness and exquisiteness of the steam engine, were now so enthusiastic about the work that they sought eagerly for new knowledge of the art and practice in the ways of management. Besides, things were moving toward such a state of conditions that coast defense should not be neglected even a moment, that is to say, as the occasional opening of ports to foreigners threatened to result in a succession of domestic troubles and external disasters one after another, the Shogunate gave orders to the clans to prepare ships against any emergency. Upon this, the clans strove with one another in building or importing large ships. Of the great number of war vessels and ships for military service of European style thus gathered by the Shogunate and clans in the fifteen years from I Ansei (I 854) to 4 Keio (or I Meiji, I 868), only the part that can be found in the records reached a large total as follows:

(I) Nine war vessels owned by the government: 2 presented by the Dutch King and British Queen, I each; 7 bought for $\$ \mathrm{I}, 350,000 ; 4$ were built in Holland, I in England, 3 in the United States, and I in Germany.

Thirty-six military ships: I I built in Japan (I at Uraga, 3 at Kagoshima, 2 at Ishikawa-Jima, I at Shimoda, 2 at Nagasaki, 2 at Hakodate); I4 built in England, ro in the United States, and $I$ in Germany. The cost of the II built in Japan and I built in England is not known. The 24 others cost $\$ 1,806,000$.

The total is 45 ships. The cost of the 33 mentioned above is $\$ 3,336,000$. 
(2) Ninety-three military ships owned by the clans: I4 built in Japan, 57 in England, I7 in the United States, I in France, 2 in Holland, and 2 others, the place of building unknown. The cost of the 14 built in Japan and 12 built in other countries is not known; the remaining 67 cost $\$ 4,494$, ooo and 8 , Ioo ryo. (The last price is for one ship bought by the Uwajima clan.)

The grand total is 138 ships.

Of these ships the first steamer built entirely by the Japanese was the Chiyodagata: work begun in May, 2 Bunkyu (I 862), at Ishikawa-Jima, Yedo, launched in July, 3 Bunkyu (I863), and completed in May, 2 Keio (I866). Thus it took four years from the start to the completion of work. The reason was that in the course of the work the man in charge often left on a journey and each time the work had to be suspended. It is said that the expenses for the warship amounted to about 70,000 yen. It may be remarked again that the ship was the first one that was completed by Japanese by their own design and labor.

The following table shows some particulars of the ships built after European style at domestic yards previous to the Restoration: 

MILITARY INDUSTRIES: HISTORICAL SURVEY

Ships of Domestic Manufacture Owned by the Shogunate

\begin{tabular}{|c|c|c|c|c|c|}
\hline $\begin{array}{l}\text { Name of } \\
\text { Ship }\end{array}$ & Style & $\begin{array}{l}\text { Breadth and } \\
\text { Length }\end{array}$ & $\begin{array}{c}\text { Koku } \\
\text { (Japanese } \\
\text { Tonnage) } \\
\text { or h. p. }\end{array}$ & $\begin{array}{l}\text { Date of } \\
\text { Construc- } \\
\text { tion }\end{array}$ & $\begin{array}{l}\text { Place of } \\
\text { Construc- } \\
\text { tion }\end{array}$ \\
\hline Ho-o-maru. . & Bark & $\ldots$ & $\ldots$ & $\begin{array}{l}\text { May, } \\
\text { I Ánsei } \\
\text { (I } 854)\end{array}$ & $\begin{array}{l}\text { Uraga, } \\
\text { Sagami } \\
\text { Province }\end{array}$ \\
\hline $\begin{array}{c}\text { Shohei-maru } \\
\text { maru..... }\end{array}$ & “" & $\begin{array}{l}\text { Length Io ken } \\
\text { (6o ft.) } \\
\text { Breadth } 4 \text { ken } \\
(24 \mathrm{ft} .) \\
\text { Depth } 3 \text { ken } \\
\text { (I } 8 \mathrm{ft} \text {.) }\end{array}$ & $\ldots$ & I Ansei & $\begin{array}{l}\text { Kago- } \\
\text { shima, } \\
\text { Satsuma } \\
\text { Province }\end{array}$ \\
\hline Hozui-maru & “" & $\ldots$ & $\ldots$ & $\ldots$ & “ \\
\hline Taigen-maru & “ & $\ldots$ & $\ldots$ & $\ldots$ & “" \\
\hline $\begin{array}{c}\text { Kyokujitsu- } \\
\text { maru.... }\end{array}$ & “" & $\begin{array}{l}\text { Length } 23 \text { ken, } \\
\text { I shaku } \\
\text { (I } 39 \mathrm{ft} .) \\
\text { Breadth } 5 \text { ken, } \\
2 \text { shaku } \\
\text { (32 ft.) } \\
\text { Depth } 4 \text { ken } \\
\quad(24 \mathrm{ft} .)\end{array}$ & $\ldots$ & $3 \underset{(1856)}{\text { Ansei }}$ & $\begin{array}{l}\text { Ishikawa- } \\
\text { Jima, } \\
\text { Tokyo } \\
\text { City }\end{array}$ \\
\hline $\begin{array}{l}\text { Kimizawa- } \\
\text { gata.... }\end{array}$ & Schooner & $\ldots$ & & $\ldots$ & $\begin{array}{l}\text { Shimoda, } \\
\text { Idzu }\end{array}$ \\
\hline $\begin{array}{l}\text { Nagasaki- } \\
\text { gata...... }\end{array}$ & Cutter & $\begin{array}{l}\text { Length I2 ken } \\
\quad(72 \mathrm{ft} .) \\
\text { Breadth } 3 \text { ken } \\
\quad(\mathrm{I} 8 \mathrm{ft} .)\end{array}$ & $\ldots \ldots$ & $4 \underset{\text { (I } 857)}{\text { Ansei }}$ & Nagasaki \\
\hline $\begin{array}{c}\text { Hakodate- } \\
\text { maru.... }\end{array}$ & Schooner & $\begin{array}{l}\text { Length I } 8 \text { ken } \\
\quad \text { (Io8 ft.) } \\
\text { Breadth } 4 \text { ken } \\
\quad(24 \mathrm{ft} .)\end{array}$ & $\ldots$ & $\ldots$ & Hakodate \\
\hline $\begin{array}{l}\text { Kameda- } \\
\text { maru .... }\end{array}$ & “" & $\ldots$ & $\ldots$ & $\ldots$ & “ \\
\hline Sento-maru. & $\begin{array}{l}\text { Steam- } \\
\text { power, } \\
\text { screw } \\
\text { propel- } \\
\text { ler }\end{array}$ & $\ldots$ & $\ldots$ & $\ldots$ & Nagasaki \\
\hline $\begin{array}{c}\text { Chiyoda- } \\
\text { gata... }\end{array}$ & “" & $\begin{array}{l}\text { Length i } 7 k c n, \\
2 \text { shaku } \\
\text { (IO4 ft.) } \\
\text { Brealdth } 2 \frac{1}{2} k e n \\
\quad \text { ( } 5 \mathrm{ft} .)\end{array}$ & 60 h. p. & $\begin{array}{l}\text { Launched } \\
\text { in I } \\
\text { Gwanji } \\
\text { (I864) } \\
\text { Completed } \\
\text { in Dec., } 2 \\
\text { Keio } \\
\text { (I866) }\end{array}$ & $\begin{array}{l}\text { Ishikawa- } \\
\text { Jima, } \\
\text { Yedo } \\
\text { City }\end{array}$ \\
\hline
\end{tabular}


Ships of Domestic Manufacture Owned by the Clans

\begin{tabular}{|c|c|c|c|c|c|}
\hline $\begin{array}{l}\text { Name of } \\
\text { Ship }\end{array}$ & $\begin{array}{c}\text { Style } \\
\text { and } \\
\text { Material }\end{array}$ & $\begin{array}{l}\text { Breadth and } \\
\text { Length }\end{array}$ & $\begin{array}{c}\text { Koku } \\
\text { (Japanese } \\
\text { Tonnage) } \\
\text { or h. p. }\end{array}$ & $\begin{array}{l}\text { Date of } \\
\text { Construc- } \\
\text { tion }\end{array}$ & $\begin{array}{l}\text { Place of } \\
\text { Construc- } \\
\text { tion }\end{array}$ \\
\hline Kaisei-maru & $\begin{array}{l}\text { Schooner } \\
\text { Wooden }\end{array}$ & $\begin{array}{l}\text { Length i } 8 k e n, \\
2 \text { shaku } \\
\text { (I IO ft.) } \\
\text { Breadth } 4 k e n, \\
2 \text { shakul } \\
\text { (25 ft.) }\end{array}$ & $\ldots$ & $\begin{array}{c}\text { January, } \\
6 \text { Ansei } \\
\text { (1859) }\end{array}$ & $\begin{array}{l}\text { Sendai } \\
\text { Clan, } \\
\text { Samuk- } \\
\text { azezawa, } \\
\text { Oshu } \\
\text { Province }\end{array}$ \\
\hline $\begin{array}{c}\text { Shimpu- } \\
\text { maru.. }\end{array}$ & $\begin{array}{l}\text { Cutter } \\
\text { Wooden }\end{array}$ & $\begin{array}{l}\text { Length I } 2 \text { ken } \\
\quad(72 \mathrm{ft} .) \\
\text { Breadth } 3 \text { ken } \\
\text { (I8 ft.) } \\
\text { Depth } 2 \text { ken } \\
\quad \text { (12 ft.) }\end{array}$ & 50 h. p. & $\begin{array}{l}\text { April, } \\
5 \text { Ansei } \\
(1858)\end{array}$ & $\begin{array}{l}\text { Nagasaki, } \\
\text { Hizen } \\
\text { Clan }\end{array}$ \\
\hline Ryofu-maru & $\begin{array}{l}\text { Steam- } \\
\text { power, } \\
\text { paddle- } \\
\text { wheeled } \\
\text { Wooden }\end{array}$ & $\ldots$ & Io h. p. & $\begin{array}{r}\text { October, } \\
\text { I Keio } \\
\text { ( I } 865)\end{array}$ & $\begin{array}{l}\text { Saga, } \\
\text { Hizen } \\
\text { Clan }\end{array}$ \\
\hline Tsusai-maru & Schooner & $\ldots$ & . & .. & Awa Clan \\
\hline $\begin{array}{l}\text { Jimpu- } \\
\text { maru.. }\end{array}$ & $\begin{array}{r}\text { Schooner } \\
\text { Wooden }\end{array}$ & $\begin{array}{l}\text { Length i } 8 \text { ken } \\
\quad(\text { Io8 ft.) } \\
\text { Breadth } 5 \text { ken } \\
\text { (3o ft.) } \\
\text { Depth } 3 k e n, \\
4 \text { shakt. } \\
\text { (22 ft.) }\end{array}$ & & $5 \begin{array}{c}\text { Ansei } \\
\left(\text { I } 85^{8}\right)\end{array}$ & $\begin{array}{c}\text { Tsu, Tsu } \\
\text { Clan }\end{array}$ \\
\hline $\begin{array}{l}\text { Fukkai- } \\
\text { maru..... }\end{array}$ & $\begin{array}{l}\text { Schooner } \\
\text { Wooden }\end{array}$ & $\ldots$ & & $\ldots \ldots$ & Akita Clan \\
\hline Kosai-maru. & $\begin{array}{l}\text { Bark } \\
\text { Wooden }\end{array}$ & $\begin{array}{l}\text { Length } 17 \frac{1}{2} k e n \\
\text { (IO3 ft. } 6 \text { in.) } \\
\text { Breadth } 3 \text { ken, } \\
4 \text { shaku } \\
\text { (22 ft.) } \\
\text { Depth } 3 \text { ken } \\
\text { (I } 8 \mathrm{ft} \text { ) }\end{array}$ & $\ldots$ & $\ldots$ & $\begin{array}{c}\text { Matsuyama } \\
\text { Clan, } \\
\text { Shingu, } \\
\text { Kiii } \\
\text { Province } \\
\text { Himeii. }\end{array}$ \\
\hline $\begin{array}{l}\text { Hayatori- } \\
\text { maru..... }\end{array}$ & $\begin{array}{l}\text { Schooner } \\
\text { Wooden }\end{array}$ & $\begin{array}{l}\text { Length is ken } \\
\text { (90 ft.) } \\
\text { Breadth } 3 \text { ken }\end{array}$ & 450 koku & $\begin{array}{l}\text { June, } \\
5 \text { Ansei } \\
\left(\text { I } 85^{8}\right)\end{array}$ & $\begin{array}{l}\text { Himeji } \\
\text { Clan } \\
\text { Himeii }\end{array}$ \\
\hline $\begin{array}{c}\text { Kinkwa- } \\
\text { maru... }\end{array}$ & $\begin{array}{l}\text { Schooner } \\
\text { Wooden }\end{array}$ & $\begin{array}{l}\text { Length } 8 \text { ken } \\
\text { (48 ft.) } \\
\text { Breadth I ken } \\
\text { 4 shaku } \\
\text { (Io ft.) }\end{array}$ & Ioo koku & $\begin{array}{l}\text { June, } \\
6 \text { Ansei } \\
\text { (I859) }\end{array}$ & $\begin{array}{l}\text { Himeji } \\
\text { Clan }\end{array}$ \\
\hline
\end{tabular}


Ships of Domestic Manufacture Owned by the Clans-Continued

\begin{tabular}{|c|c|c|c|c|c|}
\hline $\begin{array}{l}\text { Name of } \\
\text { Ship }\end{array}$ & $\begin{array}{c}\text { Style } \\
\text { and } \\
\text { Material }\end{array}$ & $\begin{array}{l}\text { Breadth and } \\
\text { Length }\end{array}$ & $\begin{array}{c}\text { Koku } \\
\text { (Japanese } \\
\text { Tonnage) } \\
\text { or h. p. }\end{array}$ & $\begin{array}{l}\text { Date of } \\
\text { Construc- } \\
\text { tion }\end{array}$ & $\begin{array}{c}\text { Place of } \\
\text { Construc- } \\
\text { tion }\end{array}$ \\
\hline Ryujin-maru & “" & $\begin{array}{l}\text { Length } 6 \text { ken, } \\
4 \text { shaku } \\
\text { (Ioo ft.) } \\
\text { Breadth } 3 \text { ken, } \\
4 \text { shaku } \\
\text { (22 ft.) } \\
\text { Depth } 3 \text { ken, } \\
4 \text { shaku } \\
\text { (22 ft.) }\end{array}$ & $\ldots$ & $\ldots$ & $\begin{array}{l}\text { Shonai, } \\
\text { Shonai } \\
\text { Clan }\end{array}$ \\
\hline Jingo-maru . & “ & $\begin{array}{l}\text { Length i } 8 \text { ken } \\
\quad(108 \mathrm{ft} .) \\
\text { Breadth } 4 \text { ken } \\
\quad(2+\mathrm{ft} .)\end{array}$ & $\mathrm{I} 200 \mathrm{koku}$ & $\begin{array}{l}\text { June, } \\
3 \text { Bunkyu } \\
\text { (I } 863 \text { ) }\end{array}$ & $\begin{array}{l}\text { Himeji, } \\
\text { Himeji } \\
\text { Clan }\end{array}$ \\
\hline Ansai-maru. . & $\begin{array}{l}\text { Bark } \\
\text { WVooden }\end{array}$ & $\begin{array}{l}\text { Length } 21 \text { ken, } \\
\quad 4 \text { shaku } \\
\text { (130 ft.) } \\
\text { Breadth } 5 \text { ken, } \\
2 \text { shak } u \\
\quad(32 \mathrm{ft} .)\end{array}$ & 660 koku & $\begin{array}{l}\text { January, } \\
2 \text { Keio } \\
\text { (I 866) }\end{array}$ & $\begin{array}{l}\text { Aomori, } \\
\text { Oshu } \\
\text { Province, } \\
\text { Tsugaru } \\
\text { Clan }\end{array}$ \\
\hline Jimpu-maru. & $\begin{array}{l}\text { Schooner } \\
\text { Wooden }\end{array}$ & $\begin{array}{l}\text { Length i } 8 \text { ken, } \\
5 \text { shaku } \\
\text { (I I } 3 \mathrm{ft} \text {.) } \\
\text { Breadth } 4 \text { ken, } \\
\text { I shaku } \\
\text { (25 ft.) } \\
\text { Depth } 4 \text { ken } \\
\quad(24 \mathrm{ft} .)\end{array}$ & 800 koku & $\begin{array}{l}\text { January, } \\
3 \text { Bunkyu } \\
\text { (1 } 863 \text { ) }\end{array}$ & $\begin{array}{l}\text { Tomonot- } \\
\text { su, Bingo } \\
\text { Province, } \\
\text { Fuku- } \\
\text { yama } \\
\text { Clan }\end{array}$ \\
\hline$\overline{\text { Ono-maru } . . .}$ & “ & $\begin{array}{l}\text { Length i } 8 \text { ken } \\
\quad \text { (IO8 } \mathrm{ft} \text {.) } \\
\text { Breadth } 4 \text { ken } \\
\quad(24 \mathrm{ft} .) \\
\text { Depth } 3 \text { ken } \\
\quad \text { (I8 ft.) }\end{array}$ & $\cdots$ & $\ldots$ & $\begin{array}{c}\text { Doi, Ōno, } \\
\text { Echizen } \\
\text { Province }\end{array}$ \\
\hline
\end{tabular}

Total. .......................25 ships 


\section{CHAPTER II}

FROM THE RESTORATION TO THE SINO-JAPANESE WAR

The Restoration of the Imperial Government of Meiji was the greatest undertaking ever accomplished by the Japanese nation. On the one hand, it overturned the despotic military government that had existed for seven hundred years and brought back everything to the former conditions of the old days of the Imperial Government; while, on the other hand, it led to the abandonment of the national isolation policy adhered to for two hundred years by the Tokugawa Government, followed by friendly intercourse with Western countries, however far distant. Thus all branches of Western learning were introduced and the ways and manners of those countries widely adopted. So enthusiastically were these changes effected that in course of time a complete revolution took place here in Japan in the dominions of matter and mind. Among other things, the change in the institutions relating to the military system was so remarkable that arms and warships were entirely altered and there remained scarcely any vestige of them as they were in their old days. It is quite natural that all those changes should be made, in view of the condition of the Empire about the time of the Restoration, when arms and warships had an important bearing upon strategy, and any improvement or progress made therein was a very keen problem in the national defense of those days.

Although it was not merely a single reason but divers others that brought about the great Restoration of Meiji, the principal one was, as is evident from records of that time, that, when this country began intercourse with Western nations sometime before the Restoration, the people who actually observed the powerful and excellent arms and warships imported, recognized their wonderful power and felt alarm over the marvelous development, beyond their imagination, of Western countries, 
and at last being awakened from a long sleep, their minds took a new turn which led to the Restoration.

Thus the country was necessarily obliged to make improved arms and warships. But as the enormous amount of expense involved was an important problem for Japan in the economic conditions of that time, it was very difficult to fill the whole of the demands all at once. Much more so, as the gold and silver that had flowed out to foreign countries for twenty or thirty years before the Restoration, owing to the purchase of arms and ships, was now rising to such an enormous amount that the national Treasury was drying up by degrees and the finances after the Restoration gave more difficulty. In addition to this, the machine-making industry in Japan in those days was in a very primitive state, and there were found only two or three military factories established under the Shogunate that could be reckoned under the name of machine-making industry. As the leaders, engineers and workmen were all without much experience in the industry, there was no likelihood of the work being mastered and advanced. And, though fortunately some European countries had enough good will to send experienced officers and engineers and give every assistance in developing the military industry, and all of these efforts doubtless brought about ultimate advancement in the industries of this country at large, yet the difficulty was that, owing to the secrecy observed by every country in matters relating to military industry, it was almost impossible for the mechanical learner to get at the secret of the thing desired, as in the case of other industries. These facts retarded the industry very much.

This condition continued for rather a long time after the Restoration, and the development in military industry was all the slower. Under those circumstances, most of the goods required in the Japanese military system, especially arms and warships, which occupy the important places, for the period from the Restoration to the Sino-Japanese War, had to be bought from foreign markets.

A few years before the Sino-Japanese War, about the time 
that the Japanese constitution was promulgated, an advance in military industry gradually became noticeable, due to the tendency of the time, in which general progress in industry was being made, and also due to the improvement of the Imperial finances. In the following paragraphs will be found military industry and naval industry separately treated.

\section{INDUSTRIES OF THE ARMY}

The factories under the military administration in existence during the period between the Restoration of Meiji and the Sino-Japanese War were arsenals in Tokyo and Osaka, predecessors of the present ones, and the woolen cloth factory at Senju, Tokyo. The former was to manufacture and repair arms, ammunitions, ignition tools, implements, materials, etc., and the latter to manufacture woolen cloth used for military uniforms and other woolen goods also a part of the military outfit.

Of this latter factory enough will be written under the heading of "The Clothing Industry" in a subsequent chapter, and therefore we will not go further into this, but will give some account of the former ones here as our chief subject.

As was shown in the introduction, the manufacturing of arms, ammunition, ignition tools, etc., in Western style had its beginning before the Restoration, so that the predecessor of both the arsenals of Tokyo and Osaka succeeded the factory and the work performed by the Tokugawa Shogunate. After a good many alterations, abolitions, combinations and separations gone through in that transitional period at the beginning of the Meiji Era which extends from the old age over to the new, in October, I2 Meiji (I879), the Tokyo Arsenal and the Osaka Arsenal appeared, which had their business and working systems well arranged; and thenceforth to the time of the SinoJapanese War, some other reforms having been made, they saw their work gradually developing.

Before the development of the manufacturing of arms, ammunition and ignition tools is further mentioned, an outline of the history of each of the two arsenals running over the above 
period will now be presented under two subheadings, the Tokyo Arsenal and the Osaka Arsenal, each divided into three periods of time according to the changes undergone from the beginning of the work.

\section{ITeapon Factories}

(I) The Tokyo Arsenal and Its Predecessor. Period of the Arms Office and the Arsenal.-In January, I Meiji (IS68), naral and military sections were established which were changed in February to the Bureau of Military Affairs. In the intercalary April ${ }^{1}$ the bureau was closed, and an official of military affairs was appointed who took charge of the two bureaus of the army and nary and four offices of Fortification, Arms, Narships and Horses. The Arms Office was to administer the business relating to military arms and the nary, and to unify them. In order to collect arms it undertook the buying up of the factories for manufacturing or repairing arms that had hitherto been established by clans.

For this purpose, first of all, it bought up the Sekiguchi factory in Koishikawa. Tokyo, worked by the Tokugawa Shogunate, and set it to manufacturing arms as a government organ. This was the pioneer in manufacturing arms after the Restoration and at the same time the origin of the Tokyo Arsenal.

In Norember, 2 Meiji (I869), the Arms Office was closed, and in place of it the arsenal was established in February, 3 Meiji (I870). In October of the same year, some of the workshops of the Sekiguchi factory were moved partly to the site of the former high explosires mill inside of Takebashi Gate, and partly to that old place of Imperial inspection at Fukiage, and a part of the arms were manufactured in them.

In July; + Meiji (I8 7 I), the business office of the arsenal and the workshops inside of Takebashi Gate were moved to the grounds of the old mansion of the Mito clan on the outside of Koishikawa Gate, and the old buildings in the enclosure were used as working places and warehouses.

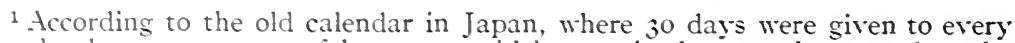
month, there was a sort of leap year which contained a month more than the common year. The month as such was called an intercalary month. 
In November of the same year, the training institute for small arms, which was the commencement of the education of the artillery artificers and the origin of the Artillery Artificer Training School was set up.

In July, 5 Meiji (1872), a sum of over 34,500 ryo was appropriated for building the small arms factory, and construction was immediately started.

After April, 4 Meiji (I87I), the manufacture of arms in the whole country was carried on under the sole management of the arsenal.

In August, 7 Meiji (I874), the ground of the Itabashi powder mill was settled upon.

In January, 8 Meiji (I875), a machine house for small arms and the heat tinting works were built.

Period of the Head Arsenal.-In February, 8 Meiji (I875), the régime of the arsenal was rerised and regulations for the Ordnance Committee and the head and branch arsenal were enacted; thereby the head arsenal of the First Ordnance Committee, chiefly in charge of the manufacturing and repairing of ignition tools, ammunition, other arms and materials was established in Tokyo.

The organization of the head arsenal was as follows:

$$
\text { Head Arsenal }\left\{\begin{aligned}
& \text { Head Office }\left\{\begin{array}{l}
\text { Head Bureau } \\
\text { Bureau of Examination } \\
\text { Bureau of Inspection of Material }
\end{array}\right. \\
& \text { Factories. } \begin{array}{l}
\text { Small arms works } \\
\text { High explosive mill } \\
\text { Saddle works } \\
\text { Timber works } \\
\text { Tempering works } \\
\text { Iron works }
\end{array} \\
& \text { Itabashi Factory Powder Mill }
\end{aligned}\right.
$$

In March, 8 Meiji (I 875), the powder mill in the Itabashi works was established.

In December of the same year, the drying place of mercuric fulminate was built in the head arsenal.

In June, 9 Meiji (I876), the small arms forge, the ammunition factory and the fire arrow factory were built in the head arsenal. 
In December of the same year, the equipment of the Itabashi powder mill was completed.

As the work in the high explosive mill increased owing to the Satsuma Rebellion in February, Io Meiji (1877), the machines for manufacturing in the high explosive mill were multiplied in the head arsenal. But as those were yet insufficient to fill the demand, a temporary high explosive mill was established on the Koishikawa parade ground (the site of the present Misakicho, Kanda).

The workmen employed in the head arsenal during the war exceeded five hundred a day, so that some extra female hands were engaged for the work, which marked the beginning of the employment of girls in military works in Japan. In June, the enlargement of all the mills in the arsenal was completed. In the same month, on account of the war, the quantity of the ammunition manufactured was so great that the magazines were feared to be too small to take it all in, and special powder magazines were built at Aoyama and Izumishinden. The number of powder mills was also increased in the Itabashi Branch Arsenal and some newly set up on the ground reserved for military use at Takinogawa.

In March, I I Meiji (I878), the Takinogawa Branch Bureau of the powder mill was established in the village of Takinogawa.

In I2 Meiji (I879), the finance law was revised, in which the arsenal expenses that had been treated under the General Account were removed to the Special Account as "Payment for Works." In September of the same year the work of manufacturing at the Takinogawa Branch Works was commenced.

Period of the Tokyo Arsenal.-In October, I2 Meiji (I879), arsenal regulations were enacted by which the head arsenal was closed and the Tokyo Arsenal was settled on that site, and the business of the old arsenal was divided into two parts, of which one was put under the charge of the Tokyo Arsenal, consisting principally of the manufacturing and repairing of arms and ammunition, and the other was put in charge of the headquarters of the first Ordnance Committee, consisting of the storing and distribution of arms. 
The organization of the Tokyo Arsenal at that time was as follows:

Tokyo Arsenal $\left\{\begin{array}{l}\text { Office of general management } \\ \text { Small arms mill } \\ \text { Ammunition factory } \\ \text { High explosive mill } \\ \text { Gun repairing mill } \\ \text { Powder mill } \\ \text { Department in charge of apprentices } \\ \text { Accountant's office }\end{array}\right.$

In the same month the preparatory work of the establishment of the Iwabana powder mill was started.

In March, I 3 Meiji (I880), ground for the same powder mill was purchased, and in May construction was commenced.

In August, I4 Meiji ( I 88I), the construction of the ammunition factory and the installation of the machinery were completed.

In October, I5 Meiji (I 882), manufacturing at the Iwabana powder mill was commenced.

In January, I6 Meiji (I883), the name of the powder mill attached to the Tokyo Arsenal was changed to the Itabashi powder mill.

In March, I 7 Meiji (I884), the arsenal regulations were revised and a part of the system of the organization of the arsenal was changed. The special change made was that the education of the apprentices that had hitherto been given in the arsenal was set apart from the system, afterwards to be given at a schoolhouse built separately.

In I 8 Meiji (I 885), the scale of the small arms mill, high explosive mill, etc., was enlarged.

In 19. Meiji (I886), the ammunition factory was enlarged and some newly designed machines were installed.

In April, 20 Meiji (I 887), the payment for the expenses of the arsenal, which, according to the method previously pursued, had in all cases been taken out of the expense account for works was discontinued, and thereafter all except the expenses needed directly for the works were defrayed out of the general expense account.

In November, the Itabashi powder mill was enlarged and adopted steam as its motive power by installing steam engines and boilers. 
In March, 22 Meiji (I889), the use in the army of the rifle of the old Murata type was discontinued and the magazine rifle of the Murata type was adopted, in consequence of which the system of the small arms mill of the Tokyo Arsenal was altered.

In March, 23 Meiji (I890), the finance law of military works was enacted, in which it was arranged that all fixed and working capital was to be given over to the arsenal and the expenses for the works were to be paid out of the income from the work account and miscellaneous income account thereof, that is to say, the law adopted a special account system.

In April of the same year, for financial reasons, a part of the gun repairing factory was closed and leased to the public.

In August of the same year, the arsenal regulations were revised, by which the name of the high explosive factory was changed to the ignition tools manufactory and the gun repairing factory to the factory for gun accessories.

In November, 24 Meiji (I89I), a part of the arsenal regulations was revised, in which the Meguro powder mill that had hitherto been under the jurisdiction of the Navy Department was removed to that of the War Department and attached to the Tokyo Arsenal; but, owing to the failure of the budget for the fiscal year of 25 Meiji ( 1892 ), it was not put under the new control until April of 26 Meiji ( I 893).

In May of 26 Meiji (1893), the factories for manufacturing gun cotton and smokeless powder were built in the Itabashi powder mill.

In December of the same year, the ignition tools manufactory in the arsenal was closed and its works were combined with the ammunition factory.

In the same month, in the manufactory for gun accessories a delicate instrument factory for manufacturing range finders, training gears and other field glasses was built under the guidance of an Italian major of artillery, Bracialini.

In April of 27 Meiji (I894), the gun cotton factory and the smokeless powder factory of the Itabashi powder mill were combined under the name of the third factory, and the 
Takinogawa branch was changed to the name of the Takinogawa powder mill.

(II) The Osaka Arsenal and Its Predecessor. The Period of the Arsenal and the Ordnance Factory.-In February of 3 Meiji (I870), the arsenal was established under the jurisdiction of the Military (Army and Navy) Department on the site of the rice granary in the inner citadel of the Osaka castle; machinery fitted up in the Nagasaki iron foundry that had been directed by the Tokugawa Shogunate, together with some of the workmen of the same foundry, were brought into service there, and in April business was begun, for which the old guard house within the Gate of Aoyaguchi of the Osaka castle was put to use as the provisional office; in June the arsenal was removed to the factory just built in the Osaka castle ground, and there the work was commenced. This was the origin of the Osaka Arsenal.

In February of 5 Meiji (I872), the name of the Osaka Arsenal was changed to the Ordnance Factory, its organization being as follows:

$$
\text { Ordnance Factory }\left\{\begin{array}{l}
\text { Accountant's office } \\
\text { Foundry } \\
\text { Forge } \\
\text { Lathing works } \\
\text { Leather ware works } \\
\text { Timber works }
\end{array}\right.
$$

The Period of the Branch Arsenal.-In February, 8 Meiji (I890), the regulations of the Ordnance Committee and the head and branch arsenal were enacted, by which the ordnance factory was given the new name of the branch arsenal, being organized as follows:

$$
\begin{aligned}
& \left\{\text { Head Bureau } \left\{\begin{array}{l}
\text { First Section (General Administration) } \\
\text { Second Section (Accounting) } \\
\text { Section of Construction }
\end{array}\right.\right. \\
& \text { Second Bureau }\{\text { Section of Inspection } \\
& \text { Branch Arsenal Copper gun foundry } \\
& \text { High explosive mill } \\
& \text { Saddle works } \\
& \text { Timber works } \\
& \text { Forge } \\
& \text { Kagoshima Branch Factory }\{\text { High explosive mill } \\
& \text { IVakayama Branch Factory-high explosive mill }
\end{aligned}
$$


At that time, the area of the grounds of these works and the connected grounds which were administered by the branch arsenal was above 276,00o tsubo (about 230 acres) in all, and above 12,900 tsubo (about II acres) of it was the lot for the buildings.

In October of the same year, for a certain administrative reason, the Wakayama branch factory was closed.

In November, 9 Meiji (1876), the management of accounts of the branch arsenal that had hitherto been under the charge of the paymasters of the Osaka garrison was changed, and an independent official was appointed in the branch arsenal.

As in February of 10 Meiji (I 877) the Satsuma Rebellion took place, the Hagi small arms factory was moved to the jurisdiction of the branch arsenal, where in addition to this more high explosive mills were built to make quickly small arms and ammunition.

The Period of the Osaka Arsenal.-In October, I2 Meiji (1879), the arsenal regulations were enacted, by which the Osaka Branch Arsenal was closed and the Osaka Arsenal was established, which was organized as follows:

$$
\text { Osaka Arsenal }\left\{\begin{array}{l}
\text { Section of general management } \\
\text { Gun works } \\
\text { Shot works } \\
\text { Vehicle works } \\
\text { High explosive mill } \\
\text { Small arms repairing works } \\
\text { Department of accounts }
\end{array}\right.
$$

The business relating to the storing and supply of arms which up to that time was that of the Osaka Branch Arsenal and the ordnance and powder magazines belonging to this business, together with the arms, ammunition, etc., stored in them, were then put under the jurisdiction of the head office of the second Ordnance Committee.

In January, I 5 Meiji ( 1884 ), the gun manufactory building, the construction of which was begun in 8 Meiji (I875), was completed, and in February the work of gun making was commenced.

In April of the same year, an institute for the examination of guns was established on the coast of Otsugawa in the Izumi 
Province and was named the Otsugawa Gun Examination Institute.

In June, I 7 Meiji (I884), the small arms repairing factory was closed and its works were combined with the vehicle works.

In September, work was started on an enlargement of the buildings of the gun works and the vehicle works.

In January, I8 Meiji (I 885), for the purpose of manufacturing shells for coast guns the shot works were enlarged.

In September, a railway was laid in the arsenal for the first time to facilitate the transportation of materials and manufactures.

In February, I9 Meiji (I 886), the construction of the works for making the gun carriage for coast guns was completed, and manufacture was at once begun.

In March, the Department of Accounts was closed, and the vice superintendent had charge of the accounting thereafter.

In January, 20 Meiji ( 1884 ), the shell lathing works were completed, and lathing work thereafter made great progress.

In January, 2I Meiji (r888), a laboratory was established which was perfectly equipped for all chemical experiments on materials, as qualitative analysis, quantitative analysis, etc.

In 22 Meiji (I889), a railway was laid connecting every factory and magazine in the enclosure to facilitate the storage of materials and manufactures and thereafter transportation became very easy.

In April, 23 Meiji (I890), the finance law for the military works took effect, and all incomes and expenditures of the arsenal were to be treated as special accounts.

In August, the arsenal regulations were revised, by which inspectors of manufactures were appointed and branch offices of the arsenal were established at the cities of Nagoia, Hiroshima and Kumamoto.

In November, 24 Meiji (I89I), another gun examination institute was established on the coast of Haruki, Izumi Province.

In December, 26 Meiji (I893), the arsenal regulations were revised by transferring the charge of inspection to the Depart- 
partment of Inspection, and the delicate instrument factory newly established was attached thereto.

The above is a rough account of the history of the Japanese military factories (excepting the Senju woolen cloth factory) for the period running from the Restoration of Meiji to the Sino-Japanese War. We shall next see how the manufacture of arms, ammunition and ignition tools was developed during the same period.

\section{Arms}

The history of the military factories in the early part of the era of Meiji is as stated above. As to the arms industry carried on in these factories during that time, the new government of Meiji established the Arms Office and worked on the plan of making the arms uniform by collecting under its control those arms-making and repairing establishments begun by the clans, and also devoting itself to the concentration of arms and machines. It was only the repairing and remodeling of small arms, and the manufacturing of harnesses, accessories to arms and simple cleaning implements that the military factories found to do during that time, and consequently the work done by these factories made little advance. Among the small arms that were in those years collected at the Sekiguchi manufactory administered by the arsenal, the arms which were of comparatively new types and preferred by clans much more than any others were the Gewehr, the Minie and the Enfield. The match-lock was not used much, as its ineffectiveness was known early in the latter days of the Shogunate, and, in using the rifle with firing mechanism, the clans were not slow in trying to get ahead of one another. Though the above three varieties of the rifle were muzzle-loading, they were furnished with firing mechanism. As these muskets mostly prevailed before the Restoration, not a few clans had their workmen imitate them; but, the art not being yet in an advanced state, there were only a few who had a thorough knowledge of manufacturing these muskets of new types, and it was especially difficult to find workmen skilled in it in those days of the Arms Office at the beginning of Meiji. In addition to 
this, the government of that time was devoting itself to the concentration and arrangement of the arms and factories in clans and could not engage in any other work. These are the reasons why the manufacture of these muskets could not yet find opportunity to develop. This is true not only for the infantry rifle, but also with the cavalry pistol and the carbine that were then already introduced, and also with the guns. As to the guns, most of them that were owned by clans toward the end of the Shogunate were smooth barreled and of domestic manufacture of dates before the era of Kyoho. But among those that were collected from clans by the Meiji Government there were also not a few guns of European manufacture purchased after the era of Tempo. Besides these, some guns of new types were also manufactured by the Shogunate and some powerful clans about the end of the Shogunate; and also some rifled guns were made at those domestic manufactories after their importation into Japan in the era of Gwanji. However, the guns manufactured in Japan were very imperfect; therefore it was necessary to look to foreign teachers for help, if any powerful gun serviceable for actual warfare was to be prepared. And here again as the Restoration of Meiji came, then the government's inability to divide its time with any business other than the one that was pressing it in those years made the matter the more difficult. Thus in the age of the Arms Office gun making in this country was left almost at a standstill and naturally guns in military use then, such as field, mountain, siege and fortress guns, were far from being uniform.

When in 3 Meiji (1870), the arsenal was established, the Enfield was adopted as the infantry musket, and next the 4-pound rifled gun of French type was adopted in the following year to organize some field artillery and mountain artillery battalions, and then the make of the guns was made uniform. Thus the preparations for arms manufacture by the military authorities was begun, the Tokyo Arsenal to make chiefly small arms, and the Osaka Arsenal chiefly guns.

In 3 Meiji (1870), Colonel Margritte and others were en- 
gaged as military teachers from France and were put in charge of the reformation of the military régime and also in charge of the training in arms making.

In June of the same year, work in forging, casting, lathing and pattern making was started at the arsenal in Osaka, which was at first chiefly engaged in the repairing of the existing arms and in preparation for making guns, vehicles, shots, ignition tools, etc. The expenditures of the arsenal in Osaka were then only I0,000 yen per month; coal for fuel was purchased of the navy; and for most of the other important materials they had to rely upon foreign countries. How defective the arrangement was at the time may be easily conjectured from these facts.

In October, 4 Meiji (I87I), Philippe Jauly, a Belgian foreman of small arms-making artificers, was engaged as a teacher of small arms making at the Tokyo Arsenal, and his services were continued until April, 8 Meiji (I875).

In February, 5 Meiji (1872), at the Osaka ordnance factory, for the first time a 4-pound mountain gun of French style was made, the copper used for it being wholly of domestic product.

In April, 5 Meiji (I 872), an artillery captain by the name of Lebon and four noncommissioned officers were engaged from France as teachers of industrial education, and in September Pironnet, a Belgian mechanical engineer, was engaged.

In April, 6 Meiji (I873), a set of machines needed for remodeling Enfield into Allumette was purchased for $\$ 20,000$.

In June of the same year, 4-pound field guns of French style were for the first time forged at the Osaka ordnance factory.

In July, 8 Meiji ( 1875 ), the wood working mill of the Tokyo Head Arsenal was furnished with hydraulic sawing and lathing machines, and also steam power was introduced for the big saws and planes, by which the cutting and planing works were started.

In September, Lemoine, a French caster, was engaged, who remained in charge until April, Io Meiji (1877).

In October, the casting mill of the Tokyo Head Arsenal was 
furnished with smelting furnaces, fitted up with machine fans, and steam grinding machines, which were used for breaking up earth and sand for molds, were fitted up. All of which were a great saving of labor in comparison with the method in use up to that time, and made quite a new phase in the industry.

In December, a French foreman of smiths by the name of Bacquet was engaged, who was in service until April, Io Meiji (1877).

In April, 9 Meiji (I876), the Itabashi powder mill began its work of powder making (for small arms). In July the small arms works in the Tokyo Head Arsenal manufactured rifles for the first time. In September, a riot arose in the Yamaguchi and Kumamoto prefectures, and the repairing of Snyders and Allumettes was hastily made.

In February, Io Meiji (I877), the Satsuma Rebellion broke out, and the Tokyo Head Arsenal made an extraordinary increase in workmen for making and repairing arms, and pushed the work day and night. As to the small arms, it was so arranged that the Enfields that were hitherto remodeled into Allumettes were made into Snyders during the war. The Osaka Branch Arsenal was also kept very busy in arms making for eight months until the rebellion was quelled in September, the workmen in all the factories continuing night work and devoting themselves to their duty with all their might and main. During this disturbance the Hagi small arms factory was put under the jurisdiction of the Osaka Branch Arsenal and the Allumettes were made there. All this work for the war, in which enormous quantities of arms were made and repaired, was accomplished so remarkably well that it contributed a great deal of study and experience to the military industry, putting it on a new path of progress and development.

In December, machinery for making coast and siege guns was purchased from Europe.

In January, I I Meiji (I878), drop hammer works were started in the musket works. In this year, the Satsuma Rebellion came to an end, and the damaged arms were repaired and the hand guns used in the war were changed to others. 
In October of the same year, selected pieces from among a lot of the old Enfields were remodeled into Snyders. The wood for the stock of the military rifle, of which there had been no particular kind fixed, was, as the consequence of study, decided for the future to be beech, walnut also being used. Also the lance for the cavalry was up to this time of no fixed make; therefore a system was arranged by which the old style lances were gradually changed to new style ones. In a word, in that year new arms were made or the old ones repaired according to the various improvements resulting from the experience obtained in the Satsuma Rebellion.

In March, 13 Meiji (I880), the Murata rifle made by Infantry Major Murata Tsuneyoshi from his own design was adopted as the military rifle of Japan. The Murata rifle, which was a great invention in the Japanese military industry, was not only the first small arms made in the new style from a Japanese design, but it was also the origin of all the domestic rifles made thereafter. In the same month work was started on remodeling Chassepot rifles into Muratas.

In February, I5 Meiji (I882), the manufacturing work of the ordnance factory in the Osaka Arsenal was started. In the same month, a bronze howitzer of 15 c.m., the first breechloading gun ever made in Japan, was cast.

In September, in the Osaka Arsenal the building of a duodecagonal reverberatory furnace was started, after the completion of which work was commenced in the making of the steel bronze gun by Japanese students who had studied abroad and had experience in making it with the furnace. Thus great progress in gun making took place in Japan.

In January, I6 Meiji (I 883), the pattern of the cavalry rifle was fixed. Thanks to the well arranged system of works in every one of its factories and the great progress made in the skill of its engineers and workmen since July of the previous year, the Tokyo Arsenal succeeded in that year in remodeling over 8,ooo Chassepots, and making over 7,ooo Murata rifles.

In January of the same year, in the Osaka Arsenal, barrels for the $7 \mathrm{c} . \mathrm{m}$. steel bronze mountain guns were made and in 
February carriage for the same; in April, the manufacture of steel bronze field guns and $12 \mathrm{c.m}$. steel bronze cannons was started, also in the same arsenal.

The manufacture of small arms in the Tokyo Arsenal in 17 Meiji (I884) increased in comparison with the former year, the producing power of rifles having now reached 30, ooo per year. That was due to the new arrangement of rifling the barrel in the arsenal and to its various machines being put in good order.

In April, I7 Meiji (I884), Italian Artillery Major Pompeio Grillo was engaged as a teacher in gun making.

In June, in the Osaka Arsenal the trial making of 19 c.m. and $24 \mathrm{c} . \mathrm{m}$. long cannons and $28 \mathrm{c.m}$. howitzers was started.

In September, Antonio Fornelis, an Italian engineer and Giacomo Hisso, an assistant engineer, were engaged.

In October, a steel bronze gun press, newly arrived from Europe, was fixed in its place.

In 18 Meiji (I885), some improvementswere made in the tail body, bayonet, etc., of the Murata rifle, and the new rifle was named the Murata rifle of the 18 th year style. The amount of arms made in that financial year was larger than in the year previous on account of the annually expanding armament, and the Murata rifles made in the Tokyo Arsenal exceeded 28,700 . In addition to this, the gradual improvement of the method of making arms and the skill of the officers, engineers and workmen made the progress of the work remarkably rapid, and consequently increased the amount of work done in a fixed number of hours in the day, while the defects and wastes in manufacture were lessened and naturally the rate of expenditure was reduced, resulting in the diminished cost of manufacture.

In January 19 c.m. frame gun-carriage cannons, in August $28 \mathrm{c} . \mathrm{m}$. frame gun-carriage howitzers and in December $24 \mathrm{c.m}$. frame gun-carriage mortars, all of cast iron, were cast for the first time in the Osaka Arsenal.

In the same arsenal, in February, I9 Meiji (I886), 24 c.m. frame gun-carriage cannons of cast iron, in May 15 c.m. steel 
bronze cannons and mortars, and in July 24 c.m. steel bronze mortars were cast, all for the first time.

In October, magazine rifles were manufactured and their testing was done in the Tokyo Arsenal.

In January, 20 Meiji (I887), I 9 c.m. and 24 c.m. cannons, and the carriages and stocks of the $28 \mathrm{c} . \mathrm{m}$. howitzers were made in the Osaka Arsenal.

In $2 \mathrm{I}$ Meiji (I888), the magazine rifle which had been in course of study was tested with satisfactory results, giving opportunity to the military rifle to make further advance, and thereupon the manufacture of the Murata simple rifle for military use was discontinued.

In April, Italian Artillery Major Pompeio Grillo, an instructor in the employment of Japan, and Antonio Fornelis, an engineer from the same country, were released from their offices owing to the termination of their contracts, and Alexandro Quaratezy, an artillery major of the same country, came as their successor.

In that year the Osaka Arsenal devoted itself to the making of coast guns and their accessories, and arranged the machinery for making more coast gun carriages, so that remarkable progress was effected in these works.

In March, 22 Meiji (I 887), the magazine rifle which was in the course of trial making was adopted as the military rifle and called the Murata magazine rifle, and from that time the rifle factory of the Tokyo Arsenal discontinued making the Murata simple rifle and was exclusively engaged in making the Murata magazine rifle. In the same year, the gun repairing works of the Tokyo Arsenal were engaged in manufacturing machinery for powder making and a large quantity of harness, and were kept very busy at that work.

In May, in the Osaka Arsenal the I 2 c.m. steel bronze cannon gun carriage was made for the first time. In the same year, this arsenal manufactured a large number of coast guns for use in the coast batteries which had been constructed one after another; this brought on a great development in gun making work. The most remarkable development made was 
the manufacture of the center pivots gun carriage for $24 \mathrm{c.m}$. cannon entirely of cast iron, when up to that time only frame gun carriages were made. In March, 23 Meiji (I890), the Osaka Arsenal cast a 19 c.m. short firing gun for the first time. In May, by altering the main part of the $24 \mathrm{c} . \mathrm{m}$. cannon, a more powerful one was manufactured at the same arsenal.

According to the investigations made in November of the same year, the guns of new models completed since the beginning of manufacturing were as follows, from which we can readily see what progress was then being made in this work:

Coast guns of every kind $\ldots \ldots \ldots \ldots \ldots \ldots \ldots \ldots \ldots \ldots \ldots \ldots \ldots \ldots$

Gun carriages for the above ...................... 76

Siege guns and garrison guns, together with their gun carriages.. 2

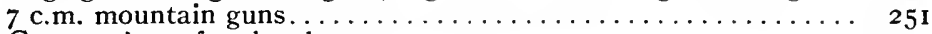

Gun carriages for the above..................... 277

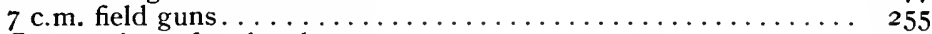

Gun carriages for the above ..................... 278

In July, 24 Meiji (189I), in the Osaka Arsenal 24 c.m. and $28 \mathrm{c} . \mathrm{m}$. short firing guns were cast for the first time.

In January, 25 Meiji (I 892), the Tokyo Arsenal made I, ooo small arms and Ioo sabers for the Military Department of the City of Melbourne, Australia, at its request, which was the beginning in Japan of the manufacture of articles made on commission for a foreign government.

In March, the Osaka Arsenal cast 9 c.m. cannons and quickfiring guns of the same caliber, actually showing rapid progress in gun making in Japan.

In August, the arsenal engaged an Italian artillery major by the name of Scipione Bracialini, under whom it made designs for the coast range finder, laying gear, field glass and models, and manufactured said articles.

In July, 26 Meiji (1893), the Osaka Arsenal, in compliance with the request of the governor of Manila, a Portuguese colony, made some $7 \mathrm{c} . \mathrm{m}$. mountain guns, which were the first guns made to order for any foreign country.

In the same year, the Tokyo Arsenal made a revolver called the revolver of the 26 th year model, on which much study and trial making had been expended.

As in 27 Meiji (1894) matters between China and Japan had 
been approaching a crisis, the business of the arsenal grew active, with an increase of materials and workmen, and of factories and machinery; and when at last the war commenced in June there ensued a great expansion of the military industry.

\section{Ammunition and Ignition Tools}

The beginning of the era of Meiji, in which the Arms Office was in control, was, as has been said in the section under "Arms," an age of construction in the history of the military industry; and the works carried on by the Arms Office in the making of ammunition and ignition tools in that period were only those of the old powder mills or high explosive mills which were passed over from the Shogunate and clans; the manufacture of supplies was mainly of ammunition used for the old rifle and was done on a small scale, as all the arrangements were defective. But the industry began to develop gradually when in 3 Meiji (1870) an arsenal was established and next the pattern of the arms for military use was fixed. In the following pages will be described the development of the industry after the establishment of the arsenal. At the time of the establishment of the arsenal in Tokyo in February, 3 Meiji ( 870 ), the bullets for the various kinds of rifle were made only as needed, but after the adoption of the Enfield in the same year as the regulation military rifle, bullets for the same rifle were chiefly made and those for others were made only as supplementary. The bullet adopted at that time was the cast oval bullet of lead.

In the same month the arsenal in Osaka was established. It commenced its work in June, and in the intercalary tenth month started its stuffing of gun powder and made frictional percussion caps, cartridges for the Chassepot, cartridges for maneuvers, fire arrows, etc., which was the first stuffing of gun powder done in the arsenal.

In November, 5 Meiji (I872), the ordnance factory in Osaka made for the first time the common shell and shrapnel for the four-pound mountain gun of French type. The pig 
iron and zinc plate used for them were entirely foreign. Shells used for guns of those days were generally those that were studded.

In February, 7 Meiji (I874), the ordnance factory made the common shell for the I2 c.m. mortar, in August the same for the 13 c.m. mortar and in December the Desmarets fuse for the four-pound mountain gun of French type, all for the first time.

In September, 8 Meiji (I 875), the machine for making the Snyder shell arrived at the Tokyo Head Arsenal from England, so that the arsenal made about 50,000 of the same shell daily.

In October, the same arsenal engaged Partray, a French foreman, as teacher in stuffing gun powder.

In April, 9 Meiji ( 1876 ), the manufacture of the rifle powder was commenced at the Itabashi powder mill.

In September, on account of the riots in the prefectures of Yamaguchi and Kumamoto, every powder mill was hastily put to the making of ammunition for the Snyder and Allumette, and in a few days' time a large amount was manufactured.

In February, Io Meiji (1877), as the Satsuma Rebellion broke out and the demand for ammunition for the Snyder had greatly increased, the powder mills of both the Tokyo Head Arsenal and Osaka Branch Arsenal increased their machinery; and besides, in Tokyo, a temporary high explosive mill was set up, by which a large amount of bullets and fire arrows for military use was made; while in the Osaka Branch Arsenal many a shell for the field and mountain guns was manufactured. As the manufacture of ammunition in this war needed to be done in great haste, it was carried on day and night, with the result that it amounted to a great quantity and consequently gave great advantage to the industry.

In April, Io Meiji ( 1877 ), the Itabashi powder mill made for the first time the big grain powder (for the gun), the powder No. I (for the gun), No. 2 (for the rifle), No. 3 (for the rifle) and the powder for the fuses.

In October, I I Meiji (I878), the method was fixed by which paper was to be pasted over with gum-lac within and without 
the small arms cartridge case; the shrapnel shell for the fourpound gun, which was previously made partly of wrought iron, was to be made in future of cast iron only. Besides, many improvements were made in the manufacture of ammunition and ignition tools, based upon the experience obtained from the Satsuma Rebellion.

In March, I3 Meiji (I880), a German by the name of Heer was engaged to give instruction in the manufacture of the cartridge case of the rifle.

In July, I4 Meiji (I88I), in the ammunition factory of the Tokyo Arsenal cartridges of the Murata magazine rifle were made on trial; in October the rolling work of bronze was begun by which the manufactures of the cartridge case and bronze for material (for making guns, etc.) was commenced, and in December, the brass plate was cast for the first time.

In January, I5 Meiji (I882), the pattern was fixed for the cartridge of the Murata rifle and in April its manufacture was begun in the Tokyo Arsenal.

In February of the same year, the Osaka Arsenal manufactured the common shell and shrapnel shell, both of a new pattern, for the 7 c.m. steel bronze field and mountain gun. At that time the muzzle-loading rifle was changed to the breechloading, and pressed shot was adopted as the pattern, which was a mantled shot made after the Krupp's, the mantle being of an alloy of lead and zinc.

In I6 Meiji (I883), considerable rearrangement in the work of cartridge making was made, and this, together with the fact that the employes were experienced in the work, brought up the amount of cartridges and blank cartridges of the Murata rifle manufactured to an enormous quantity.

In February, I6 Meiji (I883), in the Osaka Arsenal the time fuse and percussion for the $7 \mathrm{c} . \mathrm{m}$. steel bronze mountain guns were made; the former had a combustion range of 13 seconds and were the first compound fuses ever made in Japan. In April, the common shell and shrapnel for the 12 c.m. cannon were made for the first time.

In October, I 7 Meiji (I884), an annealing furnace for the 
cartridge case to be used in the ammunition factory was devised, which introduced the use of gas instead of the old charcoal.

In March, I 8 Meiji (I885), the black powder for mines was made for the first time at the Iwabana powder mill. This year, owing to the ever-progressing skill in the work in the ammunition factory, the experience in the casting and rolling of bronze as material for the cartridge case, and various improvements gradually made in all connections, the waste of the cartridge case in the manufacture greatly diminished, and the production was so rapidly increased that it amounted in the case of the cartridge case for the Murata rifle to above $4,400,000$, and in the case of the stuffing of cartridges and blank cartridges for the same rifle to above 4,040,000; also the percussion cap was hastily made on account of the large demand of the garrisons. Further, an increase was made over the previous year in the manufacture of the thin cartridge case, friction tube, cartridge bag of various guns, and the fuses of every kind, at the high explosive factory and in that of powder of every kind, the refining of niter and sulphur, and the making of charcoal, at the Itabashi powder mill. In the same year, the gun repairing mill of the Tokyo Arsenal made a satisfactory trial in casting the metal for the shrapnel for the $7 \frac{1}{2}$ c.m. Krupp gun by a combination of pig iron of domestic production. Besides, in the Itabashi powder mill, a powder adapted to the new $7 \mathrm{c} . \mathrm{m}$. field and mountain guns was made.

In August, I 8 Meiji (I 885), in the Osaka Arsenal the chillediron shell for the $28 \mathrm{c} . \mathrm{m}$. cast-iron howitzer with band, and common shell and chilled-iron shell for $29 \mathrm{c} . \mathrm{m}$. cast-iron cannon with band were made for the first time.

In this year, the use of the old mantled shells was discontinued, for they were imperfectly pressed and liable to explode, and the copper driving band was adopted in their place.

In October, I9 Meiji (I886), in the Iwabana powder mill the black powder for field and mountain guns was made for the first time.

In January, 20 Meiji (I 887), a shell-lathing shop was started 5 
in the Osaka Arsenal and the work in shell lathing therein was done much more speedily. In July, in the same arsenal, base fuses for the $19 \mathrm{c} . \mathrm{m} ., 2+\mathrm{c} . \mathrm{m}$. and $28 \mathrm{c.m}$. guns were made for the first time.

In 2I Meiji (I888), in the Osaka Arsenal, the machines for making shells for the coast guns and especially those for making fuses and driving bands were increased and so arranged that great progress was made in this work.

In 22 Meiji (I889), in the ammunition factory and the high explosive factory of the Tokyo Arsenal, the making of the ammunition for the Murata magazine rifle and ignition tools was begun. This year the high explosive factory began to try the making of smokeless powder.

In March, 23 Meiji (I890), four Korean students were sent to this country to study the art of the firing ordnance maker and entered the Tokyo Arsenal. They were the first foreign students sent there for such a purpose.

In August, at the Osaka Arsenal, a comparative test was made of the shells made of the Italian Gregorini cast iron and the Japanese cast iron of Kamaishi. The result clearly showed no difference in all qualities between the two shells, the Kamaishi iron having been proved to be good enough as a material for the shells.

According to the investigations made in November of the same year, the number of shells made in the Osaka Arsenal since the beginning of the manufacture of shells for the guns of the new pattern was as follows:

Shells for the various coast guns . . . . . . .

Shells for siege guns and garrison guns ............. $\quad 875$

Shells of all kinds for $7 \mathrm{c.m}$. field and mountain guns . . . . 370,756

Fuses of all kinds...................... 300,238

In September, 25 Meiji (I892), in the Tokyo Arsenal, the cartridges and blank cartridges for the Smith \& Wesson revolver were made for the first time.

In November, in the Osaka Arsenal, the 30-second compound fuse for the $2 \mathrm{c.m}$. cannon was made for the first time. The first compound fuse made in Japan was that for the $7 \mathrm{c}: \mathrm{m}$. 
gun, having a combustion range of $\mathrm{I} 3$ seconds; the second that of 30 seconds, which followed the Italian system, with some amendments, and adopted as the fuse for guns of medium caliber; and the third that of 50 seconds, which was made by taking the 30 -second fuse as its base and increasing the length of the fire channel to 50 seconds and weakening the resistance of the suspender of the detonator in time fuse so as to be acted upon by using even less powder than ever for the cartridge of the mortar.

In January, 26 Meiji (I893), in the Osaka Arsenal, the shrapnels for the $24 \mathrm{c} . \mathrm{m}$. cannon and for mortar were made for the first time.

In April of the same year, the Meguro powder mill attached to the Navy Department was put under the jurisdiction of the Tokyo Arsenal, and thereafter the charge of making a part of the powder used by the navy was taken by the arsenal. In that month the making of cartridges for the Murata magazine rifle was started. In July of the same year the making of ammunition for the $7 \mathrm{c} . \mathrm{m}$. mountain gun was started in compliance with the request of the governor of Manila, a Portuguese colony.

In May, 27 Meiji (I894), the Osaka Arsenal cast the chillediron shell for the 27 c.m. cannon. Just then the Sino-Japanese War was about to commence, and both the Tokyo and Osaka Arsenals were becoming busy, the making of ammunition and ignition tools especially showing the highest activity.

In May of the same year, the Itabashi powder mill started the making of niter and gun cotton.

In August of the same year, the use of common powder for the sheli burster was discontinued, and in its place the yellow powder made with improvement after study since 20 Meiji (I887) was adopted.

\section{INDUSTRIES OF THE NAVY}

The Japanese naval industry before the Restoration of Meiji was, as roughly described in the introduction, only in its initial stage. All necessary arrangements were far from being 
perfect in those days, when domestic troubles and external annoyances followed one another and threw obstacles in the way of the unification and progress of the industry, making the doings of the Shogunate and clans toward it very diverse. The factories administered by the Shogunate at the time of the Restoration were the Nagasaki Iron Works, the Yokosuka Naval Arsenal, the Uraga Dockyard, the Yokohama Factory, etc.; and the principal factories run by clans were the Ishikawa-Jima Dockyard, the Hyogo Iron Works, the Kagoshima Dockyard, etc. All these were started to build and repair warships and make guns for them. But of all the ships owned by the Shogunate and clans since the new establishment of the Japanese Navy (which were 20 warships and 95 ships for military use, I 5 in all), the greater part was purchased from foreign countries and only ten or so were built at domestic yards. Thus, though the naval industry before the Restoration served for laying the foundation for its future work and progress, it did no remarkable work in any direct manner. And when the war of the Restoration came, people were absorbed in warlike preparations, and such an affair as shipbuilding was entirely forgotten, so that the industry was brought to a sudden standstill. Consequently the work done in the four years between the Restoration and the establishment of the Navy Department, that is, in the four years under the administration of the Office of Military Affairs (from I Meiji, or 1868 , to July of the next year) and the administration of the Military and Navy Department (from July of 2 Meiji, or 1869 , to February of 5 Meiji, or I872) were insignificant. The only things done in the interval were that the name of the Ishikawa-Jima Dockyard was altered in July of 4 Meiji (187r) to Factory of the Shipbuilding Bureau, and later to Ship Administrative Bureau (Shusenryo); Hida-Hamagoro, who had just returned from abroad, where he went to inspect the condition of the shipbuilding industry some years before, was appointed chief of the bureau; in the yard some petty repairs (not fundamental repairing) of ships and the making of some small ships and tools were done; and further in the 
Yokosuka Naval Arsenal, the Uraga Dockyard, etc., work was continued as before. Thus in those periods there were no industrial achievements that should be specially reported. Therefore here will be mentioned only those after the establishment of the Navy Department in 5 Meiji (I872). To make the development of the naval industry clearly understood, it would be proper to treat the history of the expansion and construction of the factories separately from that of the development of the art of making ships and arms. For this reason an outline of that part of the history of the Japanese naval factories which runs from the establishment of the Navy Department to the Sino-Japanese War will be given before going on to describe the development of the shipbuilding industry.

\section{History of the Shipbuilding Factories}

(I) The Ishikawa-Jima Ship Administrative Bureau.-In 5 Meiji (I872) the Military and Navy Department was closed and the Navy Department was established, and as a consequence the Ishikawa-Jima Ship Administrative Bureau was brought under the jurisdiction of the Navy Department; but as afterwards, when the plan of the naval enlargement was completed, it was found that the working capacity of the bureau was insufficient for the required service, its work was transferred to the charge of the new yard in Yokosuka, and there being no longer any necessity for its existence as an independent establishment, in 9 Meiji (I 876) it was combined with the Tsukiji Arms Bureau with its machinery and buildings, and then the work of the government in Ishikawa-Jima entirely ceased.

(II) The Yokohama Factory.-It was established by the Shogunate in I Keio (I 865), was afterwards put under the jurisdiction of the Industrial Department of the Meiji Government, and in October of 5 Meiji (I 872) was brought under that of the Navy Department together with the Yokosuka Dockyard and attached to the Ship Administrative Bureau; but soon the jurisdiction was once more changed, and in December 
of the next year the factory was attached to the Finance Department.

(III) The Yokosuka Naval Arsenal.-In October, 5 Meiji (1872), the Yokosuka Dockyard, as the arsenal was called originally, was brought under the jurisdiction of the Navy Department from that of the Industrial Department and attached to the Ship Administrative Bureau. Daijo (a civil officer in the Navy, corresponding to captain in rank) AkamatsuNoriyoshi was the chief of the same dockyard, and the chief architect, Velny, took, as before, charge of all business relating to naval architecture at the head of the French employes. The Frenchmen employed were gradually superseded by Japanese until in Io Meiji (I877), the last of them having been dismissed, there were no foreigners remaining in the service.

In May, 22 Meiji (I889), the jurisdiction of the dockyard was changed, and it was newly named the Shipbuilding Division as a part of the Yokosuka Naval Station, consisting of the Designing Section and the Working Section.

(IV) The Onohama Dockyard (Branch of the Shipbuilding Division of the Kure Naval Station).-This was begun as a private yard by an Englishman named Kirby. In I6 Meiji (I883) the Navy Department ordered from it the warship Yamato to encourage domestic shipbuilding. Upon the laying of her keel, the department paid a part of the contract price in advance, on the security of the factory buildings and machinery therein contained. But as unfortunately Kirby died before he finished the work, the government doubted the possibility of the completion of the Yamato and bought up the yard according to the conditions of the contract. In January of I 7 Meiji (I884) the yard was named the Onohama Dockyard and put under the direct control of the Ship Administrative Bureau. The Kure Naval Station having been opened in July, 22 Meiji ( I889), the name of the dockyard was altered in March of the next year to the Onohama Branch Yard of the Shipbuilding Division of the Kure Naval.Station, and further in May, 26 Meiji (I893), to Branch of the Shipbuild- 
ing Division of the Kure Naval Station. In June, 28 Meiji (I 895), all the buildings, machinery, tools and other properties of the branch were transferred to the Kure Shipbuilding Division; which ended the naval shipbuilding work at Onohama.

Six warships and twelve torpedo boats were built at the yard after it was placed under the control of the government.

(V) The Kure Naval Arsenal.-The construction of the Kure Naval Arsenal was one of the works of the first expansion of the navy. In 22 Meiji (I889) the Kure Naval Station was opened and in the same year the construction of the Shipbuilding Division was started. In 24 Meiji (I 89I) the main factories were almost finished and in 28 Meiji (I 895) the construction was completed. While the construction work was going on, ships were built by the factories as rapidly as they were completed and ready for business.

(VI) The Sasebo Naval Arsenal.-Like the Kure Arsenal it was constructed as a work of the first expansion of the navy. In July, 22 Meiji (I889), the Sasebo Naval Station was opened. The construction of the Shipbuilding Division was started in 23 Meiji (I890) and completed in 30 Meiji (I897). While the construction was in progress, some shipbuilding was done at the factories as rapidly as they were completed. The general structure of the arsenal was not large, as it was mainly for repairing ships.

The above is an outline of the history of the naval factories that existed between the establishment of the Naval Department and the Sino-Japanese Var. In the following article the development of warship building will be roughly described.

\section{Warships}

When, in February, 5 Meiji (I872), the Navy Department was established, Japan had thirteen warships and four transports, seventeen in all, with a total tonnage of only I 3,832 ; of these only one, viz., the Ryujo exceeded 2,00o tons, and five, viz., the Azuma, the Tsukuba, the Fujiyama, the Kasuga and 
the Nisshin exceeded I,ooo tons. They were made of wood, except the armored Ryujo and Azuma, and the Moshun, a composite ship. Both the Seiki, a second-class gunboat of a displacement of 897 tons, and the Ishikawa, a training sailing vessel of 253 tons, were wooden. The keel of the former boat was laid in November, 6 Meiji (I 873), at the Yokosuka Arsenal, and she was completed on June 2I, 9 Meiji (I876), and the latter had her keel laid in August, 7 Meiji (I874), at the Ishikawa-Jima Dockyard, and was completed on July 2, 9 Meiji (I876). But as Japan is entirely surrounded by sea and knew that she could not rely on such ships in the defense of her coast, as early as the establishment of the Navy Department she made a plan to build warships of new models. According to the plan, in October, 5 Meiji (I872), the Yokosuka Dockyard that had belonged to the Department of Industry was attached to the Ship Administration Bureau under the jurisdiction of the Navy Department, and thereby being enlarged was put to the service of building some new warships. There the Jingei, a wooden Imperial yacht of a displacement of I,464 tons was started in September, 6 Meiji (I 873); then the above mentioned Seiki and Ishikawa, the Amagi, the Iwaki, the Kaimon and the Tenryu were built. The Amagi was a second-class gunboat of a displacement of 926 tons, the Iwaki a second-class gumboat of 656 tons, the Kaimon a coast defense ship of I,358 tons, and the Tenryu a coast defense ship of I, 547 tons. All of them were wooden three masted barks with single screw propellers and run by steam power. In I 3 Meiji (I880), the Tateyama, a sailing vessel for training, wooden, two masted and of the brig type, and of a displacement of 544 tons, was built in the Kawasaki Dockyard at Kobe.

After the establishment of the Navy Department eight years or more elapsed, and during this time the condition of things was completely changed. Wars and complications arose one after another, such as the expedition to Formosa, the Satsuma Rebellion, and the controversy between Japan and China, and in recent times rapid progress was made in the art of making arms and ships. In spite of these developments, 
the preparations of the navy were too slow to make any progress in the work of shipbuilding. Consequently the government decided upon a policy of naval construction which consisted in completing the work on a twenty years' plan. The plan was changed next year to one of eight years, and upon it an annual expenditure for naval construction of 3,330,000 yen was paid from I6 Meiji (I883), thus bringing about a new epoch in Japanese naval expansion. The following are the warships built in the five years from I6 Meiji (I883) to $2 \mathrm{I}$ Meiji (I888):

Cruisers: the Naniwa, the Takachiho, the Matsushima, the Itsukushima, the Chiyoda, the Hashidate.

Coast defense ships: the Katsuragi, the Takao, the Yamato, the Musashi.

Gunboats: the Chokai, the Tsukushi, the Atago, the Akagi, the Maya.

Dispatch boats: the Yaeyama, the Chishima.

Training ships: the Manju, the Kanju.

Total: I9 warships.

Of these, twelve were built at domestic yards, the Hashidate, the Katsuragi, the Takao, the Musashi, the Atago and the Yaeyama, at the Shipbuilding Division of the Yokosuka Naval Station; the Yamato, the Akagi, the Maya, the Manju, and the Kanju, at the Onohama Dockyard; and another one at the Ishikawa-Jima Dockyard. The type, displacement, horse power, speed, etc., of these ships are as shown above. The progress in the art of naval construction in Japan owes much to the building of these ships, which paved the way for the future building of a number of large ships. The above was the first naval expansion of the Empire.

The second naval expansion was begun in the fiscal year of 22 Meiji (I889), and the construction of the cruiser Akitsushima was started at the Yokosuka Shipbuilding Division, and that of the gunboat Oshima at the Onohama Dockyard, their displacement being 3, I 59 tons and 640 tons respectively. In March of the same year the gunboat Atago was completed, and in November the coast defense ship Takao. 
In March, 23 Meiji (1890), the despatch boat Yaeyama, and in August the gunboat Akagi were completed.

In 24 Meiji (I 89I) a plan was devised by which the secondclass cruiser Yoshino, the third-class cruiser Suma, and the despatch boat Tatsuta were to be built. Of these the Suma was to be built at a domestic yard, and in 25 Meiji (I 892) work was started at the Yokosuka Shipbuilding Division.

In March of the same year the gunboat Oshima was completed.

In 26 Meiji (I893) a plan was made to build the battleships Fuji and Yoshima and the despatch boat Miyako. The naval construction expenditure for those three ships, having been rejected in the second session of the Imperial Diet, was to be paid partlyby the Imperial household at the rate of 300,000 yen each year, partly out of the government officials' salaries, onetenth of which was set apart for the purpose; but in fact the building had been started already in 25 Meiji (I892). In the third session of the Diet the expenditure was approved and decided to be paid out of the national Treasury. One of the ships was built at a domestic yard; it was the Miyako. Her keel was laid in May, 27 Meiji (I894), a month before the Sino-Japanese War commenced, at the Kure Naval Shipbuilding Division, and it was the first warship constructed there.

The three warships in the plan of the 26 th fiscal year, the third cruiser Suma and the dispatch boat Tatsuta in that of the 24 th fiscal year were not completed before the Sino-Japanese War began in 27 Meiji ( 1894 ). Those of the ships in course of construction in this country that had been finished by that time were the second-class cruiser IIashidate and the thirdclass cruiser Akitsushima. Also the dispatch boat Tatsuta was brought out from England and took part in the war. The warships of the Japanese Navy that took part in this war were as follows:

Second-class battleship: the Fuso.

Second-class cruisers: the Hashidate, the Itsukushima, the Matsushima, the Yoshino, the Naniwa, the Takachiho.

Thircl-class cruisers: the Akitsushima, the Izumi, the Chiyoda. 
Third-class coast defense ships: the Tsukuba, the Takao, the Musashi, the Hiei, the Kongo, the Yamato, the Katsuragi, the Kaimon, the Tenryu.

First-class gunboat: the Tsukushi.

Second-class gunboats: the Amagi, the Oshima, the Akagi, the Chokai, the Maya, the Atago, the Iwaki.

Dispatch boats: the Yaeyama, the Tatsuta.

Total: 29 warships, 55,805 tons.

\section{Torpedo Boats ${ }^{1}$}

The first adoption of the torpedo boat by the Japanese Navy was in 13 Meiji (I880). She was the torpedo boat No. I, the parts of which were made by the Yarrow Company of England and put together at the Yokosuka Shipbuilding Division, and was of only 40 tons displacement, 430 actual horse power and r 4.38 knots speed.

In 17 Meiji ( 1884 ) the torpedo boats No. 2, No. 3 and No. 4 , also made by the Yarrow Company, were put together at the Yokosuka Shipbuilding Division.

Each of these boats was furnished with a locomotive boiler, and had no torpedo tube, but was provided at her stern with a cylindrical timber loaded with an explosive compound at its end, a contrivance to sink the enemy's ship by running the boat against her.

In 2 I Meiji (I888), at the Yokosuka Shipbuilding Division the building of the first-class armored torpedo boat Kotaka was finished. Her parts were made by the Yarrow Company of England. She had four torpedo tubes and two locomotive boilers.

In 23 Meiji (I890), there were begun, at the Onohama Branch Yard (the name was changed owing to reorganization) of the Shipbuilding Division of the Kure Naval Station, the building of boat No. 5 (hull and engine bought from the Creusot Company of France) and of boats Nos. 6 to 9 (hulls only bought from the same company); also the making of the engines for the boats Nos. 6 to 9, which was the beginning in Japan of engine making for torpedo boats. The design of the

\footnotetext{
${ }^{1}$ No submarine boats were in use in this period.
} 
main engines was: revolution, 335; horse power, 525 ; speed, 20 knots; single screwed, surface condensing and double expansion; the air pump and water pump workable by the main enyine. Of the five boats, Nos. 5 and 6 were finished in March, 25 Meiji (1892), and Nos. 7, 8 and 9 in April of the same year. They gave satisfactory results in their trial run, especially the engines of boat No. 6 showed, even though it was made first of all, as fair a speed as 19.236 knots. All of them were thirdclass torpedo boats.

In 25 Meiji (1892) torpedo boat No. Io was completed at the Onohama Branch Yard. She was the first torpedo boat built wholly by the Japanese Navy. In type she was the same as boat No. 5 built by the Creusot Company of France. She was launched in September, 24 Meiji (I89I), and completed in April, 25 Meiji (I892). Her construction was as follows:

Length: I Io feet $8 \frac{3}{4}$ inches.

Breadth (in the broadest part): I I feet $\frac{3}{8}$ inches.

Depth: 7 feet $\mathrm{I} \frac{9}{32}$ inches.

Draught (average) : 2 feet $\mathrm{I}_{\mathrm{I}} \frac{7}{16}$ inches.

Displacement: 52.9 tons.

Number of revolutions: 335 .

Actual horse power: 525 .

Speed: 20 knots.

Engine: single screwed, surface condensing, double expansion.

Boiler: a locomotive boiler made of bronze.

Rudder: $\mathrm{I}$.

Armament: one 47 m.m. light quick-firing gun, 2 torpedo tubes.

In 26 Meiji (1893), at the Onohama Branch Yard of the Shipbuilding Division (name changed for the second time) of the Kure Naval Station, the building of boats No. I2, No. I3, No. I4, No. I6, No. I7, No. I 8 and No. 20, whose hulls and engines were, except No. 20, the same as No. Io, was completed.

In the same year, the building of boats No. I5, No. 22 and 
No. 23 was completed at the same yard. Boat No. I5, made by the Normand Company, France, and launched in May, 25 Meiji (I892), was purchased as a model boat for those to be built in future. Boat No. 20 was built in imitation of No. 15. Her construction was as follows:

Length: I I f feet $6 \frac{19}{3} \frac{9}{2}$ inches.

Breadth (broadest part): I I feet $6 \frac{7}{3}$ inches.

Depth: 6 feet $6 \frac{3}{4}$ inches.

Draught (average): 2 feet I $\frac{7}{8}$ inches.

Displacement: 52.8 tons.

Actual horse power: 657 .

Speed: 20 knots.

Rudders: 2.

Armament: one $47 \mathrm{~m} . \mathrm{m}$. light quick-firing gun, 2 torpedo tubes.

Boats No. 22 and No. 23 were made by the Schichan Company of Germany and purchased also as model boats. They were designed to have a displacement of 82 tons, I,200 horse power and a speed of 24 knots, but in their steam trial a result of only 926 horse power and $\mathrm{I} 8.84$ knots in speed was obtained.

All of the above torpedo boats are third class.

In February, 27 Meiji (I894), construction work on boat No. I9 was completed, and in March that on boat No. II. These two boats were both of the same type as boat No. Io and third class, and built at the Onohama Branch Yard of the Shipbuilding Division of the Kure Naval Station.

\section{Supplement}

In closing this section we present some chronological tables of the building of the warships, torpedo-boat destroyers, and torpedo boats built at domestic yards from the Restoration to the Sino-Japanese War, as herein stated. 
Chronological Table Showing Building of IVarships and TorpedoBont Destroyers

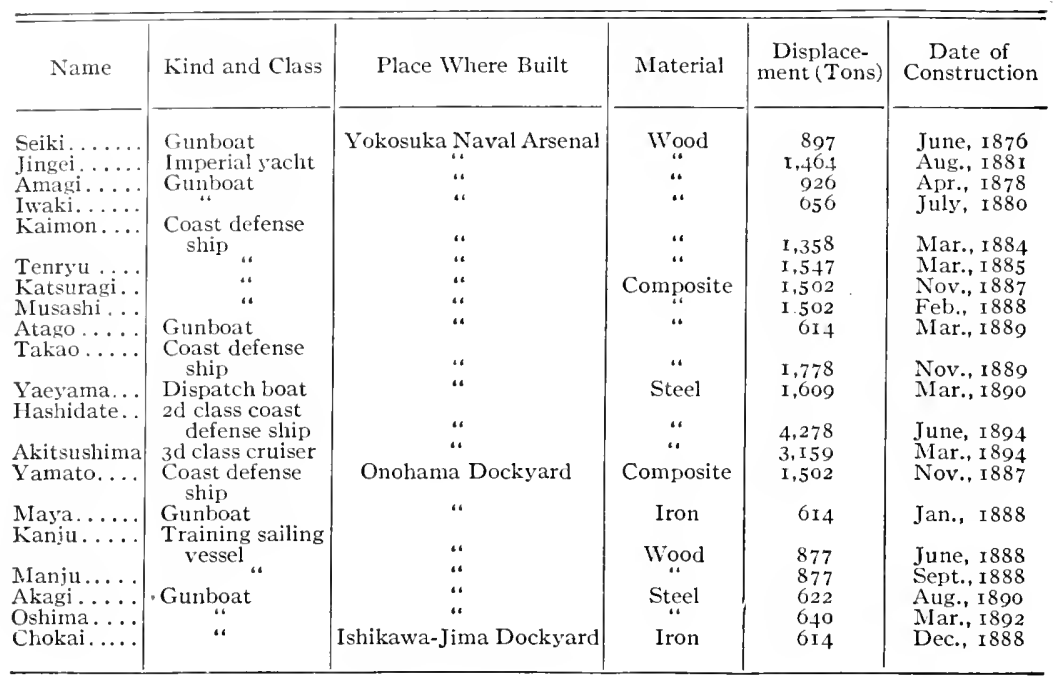

Chronological Table of the Making of Torpedo Boats

(From the Restoration to the Sino-Japanese IVar)

\begin{tabular}{|c|c|c|c|c|c|}
\hline Name & Kind and Class & Place Where Built & Material & $\begin{array}{l}\text { Displacement } \\
\text { (Tons) }\end{array}$ & $\begin{array}{l}\text { Date of } \\
\text { Construction }\end{array}$ \\
\hline 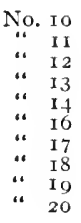 & $\begin{array}{c}\text { Torpedo boat } \\
\text { “. } \\
\text { “. } \\
\text { “. } \\
\text { “. }\end{array}$ & 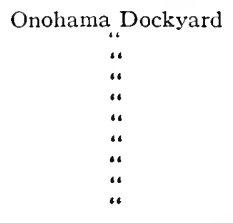 & 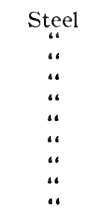 & 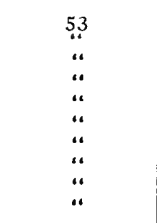 & $\begin{array}{c}\text { Apr., } 1892 \\
\text { Mar., } 1894 \\
\text { Oct.,., } 1893 \\
\text { “. } \\
\text { ". } \\
\text { Nov... } 1893 \\
\text { Feb., } 1894 \\
\text { Oct., } 1893\end{array}$ \\
\hline
\end{tabular}




\section{CHAPTER III}

\section{FROM THE SINO-JAPANESE WAR TO THE RUSSO- JAPANESE WAR}

The Sino-Japanese War of the years 27 and 28 Meiji (1894-1895) was in itself a new standard and plan for the expansion of the army and the nary of the Japanese Empire. As the war was fought by two powers on an equal footing in the Far East-one, the Island Empire, with all the civilized methods which it had indefatigably for the thirty years since its opening taken in from the IVest, in addition to the nation's own characteristic military arts and tactics; the other, that vast old country of the Orient, who, by her early friendship with Europe, was also well fitted with modern arms and warships, and was casting a look of supremacy over other nations of Eastern Asia-it was watched by the nations concerned with special interest as an opportunity for them to determine the relative strength. It also attracted the attention of European specialists who were equally interested in the event as proving to them the actual powers of arms and war vessels made by the application of the latest fast developing science and arts.

The war resulted in victory for Japan; and this, having put her in a new and heavily responsible position, made her feel the necessity of speedily increasing her military preparations. At the same time, the war gave her much useful experience in the remodeling and improvement of military weapons and war vessels. On account of this necessity and with those experiences, the Island Empire, after the war, began to increase the number of divisions in its army and to organize some new special companies of troops; and in the navy, to enlarge naval stations and establish new ones, increase the number of war vessels, build large warships, and so forth. So the army and the navy worked on industriously, competing with each other, to complete their task, and in the ten years which followed the 
war until the next war (with Russia) commenced, they carried out the expansion of their forces, enlarging them in a leap to more than double their old size. The development of the military industry in this interval of time was particularly remarkable, and the achievements made were great not only in quantity, but also in the fact that many new plans in the arts of manufacture, that had never been seen even in Europe or America, were designed and worked out during this time. Indeed, those select weapons and instruments of war which were used later on in the Russo-Japanese War were mostly the product of this period.

\section{INDUSTRIES OF THE ARMY}

The factories that were newly established for the army in the period under consideration were the Military Clothing Department, the Provision Department and the Department of Railway Materials. The Clothing and Provision Departments were established with the object of economizing military expenses and facilitating the selection of the supplies manufactured in the military factories. This was done as a consequence of the general enlargement of military preparations made after the war which increased the army's demand for clothing and provisions in both peace and war times. The Department of Railway Materials was established to repair railway materials and for the manufacture of various supplies. As for the factories already in existence, both the Tokyo and Osaka Arsenals were enlarged and their producing capacities were doubled. The greatest. work done in this period was the improvement of arms, principally the infantry and cavalry rifles of the 3oth year pattern, the quick-firing field and mountain artillery guns of the 3 Ist year pattern, all kinds of garrison artillery guns and the ammunition for all these guns and rifles.

Before going further in showing the development of the manufacturing industry of arms and ammunition, we will review in a general manner the changes undergone by the factories for those manufactures during this period. 


\section{Weapon Factories}

(I) The Tokyo Arsenal.-At the commencement of the Sino-Japanese War in June, 27 Meiji (I 894), all the factories of the Tokyo Arsenal enlarged their workshops at the same time, increased their machinery, built temporary factory rooms and made various other preparations to meet the requirements of the moment.

In October of the same year, the manufacture of mercuric fulminate, which had been carried on in the ammunition factory up to that time, was transferred to the Itabashi powder mill.

In April, 28 Meiji (I895), the Meguro powder mill was enlarged for the manufacture of brown powder.

In December of the same year, the sulphuric acid factory, which belonged to the Bureau of Imperial Estates of the Department of the Imperial Household, was put under the administration of the Tokyo Arsenal, as an annex to the Itabashi powder mill, and was named the Oji Chemical Works.

In March, 29 Meiji (I 896), the factory for gun accessories and three other factories, viz., the woodwork, the forging and the casting, which had been leased to private parties since 23 Meiji (I890), were taken back, and work was immediately started in them.

In October of the same year, the extension of the third chemical works of the Itabashi powder mill was completed and chemical work by new machinery was started.

In January, 30 Meiji (I897), water supply pipes were laid, and a telephone was put up in the main factories of the arsenal in Koishikawa. This greatly facilitated the work of those factories.

In March of the same year, an ether and alcohol factory was set up in the Itabashi powder mill.

In April of the same year, the mercuric fulminate factory of the ammunition factory was closed and its work was united with that of the high explosive mill.

In April, 33 Meiji (I900), the regulations of the Arms In- 
spection Bureau were enacted. These placed the arsenals under the control of an inspector general, and thereafter all articles issuing from the arsenal factories were to be inspected by a certain number of inspectors who were to be stationed at the arsenals and act under the command of the inspector general.

In 34 Meiji (1902) articles were drawn for the Gijo-Kwai (a relief society) to promote the mutual relief of the workmen.

In April, 35 Meiji (1903), a part of the finance law for military works was revised, by which those buildings and other structures and ships hitherto in use in the arsenals as government property, and those to be added to them in the future, were put into the list of the fixed capital of the arsenals, and the expenses for their maintenance, repairing and replacing, were to be charged up to the work expense account.

In July of the same year, a wire-rope transmitter and elevators were set up in the Meguro powder mill, and proved to be a great saving of labor in the transmission of raw materials and manufactured goods.

In August of the same year, the number of workmen to be employed at ordinary times in the arsenals was fixed at 5,00o, of whom 3,250 were for the Tokyo Arsenal.

(II) The Osaka Arsenal.-With the beginning of the SinoJapanese IVar in June, 27 Meiji (I894), some enlargement of working rooms, and increases in machinery, number of workmen, etc., were effected in the factories of this arsenal, as was the case with those of Tokyo.

In November of the same year, it was decided that a powder mill should be set up in the village of Uji in Uji District, Kyoto Prefecture, and the work of construction was started. This was afterward named the Uji powder mill.

In June, 29 Meiji (I896), the construction of the enlargement of the arsenal was commenced, and the work of the extension and rebuilding of the factories for guns, gun carriages, shot and ignition tools was started. This enlargement was originally attempted at the time when, during the war of 27 and 28 Meiji (1894 and I895), owing to the insufficiency of 
the producing capacity, it was found necessary to enlarge the arsenal. Then a plan for it was made in November 27 Meiji (I894), and was about to be carried out when, however, the war ended and the scheme was abandoned. After peace was established, an enlargement became necessary to conform with the plan of general increase of military preparations, and the approval of the Diet having been obtained on the original plan for an expense of above I,540,000 yen for the two fiscal years of 29 and 30 Meiji (I896 and I897), the work was finally brought to completion.

In August, 29 Meiji (I896), the construction of the Uji powder mill was completed; also the fixing of the machinery on the premises.

In March, 30 Meiji (I897), the Moji Arms Repairing Works were attached to the Osaka Arsenal.

In February, 3I Meiji (I 898), a lunch box factory was set up in the ordnance factory for the first time.

In May of the same year, for the first time an electric transverse crane was built in the ordnance factory.

In July of the same year, a telephone service was put up in the arsenal connecting all the offices and factories.

In August of the same year, the factory building for the 27 c.m. cannon were completed.

In September of the same year, a gas furnace for tempering edged tools was built. In the same month the hydropressing house for the case factory was set up.

In April, 33 Meiji (I900), the implement factory was established.

In August, 34 Meiji (I90r), electricity was introduced as the motive power for the casting work of the shell factory. From this initiative other factories, one after another, used electric power, and steam, which was up to that time the only power used, now came gradually into disuse.

In December of the same year, the arsenal was furnished with a $\mathrm{I}, 200$ ton hydraulic forging machine.

In June, 36 Meiji (1902), a shell-making machine for the quick-firing field and mountain artillery guns was installed, 
and the work hitherto done by the screw press was discontinued.

In December of the same year, women were employed for the first time in this arsenal in the work of casting lead bullets.

\section{Arms}

Early in the summer of 27 Meiji (I894) the relations between Japan and China were becoming more and more threatening, and work in the two arsenals of Tokyo and Osaka became heavier. Great efforts were made to supply and increase their machinery, work hands, materials, etc. In June diplomatic relations were broken off and war was declared. Thereupon, great quantities of arms and ammunition being urgently needed, the work of the arsenals became still more pressing; so the force of workmen in the Tokyo Arsenal, of whom there was at that time not more than 2,800, was gradually increased until, on August 1 , it amounted to more than 3,300, and on December I to about 5, Ioo.

In July of the same year, a 9 c.m. mortar was cast in the Osaka Arsenal.

In December of the same year, two workmen were sent from the Tokyo Arsenal to the Galileo manufactory in Italy, for a period of three years, to make a practical study of range finders and apparatus for communication. This was the first time that ordinary workmen were dispatched abroad.

In December, 28 Meiji (I895), work by steam hammer was started in the small arms factory of the Tokyo Arsenal.

In July, 29 Meiji (I896), Artillery Colonel Nariaki Arisaka, Chief Superintendent of the Tokyo Arsenal, started the trial manufacture of the rifle of the 3 oth year pattern.

In August of the same year, a I2 c.m. quick-firing gun was cast in the Osaka Arsenal.

The Maxim machine gun had up to this time been used by all machine gun companies of gunners. However, the Hotchkiss machine gun was now invented and this latter gun was purchased, and tested by the Ordnance Committee. These tests proving satisfactory, it was remodeled, its caliber being made the same $(6.5 \mathrm{~m} . \mathrm{m}$.) as the 3 oth year infantry rifle. 
In April, 3o Meiji (r897), the trial manufacture of the 3oth year infantry rifle was finished.

In November of the same year, a canteen making machine was installed in the Tokyo Arsenal, and for the first time a canteen was manufactured.

In February, 3I Meiji (I899), the official pattern of the 3oth year rifle was fixed.

In the same month a lunch box was manufactured for the first time at the ordnance factory of the Osaka Arsenal.

In August of the same year, the manufacture of the 3 Ist year quick-firing field and mountain artillery guns was begun. Previous to the adoption of these quick-firing guns as regulation arms, there were three different kinds of regulation quickfiring guns which were the products of studies carried on since 25 Meiji (I892) and called respectively patterns No. I, No. 2 and No. 3. Pattern No. I was made from a design by Colonel Arisaka; No. 2 was made by the Osaka Arsenal, and No. 3 was designed by the Ordnance Committee. Again, pattern No. I was of a recoil brake mechanism, had a recuperator spring and no spade on the trial; No. 2 had an elastic spade on the trial; No. 3 was of the hydraulic buffer system, had a recuperator spring and had a spade fixed on the trial. The barrels of the No. I and No. 3 guns were steel mantled, and that of No. 2 was made of steel bronze. All of their gun carriages were made of steel. The 3 Ist year quick-firing gun was a further improved form of the above pattern No. I, and was this year decided upon by the Ordnance Committee as the regulation gun and called the quick-firing field artillery gun of the 3 Ist year pattern. It was also decided that the same pattern be followed in the manufacture of mountain artillery guns.

In October of the same year, the first manufacture of the 3oth year infantry rifle and bayonet was made in the small arms factory of the Tokyo Arsenal.

In January, 32 Meiji (r899), the manufacture of a $27 \mathrm{c.m}$. cannon of 30 caliber was started at the Osaka Arsenal.

In March of the same year, the manufacture of the 3 ist 
year quick-firing field and mountain artillery gun, which had been started in August of the previous year, was finished.

In August of the same year, a cavalry rifle of the zoth year pattern was for the first time manufactured at the small arms factory of the Tokyo Arsenal.

In April, 33 Meiji (1900), the manufacture of edge tools was started at the implements factory newly set up in the Osaka Arsenal.

In June of the same year, the manufacture of crucible steel at the Osaka Arsenal, which had been discontinued for some time, was resumed, and steel ingot and castings were produced.

In December, 33 Meiji ( I 900), the manufacture of a $27 \mathrm{c.m}$. cannon of 30 caliber at the Osaka Arsenal was finished.

In the year of 34 Meiji (190I), at the Osaka Arsenal, nickel steel ingot was cast for the first time by the acid furnace. In this arsenal this was the first instance when any special steel was manufactured by a Martin furnace.

In the $35^{\text {th }}$ year of Meiji (1902), the manufacture of the 3 Ist year quick-firing field and mountain artillery guns, the work of which had been in progress since the beginning, advanced so far that all the field forces of the army were now completely equipped with the new guns. But, although it was evident from the result of a comparative test that the 3 Ist year quick-firing field artillery gun excelled all the other guns made in Japan, the similar study then being made in Europe was a further step in advance, and many new quick-firing guns better than any of those in this country were being produced and distributed among all the troops on that continent. In view of this fact, it was thought necessary to make a further improvement in the quick-firing guns of Japan, and the study was again taken up. Soon after this, however, the war between Japan and Russia began, and it had to be fought with the 3 Ist year quick-firing guns.

\section{Ammunition and Ignition Tools}

In June, 27 Meiji (1894), the manufacture of No. I and 2 plain powder and the smokeless powder for the rifle was begun at the Itabashi powder mill. 
In November of the same year, a suitable arrangement was made in the ammunition factory of the Tokyo Arsenal to turn out the cartridges of the Murata magazine rifle at the rate of 400,000 every twenty-four hours; also, machines for stuffing the powder and filling the bullet were devised, and the old handwork gave way to machine work.

In the same month, gun powder and shell for the $15 \mathrm{c.m}$. steel-bronze cannon, those for the $\mathrm{I} 2 \mathrm{c} . \mathrm{m}$. cannon, and a fuse for the latter cannon were manufactured for the first time at the Osaka Arsenal.

Owing to the fact that the Sino-Japanese War started in this year, the demand for ammunition and ignition tools increased so rapidly that the force of workmen was at once reinforced, new factories and machinery were added, and the work was pushed by day and night.

In March, 28 Meiji (I895), the manufacture of smokeless powder for field and mountain artillery guns was started at the Itabashi powder mill, and in May the manufacture of No. 2 square powder was also started at the same mill.

In December of the same year, a study of the cartridge for the 3 oth year rifle was commenced at the ammunition factory of the Tokyo Arsenal.

In June, 29 Meiji (I896), the ammunition and ignition tool factories of the Osaka Arsenal were enlarged, and their producing capacity was greatly increased, enabling them to produce such things as the cartridge case for guns of medium caliber.

In October of the same year, the blank cartridge of the 26 th year revolver, the study of which had been continued since 25 Meiji (I 892), was completed at the ammunition factory of the Tokyo Arsenal.

In November of the same year, the study of yellow burster manufacturing was taken up at the Tokyo Arsenal.

In March, 30 Meiji (I 897), the study of the 3oth year rifle cartridge was completed.

In April of the same year, the manufacture of ether and alcohol was started at the Itabashi powder mill.

In April, 3I Meiji (I898), the manufacture of yellow powder was started at the Oji Chemical Works. 
In May of the same year, the temporary compound fuse for the 3 Ist year quick-firing mountain gun was manufactured at the Osaka Arsenal; this was the forerunner of the I8-second compound fuse, the manufacture of which was perfected later on.

In June of the same year, the blank cartridge for the 3 oth year rifle was manufactured at the ammunition factory of the Tokyo Arsenal.

In December of the same year, for the first time shrapnel shell for 12 c.m. quick-firing cannons and common shell for the 3 Ist year quick-firing mountain gun were manufactured at the Osaka Arsenal. In the same month a cartridge case for I2 c.m. cannons was also manufactured there for the first time.

In February, 32 Meiji (I 899), a cartridge for the 3oth year rifle was manufactured for the first time at the ammunition factory of the Tokyo Arsenal.

In the same month, by melting the yellow powder, the manufacturing of various kinds of bursters for common shells was started at the Tokyo Arsenal.

In the same month shrapnel for the 3 Ist year quick-firing field and mountain artillery guns, in May a base fuse for the same guns, in June a cartridge detonator for the same, in August a cartridge case for 9 c.m. cannons, in September high explosive shell for the Krupp io c.m. cannons, the Krupp I2 and 15 c.m. howitzer, and in December a cartridge case for I 2 c.m. howitzer were manufactured at the Osaka Arsenal, all for the first time. In February, 33 Meiji (I900), shrapnel shell for 27 c.m. cannons was made for the first time at the Osaka Arsenal.

In April of the same year, the manufacture of the Nos. 2, 3 and 4 smokeless powder of belt form was started at the Itabashi powder mill.

In October of the same year, for the first time at the Osaka Arsenal, a steel shell for the quick-firing field and mountain guns was made. By the same method various other steel shells were manufactured after that time. In the same month a training shell for the 3 Ist year quick-firing mountain gun 
was manufactured for the first time; also, a 32 -second compound fuse.

In May, 34 Meiji (I90I), the Osaka Arsenal cast by its acid furnace chrome-steel of ferro-chrome compound, of which it made some $24 \mathrm{c} . \mathrm{m}$. cannon breach shells on trial. This was the beginning of the manufacture of nickel-chrome steel. In July, shrapnel for the quick-firing field and mountain guns was made for the first time, with the use of steel made in the arsenal. In August, breach shells for the 12 and $15 \mathrm{~cm}$. guns were made for the first time.

In July, 35 Meiji (I 902), tests of nitro-glycerine and dynamite were made at the Itabashi powder mill.

In the same month, at the Osaka Arsenal the casting of the cartridge-case material was started, using electro-refined copper.

In November of the same year, shrapnel for the 3Ist year quick-firing field gun was manufactured for the first time at the gun accessories factory of the Tokyo Arsenal.

The Osaka Arsenal, in the same year, made a 24 -second compound fuse. This fuse was made by remodeling the 32second fuse by changing the fire-channel powder to one nearly of the same kind; and it could be used for cannon above 9 c.m. Next to this fuse, an I 8 -second compound fuse was also made at the arsenal for the first time. It was a fact that the official adoption of the 3 Ist year quick-firing guns had brought about a great change in the make of the fuse. Made like the compound fuse for $7 \mathrm{c} . \mathrm{m}$. cannons, the fuse ignited well enough in its fire channel if used with a mountain gun, but not with a field gun. Therefore, in making the fuse for the 3ist year quick-firing guns, the fire channel was formed of a plate with a ring of gun powder, for which no powder compounded with niter and sulphur was used as was usual with the fuses made up to that time, but a granular black powder was used and stuffed directly into the plate. This alteration not only removed the causes of the nonignition of the fire channel, but greatly promoted the accuracy of its combustion, and the fuse so improved was the 18 -second compound fuse. 


\section{Industries of the Navy}

The responsibility of Japan to maintain the peace of the Far East was as much heavier as her prestige was raised after the Sino-Japanese VTar. The perfection of military preparations due to her new position was therefore necessary, and to attain this end it was decided that a second enlargement be made of the navy. The general plan was to increase in a comparatively short time the force of naval vessels of Japan to a number four times as large as it was at the time. Furthermore, it was decided to open a naval port at Maizuru and establish a naval station there, also to establish a secondary naval station at Ominato. The time in which the work of enlargement was to be completed was fixed at ten years from the 29th year of Meiji (I896), and the total expense was estimated at 250,900,ooo yen. But the capacity of the naval and private dockyards of the country not being sufficient to do the work even with their full force, a greater part of the work had to be apportioned to four foreign countries,--England, the United States of America, France and Germany,-to ensure its completion within the prescribed time. The war vessels to be built upon the present plan of enlargement were 4 first-class battleships, 6 first-class cruisers, 3 second-class cruisers, 3 third-class cruisers, 3 second-class gunboats, I dispatch boat and 23 torpeclo-boat destroyers, 43 in all; besides, I4 first-class torpedo boats, 37 second-class torpedo boats and io third-class torpedo boats, 63 in all. This was no doubt a very rapid increase in the old Japanese naval force; and, in addition, the highly finished work accomplished from the experiences obtained from the Sino-Japanese War, coupled with the latest advanced arts and science, completely changed the condition of the Japanese Navy. The principal improvements made in the above war vessels as based on the instruction gained from the late war were reconstruction of the protective deck, the equipment of battleships with big guns, increase of speed, structural reform of the torpedo, provision against fire on board, etc. We will state in chronological order how these improvements were made in each of the vessels built. 
The factories and workshops established in the present period are as follows:

The Maizuru Naval Dockyard.-Business was commenced in October of 34 Meiji (I90I) at the same time as the opening of the Maizuru Naval Station, the construction of which had been going on since May, 29 Meiji (I896). The name of the dockyard was altered to the Maizuru Naval Arsenal in November, 36 Meiji (1903). The object of the dockyard was mainly to repair war vessels, and the accommodations for building new ships were only secondary, the same as those of the Sasebo Dockyard.

The Naval Factory for Shimrose Gun Powder.-Established in Tokyo in April, 32 Meiji (I 899).

The Workshops of the Takeshiki Naval Station (a secondary station).-Established in May, 33 Meiji (1900).

The Workshops of the Bako Naval Station (a secondary station).-Established at the same time as the station, July, 34 Meiji (I90I).

The Naval Workshops for Repairs.-Established in Ominato as an annex to the Torpedo Department begun there in July, 35 Meiji (I902).

Besides the above, some new factories and workshops were established, or the old ones enlarged, in the naval stations of Yokosuka, Kure and Sasebo, in consequence of their reorganization.

In September, 30 Meiji (I897), "Shipbuilding Division," the name by which the dockyards of the above mentioned naval stations had been called, was altered to "Dockyard," and further in November of 36 Meiji (1903) to "Naval Arsenal," at the same time the dockyards being given the power to control all the other factories or workshops in the stations. The Naval Arsenal in Tokyo was reorganized twice-May, 30 Meiji (I897), and November, 36 Meiji (1903).

\section{Warships and Torpedo-boat Destroyers}

(I) Warships.-In December, 29 Meiji (I896), the warship Suma was built at the Yokosuka Naval Arsenal. She 
was laid down in August, 25 Meiji (I 892). She is a sister ship to the $A k a s h i$, and is a third-class cruiser, being in general like the Akitsushima in her plan and construction and having double bottoms, a protective deck, and twin screw, surfacecondensing, vertical, triple-expansion engines. Her displacement is 2,657 tons, horse power, 850 , and speed, 20 knots. She has mounted on her two I 5 c.m. main guns, six I 2 c.m. side guns, ten $47 \mathrm{~m} . \mathrm{m}$. heavy guns and two light guns as auxiliary guns; and has two I4-inch torpedo tubes, and 3 searchlights.

In March, 32 Meiji (I899), the warship Akashi was completed at the Yokosuka Naval Arsenal. She was laid down in August, 27 Meiji ( I 894). She is a sister ship to the Suma and is of about the same construction as the latter, but as she was built two years later than the other, she is somewhat better. Her displacement is 2,920 tons, horse power, 7,396, and speed, I 9.52 knots. She has two 6-inch quick-firing guns as main guns, seven 4 -inch guns and six quick-firing guns as side guns, and twelve 3 -pound quick-firing guns and two $2 \frac{1}{2}$-pound quick-firing guns as auxiliary guns, and has 3 searchlights.

In March, 32 Meiji (I 899), the coast defense ship Miyako was completed. She was laid down in May, 27 Meiji (1 894), at the Kure Naval Arsenal. Engines, twin screw, surface condensing, and triple expansion. Displacement, I,772 tons; horse power, 6,000; speed, 20 knots. Guns, etc., two I 2 c.m. main guns; six $47 \mathrm{~m} . \mathrm{m}$. heavy guns and four $47 \mathrm{~m} . \mathrm{m}$. light guns (auxiliary); 2 torpedo tubes; 2 searchlights.

In May, 33 Meiji (I900), the warship Chihaya was completed at the Yokosuka Naval Arsenal. She was laid down for a dispatch boat in May, 3I Meiji ( I898). Displacement, I, 238 tons; horse power, 6,000; speed, 2 I knots. Her protective deck is over only one part of her stern and is made to protect merely her steering engine and rudder head. This ship is called by another name of "torpedo gunboat," being peculiar in her plurality of torpedo tubes, of which there are five in all, one in the bow and the rest in the bulwarks (two in each), set in couples on the upper deck.

In August, 36 Meiji (I903), the second-class gunboat Uii 
was completed. The ship was built at the Kure Naval Arsenal, having been laid down in September, 35 Meiji (I902). Her displacement is 610 tons, horse power, Ioo, speed, I3 knots, and engines, twin screw and surface condenser. She was designed for a light draught river gunboat, being of about seven feet draught. Though she has about the same displacement as the gunboat $A$ kagi, her draught is less by two feet, eight inches, and therefore it may be said that she is a comparatively light draught boat. She has four I2-pound quick-firing guns as main guns, 3 Maxim guns as side guns, and I searchlight, but no torpedo tube.

In January, 37 Meiji (I904), the third-class cruiser Niitaka was completed at the Yokosuka Naval Arsenal. Her displacement is 3,366 tons, horse power, 9,400, and speed, 20 knots, and she has six 6-inch quick-firing guns as main guns, ten I 2-pound quick-firing guns as side guns, four $47 \mathrm{~m} . \mathrm{m}$. guns as auxiliary guns, and 3 searchlights. In spite of the customary equipment of a warship of this kind with torpedo tubes, she and her sister ship Tsushima are not equipped with any, for the reason that an unprotected torpedo tube is apt to expose its own ship to danger instead of injuring the enemy. It may be added that the third-class cruiser Tsushima was laid down in October, 34 Meiji (I90I), at the Kure Naval Arsenal, also the Otowa, another third-class cruiser, in January, 36 Meiji (1903), at the Yokosuka Naval Arsenal, but neither was completed before the Russo-Japanese War.

(II) Torpedo-boat Destroyers.-The building of torpedoboat destroyers in the Japanese Navy commenced in the 3oth year of Meiji (I897), when certain destroyers were built by England, to whom the government had entrusted the memorable work. Afterward the navy tried and finally learned to build its destroyers at its own dockyards by modeling them after the English ships already possessed by it and adding some improvements from the study and experiments made of their predecessors. The following is a history of the construction of torpedo-boat destroyers in Japan after it was begun at the domestic yards. 
In March, 35 Meiji (I902), four torpedo-boat destroyers, the Harusame, Murasame, Hayatori and Asagiri, were laid down. This was the first time torpedo-boat destroyers were built at home.

In June, 36 Meiji (1903), the torpedo-boat destroyer Harusame was completed at the Yokosuka Naval Arsenal. Displacement, 375 tons; horse power, 600 ; speed, 29 knots. Guns, etc., two 12 -pound quick-firing guns; four 57 m.m. quick-firing guns; 2 torpedo tubes; $x$ searchlight.

In July of the same year the Murasame was completed, in August, the Hayatori, in September, the Asagiri. They were all built at the Yokosuka Naval Arsenal; their displacement, horse power, speed, guns, etc., are all the same as those of the Harusame.

These four ships were designed and built to be sister ships. Their engines were made exclusively after the Yarrow type, being arranged and constructed in strict conformity to the type of the same company. They are of a twin screw, surface condensing, vertical, and triple expansion system. The cylinders are of cast iron and have no lining. The slide valves are cylindrical and made of manganese bronze. Each engine is furnished with a condenser. According to the Yarrow system, the water circulation of the condenser was arranged so that water flows into the condenser pipe by itself as the ship navigates at full speed. But experience having proved that this was not desirable, a different system was adopted in the case of the ships of the Harusame class, in which a circulating pump is placed in the ship especially for the purpose of drawing sea water through a Kingston valve at the lowest bottom of the ship. Materials for the different parts of the engine are of the best and choicest kind obtainable. All the connecting rods, crosshead guides, etc., in the slide valve connection are case hardened, and for other parts manganese bronze was mostly used. The high speed trials of the four destroyers mentioned were not satisfactory, owing to the total lack of skill on the part of the engineers and firemen employed in the handling of such high speed vessels. Yet the average results 
showed a working pressure of 190 against the maximum of 257 , a revolution of 379 against 400 , a horse power of 5,600 against 6,000 , with a speed of 29 knots in all cases.

All the destroyers-were fitted with four water tube boilers of the Kansei Honbu type (the type adopted by the Ship Administration Office of the Imperial Navy). This kind of boiler was first placed in the warship Otowa with good results, and that led to its use in the destroyers.

On account of the unusual pains taken by shipbuilders in the construction of torpedo-boat destroyers, the work on the above four ships, the Harusame and others, progressed without the slightest interruption and was even crowned with a successful official trial, all of which facts, it may be said, added much to the fame already won by the progress of the shipbuilding industry in Japan.

\section{Torpedo Boats}

In January, 28 Meiji (I 895), torpedo boat No. 24 was built at the Kure Naval Arsenal. Her displacement is 78 tons, horse power, I, I5O, and speed, 21 knots. This boat is of the same type as boat No. 2 I built by the Normand Company.

In February of the same year, torpedo boat No. 25 was built at the branch of the Kure Naval Arsenal. This boat was built after the designs of No. 22 and No. 23, the Schichau 80ton boats purchased from the Schichau Company of Germany and put together at the same branch yard. She was launched in November, 27 Meiji (1894). Displacement, 82 tons; actual horse power, I,200; speed, 24 knots. Guns, etc., two 47 m.m. quick-firing guns; 3 torpedo tubes. Loading capacity of coal, $87 \frac{1}{2}$ tons; 2 rudders, fore and aft; the fore rudder measuring above 6 square feet, and the aft rudder i 4 square feet.

The first-class torpedo boats Hayabusa, Kasasagi, Manazuru and Chidori, which had been bought from the Normand Company of France, were framed during the $32 \mathrm{~d}$ year (I899) and 33d year (1900) of Meiji and completed sometime between April of the 33d year (I900) and April of the 34th year (I90I), Meiji. The work of building these torpedo boats from pur- 
chased parts gave a great deal of valuable experience for the future building of many ships of this kind.

In November, 33 Meiji (I900), torpedo boat No. 50 was completed at the Yokosuka Naval Arsenal. It was laid down in April, 32 Meiji ( 1899 ). Displacement, 52 tons; horse power, 657 ; speed, 20 knots. She is a slightly improved form of the 53-ton boat No. 15 of the Normand type.

In the same month torpedo boat No. 5I was completed at the Yokosuka Naval Arsenal. The boat was built the same as No. 50 in all respects.

In February, 34 Meiji ( I 90I), torpedo boat No. 52 was built at the Yokosuka Naval Arsenal. She was laid down in May, 32 Meiji (I 899), and was built the same as the two preceding boats in all respects.

In April, 34 Meiji ( I 90I), torpedo boat No. 53 was completed at the Kure Naval Arsenal. It was laid down in April, 33 Meiji (1900). Displacement, 52 tons; horse power, 657; speed, 20 knots.

In the same year torpedo boat No. 54 was built at the Kure Naval Arsenal. She was built the same in all particulars as No. 53 .

In May, 34 Meiji (I90I), torpedo boat No. 55 was built at the Kure Naval Arsenal. This boat was also built the same as the two previous ones in all respects.

In August, 35 Meiji (I902), torpedo boat No. 56 was completed at the Yokosuka Naval Arsenal. It was laid down in April, 35 Meiji (1902). Displacement, 52 tons; horse power, 657 ; speed, 20 knots.

In November, 34 Meiji (I9OI), torpedo boat No. 57 was completed at the Kure Naval Arsenal. It was laid down in March, 34 Meiji (I90I). Displacement, 53 tons; horse power, 660 ; speed, 20 knots.

In January, 35 Meiji (I902), torpedo boat No. 58 was completed at the Kure Naval Arsenal. It was laid down in April, 34 Meiji (I90I). She is the same as the last mentioned boat in displacement, horse power, speed, etc.

In April, 35 Meiji (I902), torpedo boat No. 59 was completed at the Kure Naval Arsenal. It was laid down in 
August, 34 Meiji (I9OI). She is the same as No. 58 in construction and otherwise.

Of the above ten boats (beginning with No. 50), those built at the dockyard of the Yokosuka Naval Arsenal had metal aluminum used for their furniture, fixtures, utensils, etc. This fact, together with the careful saving of weight in other materials used in the side manufacture, enabled the builders to bring down the tonnage of the boats to 52 tons. Another new trial very successfully made by this dockyard in connection with these boats is the use of the abacus system of launching for torpedo boats. This method of launching was in those years in practice at the dockyard for all the auxiliaries built there, and now it was adopted for every torpedo boat built at the yard.

The displacement of the other boats built at the Kure Naval Arsenal is 53.4 tons.

In June, 36 Meiji (1903), torpedo boat No. 67 was completed at the Yokosuka Naval Arsenal. She was laid down in May, 35 Meiji (1902). Displacement, 94 tons; horse power, I,200; speed, 23.5 knots.

In the same month torpedo boat No. 68 was completed at the same arsenal. Her displacement, horse power, speed, etc., are all the same as No. 67. The average cost of these two boats is II 4,45 I yen.

In September, 36 Meiji (1903), torpedo boat No. 72 was completed at the Yokosuka Naval Arsenal. She was laid down in February of the same year. Displacement, 94 tons; horse power, $\mathrm{I}, 200$; speed, 23.5 knots.

In the same month, torpedo boat No. 73 was completed at the Yokosuka Naval Arsenal. The time she was laid down, her displacement, horse power, speed, etc., are all the same as No. 72. These two boats cost on the average 89,632 yen.

In September, 36 Meiji (I903), torpedo boat No. 69 was built at the Sasebo Naval Arsenal. She was laid down in May, 35 Meiji (I902). Displacement, 94 tons; horse power, I,200; speed, 23.5 knots. She is the first torpedo boat built at the Sasebo Dockyard.

In November, 36 Meiji (1903), torpedo boat No. 70 was 
completed at the Sasebo Naval Arsenal. It was laid down in May, 35 Meiji (I902). Dịsplacement, horse power, speed, etc., the same as the last-mentioned boat.

In December, 36 Meiji (I903), torpedo boat No. 7I was built at the Sasebo Naval Arsenal. It was laid down in August, 35 Meiji (I902). She is the same as the last two boats in displacement, horse power, speed, etc.

In June, 37 Meiji (I904), torpedo boat No. 74 was completed. The boat was built at the Kawasaki Dockyard, having been laid down in June, 36 Meiji (1903). Her displacement is 89 tons, horse power, I,200, and speed, 23.5 knots.

In the same month torpedo boat No. 75 was completed at the same dockyard. She was laid down in the same month as the last-mentioned boat. Her displacement, horse power, speed, etc., are also the same as No. 74. The nine boats which have just been mentioned, beginning with No. 67 , are an improved form of boat No. 25 of the Schichau 8o-ton type. Compared with No. 25, they are somewhat larger in size, less in draught, but increased by $13 \frac{1}{2}$ tons or more in displacement, the same in horse power and less by $\frac{1}{2}$ knot in speed. Each has two $57 \mathrm{~m} . \mathrm{m}$. guns and three torpedo tubes.

There is a disparity of 24,8 I 9 yen between the cost of boats Nos. 67 and 68 and that of Nos. 72 and 73, all of which were built at Yokosuka. The reason is that, in the case of the building of the latter boats, economizing was possible in the working expense, as there was a certain quantity left over of the materials appropriated for the building of the former, that could be used for the latter. The completeness of working accommodations by the time of the construction of the latter boats is another powerful reason for the difference.

In July, 36 Meiji (1903), the first-class torpedo boat Kari was built at the Kure Naval Arsenal. She was laid down in April of 35 Meiji (I902). Her displacement, horse power and speed are $150,4,200$ and 29, respectively.

In August, 36 Meiji (I903), the first-class torpedo boat Aotaka was completed. She was built at the Kure Naval Arsenal, having been laid down in April, 35 Meiji (I902). 
Displacement, horse power, speed, etc., are the same as those of the Kari.

In October, 36 Meiji (1903), the first-class torpedo boat Hato was completed. She was built at the Kure Naval Arsenal, having been laid down in May, 35 Meiji (r902). Her displacement, horse power, speed, etc., are all the same as those of the last-mentioned boat.

In November, 36 Meiji (1903), the first-class torpedo boat Tsubame was completed at the Kure Naval Arsenal. It was laid down in June, 35 Meiji (I902). Her construction is the same as that of the Kari in all details.

In January, 37 Meiji (I904), the first-class torpedo boat Hibari was completed at the Kure Naval Arsenal. It was laid down in July, 35 Meiji (I902). Displacement, horse power, speed, etc., the same as those of the Kari.

In January, 37 Meiji (I904), the first-class torpedo boat Kiji was completed at the Kure Naval Arsenal. She was laid down in September, 35 Meiji (I902). Construction, the same as the Kari.

The above are all first-class torpedo boats of the Normand type. They invariably passed the official trial with good results. Their speed was fully 29 knots. They were the highest speed torpedo boats ever built, and the success which attended their building is enough to show the great advancement then made by the art of torpedo-boat construction. Besides these torpedo boats, there were five of the same kind, the Sagi and others, in course of construction when the war between Japan and Russia commenced.

In this period some submarine boats were in use in the Japanese Navy, but they were all purchased from foreign dockyards, and none had been built in this country before the Russo-Japanese War.

\section{Supplement}

The following chronological tables show the construction of warships, torpedo-boat destroyers and torpedo boats, of which record has just been made. 


\section{Chronological Table of Construction of Warships and Torpedo-Boat DESTROYERS}

(From the Sino-Japanese War to the Russo-Japanese War)

\begin{tabular}{|c|c|c|c|c|c|}
\hline Name & Kind and Class & Where Built & Make & $\begin{array}{c}\text { Displace- } \\
\text { ment (Tons) }\end{array}$ & $\begin{array}{c}\text { Date of } \\
\text { Completion }\end{array}$ \\
\hline Suma..... & $3 d$ class cruiser & Yokosuka Naval Arsenal & $\begin{array}{l}\text { Steel, twin, } \\
\text { steam }\end{array}$ & 2,657 & Dec., I 896 \\
\hline $\begin{array}{l}\text { Akashi ...... } \\
\text { Chihaya ... }\end{array}$ & Dispatch boat & “" & $\ddot{4}$ & $\begin{array}{l}2,755 \\
1,238\end{array}$ & $\begin{array}{l}\text { Mar., } 1899 \\
\text { May, }\end{array}$ \\
\hline Niitaka.... & 3d class cruiser & “ & “ & 3.366 & Jan., $\quad 1904$ \\
\hline Otowa.... & " " & T. “ & “" & 3,000 & Sept., 1904 \\
\hline Miyako.... & Dispatch boat & Kure Naval Arsenal & ““ & 1,772 & Mar., I 899 \\
\hline Tsushima... & 3d class cruiser & & “. & 3.366 & $\begin{array}{ll}\text { Aug., } & 1903 \\
\text { Feb., } & \text { I904 }\end{array}$ \\
\hline Harusame.. & 3 d class destroyer & Yokosuka Naval Arsenal & “” & 375 & June, I903 \\
\hline Murasame.. & " & & $\because$ & 375 & July, 1903 \\
\hline Hayatori... & “。 & “ & “" & 375 & Aug., 1903 \\
\hline Asagiri & & & “" & 375 & Sept., 1903 \\
\hline
\end{tabular}

Total: 8 warships; 4 torpedo-boat destroyers

a "Steel" denotes material used for the ship's hull; "twin" means twin screw; "steam," steam power.

Chronological Table of Construction of Torpedo Boats

(From the Sino-Japanese War to the Russo-Japanese War)

\begin{tabular}{|c|c|c|c|c|c|}
\hline Name & Class & Where Built & Material & $\begin{array}{l}\text { Displacement } \\
\text { (Tons) }\end{array}$ & $\begin{array}{c}\text { Date of } \\
\text { Completion }\end{array}$ \\
\hline 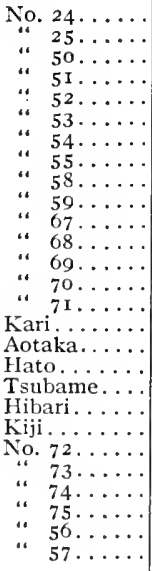 & 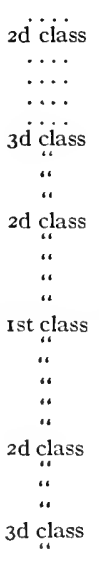 & 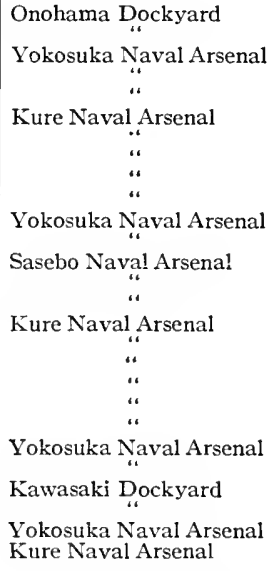 & 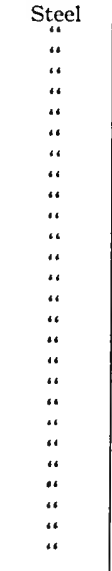 & $\begin{array}{r}78 \\
82 \\
52 \\
52 \\
52 \\
52 \\
52 \\
52 \\
53 \\
53 \\
94 \\
94 \\
94 \\
94 \\
94 \\
150 \\
150 \\
150 \\
150 \\
150 \\
150 \\
94 \\
94 \\
94 \\
94 \\
52 \\
52\end{array}$ & 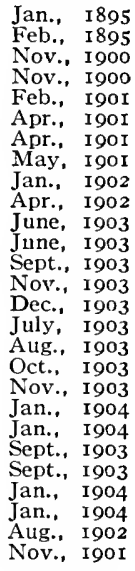 \\
\hline
\end{tabular}

Total: 27 torpedo boats 


\section{CHAPTER IV}

\section{FROM THE RUSSO-JAPANESE WAR TO THE PRESENT TIME}

The Russo-Japanese War was one of the world's greatest wars. On land the two engaging armies exceeded one million, the fighting line extended over nearly a hundred miles, the battlefields were stretched hundreds of miles, and the distance over which troops and provisions were transported from the two countries to the front reached in all some thousands of miles. On sea the tonnage of the modern and efficient fleets of the two countries totaled hundreds of thousands. The latest improved arms and ships used in this war were manipulated by the application of the newest arts, and consequently the experience obtained in the war in tactics and strategy was very great, which called forth the necessity of making many improvements in the manufacture of arms, ammunitions, ships, etc., and finally brought about a remarkable progress in military industries. Moreover, during and after this war, some increase in the number of military divisions and of special corps of the army was made, and in the navy in the number of its war vessels, so that after the war large quantities of arms and ships had to be manufactured, and besides not a few arms and ships needed repairing owing to the damages sustained in the war. All these requirements put the military factories of the army and navy in such an extremely busy condition for some years after the Russo-Japanese War that they were not able to complete the work, even by working at top speed; and they had to have private factories do a part on contract. The quantity and cost of the manufactures thus made reached unparalleled large amounts, and in fact the military industry has now become the center of the industry of this country, and the large sum of expenditures annually needed for the same is forming the great bulk of Japanese finance. 


\section{INDUSTRIES OF THE ARMY}

\section{Arms}

In the space of only the ten years that have elapsed since the Russo-Japanese War, there is a wide gulf in power between the arms made now by the experience obtained in the war and those used at that time. The following is a brief description of the principal arms:

(I) Magazine Rifles.- The infantry and cavalry rifles of the 3 oth year type used in the Russo-Japanese War were, as the result of the experience obtained in the war, improved in the mechanical parts of their tail body and bolt, and by the addition of a cover sheltering from the dust. These new rifles, which are still in use at the present time, were in May of the 39th year of Meiji (I 906) adopted as military rifles and named the infantry rifle of the 38 th year type and the cavalry rifle of the 38 th year type.

(II) Machine Guns.-Two different types of Hotchkiss machine guns were in use before the Russo-Japanese War; one with a traveling gun carriage and the other with a tripod; but in February of 40 Meiji (I907), only the latter type was adopted, with some alterations made in the gun, for the reason that it was the one most used in actual war and proved the most convenient to transport, as its carriage could be carried on horseback as readily as other portable materials. In June of the same year the adoption of the gun was officially confirmed, and it was named the machine gun of the 38 th year type, and is still in use.

(III) Quick-firing Guns.-In the quick-firing guns, both field and mountain, of the 3 Ist year type which had been used by the Japanese Army in the Russo-Japanese War, the experience of the war showed many points needing improvement, and consequently a new model was decided upon at the time when the adjustment of arms was being effected after the war, and manufacture was immediately begun. These guns were of a hydraulic buffer type, provided with the spring of recuper- 
ator, and the type was officially confirmed as a military gun in the 4oth year of Meiji (1907), being named the field gun of the 38 th year type, which is still in use.

The most important points of progress made in the guns were the increase of velocity of firing and the improvement of sight. The increase of the firing velocity produced more shooting power and made any frontal attack in the day time and in the open field very difficult. But as, on the contrary, it would limit activity of the army and especially would prove very disadvantageous in pursuit, if the activity of the supplying organ be not proportioned to the quick consumption of ammunition, a more careful consideration for the rear troops became necessary from the strategic point of view after the present discovery of the new firing method.

Improvement in sight made the artilleries of both the offensive and defensive armies take shielded positions in most cases, with the result that the suppression at the right time of the enemy's firing, to help the infantry's attack upon the enemy, became more difficult than before, and made cooperation of the infantry and artillery more necessary.

(IV) Transport Vehicles.--In the Russo-Japanese War every transport corps experienced many difficulties arising out of the defective construction of the transport vehicles of the 36 th year type, especially the delicateness of those wagons of the same year's type, which was very often the cause for the difficulty in their movement on bad roads. To overcome such difficulties, a two-wheeled vehicle for the pontoon was made on trial, and at the same time the two-wheeled vehicle of the 38 th year type already in use was improved by broadening as well as shortening its carriage and increasing the diameter of its wheels, and upon examination proved satisfactory. The regulation type of military vehicles was accordingly altered in January, 4r Meiji (I908), and the former of the above described new vehicles was called the second transport vehicle of the 39th year type and the latter the first transport vehicle of the 39 th year type. 


\section{Implements and Materials}

The term implements and materials used here is intended to mean the implements and materials for communication, railway, bridge building, and sanitary purposes; and we shall describe here all those except railway materials, of which mention will be made in a separate article under the heading of "Means of Communication on Land."

(I) Implements and Materials for Communication. Telegraph and Telephone.-The first military use of the telegraph in Japan was made in the Satsuma Rebellion of the Ioth year of Meiji (I877). When on February I9 of the same year the order to punish the Satsuma rebels was issued, a number of temporary bands were formed to take charge of the military telegraph, and were sent out with telegraphic instruments, and at the same time some of the officials of the Industrial Department were sent out to take charge of the military communications between the various bodies. The distance over which the telegraph was used aggregated $204 \mathrm{ri}$ and io cho (or about 500 miles) in length, and 53 stations were used. Although in Japan in those days there was an army of six garrisons, arranged into many classes, as infantry, cavalry, artillery and transport, there was no telegraph corps organized, and the instruments and wires used for the military telegraph had to be imported. The civil war, in which the advantage of using the telegraph was decidedly proved, brought a change in the military arrangements, and on February Io, I3 Meiji (I880), a military telegraphic corps was organized, and all implements, materials and carriages for the military telegraph were stored in its magazine. On May 7, I9 Meiji (I886), the telegraph instruments were attached to the jurisdiction of the battalion of engineers, and in the next year the military telegraph corps having been disorganized, the battalion of engineers of every division were made to study matters of the field telegraph corps. Although the telegraph corps engaging in the field operations in the Sino-Japanese War assisted strategy in no small degree by the use of its instruments and materials, 
many defects were found. Therefore, after the war the task of improving those instruments and materials was undertaken and in March, 33 Meiji (I900), all of the drawbacks were repaired. The principal one of the improvements was the transportation of telegraphic instruments and materials by carriage instead of on horseback, as was the case up to that time. The newly repaired instruments and materials found opportunity for actual use in the North China affair that took place in June of the same year, when the field telegraph corps joined the line of battle. With the advance of the Fifth Division, a military line of 200 kilometers was installed, from West Taku to Peking, affording opportunity for the newly repaired instruments and materials to be put to practical use. In October, 35 Meiji (I902), the telegraph educational battalion was created to educate clerks and study the improvement of instruments and materials.

In January, 37 Meiji (I903), the means of communication for cavalry were regulated, by which the use of the telephone by the cavalry as a military implement was first introduced.

In February of the same year the Russo-Japanese IVar opened, and the cavalry was sent out with telegraphic apparatus and the engineering corps fitted out with the telephones used for training in peace time. Later on in the war telephones were used by the infantry, also telephone companies were organized by the headquarters of the divisions for communication with subordinate commanders out on the field; further, in October, a temporary telephone corps was organized, when, with the extension of the fighting line of the army out in Manchuria, it was necessary to bring the headquarters of the different armies into direct connection with the general headquarters.

In the Russo-Japanese War, in which the fighting line extending over some hundred miles made communication between the troops in the front and the rear very important, the telegraph corps in the field service always acted quite in harmony with the movement of the army and the requirement of the strategy with fair success. The length of the lines put up 
by the telegraph corps during the war reached $\mathbf{5 2 , 8 3 2}$ kilometers, and the number of communications exchanged during the same time, 4,694,319, which shows how indispensable the telegraph and telephone services are for military purposes. However, the instruments and materials used at the time were by no means perfect, hence the repeated regulations and improvement even after the war.

Wireless Telegraph and Telephone.-Although the necessity of the wireless telegraph for military purposes was recognized shortly after its invention, it was not until 42 Meiji (I909) that any special organ for its study and investigation was formed by the Japanese Army. The work of study and investigation was then commenced by the committee for the same under supervision of the war minister, and is still in progress, at a yearly expense of 70,000 yen. The wireless telephone is being studied chiefly by the navy, but is yet being used in the army.

As to the manufacture of instruments and materials of communication, about one-third are made in the military arsenals and the rest by private manufacturers, the cost of the same for each of the last three years being as follows:

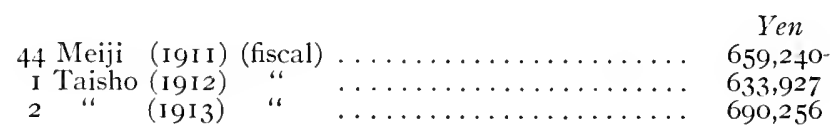

(II) Materials for Bridging.-When at the beginning of Meiji Western learning was adopted, the French system was followed in the organization of the army, by which in the 6th year of Meiji ( 1873 ) six garrisons were established, arranged in infantry, cavalry, artillery, engineer and transport corps, and to the engineer corps the Pirago trestle bridges were assigned as materials for military bridging, but no materials of portable pontoon bridges for field troops had yet come into regular use. When on account of the Korean affair in 17 Meiji (I 884) the fixing of regular engineering implements and materials to be assigned to the outgoing troops was found necessary, the en- 
gineers' and sappers' implements were roughly selected for the Engineer Division, and thereby the necessary implements and materials to be shipped to the front were fixed. But as the materials for bridging were in those days of too great a size to admit of transportation to a foreign country or even inside the country, these materials were made at the seat of war whenever the need arose. This work was certainly a hard task for the men of the Engineer Division, and consequently improvement of the materials was deemed quite urgent. In the next year, after hard toil and application, a design of an iron boat was made, and a number of model boats was ordered from the Tsukiji Dockyard, which completed the work in two months. These iron boats were built of iron plates of the thickness of 5 rin (about $\mathrm{I} .5 \mathrm{I} 5 \mathrm{~m} . \mathrm{m}$. ), each measuring 6 meters in length, I.50 meters in breadth, and o.80 meters in depth, and weighing I 40 kan (525 kilograms).

In March, I9 Meiji (I886), the new iron boat was adopted after due trial, and later, selection having been made of the various materials to suit the boat, the official set of materials for the military-bridge column was fixed. These materials were in those days carried as a rule by pack horses; and it was they that were used for the crossing of Yalu River and on other occasions in the Sino-Japanese IVar, and facilitated the movement of the field forces. After the war, the power of resistance of these materials was not quite equal to the increased weight of materials used by the field armies, and they were kept barely serviceable by the addition of a number of cross beams and other means of strengthening. In 33 Meiji (I900) they were altered to a carriage transportation system, but before any actual improvement was effected, the Russo-Japanese War arose, and though hopelessly unable to meet the requirements of the moment, they were again put to service in the crossing of the Yalu and the like, and fortunately enough, with the aid of the practice of "bridging with applied materials," succeeded in getting the field armies over without interruption.

Such being the state of bridging materials, work was begun 
immediately after the war, to improve them, with the result that a new set of bridging implements and materials was officially fixed in August, 42 Meiji (I909).

All bridging materials are made at the arsenals, and at present the greater part of them are being made at the Atsuta arms factory. The expense of their manufacture in three recent years is as follows:

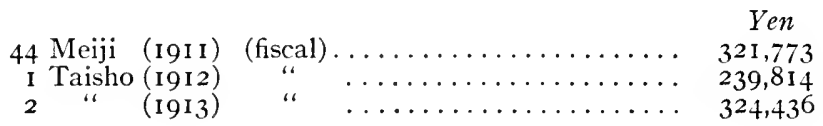

(III) Medical Materials.-In 29 Meiji (I 896) the Central Medical Material Depot of the army was established in Tokyo. Its duty is the custody, purchase, manufacture, exchange, repairing, etc., of reserve medical materials and model articles; it also carries on the testing of medical materials.

In 3I Meiji (I898) the Central Medical Material Depot of the army was closed and the Medical Material Depot of the army was set up in Tokyo, the business of which consists in the manufacture, purchase, storing, supply and qualitative examination of model medical and veterinary materials, special medical articles, and articles for use in war, as well as in purchases and supply materials for troops stationed abroad.

In 42 Meiji (I909) the trial manufacture of tablets, extracts, ointments, plasters, powders, compounds of soap, fluid disinfectants, disinfected bandages, was commenced.

In 44 Meiji (I9II) a trial making of surgical knives was commenced. At present, the factory contains one tablet making room, one plaster room, one powder medical room, one disinfected bandage room, one forging room and one finishing house; the hands engaging in the work are thirtyfive for the making of the special preparations and fourteen for knife making; the principal implements in use are four tablet makers, six desiccators, six double pans, two rollers, four pulverizing machines, one lathe, one milling machine, one wheel grinder, one plating machine, two bellows, etc.

By the following tables comparison by the year may be 
made, of different years' productions of the manufactures, and of manufacturing expenditures:

Comparative Table of Amounts of Manufactures Produced in Three Successive Years

\begin{tabular}{|c|c|c|c|c|c|c|}
\hline \multirow{2}{*}{ Fiscal Year } & \multicolumn{2}{|c|}{$\begin{array}{l}\text { Special Preparation } \\
\text { of Medicines }\end{array}$} & \multicolumn{2}{|c|}{ Consumable Articles } & \multicolumn{2}{|c|}{ Knives } \\
\hline & Sort & Number & Sort & Number & Sort & Number \\
\hline I9I I & 59 & I $3,798,54 \mathrm{I}$ & 5 & I02,896 & 77 & 3,543 \\
\hline I912. & 64 & I $2,650,320$ & 7 & I $34,49^{8}$ & 83 & 5,998 \\
\hline I9I 3. & 48 & I $7,705,100$ & 5 & 93,250 & $5 \mathrm{I}$ & $3, \mathrm{I} 8 \mathrm{I}$ \\
\hline
\end{tabular}

Comparative Table of Manufacturing Expenditures in Three SUCCESSIVE YEARS

\begin{tabular}{|c|c|c|c|c|c|c|c|}
\hline $\begin{array}{l}\text { Fiscal } \\
\text { Year }\end{array}$ & $\begin{array}{l}\text { Wages of } \\
\text { Workmen }\end{array}$ & Coal & $\begin{array}{l}\text { Electric } \\
\text { Motive } \\
\text { Power }\end{array}$ & Gas & $\begin{array}{l}\text { Water } \\
\text { Rate }\end{array}$ & $\begin{array}{c}\text { Implements } \\
\text { and } \\
\text { Miscellaneous } \\
\text { Expenditure }\end{array}$ & Total \\
\hline & Yen & Yen & Yen & Yen & $Y e n$ & Yen & Yen \\
\hline I9I I & $5,748.76$ & 836 & 410.88 & $7 \cdot 37$ & 99.84 & $5,439.8 \mathrm{I}$ & I 2,542 . \\
\hline I & $7,041 \cdot 32$ & 836 & 315.37 & $43 \cdot 45$ & 128.16 & 4,285 . & $12,650.0$ \\
\hline I 3 & 8,248 I 5 & 843 & $35 \mathrm{I} . \mathrm{I} 2$ & $47 \cdot 79$ & 150.06 & $14,009.68$ & $23,649.80$ \\
\hline
\end{tabular}

\section{Ammunition and Ignition Tools}

During the war of 37 and 38 of Meiji (1904, I905), many cases of nonignition were found among the base fuses for coast guns, and therefore a partial alteration of the fuse was made.

During the same war a base fuse of the common siege gun shells, in which yellow powder burster was used, was adopted for regular use. The same is called the Krupp base fuse.

After the Russo-Japanese War, in 38 Meiji (I905), the compound fuse of the 38 th year system was fixed as regular. It was generally called the 35 -second compound fuse, because of its consuming time of 36 seconds and more.

In $38 \mathrm{Meiji}$ the percussion fuse of the 38 th year system was fixed as regular, and at the same time the percussing apparatus 
of all base fuses was altered to the same make as that of the 38 th year.

As the advance in ammunition and ignition implements has greatly increased their efficiency, more defense works and utilization of ground objects (i.e., a building, tree, mound, etc.) in the battlefield has become necessary, and especially the increase of their destructive and penetrative powers has made the improvement of the defensive quality of all defense works on land and of that of warships more necessary.

\section{Means of Communication on Land}

Among means of communication on land are to be reckoned the telegraph, telephone, railway, bicycle, automobile, etc., but of the telegraph and the telephone record has already been made under "Implements and Materials" for communication, and therefore nothing will be said of them here. Of bicycles, mention will be omitted, as no cyclist corps has yet been organized, and its use is comparatively small, although the use of the bicycle had been recognized as necessary in war time and is at present under study, including the use of the bicycle in the Sino-Japanese IVar.

(I) Railway Materials.-At the end of 29 Meiji (I896) a railway battalion was organized for the first time, and the appliances and materials for the use of the battalion were officially fixed. In the North China affair in 33 Meiji (I900), the temporary railway battalion had an opportunity of putting to practical use the above regulation appliances and materials by engaging in the repairing and running of a broad gauge railway between Tangyu and Peking (about 6I kilometers). After that affair the opinion of the urgency of improving railway appliances and materials became prevalent among the authorities, and finally in May, 36 Meiji (I903), an alteration was effected.

During the war that occurred in the following year (37 to $38 \mathrm{Meiji}$ ), the temporary railway battalion was engaged, by using the new regulation appliances and materials supplemented with some other necessary ones, in the construction of 
under parts of a broad gauge railway of about 65 kilometers between Seoul and Gishu, the construction and running of a $2 \frac{1}{2}$ feet light railway of the Ampo line (mainly a line of about I 70 kilometers in the line built in the first period, from Antunghsien to Hsiamatang), the railway construction in the vicinity of Mukden and Hunhopas, and the construction and running of a light railway of about 62 kilometers between Mukden and Sinminting, and this served the purpose of the field armies. But in this war, from various circumstances, it was unavoidable for the battalion to use oddly-mixed appliances and materials; and though of materials used by the Hand Truck Railway Division, which was temporarily organized during the war, the most were I2-pound rails and hand trucks which were good; the other miscellaneous things that were carried with the party were not free from defects, as they had not been studied beforehand. After the Russo-Japanese War the Railway Material Department was attached to the railway regiments, and at the same time the latter was put under the jurisdiction of the Bridge Headquarters of the Communication Corps. While changes stated above have been undergone, no alteration has on the whole been made in the essential part of materials like rails and railway points since the organization of the railway battalion.

The making and repairing of these railway materials have been carried on at the Railway Material Department in the railway regiment. But at the present time, repairing is mainly being done, no new materials being made except small appliances, and whatever is wanted being usually purchased of private manufacturers.

The statistics of motive power, workmen and expenditure of the factories of the Railway Material Department are as follows:

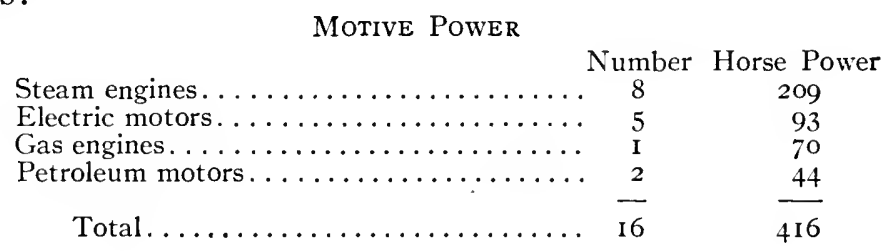




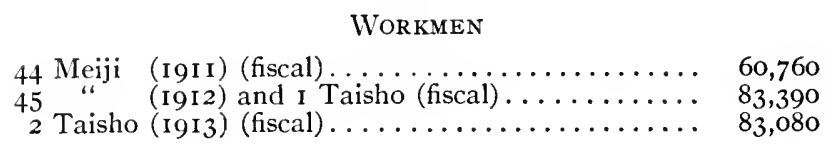

EXPENDITURE

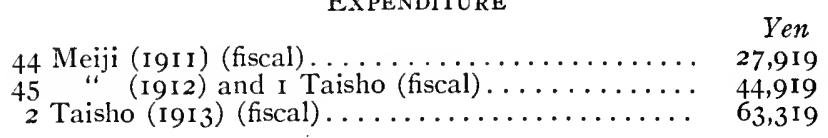

As may be seen from the large increase of the expenditure shown above, the department is enlarging its plan of work every year.

(II) Automobiles.-It was 39 Meiji (1906) when the Japanese Army began the study of automobiles.

In 40 Meiji (1907) a freight automobile of the four-ton class was purchased of an automobile company in France, and in $4 \mathrm{I}$ Meiji (1908), two more purchased of the Snaidel Canay Company, also of France. After several experiments with these, in 43 Meiji (19I0), two automobiles for military transportation service were made on trial at the Osaka Arsenal, which was the beginning of automobile making in the Japanese Army.

In 43 Meiji, a pack automobile was bought from the Thornycroft Company in England and one from the Gaggenau Company in Germany, and a study was made of the construction, design, use, handling, etc., of automobiles. In 44 Meiji (I9II) four "b" trial freight automobiles were made at the Osaka Arsenal, entirely after designs of the Japanese Army.

In June, 2 Taisho (I9I3), four "c" trial freight automobiles (four-ton class) and two " $\mathrm{d}$ " trial freight automobiles (threeton class) were made at the arsenals of Tokyo and Osaka. Although no figures relating to workshops, workmen, etc., for the manufacture of the automobiles can be given in any separate form, owing to the fact that automobiles are made in the arsenals together with other arms, their manufacture is at any rate annually increasing, as the necessity is increasing more with the progress of other war implements. At present a yearly sum of about 300,000 yen is being expended for study, manufacture and repairing. 


\section{Implements for Horses}

By the expression "implements for horses" we mean the harness for riding horses of commissioned officers and of cavalry, artillery and transportation soldiers, that for draught and pack horses of artillery, the furniture for draught and pack horses of the transport corps, horseshoeing implements, cleaning instruments for horses, etc. Of these articles the harness for riding horses of commissioned officers is to be supplied by the officers themselves, so the arsenal makes only a little that is needed for mobilization. The manufacture of the harness for other riding, draught and pack horses is not small either in quantity or value, but as the cost is not great compared with the manufacture of either small arms, guns, ammunition or the like, it is not important as a military industry. Above all, these things form a part of "arms" and may well be considered under that head, and any particular account given of them independently would only be superfluous. Therefore, description will be made here of only the changes and development of the furniture for draught and pack horses for transportation services and matters relating to horseshoes, which are comparatively not akin to regular arms. The whole interval from the Restoration to the present time has been included.

(I) Harness for Draught and Pack Horses of the Military Train.-The draught-horse saddle used for the provision wagon of the Arisaka style, which was an improved form of horse-drawing provision carriage made on trial in $\mathbf{} 8$ Meiji (I885) and was in use until 23 Meiji (I890), was a saddle of a small size like that for the off-horse of the artillery, and was the regulation draught-horse harness at the same time as the fixing of the official forms of the provision wagon and the wagon of the ammunition battalion.

The harness for the pack horses of the transportation corps in use in the early part of Meiji when the transportation corps was first organized, was one that was made by altering the common pack-horse saddle on advice given by Tersan, a 
French cavalry captain in the employment of Japan, and was therefore called the Tersan transportation pack-horse saddle, and was of no fixed form. The Ordnance Committee of that time made a comparative study between a saddle designed by the Osaka Branch Arsenal and the Tersan saddle, and as the result obtained a form which in its general outline followed the Osaka Arsenal's design, but was better, and was in I3 Meiji (I 880) fixed as official. This was called the pack-horse harness of the transportation corps of the I3th year form.

This harness of the 13 th year form was found from practical use, to be not only imperfect in some respects but useless for loading with unaccustomed articles, such as the heavy and the light baggage of infantry and the engineer corps, and medical materials. Therefore, in 19 Meiji (I886), a form of a pack saddle was made on trial, using as basis a common pack saddle in use among the people; but, though it was tried with satisfactory results in an expedition made for the purpose in $\mathbf{2 I}$ Meiji ( 1888 ), some defective points were found in its construction after practical use by different companies of soldiers, and therefore, inistead of this saddle, one that was tried in a previous year by the first battalion of the transportation service was adopted in $2 \mathbf{I}$ Meiji (I888), being light in weight and easy of manufacture. This was called harness No. I for the transportation pack horse.

Taught by experience in the Sino-Japanese War and by the use of the provision wagon since that time, an alteration was made in the regulation form of the harness for the transportation pack horse in 33 Meiji (1900), the same having been based upon advice given in $3 \mathrm{I}$ Meiji ( 1898 ) by the chief of the Tokyo Head Ordnance Department and made after due study and trial by the Ordnance Committee. The new harness was called the harness for the transportation pack horse of the $33 \mathrm{~d}$ year form.

As the result of the experience in the North China affair in 33 Meiji (I900), the work of improving wagons and draughthorse equipments was taken up, and a committee of investigation for the improvement of the same was appointed in 35 Meiji (1902). After some trial makings and testings, the of- 
ficial forms of provision wagons and draught-horse equipments were fixed, the latter being called for the harness the transportation draught horse of the 36 th year form.

It was found in the war with Russia in the 37 th and 38 th years of Meiji (1904, 1905) that the above 36 th year draughthorse saddle was defective, in that it could not be used as a pack saddle where difficulty should arise for the wagon to pass and the horse be required to carry the load on its back. Studies were made to obviate this drawback in the saddle, and in $4 \mathrm{I}$ Meiji (I908) the form was altered into a new one called the harness for the transportation draught horse of the 38 th year form.

All of the above-mentioned horse harness is made at the gun accessories factory of the Tokyo Arsenal, the factory for implements and materials of the Osaka Arsenal, the Moji weapon manufactory, etc. Its manufacturing will be included in the expenses for arms manufacture hereafter shown.

(II) Horseshoes. - With the organization of the Japanese Army after the Restoration, in which European systems were followed, the European method of shoeing war horses with a horseshoe was also adopted. Men were educated for horseshoeing foremen in the Military Veterinary School, and they in turn educated the farrier soldiers in the cavalry, field artillery and transportation corps, so that ordinary horseshoeing of war horses was done by them, while the horseshoes for use in ordinary times that could not be made by the different troops and those for use in mobilization in war time are made at the gun accessories factory in the Tokyo Arsenal, and if necessary a part of the work is given to private farriers by contract.

The amount of horseshoes required in the fiscal year of 2 Taisho (1913) and the amounts manufactured at different places are as follows:

Amount required, 435,600 sets, value 200,300 yen (including the value of nails).

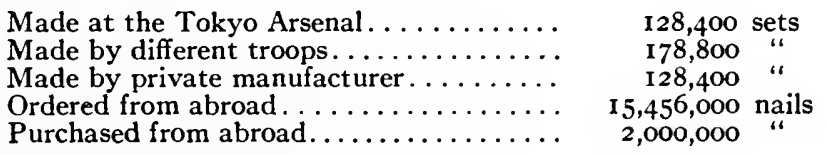


The horseshoeing implements are made at the gun accessories factory of the Tokyo Arsenal and the factory for implements and materials of the Osaka Arsenal. The value of the horseshoeing and clipping machine with which the different corps were furnished the first time is $122,84 \mathrm{I}$ yen, and their annual upkeep expense, 68,4I5 yen.

We have now finished our description of the general outline of the different branches of the manufacturing industry performed by the Tokyo and the Osaka Military Arsenals; to this we add, with the object of giving an idea of the development made by the industries in those arsenals since the RussoJapanese War and of their present plan and condition of work, a statement containing the working expenses, itemized, revenue and fixed capital about the time of the Russo-Japanese War, also the cost of raw materials purchased, number of workmen, and their wages in the first fiscal year of Taisho (I9I2) of the same arsenals.

Expenses and Revenue of Operation

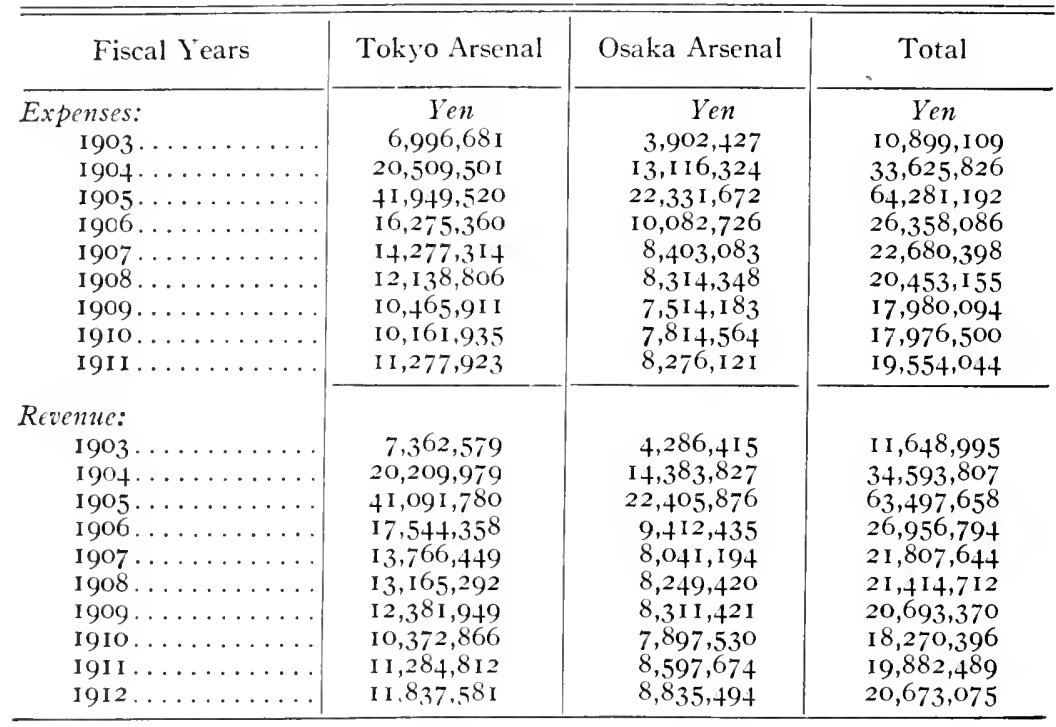


EXPENSES FOR RAW MATERIALS

\begin{tabular}{|c|c|c|c|}
\hline Material & Tokyo Arsenal & Osaka Arsenal & Total \\
\hline $\begin{array}{l}\text { Metal. .......... } \\
\text { Leather. . . . . } \\
\text { Timber ....... } \\
\text { Powder material. } \\
\text { Miscellaneous... }\end{array}$ & $\begin{array}{c}Y e n \\
\mathrm{I} 365,1 \mathrm{I} 8 \\
\mathrm{I}, 233,566 \\
967,707 \\
\mathrm{I}, 067,196 \\
875,808 \\
\end{array}$ & $\begin{array}{c}Y e n \\
1,962,648 \\
1,183,840 \\
812,057 \\
570,815 \\
670,056 \\
\end{array}$ & $\begin{array}{c}\text { Yen } \\
3,327,767 \\
2,417,406 \\
1,779,765 \\
1,638,011 \\
1,545,865\end{array}$ \\
\hline Total........... & $5,509.395$ & 5.199 .416 & $10,708,814$ \\
\hline
\end{tabular}

Detalls of Revenue from Operation of Arsenals

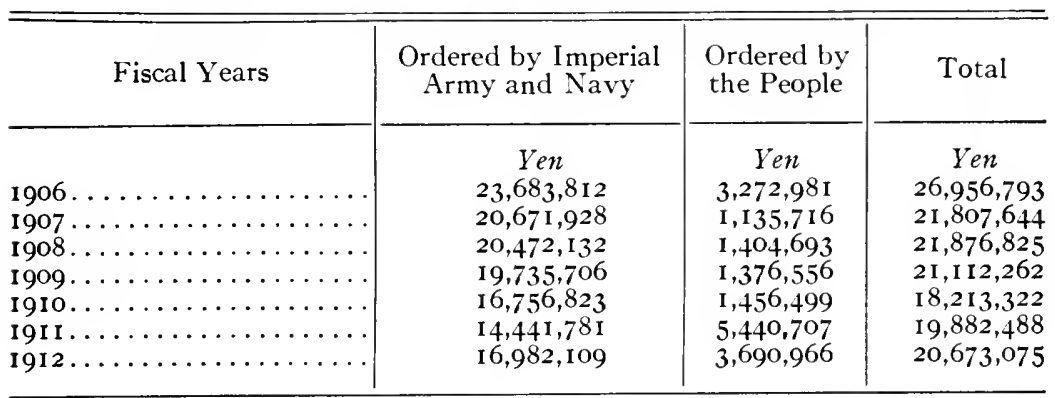

Workmen Engaged in Arsenals and Wages at End of Fiscal Year 19 Ir Workmen

\begin{tabular}{|c|c|c|c|c|c|c|}
\hline \multirow{2}{*}{ Arsenals } & \multicolumn{3}{|c|}{ Number } & \multicolumn{3}{|c|}{ Working Number for a Year } \\
\hline & Male & Female & Total & Male & Female & Total \\
\hline $\begin{array}{l}\text { Tokyo ..... } \\
\text { Osaka.... }\end{array}$ & $\begin{array}{r}14,398 \\
9,688\end{array}$ & $\begin{array}{r}2,969 \\
792\end{array}$ & $\begin{array}{l}17,367 \\
10,480\end{array}$ & $\begin{array}{l}4,075,5^{82} \\
3,123,499\end{array}$ & $\begin{array}{l}804,753 \\
204,370\end{array}$ & $\begin{array}{r}4,880,335 \\
3,327,869 \\
\end{array}$ \\
\hline Total & 24,086 & 3,761 & 27,847 & $7,199,081$ & $1,009,123$ & $8,208,204$ \\
\hline
\end{tabular}

Wages for a Year

\begin{tabular}{|c|c|c|c|}
\hline Arsenals & Male & Female & Total \\
\hline $\begin{array}{l}\text { Tokyo } \ldots \ldots \ldots \ldots \ldots \ldots \\
\text { Osaka } \ldots \ldots \ldots \ldots \ldots\end{array}$ & $\begin{array}{l}3,569,139 \\
2,367,520\end{array}$ & $\begin{array}{r}329,593 \\
68,229\end{array}$ & $\begin{array}{l}3,898,732 \\
2,435,749\end{array}$ \\
\hline Total ...... & $5,936,659$. & 397,822 & $6,334,48 \mathrm{I}$ \\
\hline
\end{tabular}




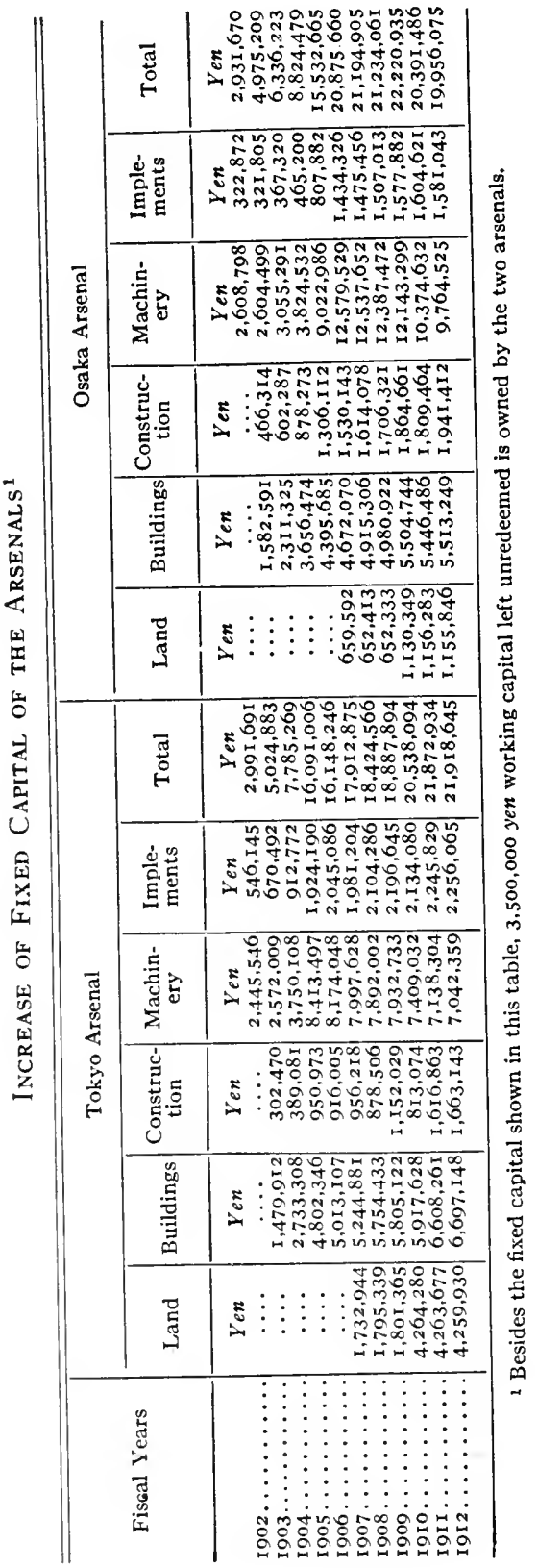


The principal articles being made at the factories in the Tokyo and Osaka Arsenals at present are as follows:

Armament Manufactures, Tokyo and Osaka

\begin{tabular}{|c|c|c|c|}
\hline Arsenals & Factories & Locations & Principal Articles \\
\hline Tokyo & $\begin{array}{l}\text { Small arms factory } \\
\text { Gun accessories factory } \\
\text { Delicate instrument } \\
\text { factory } \\
\text { Ammunition factory } \\
\text { High explosive factory } \\
\text { Itabashi powder mill } \\
\text { Meguro powder mill } \\
\text { Iwabana powder mill } \\
\text { Atsuta arms manu- } \\
\text { factory }\end{array}$ & $\begin{array}{c}\text { “ } \\
\text { Oj } \\
\text { Itabashi } \\
\text { Meguro } \\
\text { Iwabana } \\
\text { Nagoya }\end{array}$ & $\begin{array}{l}\text { Small arms, pistols, bayonets, machine rifles } \\
\text { Sabres, harnesses, ammunition pouches, arms } \\
\text { of leather or hemp, various castings, shells, } \\
\text { tools for artificers, tools for firing, ordnance } \\
\text { maker, horseshoes, canteen, implements for } \\
\text { horseshoe making. etc. } \\
\text { Field glasses, range finders, training gears, } \\
\text { communication instruments, electric arms } \\
\text { Substantial and empty cartridges for rifles } \\
\text { Detonators, fuses, ignition tools } \\
\text { Powder, explosive compounds } \\
\text { Powder } \\
\text { Powder, explosive compounds } \\
\text { Carriages, implements, materials, etc. }\end{array}$ \\
\hline Osaka & $\begin{array}{l}\text { Ordnance factory } \\
\text { Shell manufactory } \\
\text { High explosive factory } \\
\text { Iron works } \\
\text { Factory for implements } \\
\text { and their materials } \\
\text { Cartridge factory } \\
\text { Uji powder mill } \\
\text { Moji weapons manu- } \\
\text { factory }\end{array}$ & 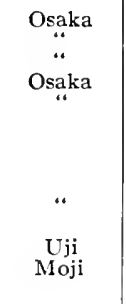 & $\begin{array}{l}\text { Guns } \\
\text { Shells } \\
\text { Detonators, fuses, powder } \\
\text { Castings, forged articles, steel as material } \\
\text { Carriages, harnesses, ammunition pouches, } \\
\text { arms of leather or hemp, tools for artificers, } \\
\text { tools for firing, ordnance maker, materials } \\
\text { for implements, implements for making } \\
\text { horseshoes } \\
\text { Cartridges for guns, castings of alloys, lunch } \\
\text { boxes, etc. } \\
\text { Powder, explosive compounds } \\
\text { Carriages, leather implements, etc. }\end{array}$ \\
\hline
\end{tabular}

\section{Clothing and Equipment}

In this article, on the same ground as stated above, a summary of the history from the starting of the industries up to the present is given.

(I) Clothing.--The manufacture of military clothing was begun in July, 2I Meiji (I888), when the Senju woolen cloth factory, making woolen cloth as the material for clothing as its principal work, was removed from the jurisdiction of the Department of Agriculture and Commerce to that of the War Department. But the labor in this line was not so confused as in the case of the arms industry, and at the beginning of the work the amount of products was too small to be given separately for several periods. The military clothing department, in charge of shoemaking, tailoring, etc., as its principal occupations, was established in 35 Meiji (I902), only 
a little more than a year before the Russo-Japanese War, and therefore there was no particular work performed in the same department which is worth mentioning under the separate heads of "before" and "after" the same war. For the sake, therefore, of economizing space in this subdivision is given the outline of the history since the starting of work of these two factories and a general view of the manufacture performed there last year.

(a) Woolen Cloth Manufacture.-The site of the Senju woolen cloth factory was placed at Minami-gumi, Senju, Kitatoshima District, Tokyo Prefecture, in June, Io Meiji ( 1877 ); in July construction was begun, and in September, I2 Meiji (I879), work was started therein. The factory, which had been at first under the jurisdiction of the Department of Civil Affairs, was removed to that of the Department of Agriculture and Commerce when the latter was established, and since July, 2 I Meiji ( I 888), has been administered by the War Department.

The factory, as the leader and an instructor of the same industry carried on by the people, encouraged the development of the manufacture, because in the days when that factory was established Japan in order to meet all her demands for woolen cloth relied entirely upon imports, and had no such enterprise. When in 19 Meiji (1886) the style of military clothing was altered and it was decided that the clothing for non-commissioned officers and soldiers should be made of woolen cloth, the demand was suddenly increased and the manufacture thereof was committed to the chief user of woolen cloth, the military, which has mainly engaged in manufacturing for itself. Thereafter the work was enlarged as woolen cloth was increasingly demanded for the military service, and as a result, the old factories were extended and new ones, artificial woolen factories for utilizing waste products, were established, all of which perfected the arrangement of the work. The manufacture of the cloth of dressed wool for the summer uniforms of officers was commenced, which was followed by felt making undertaken for the first time for the purpose of utilizing waste products. 
This factory is, to be sure, the pioneer of the mechanical industry in Japan which, at that early time when the industry of Japan was yet in its infancy, was provided with motive engines, spinning machines, power looms, etc. The factory warmly received visitors who came to obtain a view of the only factory of its kind in those days, and, aiming at kindness in guidance and explanation, and endeavoring to instill the knowledge of the work, it contributed not a little to the diffusion of the industrial idea in both a direct and an indirect manner. As stated above, the factory was established at a time when, although the demand for woolen cloth had gradually increased since the Restoration of Meiji, the country had no woolen industry, and necessarily imported all such articles. In those days things were in such a condition that no work demanding capital and knowledge could be developed without the help and encouragement of the government. This is the reason why the manufactory as the leader in the work at the time of its establishment, by showing a model to the people, was devoting itself to the development of the same work. As the perfect development of the woolen cloth manufacture necessitates a home supply of wool, sheep farming was widely encouraged among the people. But the result of the enterprise was very unfortunate. While thereafter the demand of the military for woolen cloth increased more and more, there was no popular enterprise in existence, and so the factory, upon its removal to the jurisdiction of the War Department, diligently endeavored to advance the work by manufacturing military woolen cloth as its principal service. Afterwards the woolen industry sprung into existence among the people, and so the factory left not only the woolen cloth needed by the people which had been supplied by the same factory as its subsidiary work, but also a part of the military woolen cloth, to private manufacture, and thus encouraged the development of the work among the people. On the other hand, the equipment of the factory, the selection of the machines, the training and distribution of the workmen, and instruction in the art were perfected as much as possible. Since the factory 
was established, thirty-four years have elapsed, and the number of workmen employed in this period has amounted to some ten thousand, although it is difficult to give the exact number of those who have been employed or dismissed. And how frequently the workmen were changed is inferred from the fact that about half of the present workmen are those who have entered the service during the last three years. Of those who leave their positions, there are not a few who are old, disabled or sick and too weak to work, while there are many who have obtained employment in factories among the people because of the skill gained at the government factory. This is proved by the fact that the withdrawal from service of the workmen on the motive engine has amounted to the largest number because of their being available for any part needing mechanical art. Those who engage in spinning, webbing, etc., may be hired for the spinning of cotton muslin, to say nothing of woolen cloth manufacture. It is also a matter of course that the workmen engaged in the woolen cloth manufacture were welcomed, because of their experience in the art, by factories engaging in the same manufacture. In these several ways the factory, from its establishment up to the present time, has benefited in no small degree the industry at large.

General Vieiw of the Manufacture at Present

Fixed capital.

Working capital.

Number of factories.$\cdots \ldots \ldots \ldots \ldots \ldots \ldots \ldots \ldots \ldots \ldots \ldots \ldots \ldots$

Motive powers (16):

Steam engines $(7) \ldots \ldots \ldots \ldots \ldots \ldots \ldots \ldots \ldots \ldots \ldots$ h. p.

Dynamos driven by steam power $(5) \ldots \ldots \ldots \ldots \ldots .605$

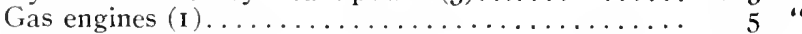

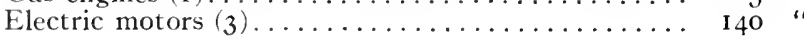

$1,901,521$ yen I, $, 000,000$

9 principal ones

I5O4 h. p.

Forty-eight officers and clerks, 57 employes for miscellaneous affairs, 474 males, 459 females, 933 workmen in all.

Coal consumed during a year, I 8,967 tons.

The following table shows the amount of the manufactures, expenses of and revenue from the work and the value of the products: 


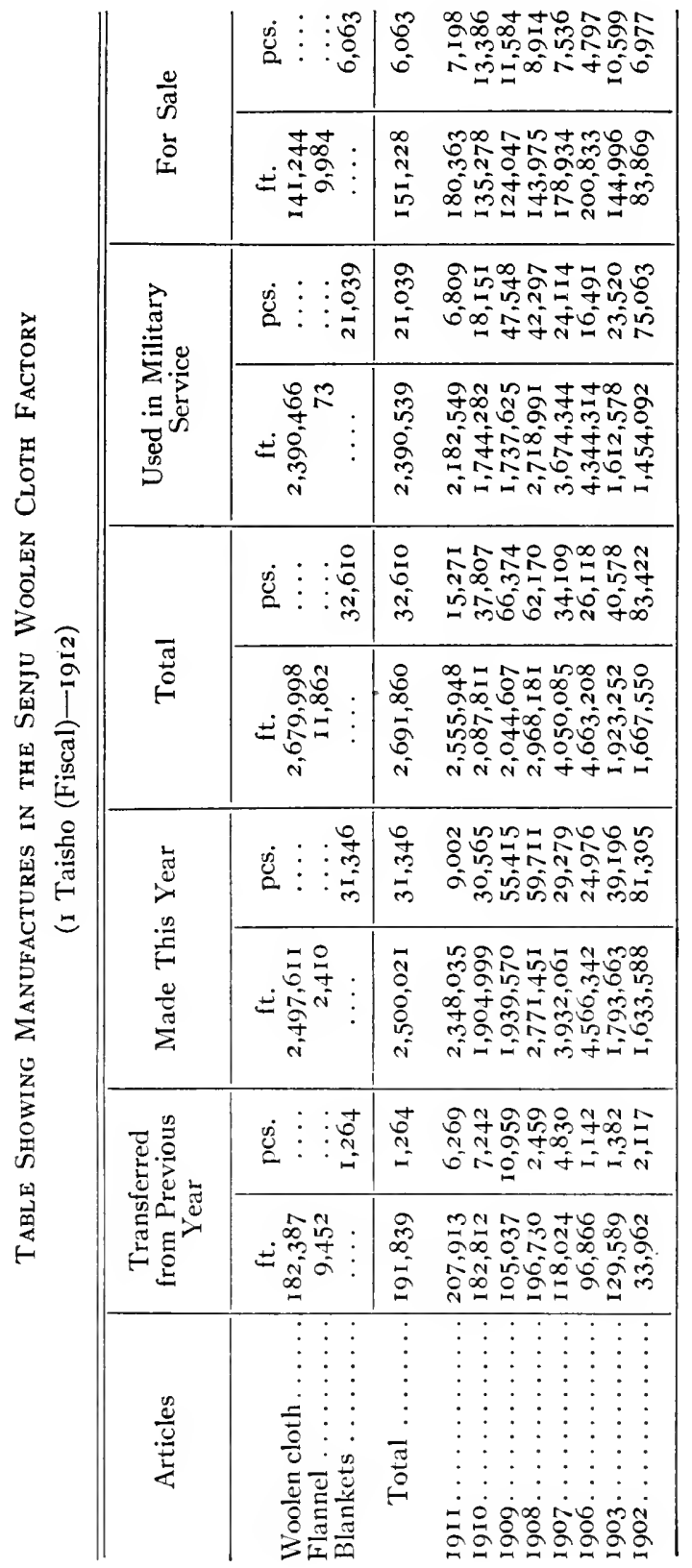


Expenditures and Receipts for and from Work in the Senju Woolen CLOTH FACTORY

\begin{tabular}{|c|c|c|}
\hline Fiscal Year & $\begin{array}{l}\text { Expense of } \\
\text { Operation }\end{array}$ & $\begin{array}{l}\text { Revenue from } \\
\text { Operation }\end{array}$ \\
\hline & $\begin{array}{c}Y e n \\
1,65^{8,280}\end{array}$ & $\begin{array}{c}Y e n \\
13,228,867\end{array}$ \\
\hline$\ldots \ldots \ldots \ldots \ldots \ldots \ldots \ldots \ldots$ & $4,502,915$ & $39,141,899$ \\
\hline$\ldots \ldots \ldots \ldots \ldots \ldots \ldots \ldots \ldots \ldots$ & $3,595,082$ & $67,035,290$ \\
\hline$\ldots \ldots \ldots \ldots \ldots \ldots \ldots$ & $3,66 \mathrm{I}, 015$ & $30,766,399$ \\
\hline 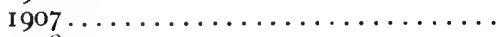 & $3,415,7 \mathrm{I} 3$ & $25,173,997$ \\
\hline 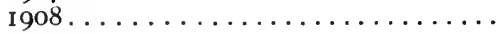 & $2,687,144$ & $24,133,867$ \\
\hline$\ldots \ldots \ldots \ldots \ldots \ldots \ldots \ldots$ & $2,248,182$ & $23,040,116$ \\
\hline$\ldots \ldots \ldots \ldots \ldots \ldots$ & $2,116,934$ & $20,526,263$ \\
\hline$\ldots \ldots \ldots \ldots \ldots \ldots \ldots \ldots$ & $2,167,217$ & 22 , I I I 49 I \\
\hline
\end{tabular}

Value of Products of the Senju Woolen Cloth Factory

\begin{tabular}{|c|c|c|c|c|c|c|}
\hline \multirow[b]{2}{*}{ Fiscal Year } & \multirow[b]{2}{*}{$\begin{array}{l}\text { Woolen } \\
\text { Cloth }\end{array}$} & \multirow[b]{2}{*}{$\begin{array}{c}\text { Artificial } \\
\text { Wool }\end{array}$} & \multirow[b]{2}{*}{ Blankets } & \multirow[b]{2}{*}{ Total } & \multicolumn{2}{|c|}{ For Sale } \\
\hline & & & & & $\begin{array}{l}\text { Used in } \\
\text { Military } \\
\text { Service }\end{array}$ & Others \\
\hline $\begin{array}{l}\text { 1910.. } \\
1911 . . \\
1912 \ldots\end{array}$ & $\begin{array}{c}\text { Yen } \\
2,221,362 \\
2,439,135 \\
2,610,670\end{array}$ & $\begin{array}{c}Y e n \\
3,483 \\
3,105 \\
734\end{array}$ & $\begin{array}{c}Y e n \\
64,750 \\
81,434 \\
123,076\end{array}$ & $\begin{array}{c}\text { Yen } \\
2,289,595 \\
2,523,674 \\
2,734,480\end{array}$ & $\begin{array}{c}\text { Yen } \\
1,888,062 \\
2,082,441 \\
2,249,696\end{array}$ & $\begin{array}{c}Y e n \\
\text { I } 45,540 \\
213,991 \\
\text { I } 68,275\end{array}$ \\
\hline
\end{tabular}

Note: Articles excepting those denoted by "for sale" are not yet sold but stored.

Materials needed for the industry in question are classified according to places of supply as follows:

(I) Kind of Articles. (I) Manufactures. (a) Domestic Products.-Thistle nuts, ammonia, sulphuric acid, leather manufactures (belts, ox-hide belts), manufactures of cotton yarn (spindle bands, spindle cotton), brick, cocoanut, palm oil, cotton belt, hemp manufactures (spun yarn, selvage yarn, hemp, rope), cement, camphor oil, machine oil, refined oil, valve oil, engine oil, coal, machines, machine accessories, timber, warming belts.

(b) Imports from Foreign Countries.-Hemp cloth (broad), mompa (a kind of cotton flannel) (broad), card clothings, oleine oil, leather manufactures (belts, rubbers), olive oil, machines, machine accessories, machine oil. 
(2) Semi-manufactured Articles. (a) Domestic Products.Tops with roll.

(b) Imports from Foreign Countries.-Tops for woolen cloth manufacture, nails for the same object.

(3) Raw Materials. (a) Domestic Products.-Wool, materials for artificial wool (for socks, hand shoes), dyestuffs (acetic acid, indigo ball, acetic ammonia, sulphate of soda).

(b) Imports from Colonies.-Wool, coal.

(c) Imports from Foreign Countries.-Wool, dyestuff.

Clothing Manufacture.-The principal items of clothing, caps, uniforms, summer coats, and trousers, overcoats, puttees and military shoes are to be made in this factory, and the others, many of them being accessories to clothing, are purchased from the manufacturers at large. As the organs for clothing manufacture, the head department of military clothing is located in Tokyo, with branches in Osaka and Hiroshima, which locations were selected in consideration of convenience in the delivery of manufactures to every military division and in the supply of raw materials and workmen. In the following paragraphs is shown an outline of the history of these offices.

In 35 Meiji (I902), the shoemaking factory was set up in Tokyo, and military shoes were made there for the first time; next the cutting factory for cutting materials was established in the same city; and in the next year a branch of the latter factory was established in Osaka.

In 37 Meiji (1904), the head department in Tokyo and the branch in Osaka started the sewing of the principal clothing articles.

In 38 Meiji (1905), in the Osaka branch the shoemaking factory was set up and work started.

In 40 Meiji (1907), a branch was located in Hiroshima, and sewing was started there. After that, the service being gradually enlarged, in 43 Meiji (1910), the shoemaking factory was set up, which resulted in a great expansion of the work. 


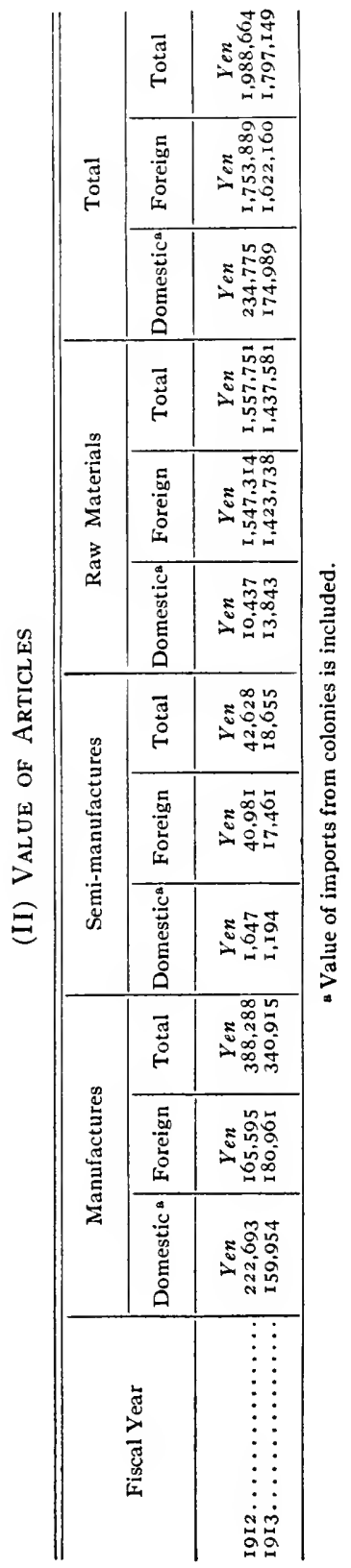




\section{A General View of the Manufacture at Present}

The work of this manufactory is the manufacture, mainly by the use of mechanical power, of clothing (military clothing and shoes) for noncommissioned officers and soldiers. The number of factories, men engaged, and articles made in this manufactory at present are approximately as follows:

NUMBER OF FACTORIES, MEN ENGAGED AND MOTIVE ENGINES

(I) NUMBER OF FACTORIES

\begin{tabular}{|c|c|c|c|c|}
\hline Factories & $\begin{array}{l}\text { Head } \\
\text { Arsenal }\end{array}$ & $\begin{array}{l}\text { Osaka } \\
\text { Branch }\end{array}$ & $\begin{array}{c}\text { Hiroshima } \\
\text { Branch }\end{array}$ & Total \\
\hline $\begin{array}{l}\text { Sewing factories. . . . . . . . . } \ldots \ldots \ldots \ldots \\
\text { Shoemaking factories } \ldots \ldots \ldots \ldots\end{array}$ & $\begin{array}{l}4 \\
2\end{array}$ & $\begin{array}{l}3 \\
\mathbf{I}\end{array}$ & $\begin{array}{l}4 \\
2\end{array}$ & $\begin{array}{r}\text { II } \\
5\end{array}$ \\
\hline Total & 6 & 4 & 6 & I6 \\
\hline
\end{tabular}

(II) NUMBER OF WORKMEN

\begin{tabular}{|c|c|c|c|c|c|c|c|c|}
\hline \multirow{2}{*}{ Factories } & \multicolumn{2}{|c|}{ Head Arsenal } & \multicolumn{2}{|c|}{ Osaka Branch } & \multicolumn{2}{|c|}{$\begin{array}{l}\text { Hiroshima } \\
\text { Branch }\end{array}$} & \multicolumn{2}{|c|}{ Total } \\
\hline & Males & Females & Males & Females & Males & Females & Males & Females \\
\hline $\begin{array}{l}\text { Sewing } \\
\text { Shoemak- } \\
\text { ing fac- } \\
\text { tories ... }\end{array}$ & 133 & 506 & 56 & 377 & $8 \mathrm{I}$ & 409 & 270 & $\begin{array}{r}1,292 \\
46\end{array}$ \\
\hline Total. & 290 & 522 & 159 & 387 & 160 & 429 & 609 & 1,338 \\
\hline
\end{tabular}

(III) Motive Power Engines

(I) Number

\begin{tabular}{r|c|c|c|c|c}
\hline Arsenals & $\begin{array}{c}\text { Steam } \\
\text { Engines }\end{array}$ & Dynamos & $\begin{array}{c}\text { Electro- } \\
\text { motors }\end{array}$ & $\begin{array}{c}\text { Gas } \\
\text { Motors }\end{array}$ & $\begin{array}{c}\text { Petroleum } \\
\text { Motors }\end{array}$ \\
\hline $\begin{array}{r}\text { Head Arse- } \\
\text { nal ..... }\end{array}$ & 2 & 4 & 24 & 3 & 2 \\
$\begin{array}{r}\text { Osaka } \\
\text { Branch... }\end{array}$ & I & 2 & 3 & $\ldots$ & 4 \\
$\begin{array}{r}\text { Hiroshima } \\
\text { Branch... }\end{array}$ & I & I & 9 & $\ldots$ & $\ldots$ \\
& 4 & 7 & 36 & 3 & 6 \\
\hline
\end{tabular}


(III) Motive Power Engines-Contimued

(2) Horse Power

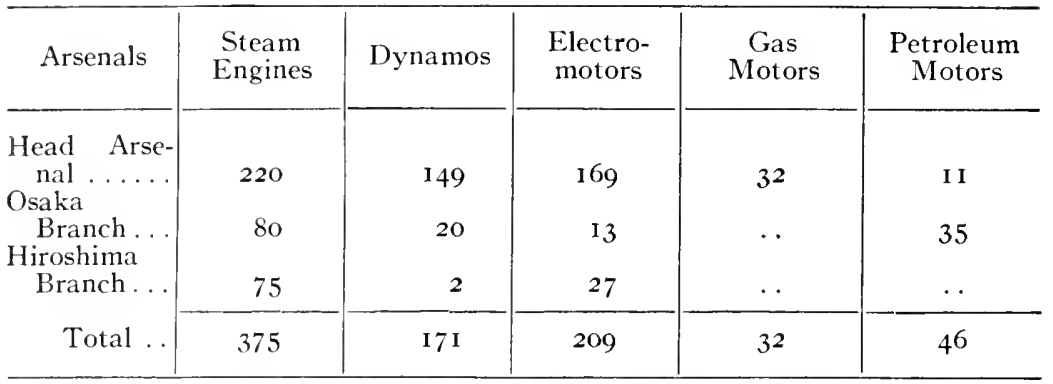

(3) Fuel and Electric Power Consumed During a Fiscal Year

\begin{tabular}{|c|c|c|c|c|}
\hline Arsenals & Coal & Gas & Petroleum & $\begin{array}{c}\text { Electric } \\
\text { Power }\end{array}$ \\
\hline $\begin{array}{l}\text { Head Arsenal. ....... } \\
\text { Osaka Branch...... } \\
\text { Hiroshima Branch... }\end{array}$ & $\begin{array}{l}\text { Tons } \\
885 \\
607 \\
618\end{array}$ & $\begin{array}{c}I, 000 \mathrm{c} . \mathrm{ft} . \\
82 \\
\ldots \\
\ldots\end{array}$ & $\begin{array}{c}\text { Koku } \\
3 \\
20 \\
\ldots\end{array}$ & $\begin{array}{c}K . W . H \\
6,996 \\
\ldots \ldots \\
12,6+7\end{array}$ \\
\hline Total........... & $2, \mathrm{IIO}$ & 82 & 23 & $19,6+3$ \\
\hline
\end{tabular}

The following is a table comparing the expenditures for manufacture during three fiscal years:

\begin{tabular}{|c|c|c|c|}
\hline Articles & 1910 & I9II & 1912 \\
\hline & Yen & Yen & Yen \\
\hline$\ldots \ldots$ & 51,802 & I I I, 372 & I 29,204 \\
\hline Winter coats . . . . . . . . . . . . . & 860,448 & 874,201 & 351,23 \\
\hline Winter trousers. . . . . $\ldots \ldots \ldots \ldots \ldots$ & 678,346 & 874,565 & $666,4^{22}$ \\
\hline Summer coats..................... & I 26,725 & 302,790 & 357,444 \\
\hline Summer trousers $\ldots \ldots \ldots \ldots \ldots \ldots \ldots \ldots$ & I I 7,403 & 292,243 & 266,484 \\
\hline$\cdots \cdots \cdots \cdots \cdots \cdots \cdots \cdots$ & $1,711,052$ & 968,853 & 754,475 \\
\hline$\ldots \ldots \ldots \ldots$ & 165,955 & 147,000 & 211,733 \\
\hline Laced boots. . . . . . . . . . . . . . . . . . . & 588,732 & 670,590 & 547,894 \\
\hline$\ldots \ldots \ldots \ldots \ldots \ldots \ldots \ldots$ & 42,940 & 33,544 & 547,894 \\
\hline$\cdots \ldots \ldots \ldots \ldots \ldots \ldots \ldots$ & 16,109 & 27,898 & I 12,603 \\
\hline & & 3,056 & 4 \\
\hline
\end{tabular}

The principal materials for manufactures according to the places of supply are classified as follows:

(I) Kind of Articles. (I) Manufactures. (a) Domestic Products.-Yellowish-brown cloth, cloth for gaiters, cloth for badges, woolen yarn for hosiery, drillings, leather cotton cloth, cotton flannel, cotton yarn, mompa (a kind of cotton flannel), 
calico, heavy hemp cloth, hemp cloth for padding, hemp cloth for cap lining, hemp cloth for tent, upper shoe leather, sole shoe leather (surface), sole shoe leather (middle), visors, brim leather, jowl pieces, metal ceiling, paddings, zinc eyelets, braids, cotton yarn, upper leather sewing yarn, spikes.

(b) Foreign Products.-Woolen yarn for hosiery, fur, spikes, sole sewing yarn, wooden nails.

(2) Raw Materials. (a) Domestic Products.-Wool grease, leather oil.

(b) Foreign Products.-Wool grease, leather oil, gelatine orange.

(II) Value of Articles

\begin{tabular}{|c|c|c|c|c|c|c|c|}
\hline \multirow{2}{*}{$\begin{array}{l}\text { Fiscal } \\
\text { Year }\end{array}$} & \multicolumn{2}{|c|}{ Materials } & \multicolumn{2}{|c|}{ Raw Materials } & \multicolumn{2}{|c|}{ Total } & \multirow{2}{*}{$\begin{array}{l}\text { Grand } \\
\text { Total }\end{array}$} \\
\hline & Domestic & Foreign & Domestic & Foreign & Domestic & Foreign & \\
\hline & $Y$ & $Y e$ & Ye & Ye & $Y e$ & $Y_{t}$ & $Y$ \\
\hline 1 & 4 & I & & 2,1 & 4,487 & 14 & $4,50 \mathrm{I}, 906$ \\
\hline I & $4,147,128$ & $13,04 \mathrm{I}$ & 32,404 & 4,000 & $4,179,532$ & 17,041 & $4,196,573$ \\
\hline
\end{tabular}

(III) Equipment.-The principal items in military equipment are knapsacks, haversacks, lunch boxes, water bottles and portable tents; of which the knapsacks and the haversacks are made in private factories to which a part of the materials for making is delivered, while the making of the lunch boxes, the water bottles and the portable tents is committed to the arsenal.

Outline of the History of Equipment.--The haversack was patterned in September, 25 Meiji (1892), the knapsack, in July, 37 Meiji (1904) for the first time, and parts improved thereafter.

The knapsack which had been divided into several kinds (for infantry, artillery, engineer, etc.) was made uniform and the color of the thong, etc., was changed to the natural color of the skin, yellowish brown. The material of lunch box and the water bottle was changed to aluminum, in November, $3 \mathrm{I}$ Meiji (1898), heretofore the lunch box being of black lac- 
quered iron plate, and the water bottle being of glass with a cover of black leather.

In January, 38 Meiji (1905), the color of the lunch box and the water bottle was changed to yellowish brown.

The field tent was patterned in March, 36 Meiji (1903), and in October, 39 Meiji (I906), its color was changed to yellowish brown.

Table Comparing Value of Articles Made in Successive Fiscal Years

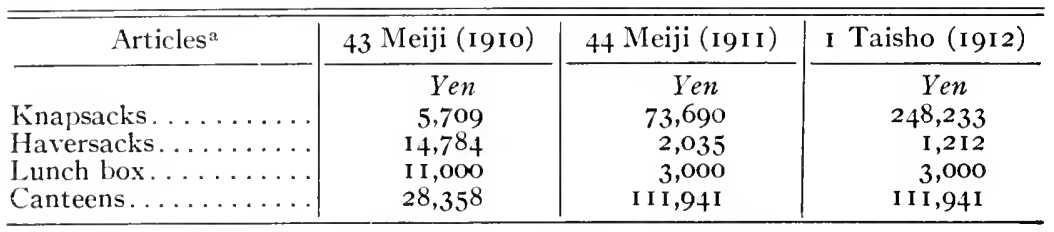

a Field tents were not made during this period.

The expenses of manufacture during the last three fiscal years are as follows:

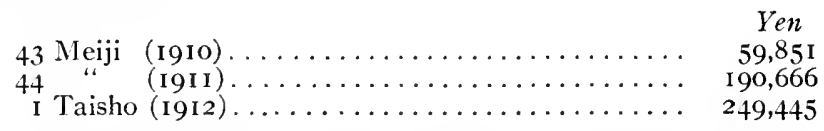

Principal Material for Manufacture According to the Places of Supply

Domestic Products:

Buckles for hemp haversacks, yellowish-brown heavy hemp cloth, hemp cloth for knapsack, buckles and boxes for knapsack, posts and props for portable tents. Foreign Products:

Aluminium, goat skins.

Imports from Colonies:

Fur for knapsack.

The number of the principal articles of equipment bought or manufactured per year are, in round numbers, as follows:

Number

Articles for a Year

Knapsacks......... 20,000

Haversacks........ 33,000

Lunch boxes. . . . . . . 10,000

Canteens............ 9,000

Portable tents......... 17,000 ,

\section{Remarks}

Bought from leather manufacturers.

Made by tailors from material delivered.

Manufacture committed to the Osaka Arsenal.

Manufacture committed to the Tokyo Arsenal. 


\section{Provisions}

The experience gained in the Sino-Japanese War demonstrated the necessity of the manufacture of provisions by the government, and it was after this war that the industry was started. Before the Russo-Japanese War, there was nothing worth mentioning, and so the history from the Sino-Japanese War to the present time is here given as a whole.

In March, 30 Meiji (I897), the Military Central Provision Department was established in Tokyo, with a branch at Ujina, to manufacture, supply, store, supplement and examine the provisions needed for military service.

In January, 3I Meiji (I898), the canning of beef was started.

In December, 36 Meiji (I903), corn cleaning was started at the Ujina branch.

In August, 37 Meiji (1904), the making of soy extract was started.

In September of the same year, a slaughter house was built at the Central Department, and slaughter for the purpose of canning was started.

In March of the same year, the Osaka branch of the Military Provision Department was opened.

In August of the same year, biscuit making was started in the Central Department.

In September, 44 Meiji (I9II), beef canning was started in the Ujina branch.

In January, 2 Taisho (I9I3), biscuit making was started in the Osaka branch.

In February of the same year, pickle making was started in the Central Department.

Articles made in the department, and factories at the present time are as follows:

Articles or Work

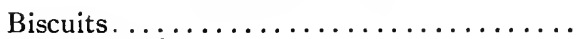

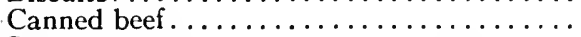

Soy extract.$\ldots \ldots \ldots \ldots \ldots \ldots \ldots \ldots \ldots$

Pickle.........................

Rice and barley cleaning. ............

\section{Number of}

Factories

2

2

I

I

I
Places

Tokyo, Osaka

Tokyo, Hiroshima

Tokyo

Tokyo

Hiroshima 
The amounts of manufacture, rate of increasing manufacturing capacity and expenses of manufacture for several years are compared as follows:

Table Comparing Value of Manufactures, 1908-i912

\begin{tabular}{|c|c|c|c|c|c|c|c|}
\hline Year & Biscuits & $\underset{\text { Beef }}{\text { Canned }}$ & Salt & $\begin{array}{c}\text { Soy } \\
\text { Extract }\end{array}$ & $\begin{array}{c}\text { Fukujin- } \\
\text { zuke }^{a}\end{array}$ & $\begin{array}{l}\text { Cleaned } \\
\text { Rice }\end{array}$ & $\begin{array}{c}\text { Cleaned } \\
\text { Barley }\end{array}$ \\
\hline & Yen & Ye & $Y e$ & Yen & Yen & Ye & Yen \\
\hline $\begin{array}{l}1908 \\
1909\end{array}$ & $\begin{array}{l}268,532 \\
268,136\end{array}$ & $\begin{array}{l}444 \\
456\end{array}$ & $\begin{array}{l}3,6 \\
3,6\end{array}$ & $\begin{array}{l}60, \\
60,\end{array}$ & $\cdot$ & & $\begin{array}{r}199,55 \mathrm{I} \\
90,277\end{array}$ \\
\hline I9IO & 268,0 & 458,9 & 3,6 & 60,4 & & 30 & 81,493 \\
\hline I9 I I & 307, & 236,5 & 20,9 & 34,4 & & 442,1 & 144,606 \\
\hline I9I2 & $35^{2}, \mathrm{I} 37$ & 525,016 & 12,425 & 56,898 & 2,243 & 365,385 & I 54,152 \\
\hline
\end{tabular}

a A kind of pickle.

Rate of Increase in Manufacturing Capacity, 1908-19i2

\begin{tabular}{|c|c|c|c|c|c|c|c|}
\hline Year & Biscuits & $\begin{array}{c}\text { Canned } \\
\text { Beef }\end{array}$ & Salt & $\begin{array}{c}\text { Soy } \\
\text { Extract }\end{array}$ & $\begin{array}{c}\text { Fukujin- } \\
\text { zuke }^{\mathrm{a}}\end{array}$ & $\begin{array}{c}\text { Cleaned } \\
\text { Rice }\end{array}$ & $\begin{array}{c}\text { Cleaned } \\
\text { Barley }\end{array}$ \\
\hline 1908 & IOO & 100 & 100 & IOo & $\ldots$ & 100 & IOO \\
\hline 1909 & 99 & 102 & 100 & 100 & $\ldots$ & 106 & 45 \\
\hline 1910 & 99 & 103 & 100 & 100 & & 83 & 40 \\
\hline I9I I & $I_{4} 4$ & 53 & 569 & 57 & $\ldots$ & $12 \mathrm{I}$ & 72 \\
\hline 1912 & I3I & II 8 & 337 & 94 & 100 & 100 & 77 \\
\hline
\end{tabular}

a A kind of pickle.

Expenses of Manufacture, 1908-I9I2

Year

4I Meiji (1908). . . .

$\ldots \ldots \ldots \ldots \ldots \ldots \ldots \ldots \ldots \ldots$

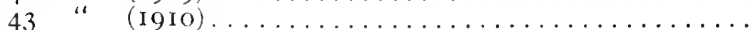

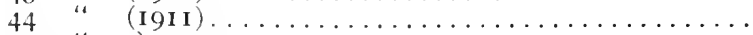

45

I Taisho

\}

I9I 2)
Cost of Manufacture Yen

777,083

788,610

$79 \mathrm{I}, 041$

599,375

948,719

Number of Workmen Engaged in the Provision Industry, i908-igi 2

Year

4I Meiji (I908).

42 " (I909)

43 " $\quad(1910) \ldots \ldots \ldots \ldots \ldots \ldots \ldots$

$44 " \quad($ I9II $) \ldots \ldots \ldots \ldots \ldots \ldots \ldots$

${ }^{45}$ I Taisho $\}($ I9I 2$) \ldots \ldots \ldots \ldots \ldots \ldots$
Males

$3 \mathrm{I}, 727$

$+7,090$

53,428

63,412

68,820
Females

$3 \mathrm{I}, 245$

47,504

49,101

60,103

65,619
Total

62,972

94,594

I02,529

123,515

I 34,439 
Average number per day of the workmen at the present time is 264 males, 202 females, 466 in all.

The work of manufacture is simpler than that of any other industry, and does not need various kinds of materials as in other cases.

Materials needed in this manufacture according to places of supply are shown as follows:

(I) Kind of Articles. (I) Manufactures. (a) Domestic Products.-Solid salt, powdered salt, paper pouches, wooden boxes, ropes, cotton yarn, straw bags.

(b) Imports from Foreign Countries.-Nails.

(2) Semi-manufactures. (a) Domestic Products.--Plates of abies firma (for wooden boxes).

(b) Imports from Foreign Countries.-Iron plates.

(3) Raw Materials. (a) Domestic Products.-Beef, wheat flour, sugar, soy, sweet "sake," rice flour, salt, sesame, potatoes, vegetables for pickling.

(b) Imports from Foreign Countries.-Hops, tin, lead, Indian rubber, varnish for painting, shellac for painting, ammonia.

(II) Value of Articles

\begin{tabular}{|c|c|c|c|c|c|c|c|c|c|}
\hline \multirow{2}{*}{$\begin{array}{l}\text { Year } \\
\text { (fiscal) }\end{array}$} & \multicolumn{2}{|c|}{ Manufactures } & \multicolumn{2}{|c|}{$\begin{array}{c}\text { Semi- } \\
\text { manufactures }\end{array}$} & \multicolumn{2}{|c|}{ Raw Materials } & \multicolumn{2}{|c|}{ Total } & \multirow{2}{*}{$\begin{array}{l}\text { Grand } \\
\text { Total }\end{array}$} \\
\hline & Domestic & Foreign & Domestic & Foreign & Domestic & Foreign & Domestic & Foreign & \\
\hline $\begin{array}{l}\text { I9I2 } \ldots \\
\text { I913 . }\end{array}$ & $\begin{array}{c}\text { Yen } \\
103,635 \\
\text { I } 33,418\end{array}$ & $\begin{array}{l}\text { Yen } \\
229 \\
599\end{array}$ & $\begin{array}{c}Y e n \\
2,515 \\
24,021\end{array}$ & $\mid \begin{array}{c}\text { Yen } \\
\text { I O9,884 } \\
\text { I I I } 358\end{array}$ & $\begin{array}{c}\text { Yen } \\
756,205 \\
861,576\end{array}$ & $\begin{array}{c}\text { Yen } \\
13,231 \\
16,922\end{array}$ & $\begin{array}{c}\text { Yen } \\
862,355 \\
\text { I,019,015 }\end{array}$ & $\begin{array}{c}\text { Yen } \\
\text { I } 23,344 \\
\text { I } 28,879\end{array}$ & $\begin{array}{c}\text { Yen } \\
985,699 \\
\mathbf{1}, \mathbf{1} 47,894\end{array}$ \\
\hline
\end{tabular}

\section{Supplement}

A general view of the military industry has been given above and in conclusion tables are given below explaining the military industrial engines and the number of employes in military factories. 


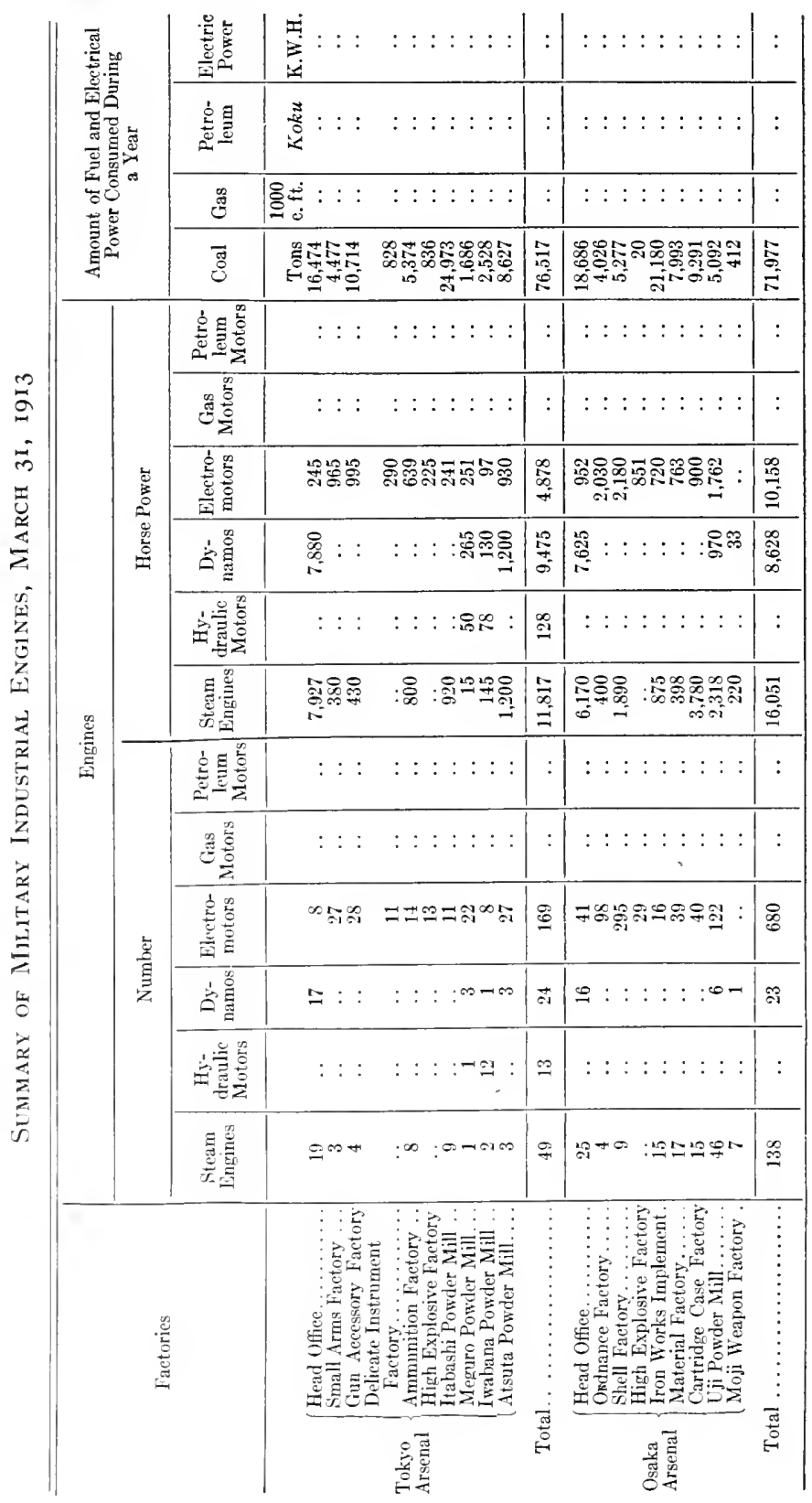




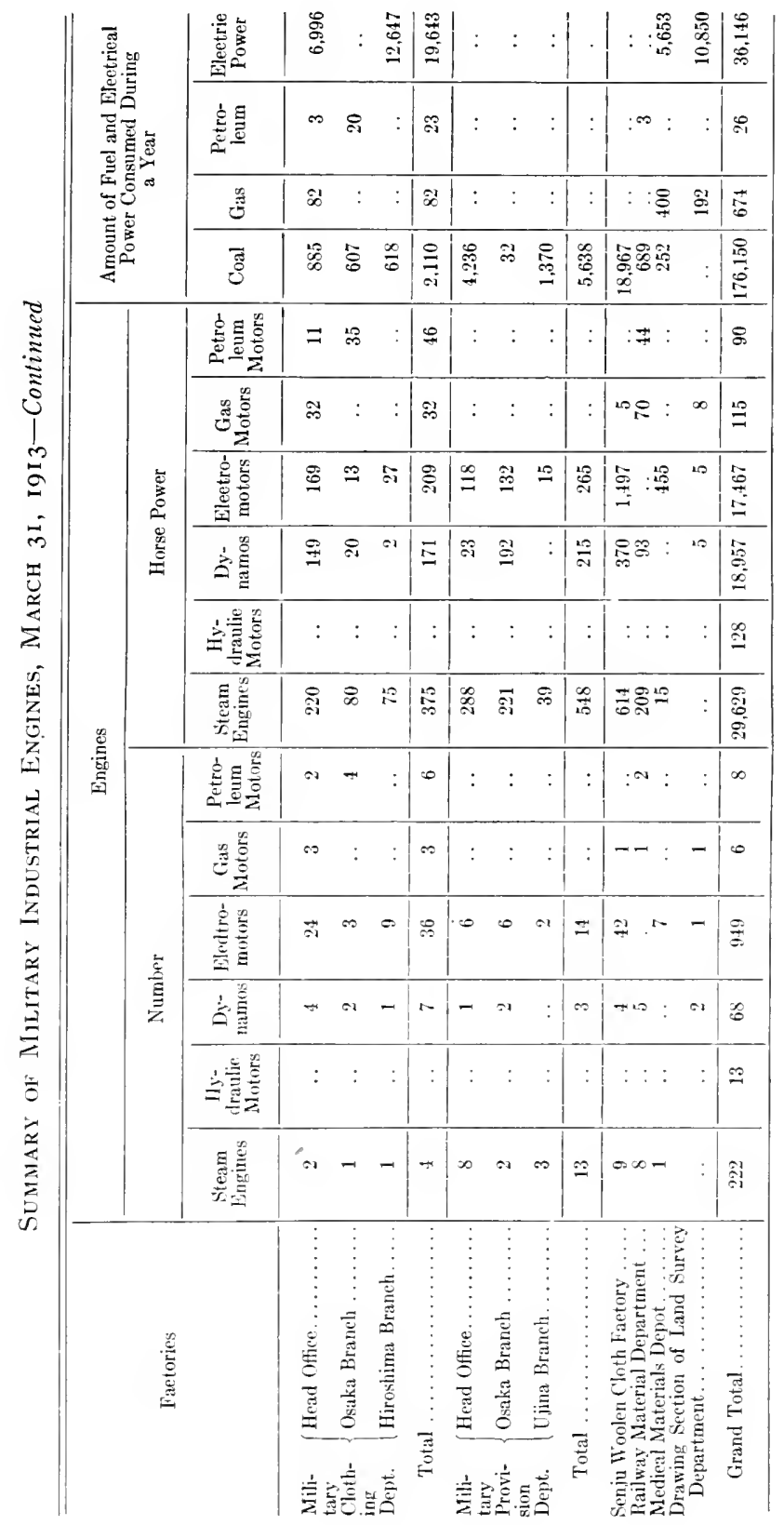




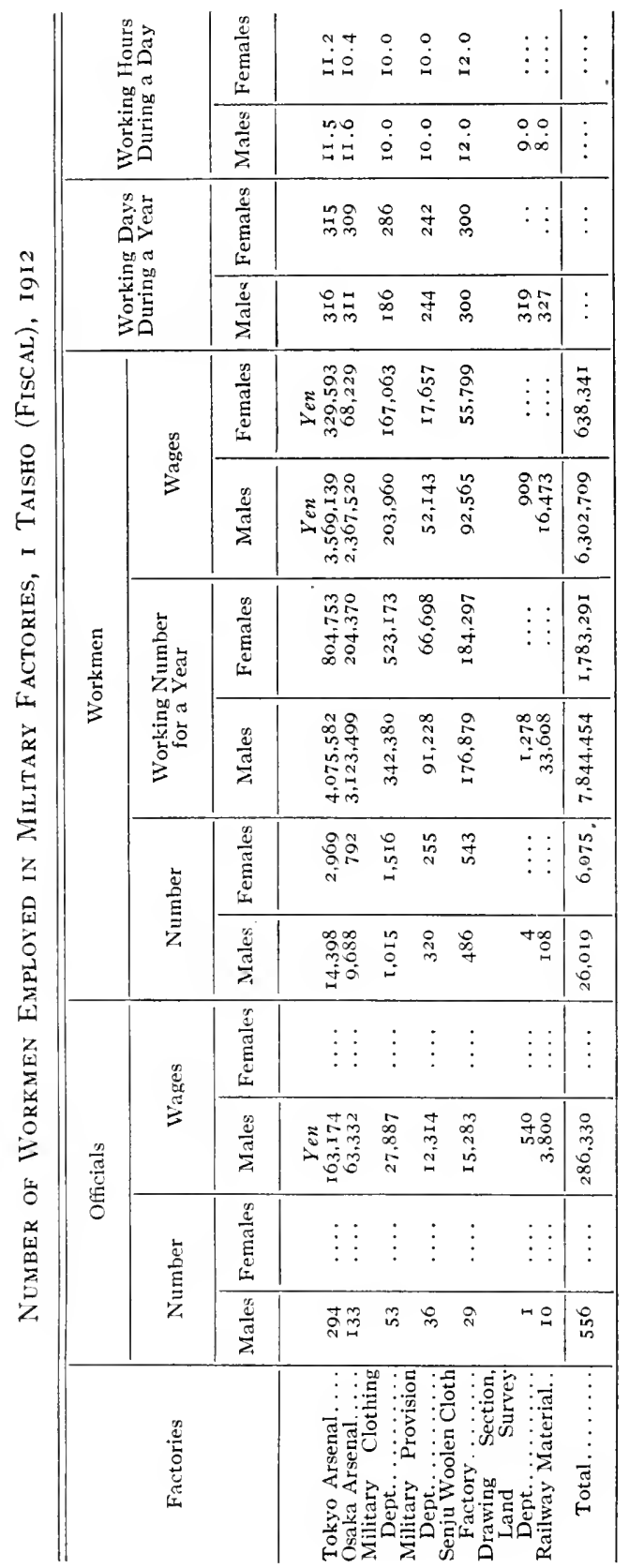




\section{INDUSTRIES OF THE NAVY}

Because of the fact that all the European countries were keeping strict neutrality during the Russo-Japanese War, the two warships, the Katori and the Kashima, which were almost completed in England, could not be sent round to Japan, and under such circumstances it was of course impossible to import fresh war vessels from foreign countries. Meanwhile, Japan lost ten warships and torpedo-boat destroyers in the war and was deprived of much of her naval power. Prompted by the need of making up these losses and also to make a new increase of her power, she then began to build warships with her own materials at her own government and private shipbuilding yards.

In Japan, even before this time, the construction of a firstclass battleship was never an impossibility as far as equipment and skill are concerned. On account of lack of materials and other reasons, however, it was absolutely impossible to do it at the same cost as if built in England; and moreover in rapidity of work, Japan could not but be unequal to such countries as England, France, Germany or America; hence there was a tendency to order warships from foreign builders. But as, under the circumstances, there was no time to consider any such difficulties, necessary arrangements were made to construct first-class battleships and cruisers at the Yokosuka and Kure arsenals, and cruisers, dispatch boats, or torpedo-boat destroyers at the Sasebo and Maizuru arsenals and several other large private dockyards, and the work started at once.

This may be called the third extension of the Japanese Navy, and for this purpose a large amount of naval expenditure was incurred, but thanks to the zeal of all classes of the people, the task was at last finished, and the long-sought-for ambition of procuring war implements independently of foreign countries was realized. It ought to be said with exactness that the 38 th year of Meiji made a new epoch in warship building in the Empire of Japan. The new plan was to build two first-class battleships and four first-class battle cruisers, one second-class cruiser, two dispatch boats, and 
thirty-three torpedo-boat destroyers, making a total of fortytwo ships; and the estimated cost for the above was $212,26 \mathrm{I}$,055 yen. These vessels were all completed soon after the war between Japan and Russia was over. From the experiences of actual warfare gained in the war, considerable improvement was made in the building of these vessels. The principal improvements were to increase the displacement as much as possible, to increase the number of the ordnance and the calibre of the same, and the thickness and size of the armor plates, all in proportion to the increase of the displacement, to increase the power of the fish torpedo according to the increase of displacement, at the same time decrease it in inverse proportion to the increased power of the ordnance, to increase the speed as much as possible, to dispense with the ram, to perfect the means of protection against the mechanical mine, to construct a powder magazine free from explosion by meteorological changes, and in the case of ships built capable of being fitted up as auxiliary cruisers, to place important parts of the steering system under the waterline, and to provide the same with necessary protective devices, etc.

After the Russo-Japanese War, this plan of shipbuilding was carried out in one ship after another, and all were finished with success, especially, in the case of the first-class battleships and armored cruisers, both of which, the former of about 20,ooo tons and the latter of about I 4,000 tons, were of such great size that there were hardly any to compare with them in the world, and still they showed unexpectedly good results. It may be remarked that this was a very rapid advance, a matter truly worthy of congratulations to the shipbuilding industry of Japan. Since the completion of these warships, the navy, seeing the necessity of further enlargement in due accordance with the extension of the power of the country, has continued to build new large ships, and already launched battleships of 30,000 tons. The estimated expenditure for building these new vessels, so far approved by the Imperial Diet, has amounted to $84,644,124$ yen.

Following is a summary of the development of the naval industry in this period: 


\section{Warships and Torpedo-boat Destroyers}

(I) Warships.-In February, 37 Meiji (I904), the thirdclass cruiser Tsushima was completed at the Kure Naval Arsenal. Keel laid October, 34 Meiji (I90I); displacement, 3,366 tons; horse power, 9,400; speed, 20 knots; equipped with $66^{\prime \prime}$ quick-firing main guns, Io I2 pounder quick-firing side guns, $447 \mathrm{~mm}$. auxiliary guns; 3 searchlights, but with no torpedo tube, like the sister ship Niitaka.

In September, 37 Meiji (I904), the third-class cruiser Otowa was completed at the Yokosuka Naval Arsenal. Keel laid January, 36 Meiji (I903); displacement, 3,000 tons; horse power, I0,000; speed, 2 I knots. Main guns, 2 6" quickfiring guns; side guns, $64.7^{\prime \prime}$ quick-firing guns; auxiliary, 4 quick-firing 12 pounders and 2 Maxim guns; 3 searchlights. This ship was 336 tons less in displacement compared with the Niitaka or the Tsushima. In arms and protective deck she was also somewhat lighter than those two ships, but the weight so saved was added to the engines to increase her horse power, which raised her speed to 2 I knots. Like her sister ships she was built without a torpedo tube. She had in some respects a slight resemblance to a despatch boat, though built for a protected cruiser. It took only twenty months to build this ship, the quickest record ever made in this country. Of course, being in war-time, it owed much to the industrious efforts of all of those engaged in the work, from the overseeing officers to the workmen, but at the same time it is enough to show what a rapid development was being made in the shipbuilding industry of Japan.

In January, 40 Meiji (I907), the armored cruiser Tsukuba was completed at the Kure Naval Arsenal. Keel laid January, 38 Meiji (I905); displacement, I3,750; horse power, 23,260; speed, 2 I.5 knots. Guns carried: 4 I 2 " quick-firing main guns; I2 $6^{\prime \prime}$ and $34.7^{\prime \prime}$ side guns; 2 quick-firing I2 pounders, and 4 Maxim guns as auxiliaries. The ship has also $3 \mathrm{I} 8^{\prime \prime}$ torpedo tubes and 3 searchlights. The engine is of the twin-screw, surface-condensing, four-cylinder, triple-expansion type, and has a forced lubricating arrangement. This 
ship was intended to be a sister ship to the armored cruiser Ikoma, and was not only the first armored cruiser built in Japan, but was also the first ship for which an engine of 20,000 horse power was ever made in this country.

It was about forty-five years since warship building had commenced in Japan, and in this time more than thirty ships were built; but then the largest ship ever built was the $H a$ shidate of 4,200 tons, and no armored battleship or large-size cruiser had yet been built. Now the Tsukuba, a large-size armored warship, was completed in but two years after her keel laying; and, except England, no country in Europe or America, who was Japan's elder in these matters, had ever before completed such a large ship in such a short time. It is a fact that the construction of the ship took place during the war, and the work had to be pushed for early completion; but, still, to have built such a big ship without experience, and her trial made with every success, shows well enough the wonderful development in the shipbuilding industry of the Empire.

In March, 40 Meiji (1907), the armored cruiser Ikoma was completed at the Kure Naval Arsenal. Keel laid in March, 38 Meiji (I905); displacement, I3,750 tons; horse power, 20,500; speed, 21.75 knots; engines and boilers, the same as the Tsukuba; guns about the same, the only difference being that while the Tsukuba has 2 quick-firing I2 pounders among her auxiliary guns the Ikoma has $23^{\prime \prime}$ guns.

Heretofore it was customary to construct warships with ram heads, which could be used as weapon in time of battle, but of late, owing to the improvement in guns, it became almost useless, and moreover, in practice it was proved to have no advantage whatever, and was only apt to injure a friendly ship.

Therefore, in building the Tsukuba and the Ikoma, for the first time the ram head was done away with, and the bow was made like that of an ordinary sailing ship. The example was followed for all subsequent Japanese warships.

The protective deck of the above two ships is $I^{\frac{1}{2}}{ }^{\prime \prime}$ thick at 
the flat central parts, and $2^{\prime \prime}$ at the sloping sides, which is diminished to $I^{\frac{1}{2}}{ }^{\prime \prime}$ at the two ends, fore and aft; the waterline armor belt is $7^{\prime \prime}$ at the center and $4^{\prime \prime}$ at the fore and aft ends; so the method of the protection is absolute.

As a rule an armored cruiser aims at high speed, and its fighting capacity is therefore far inferior to that of a battleship. It is the same the world over, and usually the main guns carried by such a ship are $8^{\prime \prime}$ to $\mathrm{IO}^{\prime \prime}$, but the above two ships took $12^{\prime \prime}$ guns as their main guns and were besides equipped with many $6^{\prime \prime}$ guns as auxiliaries, so that their fighting capacity was quite equal to that of battleships of $\mathrm{I}_{5}, 000$ to I6,000 tons.

In March, 43 Meiji (I9Io), the first-class battleship Satsuma was completed at the Yokosuka Naval Arsenal. Keel for the same was laid in May, 38 Meiji (I905); displacement, I 9, I 50 tons; horse power, I7,500; speed, I8.25 knots. Main guns are $412^{\prime \prime}$ and $1210^{\prime \prime}$, and side guns $124.7^{\prime \prime}$. She has 5 torpedo tubes. The engines are vertical, four-cylinder, triple-expansion, and the boilers are of the Miyabara water tube system.

Compared to the well-known British warship Dreadnought, the Satsuma was far behind in speed, but in size she was larger by 1,200 tons, and had therefore the honor of being the largest warship in the world. That such a large ship was launched in but one year and seven months, at a dockyard where they had never had experience in a big work like this, was another remarkable instance of the advance made in warship building in Japan.

In March, 43 Meiji (I9Io), the first-class battleship $A k i$ was completed at the Kure Naval Arsenal. Laid down in March, 39 Meiji (I906); displacement, I9,800 tons; horse power, 25,000; speed, $20 \frac{1}{2}$ knots. Guns carried: 4 I $2^{\prime \prime}$ main guns, I $2 \mathrm{IO}^{\prime \prime}$ side guns, $86^{\prime \prime}, 83^{\prime \prime}, 43^{\prime \prime}$ short guns, as auxiliary guns; 5 I $8^{\prime \prime}$ torpedo tubes.

Owing to her construction having begun later than that of the Satsuma, some improvements were made in this ship after the latest example of the advanced shipbuilding of other coun- 
tries. The principal of these are the adoption of the turbine of the Curtis patent, and increase in horse power, speed, guns, etc. This having added to the weight of the ship naturally increased the displacement, making it 600 tons more than the Satsuma.

The $A k i$ was even more powerful than the Satsuma. At the time of the beginning of construction she was looked upon as one of the largest ships in the world, and at that, she was launched in only one year from her keel laying and therefore broke the record that had been made by the Satsuma some time back. This owed much to the perfect and efficient shipbuilding organization, but experience also had a great deal to do with it.

In November, 42 Meiji (I909), the armored cruiser Kurama was completed at the Yokosuka Naval Arsenal. The ship was laid down in August, 38 Meiji (1905); displacement, I4,500 tons; horse power, 22,500; speed, 20 knots. Main guns, 4 I 2 " quick-firing; side guns, $88^{\prime \prime}$ quick-firing; auxiliary guns, I $44.7^{\prime \prime}$ quick-firing; she also has 3 I $8^{\prime \prime}$ torpedo tubes. This vessel was built as a sister ship to the Ibuki.

In November, 42 Meiji (I909), the armored cruiser Ibuki was completed at the Kure Naval Arsenal. Keel laid May, 40 Meiji (I907); displacement, I 4,636 tons; horse power, 24,ooo; speed, 2 I knots; main guns, 4 I $2^{\prime \prime}$ quick-firing; side guns, $88^{\prime \prime}$ quick-firing; I $44.7^{\prime \prime}$ quick-firing auxiliary guns and $43^{\prime \prime}$ short guns; 3 I 8 " torpedo tubes.

These two sister ships were a great improvement over the Tsukuba or the Ikoma, but, if compared to the Mikasa or the Shikishima, their protective quality is somewhat lower, but their speed and offensive quality are much superior.

The Kurama was launched in twelve months after her keel laying, and the Ibuki in only six months. This is due to nothing but the full and free use of the shipbuilding cranes, and the experience gained from the construction of the Tsukuba and the Ikoma, a fact that may be remarked as having broken the world's record in that industry.

In May, 43 Meiji (I9Io), the second-class protected 
cruiser Tone was completed at Sasebo Naval Arsenal. Her keel was laid in January, 38 Meiji (1905). The design was to build her of the Yoshino type, with some improvements added thereto. Displacement, I4, IOo tons; horse power, I 5,000; speed, 23 knots. The engines are of a twin screw, surface condenser, vertical, four cylinder and triple expansion system; I6 Miyabara boilers used. Main guns, $46^{\prime \prime}$ quick-firing; side guns, I2 $4.7^{\prime \prime}$ quick-firing; auxiliary guns, 2 quick-firing I 2 pounders; 3 I $8^{\prime \prime}$ torpedo tubes. This is the very first warship built at the Sasebo Dockyard. The difference in this ship from the Yoshino is an increase of speed and the reduction of two $6^{\prime \prime}$ guns. Since the building of the warship Niitaka, torpedo tubes had been done away with in protected cruisers, but in the Tone their use was revived, and she was equipped with three.

In July, 4I Meiji (I908), the dispatch boat Yodo was completed at the Kawasaki Dockyard. Keel laid October, 39 Meiji (I906); displacement, I,250 tons; horse power, 6,500; speed, 22 knots. Engine and boiler, same as the Tone. Main guns, $44.7^{\prime \prime}$ quick-firing; side guns, 4 quick-firing 12 pounders; $2 \mathrm{I} 8^{\prime \prime}$ torpedo tubes. This ship is single masted and looks like a large size torpedo-boat destroyer. Being intended for a dispatch boat, she was built with more consideration for her speed than for her arms.

In September, 4I Meiji (1908), the despatch boat Mogami was completed at the Mitsubishi Dockyard. Keel laid March, 35 Meiji (I902); displacement, I,350 tons; horse power, 8,000; speed, 23 knots. Guns carried: $24.7^{\prime \prime}$ quick-firing main guns; $43^{\prime \prime}$ side guns; $218^{\prime \prime}$ torpedo tubes. This dispatch boat may be spoken of as a sister ship of the Yodo, but she is a foot wider, 120 tons more in displacement, I,500 tons more in actual horse power, and a knot more in speed, than the Yodo. The greatest difference between the two is in their engines. While ordinary engines are used in the Yodo, Parson's turbine was adopted for the Mogami, which is the first warship in the Japanese Navy furnished with the new engine.

In November, 44 Meiji (I9II), the gunboat Toba was built 
at the Sasebo Naval Arsenal. Laid down July, 44 Meiji; displacement, 250 tons; horse power, I,400; engine, triplescrew, vertical, and double-expansion; boiler, Miyabara's system.

In March, 45 Meiji (I9I2), the battleship.Kawachi was completed at the Yokosuka Naval Arsenal. Laid down April, 42 Meiji (I909); displacement, 20,800 tons; horse power, 25,000; engine adopted, twin screw Curtis's turbine; boiler, Miyabara type, 16 in number.

In July, 45 Meiji (I9I2), the battleship Settsu was completed at the Kure Naval Arsenal. Keel laid January, 42 Meiji (I909); displacement, 2I,295 tons; horse power, 25,000; engine adopted, twin-screw Curtis's turbine; boiler, Miyabara's system, same number as the Kawachi.

In April, 45 Meiji (I9I2), the second-class cruiser Chikuma was completed at the Sasebo Naval Arsenal. Keel laid May, 43. Meiji (I9I0); displacement, 4,950 tons; horse power, 22,500; engine, Curtis's turbine type; boiler, navy system.

In June, 45 Meiji (I9I2), the cruiser Hirado was completed at the Kawasaki Dockyard. Keel laid in August, 43 Meiji (1910); displacement, 5,200 tons; horse power, 22,500; engine adopted, Curtis's turbine; boiler, navy system, newly adopted instead of Miyabara's, which had been in exclusive use for some time, $\mathrm{I} 6$ in number.

In July, 45 Meiji (I9I2), the cruiser Yahagi was completed at the Mitsubishi Dockyard. Keel laid in June, 43 Meiji (I9I0); displacement, 4,950 tons; horse power, 22,500; engine, Curtis's turbine type; boiler, navy system.

In November, I Taisho (I9I2), the gunboat Saga was built at the Sasebo Naval Arsenal. Her keel was laid in January, 45 Meiji (1912); displacement, 785 tons; horse power, I,600; engine, twin-screw, vertical, triple-expansion; boiler, navy system.

The armored cruiser Hiyei is now under equipment at the Yokosuka Naval Arsenal. Laid down in November, 44 Meiji (I9II). Launched November, I Taisho (I9I2). She has a displacement of 27,500 tons, and 64,000 horse power; engines used are of Parson's turbine system, which has never been used 
before except for the Mogami; boilers, of the navy system. Both in displacement and armament she is the largest ship ever built, and when completed will be the leading power of the armored cruisers in the Japanese Navy. The result with which the work on this ship may be finished, therefore, will be the touchstone of development in the warship building of Japan.

The armored cruiser Haruna is under equipment at the Kawasaki Dockyard. Keel laid in March, 45 Meiji (I9I2). Launched in December, 2 Taisho (1913). Her displacement is to be 27,500 tons ; horse power, 64,000 ; engines to be of Curtis's turbine, and boilers of Miyabara type. This cruiser is expected to be completed by April, 4 Taisho (I9I 5).

The armored cruiser Kirishima is now under equipment at the Mitsubishi Dockyard. Keel laid in March, 45 Meiji (I9I2). Launched in November, 2 Taisho (I9I3). Displacement to be 27,500 tons, and horse power, 64,000 ; engines to be Parson's turbine, and boilers of navy system. This cruiser is a sister ship to the Iaruna, and is expected to be completed by April, 4 Taisho (I9I5).

The battleship Fuso is under equipment at the Kure Naval Arsenal. Keel laid March, 45 Meiji (1912). Launching March, 3 Taisho (19I4). Her displacement is to be 30,600 tons, and horse power 40,000. The engines are to be of quadruplescrew Curtis's turbine, and the boilers of Miyabara type.

The above three ships are at present under equipment, and therefore of their guns and other equipments no definite mention is as yet possible, but in their displacement and horse power, they are the largest ships ever attempted since the beginning of the Japanese Navy, and considering the fact that such giants of battleships have been launched with success, it is quite evident that an extraordinary development has been made in the industry of warship building in Japan both in the government and the private dockyards.

Besides the ships already mentioned, it has been planned to build battleship "No. 4" at the Yokosuka Naval Arsenal, "No. 5" at the Kawasaki Dockyard, and "No. 6" at the Mitsubishi Dockyard; and they are expected to be laid down very 
soon. According to their designs, these ships are to displace 30,800 tons; engines for "No. 4" and "No. 5 " to be of Curtis's turbine, and those for "No. 6," Parson's turbine; and boilers for "No.4" to be of Miyabara type, and for "No.5" and "No. 6," the Yarrow type.

(II) Torpedo-boat Destroyers. - The torpedo-boat destroyers built in this period are 39 in number, from the thirdclass torpedo-boat destroyer Fubuki, completed in February, 38 Meiji (I905), at the Kure Naval Arsenal, to the second-class destroyer Tachibana, completed in June, 45 Meiji (I9I2), at the Maizuru Naval Arsenal. The building of these torpedo-boat destroyers will be presented here only in a brief manner; as for the chronological particulars, they will be found in the table appearing on subsequent pages.

Generally speaking, these torpedo-boat destroyers were built in five periods, from the second construction to the sixth, but we do not call the first of the five periods or constructions the first, but serially call it the "second," as there was already a first lot of torpedo-boat destroyers built before this in 36 Meiji (1903).

The torpedo-boat destroyers built in the second construction are the Ariake, the Fubuki and the Arare; both their keel laying and completion took place during the Russo-Japanese War, 37 Meiji (1904). All of them were built at the Kure Naval Arsenal and are third-class torpedo-boat destroyers of 370 tons. The time spent in their construction varied from five months to eight. They were built after the manner of the Harusame, and all showed excellent results in their trials.

At the outbreak of the Russo-Japanese Var in the 37 th year of Meiji (1904) a plan was decided upon in which twentyfive torpedo-boat destroyers, the third-class destroyer Kamikaze and others, were to be built; and the work having been apportioned among the Yokosuka, Kure, Sasebo, and Maizuru Arsenals, and three private dockyards, it was forthwith started. The engines of these destroyers are, like those of the destroyers built in the second construction, of the same kind as used in ships of the Harusame class, but in some particulars they are differently made, i.e., instead of the oil filter of the forced sys- 
tem, one that can be worked by gravity was used; the main feed pipe in the boiler room was removed to the engine room; the number of fire engines increased; bilge pumps furnished independently, the number of blowers increased, etc. The armament was also altered in these ships by placing short 12 pounders instead of $57 \mathrm{~m} . \mathrm{m}$. quick-firing guns with which ships of the Harusame class are equipped. The boilers too are of the navy system, like those of the Harusame, but the height of the same was lessened, so that they will not project above the deck and will thus be protected from discovery by the enemy's searchlight thrown upon the jutting.

The building of these twenty-five destroyers were distributed as follows:

The Kamikaze, Hatsushimo, Yayoi, Kisaragi, Hibiki, Wak$a b a$ and IIatsuyuki (7 boats) to Yokosuka Arsenal.

The Ushio and Nenohi ( 2 boats) to Kure Arsenal.

The Yugure, Yudachi, Mikazuki and Nowaki (4 boats) to Sasebo Arsenal.

The Oikaze and Yunagi (2 boats) to Maizuru Arsenal.

The Shiratsuyu, Shirayuki, Matsukaze and Shirotae (4 boats) to Mitsubishi Dockyard.

The Asakaze, Harukaze, Shigure and Hatsuharu (4 boats) to Kawasaki Dockyard.

The Asatsuyu and Hayate ( 2 boats) to Osaka Iron Works.

Owing to the war the building of these destroyers was finished with expedition. It was not quite two years since any torpedo-boat destroyers had been built in Japan, and the experience in the work being therefore limited, great difficulties were encountered in the present work, but nevertheless most of the boats were completed in about one year from the keel laying, and all of them gave quite satisfactory results in their trials. An exceptional success was the Ushio, which was built at the Kure Naval Arsenal; her keel was laid on the I2th of April, 38 Meiji (I905), and she was completed on the I 5 th of July of the same year, three months later. The private dockyard, the Osaka Iron Works, took about twenty months to complete its order, but considering the fact that it had no experience in the work, it may be said that the time 
made by it was rather a success. The time at which all of these ships were completed varies from July, 38 Meiji (I905), to March,40 Meiji (1907). At all events, the building of these torpedo-boat destroyers would well deserve special mention as an advance made in the warship building of Japan.

The destroyers Shigure and Asatsuyu showed a speed of over 29.7 knots, the best shown of all the torpedo-boat destroyers.

The following are the results of the official trial of the destroyer Shigure: Displacement, 376.5 tons; boiler pressure, 2 I 6 pounds; engine pressure, 203 pounds; revolution, 390; horse power, 6,4I6; speed, 29.73 knots.

In May, 38 Meiji (I905), while the war with Russia was going on, the fourth construction of torpedo-boat destroyers was decided upon, and orders were given to private companies, to build four destroyers, as follows:

The Uzuki, to the Kawasaki Dockyard.

The Minazuki, to the Mitsubishi Dockyard.

The Nagatsuki and Kikuzuki, to the Uraga Dock Company.

Although the engines of these four ships were on the whole the same as those of the ships made in the third construction, some further improvements were made. For instance, the main feed pipes which had been removed to the engine room (from the boiler room) in the case of the twenty-five ships already mentioned were in this case again placed in the boiler room as in ships of the Irarusame class; also the double bar hollow link hitherto used for the apparatus for starting the engine was changed to a double bar solid link, as in practice it was found that the former was inconvenient for regulation and not in good working order.

As to the boilers, they were fitted up with water tubes of the navy system, and compared with those of the ships of the Harusame class, were somewhat improved, like those of the ships made in the third construction.

All of the four ships gave satisfactory results in their official trials; especially in the cases of the Uzuki and the Minatsuki the speed reached above 29.8 knots. They were completed between October, 39 Meiji (I906) and September, 40 Meiji (1907). 
In December, 39 Meiji (I906), three ships named Uranami, Isonami and Ayanami were decided upon to be built as the fifth construction of torpedo-boat destroyers of domestic building at the Maizuru Naval Arsenal, and work was begun in 40 Meiji (I907). The construction, arms, engines and boilers of these three ships had many novel features of improvement learned from the experience of actual warfare in the RussoJapanese War. The ships were launched in 40 Meiji (1907), 4I Meiji (I908) and 42 Meiji (I909).

The sixth construction of torpedo-boat destroyers at the domestic yards was carried on from 42 Meiji (I909) to 45 Meiji (I9I2).

The Umikaze, a first-class torpedo-boat destroyer of I,224 tons displacement and 20,500 horse power was completed in September, 44 Meiji (I9II), at the Maizuru Naval Arsenal. Her keel was laid in November, 42 Meiji (I909).

The Yamakaze, a first-class torpedo-boat destroyer, was completed in October, 44 Meiji (I9II), at the Mitsubishi Dockyard. She has a displacement of I, I 50 tons, and 20,500 horse power, and was, like the Umikaze, one of the largest destroyers ever made in Japan.

The Sakura, a second-class destroyer was completed in May, 45 Meiji (I9I2), at the Maizuru Naval Arsenal. She was laid down in March, 44 Meiji (I9II), and has a displacement of 678 tons and 9,500 horse power.

The Tachibana, a second-class destroyer, was completed in June, 45 Meiji (I9I2), at the Maizuru Naval Arsenal. Her keel was laid down in April, 44 Meiji (I9II). Displacement, 680 tons; horse power, 9,500.

These four destroyers were the largest of the kind ever built in Japan. They had displacement and horse power two or three times as big as those built before them, and were furnished with up-to-date arms, engines and boilers. They gave unexpectedly satisfactory results in their official trial; especially in their speed a general advancement was manifest.

Although warship building in Japan had made phenomenal progress after the Russo-Japanese War, the building of such large destroyers as these was unknown in this country before 
this time; and it is worth commending as another striking advancement achieved in naval construction in Japan, that the navy, finding from its latest experience the necessity of preparing itself with large destroyers as well as with large battleships, built at a leap, and with good success, destroyers well above a thousand tons.

(III) Supplement.-The following is a chronological table of warships and torpedo-boat destroyers built at domestic dockyards in this period:

Chronological Table of Construction of Warships and Torpedo-boat DESTROYERS

(From the Russo-Japanese War to the Present Time)

\begin{tabular}{|c|c|c|c|c|c|}
\hline Name & Kind and Class & Where Built & Construction a & $\begin{array}{c}\text { Displace- } \\
\text { ment } \\
\text { (Tons) }\end{array}$ & $\begin{array}{l}\text { Date of } \\
\text { Completion }\end{array}$ \\
\hline 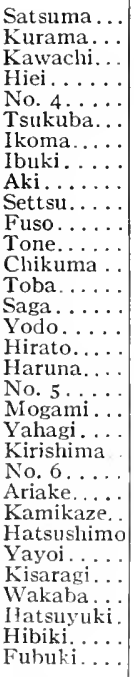 & $\begin{array}{l}\text { Battleship } \\
\text { Battle cruiser } \\
\text { Battleship } \\
\text { Battle cruiser } \\
\text { Battleship } \\
\text { Battle cruiser } \\
\text { ". } \\
\text { Battleship } \\
\text { ". } \\
\text { 2d class cruiser } \\
\text { Gunboat } \\
\text { ". } \\
\text { Dispatch boat } \\
\text { 2d class cruiser } \\
\text { Battle cruiser } \\
\text { Battleship } \\
\text { Dispatch boat } \\
\text { 2d class cruiser } \\
\text { Battle cruiser } \\
\text { Battleship } \\
\text { 3d class destroyer } \\
\text {.. } \\
\text { ". } \\
\text { ". } \\
\text { ". } \\
\text { ". }\end{array}$ & 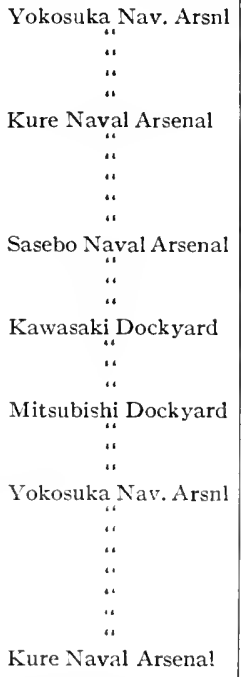 & 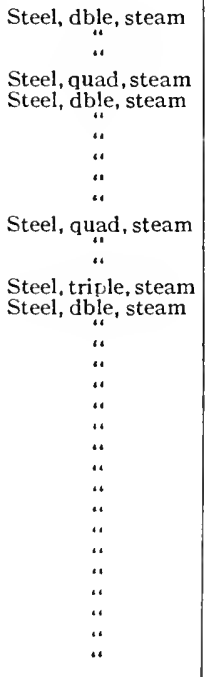 & $\begin{array}{r}19,150 \\
14,600 \\
20,800 \\
27,000 \\
30,800 \\
13.750 \\
13.750 \\
14,600 \\
19,800 \\
21,295 \\
30,600 \\
4,100 \\
4,950 \\
250 \\
785 \\
1,250 \\
4,950 \\
27.500 \\
30,800 \\
1,350 \\
4.950 \\
27.500 \\
30,800 \\
375 \\
375 \\
375 \\
375 \\
375 \\
375 \\
375 \\
375 \\
375\end{array}$ & 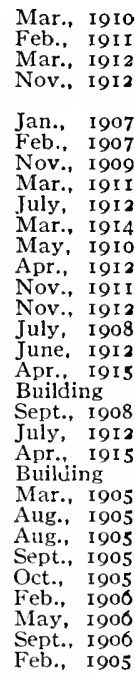 \\
\hline
\end{tabular}

a "Steel" denotes material used for the ship's hull; "double," "triple" and "quad" refer to the number of propellers; "steam," steam power. 
Chronological Table of Construction of Warships and Torpedo-boat DEstroyers-Continued

(From the Russo-Japanese War to the Present Time)

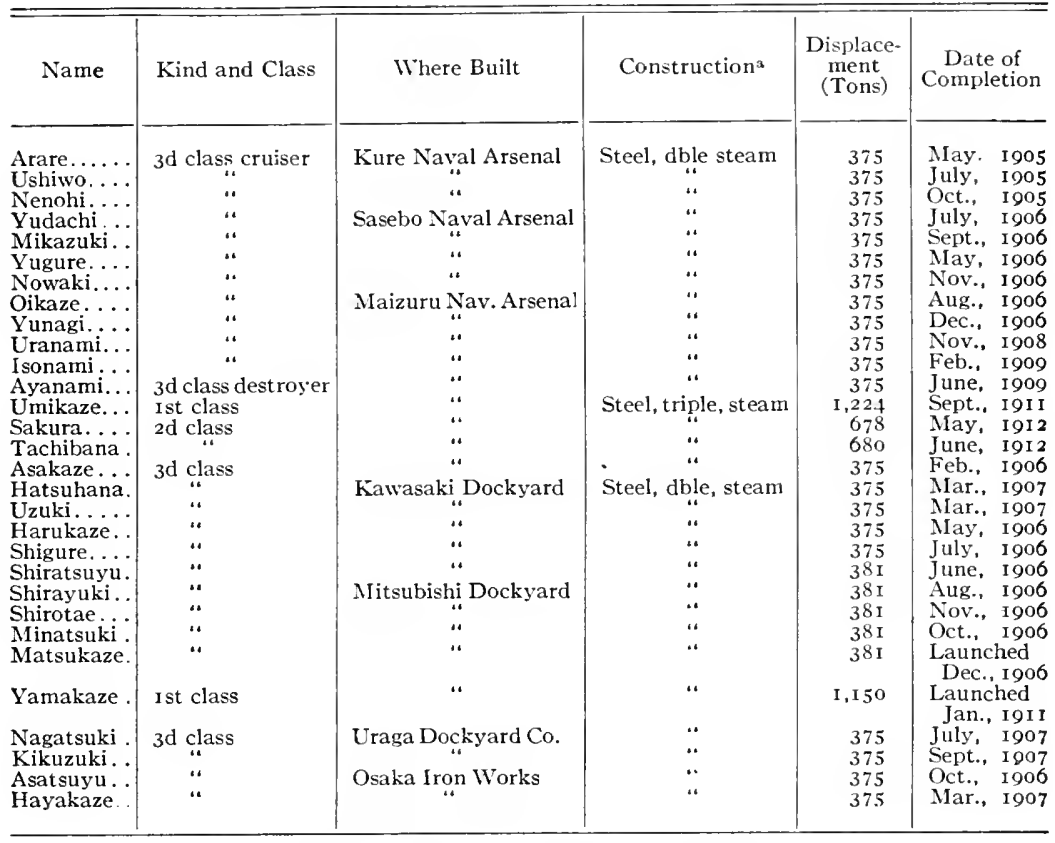

Total: 23 warships: 39 torpedo-boat destroyers.

" "Steel" denotes material used for the ship's hull; "double," "triple, " and " quad " refer to the number of propellers; "steam," steam power.

\section{Torpedo Boats and Submarine Boats}

(I) Torpedo Boats.-The torpedo boat Sagi and four others were built during the Russo-Japanese War, but after the war not one torpedo boat was built, while the building of torpedoboat destroyers was continued as before. The reason is that as a result of experience in that war, the necessity of submarine boats was recognized and in that period this boat was built instead of the torpedo boat, a matter worthy of notice in the 
warship building interests. The torpedo boats completed during the Russo-Japanese War were as follows:

Chronological Table of Construction of Torpedo Boats

(From the Russo-Japanese War to the Present Time)

\begin{tabular}{|c|c|c|c|c|c|}
\hline Name & $\begin{array}{l}\text { Kind and } \\
\text { Class }\end{array}$ & Where Built & Material & $\begin{array}{c}\text { Displacement } \\
\text { Tons }\end{array}$ & $\begin{array}{l}\text { Date of } \\
\text { Completion }\end{array}$ \\
\hline Sagi. & $\begin{array}{c}\text { Ist class } \\
\text { torpedo } \\
\text { loat }\end{array}$ & $\begin{array}{c}\text { Kure Naval } \\
\text { Arsenal }\end{array}$ & Steel & I 50 & Mar., I904 \\
\hline $\begin{array}{l}\text { Uzura ..... } \\
\text { Kamome. }\end{array}$ & "، & "، & "، & “" & $\begin{array}{ll}\text { Apr., } & 1904 \\
\text { June, } & 1004\end{array}$ \\
\hline Hayabusa. & ، & $\begin{array}{l}\text { Kawasaki } \\
\text { Dockvard }\end{array}$ & " & " & Apr., Igo4 \\
\hline Otori & “ & & " & “ & June, 1904 \\
\hline
\end{tabular}

All of the five were first-class boats of the same type; they were entirely the same in displacement, horse power, construction of engine, etc. Their construction was modeled after the I 50-ton boat Hayabusa, made by the Normand Company of France, with some improvements added. They were designed as follows: Displacement, 152 tons; horse power, 3,600; speed, 29 knots. Engine used, double screw, surfacè condensing, vertical, and triple expansion, the cylinder being 16.14 inches, highest pressure, 23.23 inches, mean, and 35 inches, lowest, with stroke of 19.7 inches. Boiler, 2 water-tube boilers of the Normand type, of 803 square feet in grate area and 5,060 square feet in heating surface. Armament, I 57 m.m. quickfiring gun; 247 m. m. quick-firing guns; I I 4.3 in. torpedo tube. The official trial after their completion gave very satisfactory results, especially the speed which showed above the expected 29 knots.

(II) Submarine Boats.-The building of submarine boats was developed after the Russo-Japanese Var, before which Japan had not been advanced enough to build them by herself, and only purchased some from foreign countries. The first 
submarine boat built in Japan was the boat No. 6, completed in April, 39 Meiji (I906), at the Kawasaki Dockyard.

The following are the submarine boats built in Japan, from the beginning:

Chronological Table of the Construction of Submarine Boats

\begin{tabular}{|c|c|c|c|}
\hline Name & Tonnage & Where Built & $\begin{array}{c}\text { Date of } \\
\text { Completion }\end{array}$ \\
\hline 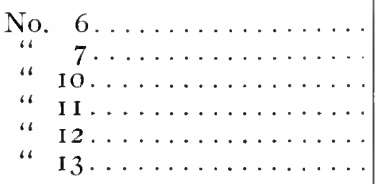 & $\begin{array}{r}62 \\
87 \\
3 \mathrm{I} 4 \\
3 \mathrm{I} 4 \\
3 \mathrm{I} 4 \\
332\end{array}$ & $\begin{array}{c}\text { Kawasaki Dockyard } \\
\text { Kure Naval Arsenal } \\
\text { "“ } \\
\text { Kawasaki Dockyard }\end{array}$ & $\begin{array}{l}\text { Apr., ، } 1906 \\
\text { Aug.,, I9I I } \\
\text { “، } \\
\text { Sept., I9I2 }\end{array}$ \\
\hline
\end{tabular}

Besides the above mentioned war vessels, there are others in the service of the navy. All but warships and torpedo boats belong to the class which includes steamers, boats, and all other kinds of vessels. As most of them were purchased of foreign countries or built at domestic private yards, and only a very few were built at military factories, they are scarcely worth mentioning as products of military industry, and therefore any description of them will be omitted here, except the number and cost of those vessels, as follows:

\begin{tabular}{|c|c|c|}
\hline & Number & $\begin{array}{l}\text { Cost } \\
\text { Yen }\end{array}$ \\
\hline ll sizes) & 348 & $10,44+, 668$ \\
\hline Boa & $2 \mathrm{I}_{4}$ & 123,539 \\
\hline aneous vessels $\ldots \ldots \ldots \ldots \ldots \ldots \ldots \ldots \ldots$ & $\mathrm{I}, 408$ & $8,176.629$ \\
\hline & 1,970 & $\mathbf{1} 8,7$ \\
\hline
\end{tabular}

\section{Repairing of War Vessels and Its Cost}

Before we finish our description of the development of shipbuilding, it must be added that within the sphere of "Naval Industry in War Vessels" comes not only the building of warships, torpedo-boat destroyers and torpedo boats, which we have described, but the repairing of those vessels, as their hulls and engines need repairs from time to time. War 
vessels must enter the dock usually every six months for repairs or repainting, the annual expense for such work amounting to so much that, if all the vessels, from the largest warship. to the smallest torpedo boat or service boat are taken, it would equal about 30 per cent of the cost of the building of war vessels. Therefore the item of "repairing" of war vessels should never be overlooked when naval industry is under consideration. Naval dockyards such as at Sasebo and Maizuru, though fully equipped for any work, have to do repairing as their main object rather than building new ships, simply because they are crowded with repairs. Furthermore, such naval factories as the Ryojun Dockyard, the Ominato Repairing Yard and the Bako Repairing Yard were set up for the special purpose of doing repairing and are all possessed of perfect equipments, yet they are in such a busy state with repairs that "there was never a day long enough for them." From these facts it may be seen how important the repairing industry is. It must be understood, however, that just as repairing is subject to fluctuation in its demand, so its annual showing is mutable. To show how important a place the repairing of war vessels is occupying in naval industry, a table comparing the annual sums of the repairing expense of hulls and engines of ships for five years since 4I Meiji (I908) will be given in the following pages.

Comparison of Annual Expenditures for Repairing of Hulls and ENGINES OF SHIPS

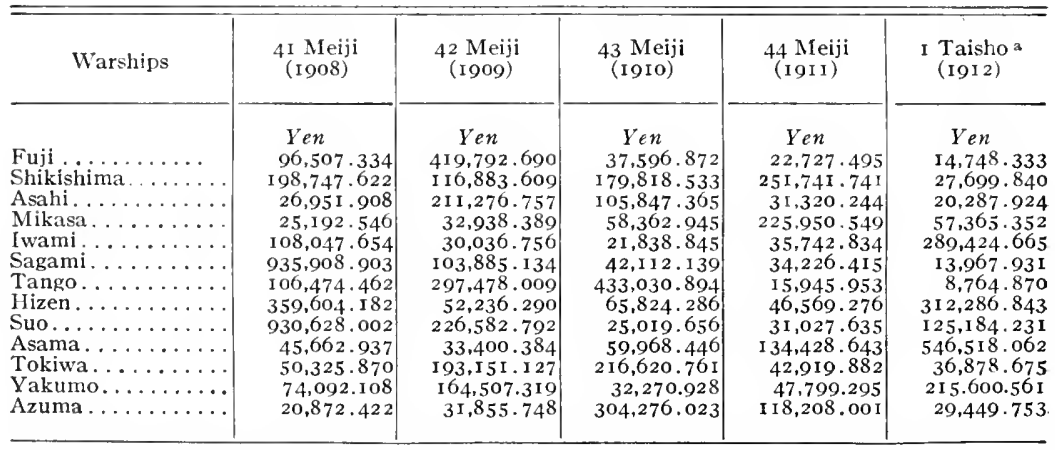

a The repairing expenditure for the 1 st year of Taisho, including that for torpedo boats and miscellaneous ships besides what has been given in the above table, was 5,086,600 yen, which is equal to 28.79 per cent of the building expenditure for the same year, I 7,667, I I yen. 
Comparison of Annual Expenditures for Repairing of Hulls and ENGINES OF SHIPS-Continued

\begin{tabular}{|c|c|c|c|c|c|}
\hline Warships & $\underset{(1908)}{4 I}$ & $\underset{(\mathrm{I} 909)}{42 \mathrm{Meiji}}$ & $\begin{array}{l}43 \text { Meiji } \\
(\text { I } 9 \text { IO) }\end{array}$ & $\underset{(191 \mathrm{I})}{44}$ & $\begin{array}{l}\text { I Taisho }{ }^{a} \\
\text { (I9I2) }\end{array}$ \\
\hline & Yen & Yen & Yen & Yen & Yen \\
\hline Iwate. . . . . . . . & $36,264 \cdot 716$ & $8,138.582$ & $275,349 \cdot 984$ & $21,493 \cdot 453$ & I 5,84 I .824 \\
\hline 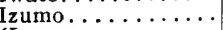 & $45,911.828$ & $41,006.161$ & $32,902.95 \mathrm{I}$ & $86,506.300$ & $263,231.056$ \\
\hline$\ldots \ldots \ldots$ & $22,227.827$ & $14,040.139$ & $48,270 \cdot 383$ & $16,783.926$ & $75,490.767$ \\
\hline Nisshill. . & $22,128,175$ & $29,139 \cdot 905$ & $78,571.893$ & I 7.635 .759 & $95,232.487$ \\
\hline Aso...... & $226,980 \cdot 059$ & $31,991.262$ & $53,83 \mathrm{I} .240$ & $82,751,442$ & I $19,715.906$ \\
\hline Naniwa. & $20,939.692$ & 6.566 .791 & $13,321 \cdot 356$ & $16,627.958$ & I $5,938.570$ \\
\hline Takachio......... & $5,053.506$ & $34,460.818$ & $40,248.100$ & 9.702 .419 & $7,886.304$ \\
\hline Itsukushima . . . . . & $30,036 \cdot 332$ & $34,833.867$ & $26,439 \cdot 479$ & 25.149 .837 & $27,390.882$ \\
\hline Matsushima ....... & 761.600 & & & & \\
\hline Hashidate........ & $24,982.033$ & $12,147.573$ & $28,885 \cdot 289$ & 14.147 .973 & $9,868.821$ \\
\hline Akl $\ldots \ldots \ldots \ldots \ldots$ & $\ldots$ & $\ldots$ & $\ldots$ & $42,980.926$ & $28,448.894$ \\
\hline Kurama........... & $\cdots$ & $\cdots$ & $\cdots$ & $44,671.050$ & $103,096.314$ \\
\hline$\ldots \ldots \ldots$ & $83,49 I \cdot 9 I 4$ & $243,994.034$ & $45,563.82 \mathrm{I}$ & $37,850.905$ & $48,888 \cdot 730$ \\
\hline Chitose.. & $63,091.697$ & I $21,35 \mathrm{I} .81 \mathrm{I}$ & $25,574.002$ & $465,141,966$ & $26,920 \cdot 550$ \\
\hline Tsugaru $\ldots \ldots \ldots$ & $219,785.132$ & $413,529.464$ & $72,121.332$ & $12,417.906$ & $32,808.669$ \\
\hline Soya............. & $190,622.497$ & $55,185.033$ & I $6,849.886$ & $23,025.359$ & $28,163.718$ \\
\hline Izumi... & $6,725 \cdot 548$ & 6.445 .616 & $8,918 \cdot 34 \mathrm{I}$ & $7,995 \cdot 530$ & 169.519 \\
\hline Chiyoda . . & $13,746.053$ & $91,929.576$ & $6,009.600$ & $9,802.75 \mathrm{I}$ & $17,605 \cdot 338$ \\
\hline Akitsushima...... & I $16,401.283$ & $8,37 \mathbf{I}, 038$ & I $2,890.817$ & I $6,294 \cdot 447$ & $13,053.742$ \\
\hline $\operatorname{ma} \ldots \ldots \ldots$ & 85, I I 0.874 & I I ,864 . 239 & I $2,227.846$ & 20.174 .845 & $9,725 \cdot 578$ \\
\hline ashi.......... & $15,263.433$ & $13,466 \cdot 568$ & $104,302 \cdot 580$ & I $82,066$. I I 4 & 2.754 \\
\hline ka............ & $41,424 \cdot 359$ & $32,575.807$ & $8,267 \cdot 556$ & $19,181 \cdot 320$ & $9,404 \cdot 724$ \\
\hline Tsushima......... & $44,832 \cdot 304$ & $40,621 \cdot 338$ & $\mathrm{I} 8,48 \mathrm{I}, \mathrm{I} 44$ & $12,8 I_{4} .8 I_{3}$ & I $6,432.530$ \\
\hline 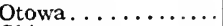 & $14,764.468$ & $10,563.855$ & $9,072 \cdot 793$ & $16,662 \cdot 326$ & $6,777.045$ \\
\hline Chin-en ......... & $14,940.260$ & $13,338.526$ & $1,787.696$ & 2.777 & \\
\hline$\ldots \ldots \ldots \ldots$ & I 54.103 .032 & $83,853.834$ & I $2,222,797$ & $1,179.426$ & 4.360 .995 \\
\hline Okishima. & $35,340.37 \mathrm{I}$ & $25,284 \cdot 583$ & $16,290.614$ & $8,831 \cdot 357$ & $3,619.963$ \\
\hline Mishima. . & $16,755 \cdot 358$ & I $2,334.773$ & $4,642.804$ & I $1,232.582$ & $4,379.044$ \\
\hline go... & $6,810.214$ & & & $\ldots$ & $\ldots$ \\
\hline$\cdots \cdots \cdots \cdots$ & $14,275.75 \mathrm{I}$ & $3,911.927$ & 36.685 & & \\
\hline$\ldots \ldots$ & $8,544 \cdot 476$ & $5,800.282$ & $2,148.19 \mathrm{I}$ & $6,948.181$ & 658.893 \\
\hline$\ldots \ldots \ldots$ & $3,510.455$ & I $8,442 \cdot 459$ & $6,301.714$ & 27.379 .150 & $5,732.050$ \\
\hline Musashi. & $21,282,156$ & $4,994.760$ & $4,392.992$ & $3,787.549$ & I 3,08 I . 961 \\
\hline Takao... & I I, 197.576 & I $1,921.676$ & $1,149.069$ & 2.778 & $\ldots$ \\
\hline Chikuma.. & & & & $2,637.820$ & $27,504.670$ \\
\hline Matsue... & $6,533 \cdot 978$ & $8,342.968$ & 4.533 .136 & $29,78 \mathbf{I} \cdot 430$ & $8,220.476$ \\
\hline$\ldots \ldots$ & $1,285.130$ & & & $\ldots$ & $\ldots$ \\
\hline Akagi. & $3,096 \cdot 764$ & $2,486 \cdot 529$ & 2,8 I0. 280 & 1. 490 & \\
\hline Uji... & I $2,632,643$ & $5, \mathrm{I} 02.280$ & 737.230 & 894.162 & $46,907 \cdot 960$ \\
\hline$\ldots \ldots \ldots$ & I $8,279 \cdot 443$ & $9,211.562$ & $7,315.695$ & $\ldots$ & $\ldots$ \\
\hline$\ldots \ldots \ldots$ & $7,402.703$ & $2,610 . \mathrm{II} 0$ & $9,661.676$ & $2,754 \cdot 134$ & $23,688.099$ \\
\hline$\ldots \ldots \ldots$ & I $4,497.796$ & 6,47 I. 660 & $11,361.498$ & I $0,648.762$ & $76,844 \cdot 4 \mathrm{I} 6$ \\
\hline Manshu. & $22,134.018$ & $13,974.924$ & $5,581.648$ & $9,746.197$ & I $6,628.685$ \\
\hline Toyohashi & $6,461 \cdot 235$ & I $0,173.152$ & $6,398.832$ & $5,593 \cdot 320$ & $2,729.235$ \\
\hline Karasaki. & 17.765 .466 & $7,254 \cdot 222$ & $5,181,780$ & 4.167 .960 & $15,100.504$ \\
\hline Katori.. & $38,292.013$ & $80,669.706$ & $40,486.100$ & $31,791,746$ & $19,469.730$ \\
\hline ida. . & $2,624.037$ & $3,972.708$ & $4,012.035$ & 208.207 & $3,434 \cdot 756$ \\
\hline Anegawa. & $24,656.990$ & $8,307 \cdot 783$ & I $2,076.144$ & $13,546.782$ & $\ldots$ \\
\hline$\ldots$. & II I,9I I . 747 & $416,706.869$ & $6,895 \cdot 265$ & $21,708.692$ & I I, 79 I . 978 \\
\hline$\ldots \ldots$ & I $21,232.008$ & $28,433.046$ & $40,300 \cdot 506$ & $34,040.27 \mathrm{I}$ & $48,060,247$ \\
\hline $\mathrm{Ts}$ & I $91,865.865$ & I $34,099.501$ & $63,170.041$ & 50.435 .869 & I $59,764.768$ \\
\hline Fushimi. & $4,844.735$ & $2,478.860$ & $4,525 \cdot 594$ & 152.193 & $\mathrm{I}, 527.883$ \\
\hline Ikoma. & I $9,793.035$ & $15,730.302$ & $45,180.192$ & $60,295.220$ & $24,199.328$ \\
\hline Yodo. & $5,316.769$ & 4,8 I0.3 I 7 & I I 815.780 & $26,613.087$ & $10,302.376$ \\
\hline Mogami & 3.532 .013 & $4,028.686$ & $13,074.103$ & $9,422,464$ & $5,116.298$ \\
\hline Ibuki. . & $\ldots$ & $20,772.477$ & $39,873 \cdot 546$ & $32,45 \mathrm{I}, 901$ & $47,006.003$ \\
\hline Tone.. & $\ldots$ & $\ldots$ & $23,652.143$ & $16,102.931$ & I $8,413.242$ \\
\hline & $\ldots$ & $\ldots$ & $10,219.47 \mathrm{I}$ & $36,748.912$ & I $57,537.319$ \\
\hline achi & $\ldots$ & $\ldots$ & $\ldots$ & $\ldots$ & $52,195.037$ \\
\hline & $\ldots$ & $\ldots$ & . . & $\ldots$ & $6,287.785$ \\
\hline to. & $\ldots$ & $\ldots$ & $\ldots$ & $\ldots$ & I $2,155.596$ \\
\hline Yahagi. & $\ldots$ & $\ldots$ & & $\ldots$ & $3,257.194$ \\
\hline Toba.. & $\cdots$ & $\cdots$ & $\ldots$ & $\ldots$ & $1,996.977$ \\
\hline Total & $5,230,479.317$ & $4,141,768,963$ & $2,938,523 \cdot 343$ & $2,699,594.638$ & $3,5 \times 2,854 \cdot 230$ \\
\hline
\end{tabular}

a The repairing expenditure for the Ist year of Taisho, including that for torpedo boats and miscellaneous ships besides what has been given in the above table, was $5,086,600$ yen, which is equal to 28.79 per cent of the building expenditure for the same year, $17,667,1$ i 0 yen. 
Comparison of Annual Expenditures for Repairing of Hulls and ENGINES OF SHips-Continued

\begin{tabular}{|c|c|c|c|c|c|}
\hline $\begin{array}{c}\text { Torpedo-Boat } \\
\text { Destroyers }\end{array}$ & $\underset{(\text { I } 908)}{4 \text { Meiji }}$ & $\begin{array}{l}42 \text { Meiji } \\
(\text { I } 909)\end{array}$ & $\begin{array}{l}43 \text { Meiji } \\
\text { (I9IO) }\end{array}$ & $\begin{array}{l}44 \text { Meiji } \\
\text { (I9II) }\end{array}$ & $\begin{array}{l}\text { I Taisho }{ }^{\mathrm{a}} \\
\text { (I912)) }\end{array}$ \\
\hline & Yent & Ien & Yen & Yen & Yen \\
\hline Shinonome........ & $20,088.753$ & $2 \mathrm{I}, 73 \mathrm{I} \cdot 76 \mathrm{I}$ & 3.104 .538 & 4.16 I. I I 7 & $6,437 \cdot 354$ \\
\hline Murakumo....... & $1,899.630$ & 7.076 .517 & $39,970.683$ & $4,370.162$ & $2,474.113$ \\
\hline Yugiri.......... & $18,149.158$ & 3.701 .325 & $3,955.477$ & 9.363 .523 & 3.605 .047 \\
\hline Shiranui.......... & $2,536.336$ & $32,727.026$ & $\mathrm{I}, 787.944$ & $5.590 .77 \mathrm{I}$ & 9.285 .837 \\
\hline Kagero.. & I, 877.918 & $36,652.588$ & I,44I.298 & 3.404 .685 & $4,558.004$ \\
\hline Usugumo. . . . . . . & $4,869.08 \mathrm{I}$ & $27,903.097$ & $10,957.161$ & 3.199 .509 & 4.065 .435 \\
\hline Inazuna. ......... & $16,093.473$ & I 0,23 I. 579 & 3.551 .697 & $\ldots$ & $\ldots$ \\
\hline Ikazuchi.......... & $21,835.765$ & $7,668.03 \mathrm{I}$ & $6,542.543$ & $6,803.06 \mathrm{I}$ & $42,274.96 \mathrm{I}$ \\
\hline Akebono ........... & $5,472$. I 06 & $27,969 \cdot 300$ & 4.791 .089 & $6,248.500$ & 4.730 .427 \\
\hline Sazanami......... & I, I 20.754 & 2.469 .642 & $2,775 \cdot 328$ & $5,664 \cdot 294$ & $7,066.795$ \\
\hline Oboro............ & $6,398.192$ & 5.052 .796 & $38,994 \cdot 513$ & $3,737.172$ & $5,363.787$ \\
\hline Shirakumo. & $4,596.285$ & 46.103 .630 & $4,430.872$ & $5,709.479$ & $3,440.145$ \\
\hline Asajio...... & $4,738.106$ & $46,583.967$ & $4,320.80 \mathrm{I}$ & $5,252 \cdot 348$ & 4.142 .550 \\
\hline Kasumi ... & $20,720 \cdot 763$ & 7.095 .878 & $5.148 .75 \mathrm{I}$ & 3.026 .823 & $9,563.61 \mathrm{I}$ \\
\hline Harusame. & $8,346.059$ & 9.9 I I. 883 & $5,186.926$ & $7,249.094$ & $\ldots$ \\
\hline Murasame. & $4,601.377$ & 7.946 .372 & $4,930.892$ & $6,025.4 \mathrm{I} 3$ & $36,917.131$ \\
\hline Asagiri... & $3,977.098$ & $7.053 .79 \mathrm{I}$ & $5,199.124$ & 78.664 & $44.821 \cdot 369$ \\
\hline Ariake... & $5,955 \cdot 592$ & 4.556 .214 & $22,143, I 05$ & $3,601.947$ & $6,238.740$ \\
\hline Fubuki ......... & $5,424.924$ & $5,214.916$ & $23,191.923$ & $3,846.295$ & $42,847 \cdot 985$ \\
\hline Arare.... & $6,264 \cdot 367$ & $6,808.605$ & $26,566 \cdot 355$ & $5,263 \cdot 548$ & 5.924 .207 \\
\hline Satsuki. & $6,919 \cdot 38.7$ & $11,790.223$ & 3.761 .069 & $4,738.477$ & $8,533.417$ \\
\hline Ushio... & $6,366.003$ & $4,032.739$ & $8,566.859$ & $41,608.687$ & $5,556.799$ \\
\hline Hatsushin & $6,006.674$ & 5.624 .622 & $2,679.752$ & $20,402.609$ & $25,057.082$ \\
\hline Kamikaze. & $6.1+5.557$ & $6,450.510$ & $3,04 \mathrm{I}, 220$ & 4.618 .864 & $36,898.733$ \\
\hline Yayoi.... & $6,213.809$ & $6,204.22 \mathrm{I}$ & $3,991.606$ & $33,949.8$ I I & 5.366 .589 \\
\hline Nenohi... & $5,599.557$ & $2,964 \cdot 995$ & $8,174.455$ & $2,319.110$ & 46.014 .200 \\
\hline Fuzuki... & $73, \mathrm{I} 53.03 \mathrm{I}$ & $5,449.278$ & $4,580.818$ & $4,230.950$ & $13,106.700$ \\
\hline Kisaragi.......... & $5,244 \cdot 394$ & $5,499.25 \mathrm{I}$ & $2,966.713$ & $3,127 \cdot 245$ & 32,733 . I 15 \\
\hline Yamabiko..... & $4 \mathrm{I}, 5 \mathrm{I} 5.688$ & 3.568 .193 & $3,740.788$ & $5,902.184$ & 3.469 .939 \\
\hline Shikinami......... & $25,186.390$ & $25,508.167$ & 33.798. I 30 & $3,025.027$ & $8,521.956$ \\
\hline Makigumo........ & $49,906.759$ & $5,570.283$ & $29,957 \cdot 554$ & $5,695 \cdot 729$ & 560.569 \\
\hline Asakaze... & $6,569 \cdot 303$ & $2,775.995$ & $8,755.271$ & $40,524.064$ & $5 . \mathrm{I} \mathrm{I} 4.80 \mathrm{I}$ \\
\hline Yugure... & $5,140,101$ & $1,868.646$ & 6.384 .098 & I $2,169.217$ & $23,240.305$ \\
\hline Wakaba. . & $\ldots$ & $3.326 .74 \mathrm{I}$ & $9,8 \mathrm{I} 4.58 \mathrm{I}$ & 3.072 .070 & $4 \mathrm{I} .576 .954$ \\
\hline Har & $4,209 \cdot 493$ & 3.901 .824 & $4,988.932$ & $54,507.98 \mathrm{I}$ & 3.544 .950 \\
\hline Oika & 4.284 .795 & I $7,543.783$ & $3,651.254$ & 3.638 .725 & $6,283 \cdot 552$ \\
\hline Hat & 44.497 .286 & 3.578 .693 & $3,631.170$ & $4,11+.750$ & $43,556.775$ \\
\hline$\ldots \ldots$ & 3.972 .672 & $3,260.708$ & $3,202,847$ & $13,004.447$ & $25,657.692$ \\
\hline Yudachi. & 4.892 .890 & 2.770 .135 & 4,342 . O I I & 14.531 .786 & 23.371 .998 \\
\hline Shigure... & $5,129.809$ & 4.487 .525 & 3.946 .307 & 4. I I 2 & $42,957.259$ \\
\hline Asat & $6,240 \cdot 742$ & 4.180 .733 & $8,057.575$ & $3,363.439$ & $36,331.232$ \\
\hline Nowalki. & $2,774.936$ & $2,254.828$ & 5.319 .074 & $5,288.4$ I 3 & $7,784.656$ \\
\hline Minatsuki. & 4.395 .209 & $3.20 \mathrm{I} .905$ & $5,612.16 \mathrm{I}$ & 6.417 .071 & 4.137 .287 \\
\hline kaze........ & $2,280.771$ & $3,239.107$ & 6.859 .142 & 5.163 .628 & 8.89 I . 855 \\
\hline $\mathrm{Hib}$ & $3,421.106$ & $5,17 \mathrm{I} \cdot 540$ & $4,258.131$ & $3,169.116$ & $32,886.779$ \\
\hline Mik & 4.855 .268 & $3,068.013$ & $3,682.940$ & I $1,629 \cdot 356$ & $25,441.037$ \\
\hline Shir & $2,680.268$ & $7,983 \cdot 520$ & 4.766 .454 & $5,024.338$ & $9,863.650$ \\
\hline Hat & 3.835 .225 & $4,642.542$ & $3,731.653$ & 4.317 .635 & $42,610.912$ \\
\hline Umil & $\ldots$ & $\ldots$ & $\ldots$ & 2,97 I. 956 & I $8,497.5$ I 8 \\
\hline Yamakaze. & $\ldots$ & $\ldots$ & $\cdots$ & $1,008.116$ & $1 \mathrm{I}, \mathrm{I} 65.830$ \\
\hline Hayakaze. & $3.797 \cdot 588$ & $3,523 \cdot 312$ & $5,983.632$ & $3,28 \mathrm{I} \cdot 235$ & 4.742 .138 \\
\hline Shirot & $2,709.225$ & $3,418.437$ & $8,076 \cdot 362$ & $6,246.022$ & 9,918 . I 20 \\
\hline Yui & $5,497 \cdot 167$ & $2,463,902$ & 5.777 .481 & $3,463.96 \mathrm{I}$ & $5,610.779$ \\
\hline $\mathrm{U}_{2}$ & $5,276,940$ & I.559.956 & 6.499 .492 & $10,340.960$ & $8,942.089$ \\
\hline $\mathrm{Na}$ & $4,167.1$ I 7 & $2,334.830$ & $6,735.678$ & $6,880.234$ & $10.580 .22 \mathrm{I}$ \\
\hline & 5.582 .673 & $1,761.522$ & $7,713.918$ & 4.867 .418 & 4.407 .860 \\
\hline Ura & $1,066.66 \mathrm{I}$ & $2,863.576$ & $1,510.637$ & $6,643.04 \mathrm{I}$ & $3,886.677$ \\
\hline & $\ldots$ & 893.028 & 911.852 & $4,477.674$ & $5,285.940$ \\
\hline Iso & $\ldots$ & $2,214.614$ & $1,442.346$ & $5,880.009$ & $3,790.887$ \\
\hline Sakura... & $\ldots$ & $\ldots$ & $\ldots$ & $\cdots$ & $2,955.37 \mathrm{I}$ \\
\hline Tachibana & $\cdots$ & $\cdots$ & $\cdots$ & $\cdots$ & $47,419.396$ \\
\hline Total. & 534.510 .228 & $505.4 \mathrm{II} .8 \mathrm{I} 5$ & $459,905.083$ & $480,665.872$ & 950,03 I. I I 7 \\
\hline Grand total.... & $5,76+, 989 \cdot 5+5$ & $4,6+7,180.778$ & $3,398,428 \cdot 426$ & $3,180,260.510$ & $4,462,885 \cdot 347$ \\
\hline
\end{tabular}

a The repairing expenditure for the $\mathrm{s}$ st year of Taisho, including that for torpedo boats and miscellaneous ships besides what has been given in the above table, was $5,086,600$ yen, which is equal to 28.79 per cent of the building expenditure for the same year, 17,667, 1 o yen. 
Cost of Naval Vessels?

(Investigated May 3I, 19 I3)

\begin{tabular}{|c|c|c|c|c|c|c|c|}
\hline \multirow{2}{*}{ Jurisdiction } & \multirow[b]{2}{*}{ Kind of Vessels } & \multicolumn{2}{|c|}{ Previous Year } & \multicolumn{2}{|c|}{ Increase or Decrease } & \multicolumn{2}{|c|}{ Present Year } \\
\hline & & $\begin{array}{c}\text { Num- } \\
\text { ber }\end{array}$ & Cost Yen & $\begin{array}{c}\text { Num- } \\
\text { ber }\end{array}$ & Cost Yen & $\begin{array}{c}\text { Num- } \\
\text { ber }\end{array}$ & Cost Yen \\
\hline \multirow{6}{*}{$\begin{array}{l}\text { Yokosuka Na- } \\
\text { val Station }\end{array}$} & Warships.... & 17 & $51,593,081.645$ & -1 & $-1,281,678.964$ & 16 & $50.311,402.681$ \\
\hline & $\begin{array}{l}\text { destroyers. } \\
\text { Torpedo boats. }\end{array}$ & $\begin{array}{l}18 \\
11\end{array}$ & $\begin{array}{l}5,641,107.742 \\
2,070,874.095\end{array}$ & & & $\begin{array}{l}18 \\
11\end{array}$ & $\begin{array}{l}5,641,107.742 \\
2,070,874.095\end{array}$ \\
\hline & Steamers ..... & 105 & $3,079,565.642$ & $\begin{array}{r}2 \\
-2\end{array}$ & $\begin{array}{r}13,431.148 \\
-64,287.000\end{array}$ & 105 & 3.028 .709 .790 \\
\hline & Boats .......... & 65 & $33,558.852$ & $\begin{array}{r}1 \\
-3\end{array}$ & $-1,505.541$ & 63 & $32,253.311$ \\
\hline & Miscellaneous. & 360 & $2,415,985.775$ & $\begin{array}{r}15 \\
-17 \\
\end{array}$ & $\begin{array}{r}1,392,925.481 \\
-394,827.703 \\
\end{array}$ & 358 & $3,414,083.553$ \\
\hline & Total. & 576 & $64,834,173.751$ & -5 & $-335,742.579$ & 571 & $64,498,431.172$ \\
\hline \multirow[t]{7}{*}{$\underset{\text { Station }}{\text { Kure Naval }}$} & $\begin{array}{l}\text { Warships..... } \\
\text { Torpedo-boat }\end{array}$ & 17 & $54,125,959.860$ & 3 & $\ldots$ & 20 & $54,125,959.860$ \\
\hline & $\begin{array}{l}\text { destroyers : } \\
\text { Torpedo boats. } \\
\text { Submarine }\end{array}$ & $\begin{array}{l}12 \\
10\end{array}$ & $\begin{array}{r}4,302,776.214 \\
780,106.763\end{array}$ & -2 & $-121,021594$ & $\begin{array}{r}12 \\
8\end{array}$ & $\begin{array}{r}4,302,776.214 \\
659,085.169\end{array}$ \\
\hline & $\begin{array}{c}\text { submarine } \\
\text { boats ...... }\end{array}$ & 12 & $3,797,712.339$ & & $\begin{array}{r}144,855.000 \\
29383.920\end{array}$ & 13 & $3,797,712.339$ \\
\hline & Steamers .... & 86 & $4,043,094.462$ & $-10^{2}$ & $-2,111,733.838$ & 78 & $1,960,744.544$ \\
\hline & Boats & 69 & $43,317.269$ & $\begin{array}{r}-3 \\
4\end{array}$ & $\begin{array}{r}-145,000.000 \\
146,624.754\end{array}$ & 66 & $43,172.269$ \\
\hline & Miscellaneous. & 387 & $1,277,519.275$ & -6 & $-204,778.948$ & 385 & $1,219,365.081$ \\
\hline & Total... & 593 & $68,370,486.182$ & -11 & $-2,261,670.706$ & 582 & $66,108,815.476$ \\
\hline \multirow[t]{6}{*}{$\begin{array}{l}\text { Sasebo Naval } \\
\text { Station }\end{array}$} & Warships..... & 18 & $53,986,086.163$ & $\begin{array}{r}1 \\
-1\end{array}$ & $-2,543,261.889$ & 18 & $51,442,424.274$ \\
\hline & $\begin{array}{c}\text { Torpedo-0oat } \\
\text { destroyers.. } \\
\text { Torpedo boats. }\end{array}$ & $\begin{array}{l}19 \\
28\end{array}$ & $\begin{array}{l}8,572,985.410 \\
5,662,556.346\end{array}$ & 2 & 300000 & $\begin{array}{l}21 \\
28\end{array}$ & $\begin{array}{l}8,572,985.410 \\
5,662,956.346\end{array}$ \\
\hline & Steamers ..... & 92 & $2,109,797.272$ & $\begin{array}{r}2 \\
-1\end{array}$ & $\begin{array}{r}390.000 \\
-1,400.000\end{array}$ & 93 & $2,108,787.272$ \\
\hline & Boats ......... & 45 & $33,290.320$ & $\begin{array}{r}-4 \\
12\end{array}$ & $\begin{array}{r}-670.000 \\
2,674.968 .332\end{array}$ & 41 & $32,620.320$ \\
\hline & Miscellaneous. & 400 & $2,324,189.457$ & $\begin{array}{r}12 \\
-23 \\
\end{array}$ & $\begin{array}{r}2,064,908 ., 932 \\
-2,641,791.977 \\
\end{array}$ & 389 & $2,357,365.812$ \\
\hline & Total..... & 602 & $72,688,904.968$ & -12 & $-2,511,765.534$ & 590 & $70,177,139,434$ \\
\hline \multirow[t]{9}{*}{$\begin{array}{l}\text { Maizuru Naval } \\
\text { Station }\end{array}$} & $\begin{array}{l}\text { Warships ..... } \\
\text { Torpedo-boat }\end{array}$ & 11 & $44,648,929.139$ & 2 & . & 12 & $44,648,929.139$ \\
\hline & $\begin{array}{c}\text { destroyers ... } \\
\text { Torpedo boats. }\end{array}$ & $\begin{array}{l}8 \\
8\end{array}$ & $\begin{array}{l}3,282,683.318 \\
1,273,200.630\end{array}$ & ${ }_{1}-1$ & $-129,750.302$ & $\begin{array}{l}8 \\
7\end{array}$ & $\begin{array}{l}3,282,683.318 \\
1,143,450.328\end{array}$ \\
\hline & Steamers..... & $\begin{array}{l}41 \\
32\end{array}$ & $\begin{array}{r}930,777.408 \\
12,922.867\end{array}$ & $\begin{array}{l}-1 \\
-1\end{array}$ & $\begin{array}{l}-480.000 \\
-621.620\end{array}$ & 41 & $930,297.408$ \\
\hline & Miscellaneous. & $\begin{array}{r}32 \\
164\end{array}$ & $\begin{array}{r}12,922.808 \\
1,901,056.768\end{array}$ & $\left\{\begin{array}{r}-1 \\
4 \\
-18\end{array}\right.$ & $\begin{array}{r}154,876.308 \\
-133,776.059 \\
\end{array}$ & $\begin{array}{r}31 \\
150 \\
\end{array}$ & $1,922,157.017$ \\
\hline & Total..... & 264 & $52,049,570.130$ & -15 & $-109,751.673$ & 249 & $51,939,818.457$ \\
\hline & $\begin{array}{l}\text { Steamers. .... } \\
\text { Boats ..... }\end{array}$ & $\begin{array}{r}24 \\
3\end{array}$ & $\begin{array}{r}281,433.226 \\
450000\end{array}$ & 1 & $47,215.088$ & 25 & $328,648.314$ \\
\hline & Miscellaneous & 97 & $257,877.785$ & $\ddot{-}_{2}$ & -600.000 & 95 & $\begin{array}{r}450.000 \\
257,277.785 \\
\end{array}$ \\
\hline & Total..... & 124 & $539,761.011$ & -1 & $46,615.088$ & 123 & $586,376.099$ \\
\hline & Grand total & 2,159 & $258,482,896.042$ & -44 & $-5,172,315.404$ & 2,115 & $253,310,580.633$ \\
\hline
\end{tabular}

1 The values of ships given in this table comprise the values of ships purchased from foreign countries, besides those of the Japanese-built vessels.

In the "increase or decrease" column of the table, the figures marked by the symbol "-" are decreases, and others, not marked, increases. 
In the preceding table is stated the number and cost of all vessels belonging to the Imperial Japanese Navy, in order to show Japan as a naval power, and thereby enable the reader to form an idea of what the construction and repairing of such ships mean to the economy of a country.

\section{Shipbuilding and the Manufacture of Engines}

We will conclude our description of industries relating to warships by summarizing in the following pages the plans of the engine-making industry.

(I) Plans of the Dockyards at the Present Time. (a) The Shipbuilding Department of the Yokosuka Naval Arsenal.-

I. Principal structures are as follows: Docks:

No. I. Length, 364 feet-opened in October, 5 Meiji (I872).

No. 2. Length, 472 feet-opened in June, I7 Meiji (I 884 ).

No. 3. Length, 282 feet-opened in January, 7 Meiji (I874).

No. 4. Length, 574 feet-opened in January, 39 Meiji (1906).

Keel block: 5 .

Factories: small attached structures and structures not directly concerned in the work are omitted.

Drawing Office (2 parts): the main workroom, drawing office store.

Shipbuilding Shed (7 parts): the main factory, the first machine shop, the second machine shop, a bending slab, a forge, two material yards.

Equipment Shop (ro parts) : a mold loft and a machine shop, two iron-working shops, a zinc plating shop, a woodwork mill, a nickel and silver plating shop, a tubework mill, a sawing and planing shop, an erecting shop, a hydraulic testing room.

Ship Repair Shop (ro parts): a machine shop, a painter's 
shop, a boat building shop, a boat shed, the fourth dockmaster's office, a pitch shed, two woodwork mills, a calker's shop, a forge shop. (The pump houses and the like attached to the docks are not enumerated. It will be the same with those under the other arsenals which follow.)

Rigger's Shop (3 parts): the main factory, an anchor factory, two anchor chain tester sheds.

2. A general classification and the number of the machines provided and in use in the above-mentioned factories are as follows:

\begin{tabular}{|c|c|c|c|c|c|}
\hline Engines and Machines & $\begin{array}{l}\text { Hull Con- } \\
\text { struction } \\
\text { Yard }\end{array}$ & $\begin{array}{l}\text { Equipment } \\
\text { Shop }\end{array}$ & $\begin{array}{l}\text { Ship } \\
\text { Repair } \\
\text { Shop }\end{array}$ & $\begin{array}{c}\text { Rigger's } \\
\text { Shop }\end{array}$ & Total \\
\hline 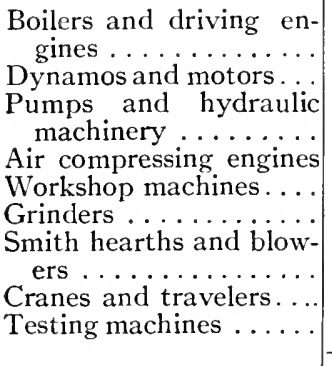 & $\begin{array}{r}\text { I } \\
12 \\
\\
7 \\
2 \\
84 \\
6 \\
\\
57 \\
16 \\
\ldots\end{array}$ & $\begin{array}{r}2 \\
13 \\
\\
3 \\
1 \\
128 \\
11 \\
\\
28 \\
7 \\
\ldots \\
\end{array}$ & $\begin{array}{r}5 \\
. \\
43 \\
8 \\
6 \\
7 \\
\cdots \\
\end{array}$ & $\begin{array}{l}3 \\
3 \\
\ldots \\
\cdots \\
\cdots\end{array}$ & $\begin{array}{r}3 \\
36 \\
15 \\
3 \\
3 \\
255 \\
25 \\
\\
91 \\
46 \\
2\end{array}$ \\
\hline Total . & 185 & $x 93$ & 77 & $2 \mathrm{I}$ & 476 \\
\hline
\end{tabular}

3. Number of workmen engaged in the Yokosuka Naval Shipbuilding Department, on March 20, 3 Taisho (I9I4):

\begin{tabular}{|c|c|c|c|c|c|c|}
\hline Factories & Ordinary & Writers & $\begin{array}{l}\text { Miscel- } \\
\text { laneous }\end{array}$ & $\begin{array}{c}\text { Appren- } \\
\text { tices }\end{array}$ & Females & Total \\
\hline $\begin{array}{l}\text { Manager's office... } \\
\text { Drawing office... } \\
\text { Hull construction } \\
\text { yard.......... } \\
\text { Equipment shop . . } \\
\text { Ship repair shop . . } \\
\text { Rigger's shop... . }\end{array}$ & $\begin{array}{r}83 \\
\\
\mathrm{r}, 292 \\
805 \\
78 \mathrm{r} \\
255\end{array}$ & $\begin{array}{l}\cdots \\
\cdots \\
\cdots\end{array}$ & $\begin{array}{l}4 \\
6 \\
7 \\
7 \\
3\end{array}$ & $\begin{array}{r}45 \\
29 \\
56 \\
7 \\
\cdots\end{array}$ & $\begin{array}{r}\cdots \\
\cdots \\
8 \\
21 \\
6 \\
\cdots\end{array}$ & $\begin{array}{r}41 \\
132 \\
\\
\mathrm{I}, 335 \\
889 \\
801 \\
258\end{array}$ \\
\hline Total....... & 3,216 & $4 \mathrm{I}$ & 27 & 137 & 35 & 3,456 \\
\hline
\end{tabular}


(b) The Shipbuilding Department of the Kure Naval Arsenal.-

I. Principal structures are as follows:

Docks:

No. I. Length, 408 feet-opened in March, 2 I Meiji (I 888).

No. 2. Length, 478 feet-opened in March, 3I Meiji (1898).

No. 3. Length, 744 feet-opened in March, 45 Meiji (I9I2).

No. 4. (For building ships.) Length, 7 I 7 feet-opened in March, 45 Meiji (I9I2).

Keel block: 3 .

Factories: small attached structures and structures not directly concerned in the work are omitted.

Drawing Office (2 parts): the main workroom, a drawing office store.

Shipbuilding Shed (I 7 parts): a plater's yard and mold loft ( 2 parts), a joiner's shop and a store, a galvanizing shop, an angle smith shop, a fitter's shop, a rivet forge, a sawmill, electric sub-station and shed ( 2 parts), a bending slab and a tool repairing shop, an equipment shop, a plumber's shop and an angle smith shop, a blacksmith shop, a plate shed and a machine shop and a plumber's shop for constructor's department.

Ship Repair Shop (5 parts): the main workshop, a pitch shed, a paint store, a painting oil boiling shed, a dock master's store.

Rigger's Shop (3 parts): the main workshop, an anchor tester shed, a tar shed.

2. A general classification and the number of the machines provided and in use in the above-mentioned factories are as follows: 


\begin{tabular}{|c|c|c|c|c|c|}
\hline Engines & $\begin{array}{l}\text { Hull Con- } \\
\text { struction } \\
\text { Yard }\end{array}$ & $\begin{array}{l}\text { Ship } \\
\text { Repair } \\
\text { Shop }\end{array}$ & $\begin{array}{l}\text { Rigger's } \\
\text { Shop }\end{array}$ & $\begin{array}{l}\text { Manager's } \\
\text { Office }\end{array}$ & Total \\
\hline $\begin{array}{l}\text { Boilers and driving en- } \\
\text { gines } \ldots \ldots \ldots \ldots \ldots\end{array}$ & 8 & 3 & ․ & 4 & \\
\hline Dynamos and motors & 26 & & $\cdots$ & 4 & 26 \\
\hline $\begin{array}{l}\text { Pump and hydraulic } \\
\text { machinery }\end{array}$ & & & & & \\
\hline $\begin{array}{c}\text { machinery } \ldots \ldots \ldots \\
\text { Air compressing engines }\end{array}$ & 16 & IO & .. & . & 26 \\
\hline $\begin{array}{l}\text { Air compressing engines } \\
\text { Workshop machines.... }\end{array}$ & 6 & . & . & . & 6 \\
\hline $\begin{array}{l}\text { IVorkshop machines.... } \\
\text { Grinders . . . . . . . . }\end{array}$ & 29 I & 4 & 4 & 2 & 301 \\
\hline $\begin{array}{l}\text { Grinders. } \\
\text { Smith hearths and blow- }\end{array}$ & 35 & & 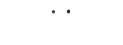 & . & 35 \\
\hline & 92 & .. & . & . & 92 \\
\hline Cranes and travellers... & 22 & .. & . & 44 & 66 \\
\hline Testing machines & . & . & . & I & $\mathbf{I}$ \\
\hline Total & +96 & I7 & 4 & $5 \mathrm{I}$ & 568 \\
\hline
\end{tabular}

3. Number of workmen employed in the Shipbuilding Department of the Kure Naval Arsenal, March 20, 3 Taisho (I9I4):

\begin{tabular}{|c|c|c|c|c|c|c|}
\hline Factories & Ordinary & Writers & $\begin{array}{l}\text { Miscel- } \\
\text { laneous }\end{array}$ & $\begin{array}{c}\text { Appren- } \\
\text { tices }\end{array}$ & Females & Total \\
\hline Manager's offic & & 28 & 8 & . & . & 36 \\
\hline $\begin{array}{l}\text { Drawing office... } \\
\text { Hull construction }\end{array}$ & 87 & I & 4 & 49 & . & $14 \mathrm{I}$ \\
\hline 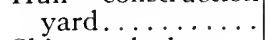 & $2, \mathrm{I} 12$ & 27 & 32 & 94 & $\cdots$ & 2,265 \\
\hline Ship repair shop. & 228 & $\mathrm{I}$ & 4 & I & $\cdots$ & 234 \\
\hline Rigger's shop. & 66 & 2 & 216 & $\ldots$ & . & 284 \\
\hline Total. & 2,493 & 59 & 264 & I 44 & . & 2,960 \\
\hline
\end{tabular}

(c) The Shipbuilding Department of the Sasebo Naval Arsenal.-

I. Principal structures are as follows:

Docks:

No. I. Length, 430 feet-opened in October, 28 Meiji (1895).

No. 3. Length, 57 I feet-opened in June, 38 Meiji (1905). 
No. 4. Length, 767 feet-opened in April, 38 Meiji (1905).

No. 5. Length, 6Io feet-opened in April, 38 Meiji (I905).

No. 6. Length, 486 feet-opened in April, 38 Meiji (I905).

Keel block: 4 .

Factories:

Drawing Office (2 parts): the main workroom, a drawing office store.

Shipbuilding Shed (8 parts): the main factory, a woodwork shop, and mold loft works, three shipbuilding machine shops, two forges, a galvanizing shop.

Ship Repair Shop (8 parts): the main workshop, a sawmill, a boat building shop, a boat shed, a pitch shed, painter's shop, a ship repair shop, two working shops. Rigger's Shop (2 parts): the main factory, rigger's shop store.

2. A general classification and the number of the machines provided and in use in the above-mentioned factories are as follows:

\begin{tabular}{|c|c|c|c|c|}
\hline Machines & $\begin{array}{c}\text { Shipbuilding } \\
\text { Shed }\end{array}$ & $\begin{array}{l}\text { Ship Repair } \\
\text { Shop }\end{array}$ & $\begin{array}{l}\text { Rigger's } \\
\text { Shop }\end{array}$ & Total \\
\hline 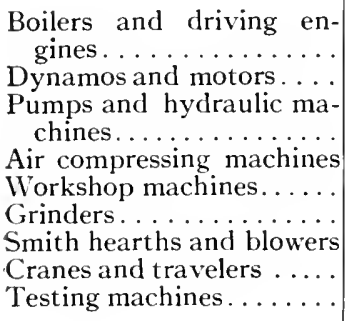 & $\begin{array}{r}3 \\
3 \\
10 \\
4 \\
143 \\
20 \\
56 \\
12 \\
\cdots\end{array}$ & $\begin{array}{r}9 \\
2 \\
\text { I } 8 \\
\text { I } 8 \\
\text { I } \\
8 \\
\text { I } 6 \\
\ldots\end{array}$ & $\begin{array}{l}\cdots \\
\cdots \\
\cdots \\
\cdots \\
\cdots \\
\mathrm{I} \\
\cdots \\
5 \\
\mathrm{I}\end{array}$ & $\begin{array}{r}12 \\
5 \\
28 \\
4 \\
161 \\
32 \\
64 \\
33 \\
1\end{array}$ \\
\hline Total. . & $25 \mathrm{I}$ & 82 & 7 & 340 \\
\hline
\end{tabular}


3. The number of workmen at work in the Shipbuilding Department of the Sasebo Naval Arsenal, on March 20, 3 Taisho (I9I4), is as follows:

\begin{tabular}{|c|c|c|c|c|c|c|}
\hline Factories & Ordinary & Writers & $\begin{array}{l}\text { Miscel- } \\
\text { laneous }\end{array}$ & $\begin{array}{c}\text { Appren- } \\
\text { tices }\end{array}$ & Females & Total \\
\hline $\begin{array}{l}\text { Manager's office.... } \\
\text { Drawing office ... } \\
\text { Shipbuilding shed } \\
\text { Ship repair shop... } \\
\text { Rigger's shop.... }\end{array}$ & $\begin{array}{r}7 \\
29 \\
828 \\
239 \\
98\end{array}$ & $\begin{array}{r}13 \\
1 \\
6 \\
3 \\
2\end{array}$ & $\begin{array}{r}2 \\
2 \\
69 \\
32 \\
42\end{array}$ & $\begin{array}{r}36 \\
26 \\
47 \\
3 \\
1\end{array}$ & $\begin{array}{l}\cdots \\
\because \\
4 \\
\cdots \\
\cdots\end{array}$ & $\begin{array}{r}15 \\
58 \\
954 \\
277 \\
143\end{array}$ \\
\hline Total & I, I 94 & 25 & 147 & 77 & 4 & $\mathbf{r}, 447$ \\
\hline
\end{tabular}

(d) The Shipbuilding Department of the Maizuru Naval Arsenal.--

I. The principal structures are as follows:

Docks:

No. I for torpedo boat. Length, 249 feet-opened in October, 35 Meiji (I 902).

No. 2 for torpedo boat. Length, 190 feet-opened in October, 35 Meiji (I902).

No. 3. Length, 528 feet-opened in March, 37 Meiji (I904).

Keel block: 3 .

Factories:

Drawing Office (2 parts): the main workroom, and drawing office store.

Shipbuilding Shed (6 parts) : (a) a woodwork shop and a sawmill, an angle iron shop, a galvanizing shop, a bending slab, a blacksmith shop and a copper shed, an iron works. (b) A woodwork shop and a mold loft.

Ship Repair Shop (6 parts) : a pitch shed, a painter's shop and calker's shop ( 2 parts), a paint store, a shore shed, a boat shed.

Rigger's Shop (3 parts): the main factory, a rigger's store, an anchor tester shed. 
2. A general classification and the number of machines provided and in use in the above-mentioned factories are as follows:

\begin{tabular}{|c|c|c|c|c|}
\hline Machines & $\begin{array}{c}\text { Shipbuilding } \\
\text { Shed }\end{array}$ & $\begin{array}{l}\text { Ship Repair } \\
\text { Shop }\end{array}$ & $\begin{array}{l}\text { Rigger's } \\
\text { Shop }\end{array}$ & Total \\
\hline 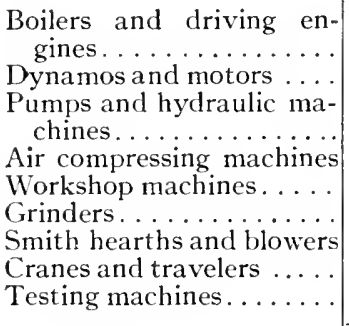 & $\begin{array}{r}\cdots \\
4 \\
12 \\
3 \\
14 \mathrm{I} \\
24 \\
30 \\
7 \\
1\end{array}$ & $\begin{array}{l}4 \\
\cdots \\
\text { I0 } \\
\cdots \\
\cdots \\
3 \\
\cdots \\
5 \\
\cdots\end{array}$ & $\begin{array}{l}\cdots \\
\cdots \\
\cdots \\
\cdots \\
\cdots \\
\cdots \\
10 \\
3\end{array}$ & $\begin{array}{r}4 \\
4 \\
22 \\
3 \\
14 \mathrm{I} \\
27 \\
30 \\
22 \\
4\end{array}$ \\
\hline Total. & 222 & 22 & I 3 & 257 \\
\hline
\end{tabular}

3. The number of workmen at work in the Shipbuilding Department of the Maizuru Naval Arsenal, on March 20, 3 Taisho (I9I4):

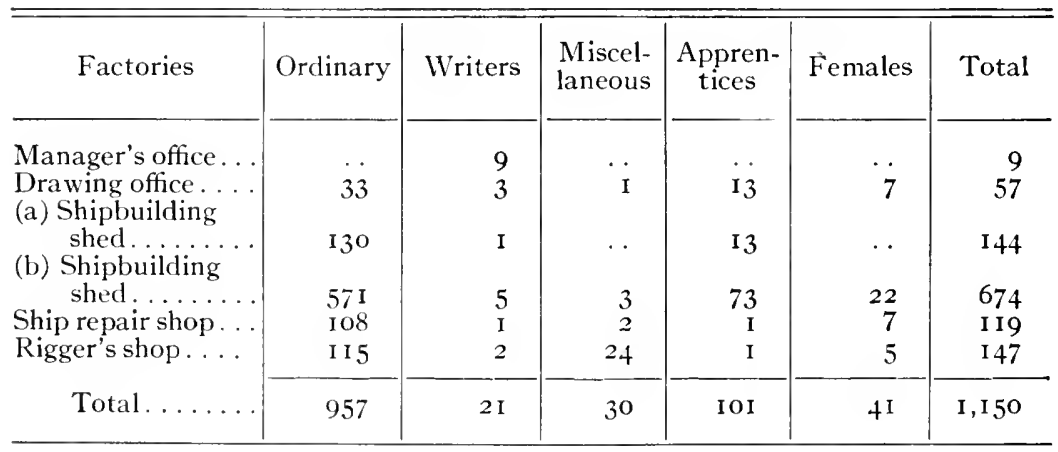

(II) The Engine-making Industry.-The first launching of a warship of the Western type in the navy of Japan was performed in 3 Bunkyu (I863), five years before the era of Meiji, when the warship Chiyoda was launched. To give some main points, for example, the warship Chiyoda was I 40 tons in displacement, 96 feet in length, with 60 horse power in engine. She could hardly be called a warship, but was rather akin to an 
auxiliary ship, in the sense in which those terms are applied nowadays.

The progress of engine making from the beginning of Meiji to the Sino-Japanese IVar was very slow. Of all the engines built in this period, one for the warship Akitsushima was the largest, and yet its actual horse power was only 5,000 or more. The industry as carried on by the navy after that time remained almost unchanged until the Russo-Japanese War, and the perfection of the equipment for future work was the chief object of effort.

Whereas all the engines built before the Sino-Japanese War were longitudinal, vertical engines were adopted for all ships built after the war; and whereas formerly only cylindrical boilers had been used, Normand boilers were placed in the warship Chihaya, Niclausse boilers in the warships Niitaka and Tsushima, and water-tube boilers of the "Navy" type in the warship Otowa.

The invention of the Miyabara water-tube boiler is, with its adoption by the navy, a notable event. The details of its construction can not be described here, but at any rate it is a matter of some encouragement to the Japanese that an invention was made in this country by which they can make their boilers at home, when all of the many water-tube boilers used in the Japanese Navy were of foreign invention, most being made in England, France and other countries.

The first adoption of that boiler was at the time when in 34 Meiji (I9II) the boilers of the warship Hashidate were replaced. The result of this adoption was very satisfactory, and the boiler has been used for most of the battleships and cruisers built since that time. While the development of the engine-making industry up to the Russo-Japanese War is as briefly stated above, the results of the war, with the completion of the equipment of the factories, opened an epoch in the history of said industry, and put Japan in a position to make at one bound engines for armored cruisers and further those for dreadnoughts and super-dreadnoughts, as will be shown in the table given on pages ${ }_{5}{ }^{\circ}$ and I 5 I. 


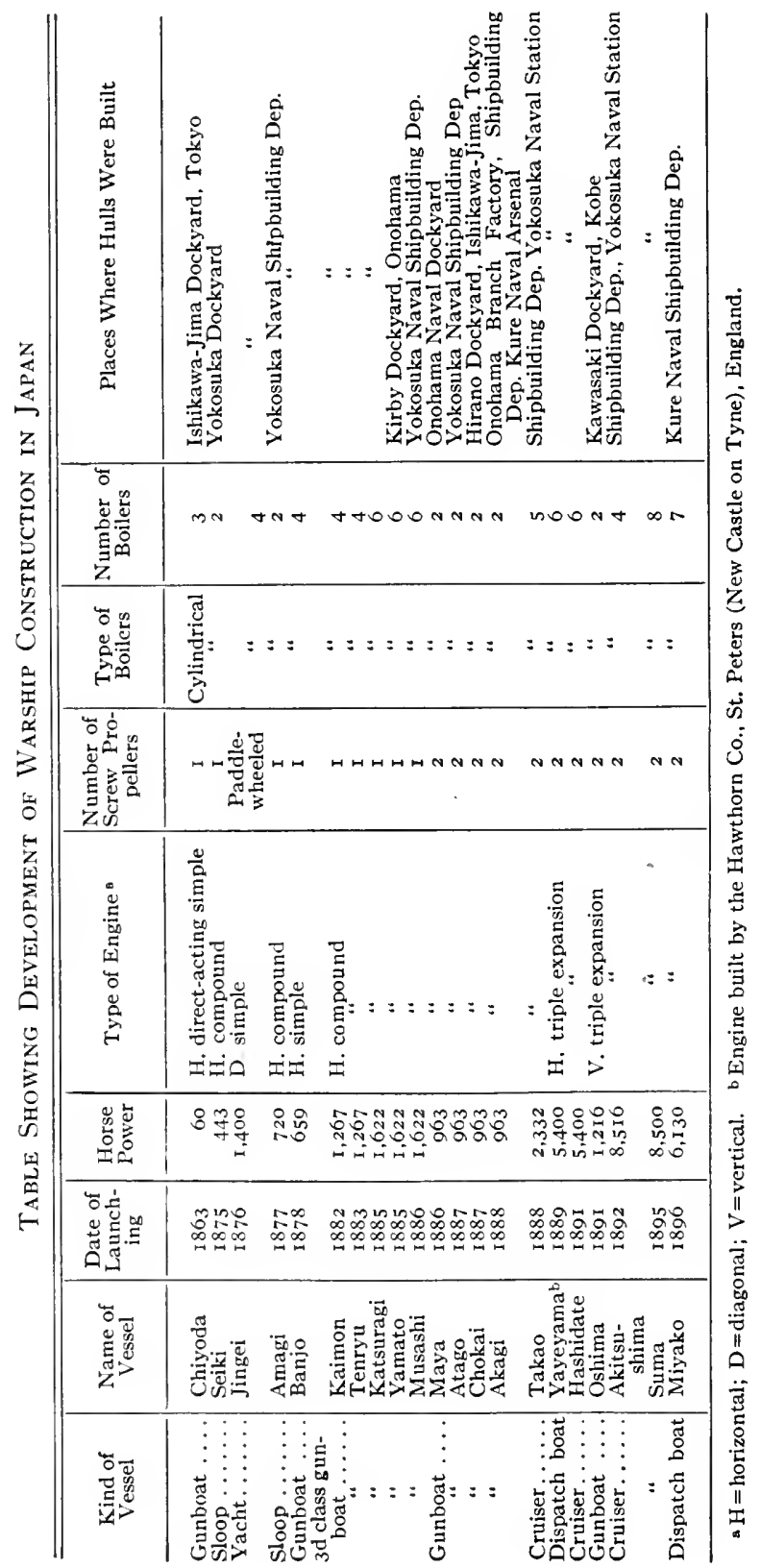




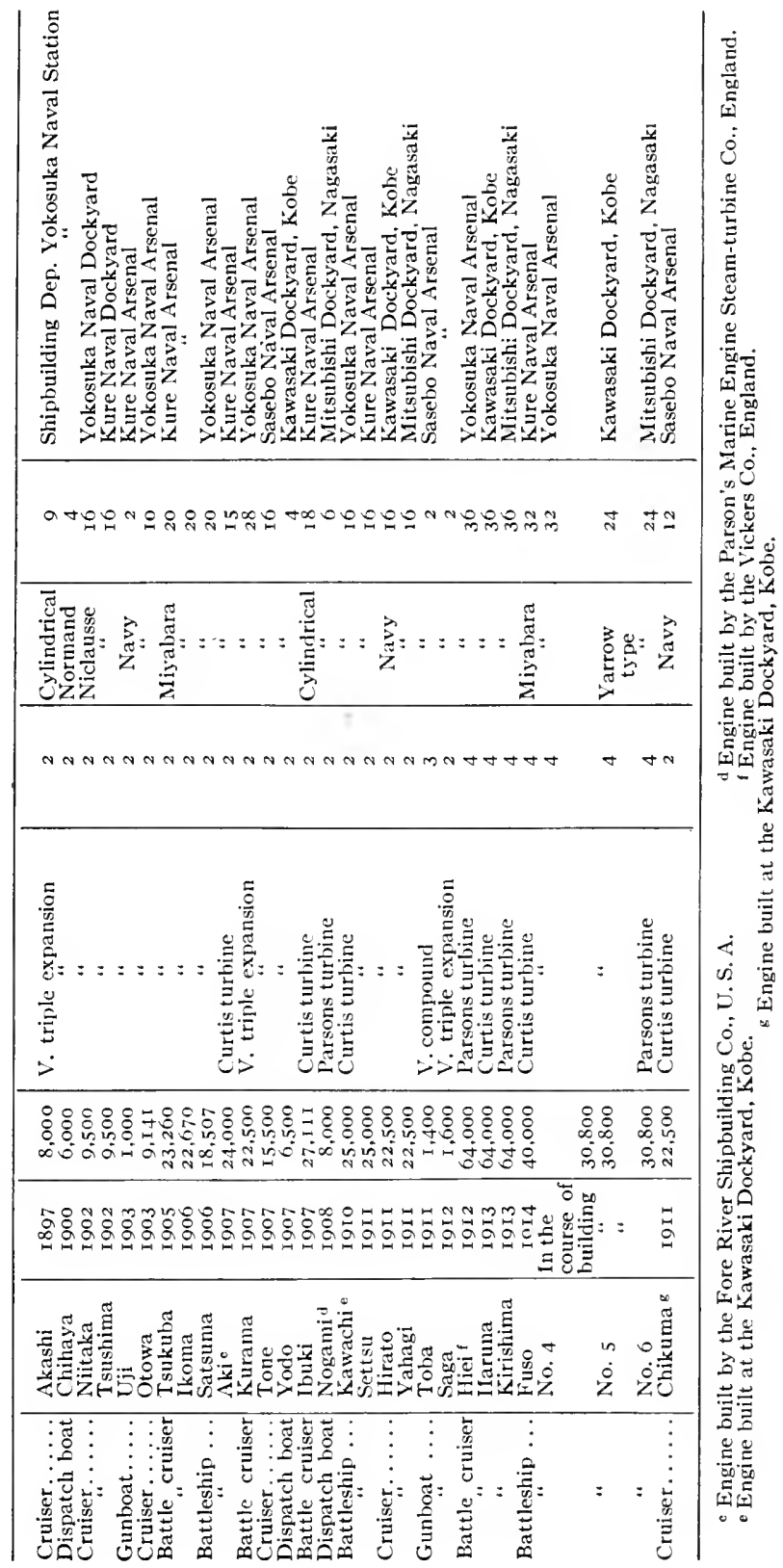




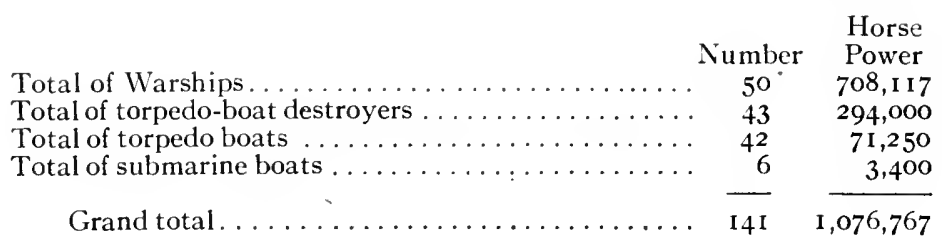

At present, factories owned by the navy for engine making are four (at Yokosuka, Kure, Sasebo and Maizuru), and three at the secondary naval stations at Ominato, Bako and Ryojun. The working arrangement of these factories is, briefly, as follows: Building area of all structures: 32,550 tsubo (about 26.6 acres); number of machines: 2,620; workmen (round number): 8,400 .

As the amount of work of engine making in the naval arsenals is generally determined by that of the work of shipbuilding, which is necessarily unsteady, advancement in the same industry can not well be shown by figures; but advance or increase of manufacturing capacity may be observed from the table on the preceding pages, in which the engine power is given for each ship.

\section{Fuel}

(I) The Naval Colliery.-The Naval Colliery has under its jurisdiction the Shimbara Coal Mine and the Omine Coal Mine. From the days before the Restoration, domestic coal was mostly used by the Japanese Navy as fuel both for its factories and war vessels. But there was also no small amount of foreign coal imported, especially English coal, the supply of which was depended upon for warships every year. It was thought not only necessary for the sake of independence of fueling in war time, but also advantageous from the economical point of view in time of peace, to have under the control of the navy some coal mines in this country rich in good coal. In January, 2 I Meiji (I888), the coal mine at Shimbara, Sue 
Mura, Kasuya District, Fukuoka Prefecture, was appointed as a reserve mine of the navy, for the mining of which a committee was appointed in November, 22 Meiji (1889), and operations were then started. In March, 23 Meiji (1890), the Shimbara Colliery was established, and, its work being carried on directly by the Navy Department, it was assigned to the Special Accounts. In August, 33 Meiji (1900), the name of the mining office was changed to the present one, the Naval Colliery. The government has another coal mine extending over the Village of Katsuno and two other villages in Kurate District, Chikuzen Province, but the mining there is done by contract.

The mine lots in the above two places are four in all, containing an area of $2,622,560$ tsubo (about 2,143 acres), and the output of coal in the fiscal year of I Taisho (I9I2) amounted to $402,414,519 \mathrm{kgs}$.

The yields of the Shimbara Coal Mine directly carried on by the Navy Department are of five sorts, the Shimbara lump, the Shimbara dust, the Shimbara mixed, the Shimbara lump for miscellaneous use, and the Shimbara bad coal, the total output of which in the last five years is as follows:

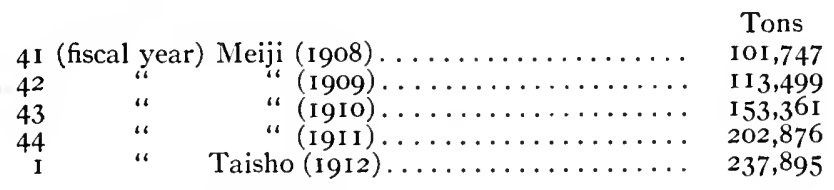

The expense for operation of the same colliery in I Taisho (1912) was something over 2,624,946 yen, and the income, over $2,700,910$ yen, and the difference of more than 75,963 yen, being net profit, was transferred to the General Income Account. The net profit wasover 5.2 percent on the total capital of $\mathrm{r}, 444,500$ yen invested in the same year, consisting of $1,344,-$ 500 yen fixed capital and 100,000 yen working capital.

The first table on the following page shows the profit and loss in the work of the Naval Colliery in the last five years. 


\begin{tabular}{|c|c|c|c|c|c|}
\hline $\begin{array}{l}\text { Years } \\
\text { (fiscal) }\end{array}$ & Profit & Fixed Capital & $\begin{array}{l}\text { Working } \\
\text { Capital }\end{array}$ & Total Capital & $\begin{array}{c}\text { Profit } \\
\text { Pro } \\
\text { Rata to } \\
\text { Total Capital }\end{array}$ \\
\hline 1908. & $\begin{array}{c}Y e n \\
43,686.000\end{array}$ & $\begin{array}{c}Y e n \\
560,632 \text {. I } 10\end{array}$ & $\begin{array}{c}\text { Yen } \\
\text { 100,000.000 }\end{array}$ & $\begin{array}{c}\text { Yen } \\
660,632 \text {. п го }\end{array}$ & $6.6 \mathrm{I}$ \\
\hline I909. & $83,874.624$ & $585,676.563$ & $100,000.000$ & $685,676 \cdot 563$ & 12.22 \\
\hline 1910. & İo3,039. I6o & $589,224.739$ & $100,000.000$ & $689,224 \cdot 739$ & I 4.95 \\
\hline I9II. & $78,618.292$ & $585,806.66 \mathrm{I}$ & $100,000.000$ & $685,806.66 \mathrm{I}$ & I I. 46 \\
\hline 1912. & $75,963 \cdot 394$ & $\mathrm{I}, 344,500.04 \mathrm{I}$ & $100,000.000$ & $\mathrm{I}, 444,500.04 \mathrm{I}$ & 5.20 \\
\hline
\end{tabular}

In addition to the above-mentioned mines, the government owns a coal mine at Omine Village, Mine District, Nagato Province. It was bought up by the navy from a private company in April, 37 Meiji (1904), and when in April of the next year the Temporary Naval Briquette Manufactory was established, a mining branch of the same factory was started at this place, and the old company's name was consequently changed to the Mining Branch of the Briquette Manufactory; but in April, 45 Meiji (I9I2), the mine was taken out of the jurisdiction of the Briquette Manufactory and combined with the Naval Colliery. At the present time the work is not performed directly by the Colliery, but by private individuals on contract.

This mine has for its object the mining of smokeless coal for the use of the Naval Briquette Manufactory. It is covered by one mine lot which has an area of 6,683,920 tsubo (about 5,477 acres). Yearly outputs of the same mine from 4 I Meiji (I908) to I Taisho (I9I2) are as follows:

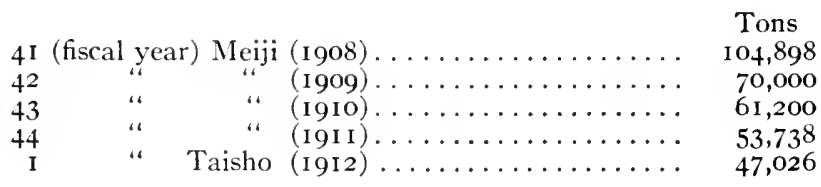


(II) The Naval Briquette Manufactory.--The work in the Naval Briquette Manufactory aims mainly at making briquette for war vessels, to be used mostly in war time and only in practice or trials in time of peace. As Japan is well supplied with smokeless coal, the navy was not slow in making a study of briquette making, and in fact had finished it, when, on account of the Russo-Japanese War in 37 Meiji (1904), it was confronted with the necessity of smokeless fuel, and in July of the same year an office for naval briquette making was set up at Tokuyama, Yamaguchi Prefecture. The establishment was, in April of the next year, named the Temporary Naval Briquette Manufactory, and placing its Briquette Making Department at Tokuyama and Mining Branch at Omine, started its briquette-making work in May of the same year. In January, 39 Meiji (1906), its name was changed to the Naval Briquette Manufactory. In April, 45 Meiji (I9I2), the Omine Mining Branch was transferred to the jurisdiction of the Naval Colliery.

The general condition of the work in the same manufactory is as follows (Ist fiscal year, Taisho-I9I2): Fixed capital, I,200,000 yen; factories, 6; motors, 8,766 horse power; coal consumed (in a year), I 1,626 tons; workmen, actual number, 2 I2 (at the end of I (fiscal) Taisho-I9I2). Working number, 82,579 ; coal carriers, average, about 500 ; expenses for material, $2,613,563.54$ yen; expenses for making briquette, $147,167.18$ yen.

We have completed our description of the outline of the naval industry in Japan, and shall now give a view of the plan of the factories by adding hereto a table containing a summary of the engines used in the naval industries and a table showing the number of persons employed in the naval factories, according to latest investigations: 
Summary of Engines Used in Naval Industry

(Taken at the end of March, 2 Taisho-igr3)

\begin{tabular}{|c|c|c|c|c|}
\hline \multirow{2}{*}{ Factories } & \multicolumn{2}{|c|}{ Engines } & \multicolumn{2}{|c|}{ Coal Consumed } \\
\hline & Number & $\begin{array}{l}\text { Horse } \\
\text { Power }\end{array}$ & Quantity & Value \\
\hline $\begin{array}{l}\text { Yokosuka Naval Arsenal: } \\
\text { Construction Branch } \ldots \ldots \ldots \ldots \\
\text { Dockyard................... } \\
\text { Engineering Branch..... }\end{array}$ & $\begin{array}{r}12 \\
4 \\
9\end{array}$ & $\begin{array}{r}2,865 \\
144 \\
\mathrm{I}, 360\end{array}$ & $\begin{array}{l}\text { Tons } \\
5,386,900 \\
4,773,000 \\
5,537,900\end{array}$ & $\begin{array}{l}\text { Yen } \\
40,134 \\
26,066 \\
38,895\end{array}$ \\
\hline Total............ & 25 & 4,369 & I $5,697,800$ & 105,095 \\
\hline 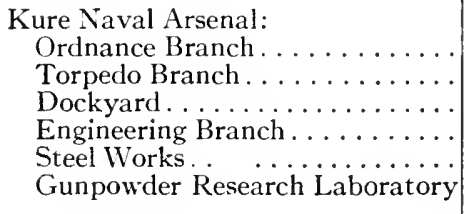 & $\begin{array}{r}158 \\
28 \\
145 \\
135 \\
317 \\
2\end{array}$ & $\begin{array}{r}5,948 \\
7,760 \\
6,179 \\
3,666 \\
29,811 \\
37\end{array}$ & $\begin{array}{r}8,458,601 \\
21,543,980 \\
4,595,000 \\
72,267,375 \\
725,512\end{array}$ & $\begin{array}{r}49,768 \\
\text { I } 6,084 \\
27,230 \\
\ldots \ldots \\
389,775 \\
5,060\end{array}$ \\
\hline Total.... & 785 & 53,401 & $107,690,468$ & 587,917 \\
\hline 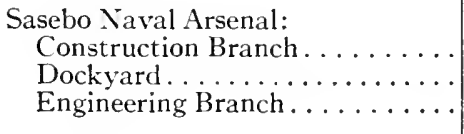 & $\begin{array}{l}6 \\
4 \\
2\end{array}$ & $\begin{array}{r}5,530 \\
155 \\
28 \\
\end{array}$ & $\begin{array}{l}4,962,600 \\
3,074,500 \\
4,156,614\end{array}$ & $\begin{array}{l}22,597 \\
14,680 \\
19,214 \\
\end{array}$ \\
\hline Total. & 12 & $5,7 \times 3$ & $12,193,714$ & $56,49 \mathrm{I}$ \\
\hline 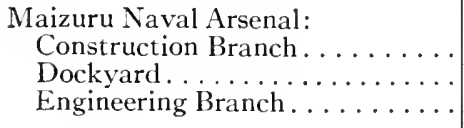 & $\begin{array}{r}48 \\
104 \\
102\end{array}$ & $\begin{array}{l}2,684 \\
2,314 \\
1,602\end{array}$ & $\begin{array}{r}13,623,4 \text { I } 8 \\
376,570 \\
533,928\end{array}$ & $\begin{array}{r}86,876 \\
4,089 \\
5,695\end{array}$ \\
\hline Total.... & 254 & 6,600 & $14,533,916$ & 96,660 \\
\hline 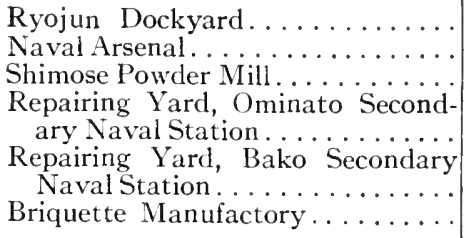 & $\begin{array}{r}\text { I I } \\
4 \\
\text { I }\end{array}$ & $\begin{array}{r}507 \\
535 \\
62 \\
\\
140\end{array}$ & $\begin{array}{r}\mathrm{I}, 875,250 \\
3,48 \mathrm{I}, 49 \mathrm{I} \\
2,065,670 \\
97 \mathrm{I}, 030 \\
\\
299,200 \\
\mathrm{II}, 8 \mathrm{I} 5,960\end{array}$ & $\begin{array}{r}11,730 \\
21,410 \\
14,372 \\
7,089 \\
1,809 \\
55,953\end{array}$ \\
\hline Total. .. & 28 & 2,060 & $20,508,60 \mathrm{I}$ & I 12,363 \\
\hline Grand total. & $\mathrm{I}, \mathrm{IO}_{4}$ & 73,853 & $170,624,499$ & $95^{8,526}$ \\
\hline
\end{tabular}




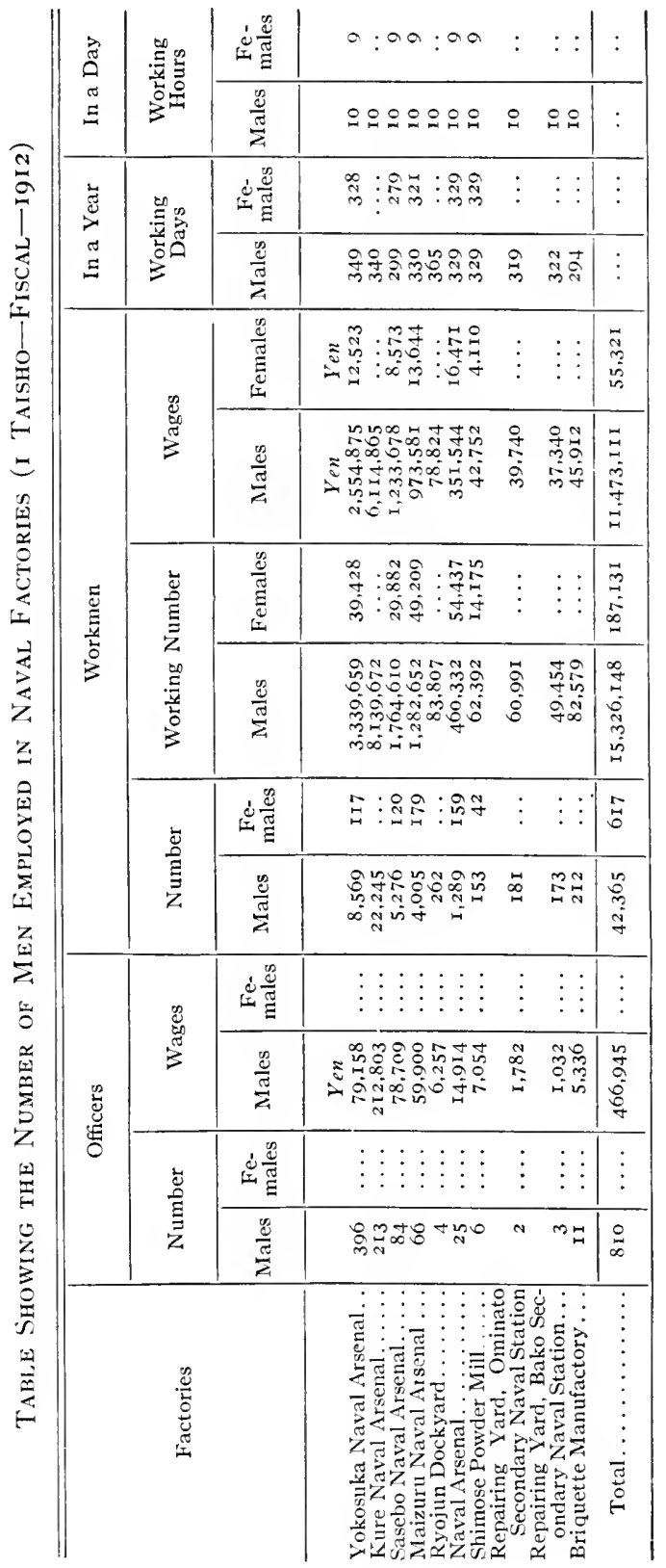





\section{PART II \\ ECONOMIC EFFECTS OF THE MILITARY INDUSTRIES}





\section{CHAPTER I}

\section{INTRODUCTION}

The military industries consist of the manufacture of materials essential to the organization of bodies of military forces. The materials include all varieties of articles from arms, war vessels, tools, and machinery, to supplies, such as clothing, food, fuel, etc. As military or naval powers, which would maintain independence in war, must spend a greater part of their war funds for these materials, this industry has much to do with their finance. Of late years, Japan has spent in this line above 40 per cent of her war funds. The industry thus supported and carried on can not but produce some marked effects upon general economy. Such is especially the case with Japan, because, as will be fully mentioned afterward, in this country nearly all of the mechanical industries which apply modern science and arts found their origin in military industry, or else developed under its influence. In other words, industries in Japan are mostly either the direct or the indirect product of this industry, and even those which had an independent origin could develop only through its help. Hence in Japan, this kind of industry has the greatest influence upon the general industry of the country. Her economy is directly affected by every ebb or flow of such industry. Not only her manufacturing industry, but also her commerce, agriculture, mining, transportation, etc., go hand in hand with it, affecting in no small degree money circulation, prices, wages, and such other conditions of the everyday life of the inhabitants of the country. But that is not all. The advancement of science and arts, the diffusion of education, the protection of laborers-in these matters also, the military industry of Japan has been an important factor. In short, the degree of development of a nation's military industry not only tells the strength of its military preparations, but also 
serves as the indicator of the progress of its general industry and its economic status, as well as the grade of its civilization. So in Japan, the degree of development of this industry is the sign post which shows the degree of her military strength, her wealth, her civilization, and the development of her national economy. 


\section{CHAPTER II}

\section{EFFECTS ON INDUSTRIAL POLICY}

Agriculture had been the principal occupation of the Japanese before the Restoration of Meiji. Next to it came fishery, which was the occupation of the inhabitants of the coasts, while the people of towns and cities were engaged in trade. As for the manufacturing industry, only a few handiworkers were engaged in such work, scattered here and there in the country; and while some home work was found in urban districts, there hardly existed any factories, unless it were small manufactories of certain kinds which were sometimes found necessary to be set up by either the central government or the feudal lords in the construction of castles and forts, the making of weapons and the building of warships, or else in connection with civil engineering, such as building roads, river channels, harbors and canals. Thus, except the handiwork of fine arts, the manufacturing industry in Japan was very much behind other kinds of industries. As already mentioned in the introduction to Part I, the Japanese began to realize the great need for manufacturing modern arms and war vessels at the end of the Tokugawa Shogunate, as the nation came in touch with European nations. This led to the import of foreign machinery as well as the engagement of foreign experts and teachers. Then, factories for military manufactures were started by the use of the new machinery. At that time, there were not more than ten factories of modern style in the Empire, including both the works of the Shogunate Government and those of clans, and as they were all small and insignificant, their influence was hardly felt in general industry. Although, at the beginning of the Meiji Era, these military factories were put upon an entirely new basis for development, the economic state of the country yet allowed them no large operation. But Japan had many civil wars and foreign expeditions. 
After the Restoration, the internal Saga Rebellion occurred, followed by those of Hagi, Jumamoto, and Kagoshima, while externally the Formosan Expedition took place and then the Sino-Japanese War, the North China affair and the RussoJapanese War followed, each after some interval of time. These wars caused the position of the Empire more and more to be elevated and its responsibility to be increased correspondingly, at the same time augmenting the wealth and resources of the country, all of which led to the extension of military preparations, and with it the development of the war material industry, until it reached the present stage of prosperity. And the influence of this growing military industry which has been felt throughout the industrial world of Japan at this time is very great. It is true that this industry and industry in general are not the same in the articleswhich they produce and in point of perfection and finish of those articles, and therefore are not always common in their economical features. But such things as the raw materials and machinery used in the one industry do not differ much from those used in the other. In foreign countries, army and navy stores, such as clothing, bedding and other small articles, and provisions are not different from what people use in their everyday life, except in form; but in Japan, they are very widely different. After the Restoration, Japan adopted the foreign system of military organization and everything connected with it was, at the time, a startling novelty to everybody. Even its name and use were incomprehensible to the mass of the people, so that it was utterly impossible to imitate or manufacture some kinds of war materials. This was owing chiefly to the fact that Japan then had few experts and workmen skilled in mechanical work; besides, most of the machinery and raw materials needed had to be imported from foreign countries. These technical and economical disadvantages obliged her to buy foreign stuffs, beginning with arms and war vessels, and including ordinary army and navy stores, such as clothing and other wearing apparel. But upon reflection, it was seen that all of the materials required could be produced in the country, 
except a few things such as wool, iron and some other minerals, certain kinds of fat, and chemicals. Scarcity of iron ores was no doubt a great hindrance to the development of the military industry, but even this defect could be met with to some extent; if money and skill were turned toward iron mining, there were mines enough in the country that would produce the metal, even if not of the best quality. Under such circumstances, the collection of such raw materials and the manufacture thereof must at once be begun at home, if Japan aspired for independence in weapons and economic benefit. At the same time, laborers as well as engineers must be trained in order to diffuse technical knowledge throughout the nation. Fortunately, the government realized this situation and spent as freely as finances allowed for buying up-to-date tools, machinery and manufactured articles which might serve as models, and engaging skilled engineers and workmen from abroad. At the same time, the authorities encouraged private persons in the line of this class of raw materials to start new works or extend old ones, while the latter contended with all difficulties, hoping to obtain products equal to those produced in foreign countries. The result was that, despite the lateness of the founding of those factories, their organization was completed and talent in the art improved, so that their products were gradually superseding foreign goods in the home market, when there came the wars with China and Russia and completed what had been started. During these wars, neutral powers refused to sell the Japanese certain war materials because they were contraband of war. So those things had to be obtained in the country. This necessity compelled the nation to produce them at any cost, because in belligerent states the ordinary law of economics is not considered. Both the government and people worked hard for the same end and succeeded in producing articles which had never been produced in the country or else had been produced only in insufficient quantities. After the restoration of peace, people continued to work in their particular lines of industry, extending their means and factories, until today iron and nearly 
all the materials used in the military industry have become producible in the country. As to manufactured articles, their quality has been gradually improving, since the materials for military manufactures must be of far better quality than those used for general purposes, and this prevents the shameful inclination to careless and bad production. Moreover, most of the raw materials of the military industry are also useful in general industry, so that the popular demand for similar articles has increased. Besides, while the manufactured articles made as war materials are seldom fit for general use, the tools and machines that manufacture them may for the most part be used for making other kinds of articles wanted by the people at large. Hence the rise of many factories in connection with the manufacture of these latter articles. Furthermore, one industrial work is apt to cause another of a similar kind and so on, and the result was the evolution of all sorts of new industries. But that is not all. Workmen who had been employed and trained in the military industry went to work elsewhere in private factories, or started little works of their own. This has also contributed greatly to the development of popular industries. From what has been stated above, it may be inferred that the influence of the military industry upon the national policy of industry in Japan is great, or greater than what it would have been in other countries, because the peculiar condition of this country since the Restoration has been such as to bring that industry into special relation with general or private industry.

\section{Protection and Encouragement of Industri}

As a means to the protection and encouragement of industry, local governments or self-governing bodies have often granted subsidies to producers of war materials. On the other hand, the central government or military authorities have seldom given subsidies, and yet they have directly and indirectly helped and protected them in many instances. To secure military and economic independence in war, it is important to have at command the necessary raw materials no 
less than the manufactured articles. Since the Restoration, the Japanese Government has pursued the scheme of gaining such independence rapidly, both in point of art and of economy. As the first step to this end, protection and encouragement were extended to industry in order to prepare raw materials for military manufactures. As soon as the system of military industry was put in order after the Restoration, the government issued instructions to the military and naval authorities to the following effect: The authorities should not refuse to use home products for materials required in military and naval industries merely on account of inconvenience or poor appearance even though they be inferior in quality to foreign products, provided it did not lessen the accuracy and strength of the manufactured articles. Home products should be used except when the prices of domestic and foreign articles differ so much that it incurs a great loss to the national finance when they are used in large quantities. In order to direct or educate the producers toward the improvement of industry, the merit and fault of the produced articles should be pointed out, specimens supplied, engineers and workmen dispatched, and advice given kindly. On the other hand, local govern: ments were instructed to encourage new industries and also to protect old ones. But at that time economic conditions not being advanced, very many materials for military manufactures were left unproduced, in spite of the existence of such raw materials in the country. Moreover, the output of iron, which is the most needed material, was but scanty, and iron foundries of modern style were wanting. All this was the ever-present cause of the importing of the greater part of the raw materials used in military industry. Such materials as had been used or known from olden times or such of them as could be utilized with a little improvement were employed as much as possible. They were copper, brass, lead, pig iron, saltpetre, sulphur, coal, petroleum oil, lime, timber, iron and steel wares, hemp, leather, vegetable and animal oils, wax, charcoal, alcohol, paper, etc. Among these articles, many were inferior in quality to, and others cost more than the 
foreign ones, but gradually these points were improved, and the kinds of products were increased, so that imports were gradually decreasing. However, when later the Satsuma Rebellion broke out, what the authorities could obtain in the country was only raw materials, or else crude articles; there were no real manufactured articles produced, except those from private dockyards, and some small hand-made articles. This was no doubt due to the fact that most of the articles made for military purposes were of such special kinds that people in general could not use them, or else their high quality and consequent high prices made them of little demand in the economic condition of that time, and were therefore unmarketable. It was evident, however, that if the general condition of industry and of society improved, there were many articles used in military industry that could be used for general purposes as well, such as tools and instruments, machines, steam, electric and gas apparatus and engines, rivets, nails, electric wire and cable, certain kinds of paints and varnishes, dyestuffs, woolen stuffs, pumps and fire engines, crucibles, cast metal wares, leather goods, wooden wares, etc. These articles, with the exception of certain kinds of machinery, were those that could be made in Japan; but the fact was that they were not made, and were imported to a large amount. So it was time now to protect and encourage the production of manufactured articles, as the case had been with raw materials some years before. To accomplish this, crude or finished materials for arms, ammunition, clothing, etc., used in the said war were mostly ordered from specially appointed individuals or companies at standard fixed prices profitable to them. This amounted to an indirect subsidy, and factories were established in localities where army divisions were garrisoned, for the purpose of manufacturing war materials, and soon became suppliers also for the general market. The factories thus established and remaining to this day laid then the foundations of their present well-to-do positions by selling their products largely to military factories. Industries in such materials as timber specially and largely used in military and 
naval factories and wool for the government woolen cloth factories were started as the result of the earnest encouragement given by the military authorities at that time. Along with the extension of military preparations after the Satsuma Rebellion, industries in this line made some noticeable development. A good many things made remarkable advancement in this period. Among them may be mentioned certain kinds of mineral, vegetable and animal oils, leather goods, chemicals, building materials, thistle nut for bristling woolen fabrics, which had hitherto been large or entirely imported.

At the opening of the Sino-Japanese War, war materials of great variety and amount had to be hastily provided, and those which could not be produced at once in the military factories, or others which could not be imported for want of time or on account of the rules of contraband of war, all had to be made in private factories, the work of which was consequently increased very suddenly. Therefore, the authorities gave every convenience they could to those factories, and, by joint effort with the latter, worked in the direction of the development of these industries, so that all the articles necessary for the war were fully supplied without hindrance. As a result of this, the production of raw materials and manufactured goods in private factories, which had been thus started or enlarged during the war, was not only continued, but extended more and more after the war, keeping pace with the post-bellum restoration and expansion works of the army and the navy and the general improvement of economic conditions. The principal industries newly started during this war were as follows: copper, iron, electricity, gas, castings, crucibles, machinery, ships, clothing, boots and shoes, leather wares, canned goods. Together with the industries in these articles, industries in raw, crude and refined materials connected with them made also remarkable development. All this was due to the fact that during the war efforts were made by the authorities to draw great quantities of supplies from private producers by offering them liberal prices; especially, for those articles which required special encouragement, purchase was made by free 
contract or limited tender; factory houses and land were leased or sold to accommodate the producers; engineers and workmen were advised and taught; and other adequate measures were taken by the government in order to encourage and protect industries. After that, up to the time of the Russo-Japanese War, such big industries as iron manufacturing, shipbuilding, and iron works, which stand in close relation to military industry, together with other industries such as stock farming, timber manufacture, mining, weaving, woolen fabric manufacture, cotton spinning and weaving, tanning, etc., were speedily advanced, and flourished.

As the Russo-Japanese War was fought on a scale many times larger than the war with China, it was natural that arms and ammunition, ships, implements and other war materials were required in immense quantities in that war; and they were made in military and private factories to an unprecedentedly large amount, as there was, just as in the previous war, the necessity of speedy supply and the suspension of importation of contraband of war. This exercised a remarkable influence upon domestic industry. Not only in manufacturing industry, but in agriculture, forestry, mining, and every other line, a very great advancement was made. In fact, the war was a turning point in the history of Japanese industry. After the war, the newly started or developed industries were extended'more than ever, owing, as in the case of the Sino-Jápanese War, to the post-bellum restoration, the expansion of military preparations, etc. Moreover, the government, availing itself of this opportunity to secure independence in war, encouraged the use of domestic articles, which gave them another impetus, and has now resulted in the establishment of Japanese industries on an equal footing with their foreign rivals.

It is difficult to enumerate the diverse industrial works which arose after the war. To these the military and naval authorities extended protection in various ways. The most effective means of protection was to buy their products by free con- tract, or by limited tender, which allows only those persons who are appointed to bid for sale. This latter method, seem- 
ingly not so effective, worked in practice as well as a subsidy, because war materials are sold in great quantities, and comparatively high prices are commanded by them, as there are not so many competitors in this case as there would be otherwise, and, moreover, the amount of demand is constant and the price seldom undergoes any sudden changes. The producers thus stand on a very solid basis. This system may have the evils attached to monopoly; but it was unavoidable as a means of protection for domestic industry, when the economic condition of the country was not advanced. It is still more excusable considering that war materials must be of sound quality and require prompt delivery, and, for that reason, contracts of purchase with inexperienced and less skilled producers who may send coarse articles or make unpardonable delays must be absolutely avoided. Instances may be mentioned here in which protection is being given to industries by the army and navy as begun after the Russo-Japanese War. We may mention the industrial unions of Miyazaki Prefecture, under special agreement with which the army is buying all of what is produced in that district of the wood used for gun stock. Besides, the purchase of rice, barley, vegetables, oxen, etc., as materials for manufacture of provisions is made directly from local industrial unions that they may have as their profit what otherwise would have enriched the brokers, and have also better chances of improving their products. As for the navy, it assisted in establishing the Japan Steel Foundry at Muroran, and extended protection to canning and briquette factories; and, with the cooperation of the army, to zinc refining, manufacture of sheet copper, electric wire and cable industry, iron-pipe industry, etc. All these industries were given advantages of some kind or other-their products were bought, machines lent, experts dispatched, and materials sold to them by the authorities. Some of them had their businesses greatly facilitated by it. Others would never have seen their establishment in Japan as new industries but for this protection. These facts show how effective and beneficent the protective policy of the government has been upon industries. 


\section{Technical Education}

The foregoing section shows how greatly military industry contributed to enhance technical education in Japan. Here we give some concrete instances thereof.

Before the Restoration, when the new light of reform dawned upon the Japanese Army and Navy, foreign teachers were engaged to teach the Japanese in technical arts. The men thus educated, together with those who had been abroad and returned with modern technical knowledge and training, were all intended for the development of military industry.

After the Restoration, the army and the navy were reorganized upon modern systems, and then they both endeavored to further their industries by engaging foreign teachers and sending pupils abroad. At that time, the economic condition and education at large were not yet advanced enough to establish technical schools where the modern mechanical engineering, naval architecture, etc., might be taught. So the military and naval factories were the only sources of industrial knowledge, whence those officers, engineers and workmen who had been educated abroad were despatched or transferred to other factories, government, public and private, as teachers in industrial arts. After the Satsuma Rebellion, with the perfection of the military and naval technical schools, many industrial schools, government, public and private, of grades high and common, were established, and technical education, which had been monopolized by the military departments now came, as a rule, to be given by independent organs of the national education.

Since that time education for technological engineers has been generally given in schools. But the work done by those who had been specially trained at army and navy factories as teachers in the general technical education of the country is not small, though this system of education is going out of practice, as school education is becoming more and more universal. And nevertheless, in the matter of the training of workmen, army and navy factories are still recognized as authorities in industrial circles. We will therefore consider this subject on the following pages: 
There are two special means of training workmen of the factories of the army and the navy. One is the giving of special training at specially provided places of instruction; the other, that of practical training during the men's daily work. In some points, however, the army and the nary factories have each their own features, and it would be more convenient to treat them separately.

\section{In the Army}

The systems of special education given to apprentice or pupil workmen and of supplementary instruction for general workmen were abolished a few years ago, owing to the fact that skilled laborers could easily be obtained, while inexperienced hands could be trained at work with certain precautions, and that, as the factories are mostly situated in large cities, there are not wanting night schools good enough to supply the workmen with necessary knowledge. Today, there are but a few small factories in the more remote parts of the country provided with night schools of their own on a small scale as organs for supplementary training; and so, for the most part, the workmen in military employment are trained in the factories in their working hours.

Since the Restoration, the army factories have produced a startling number of trained workmen. The great majority of them who left with sufficient skill have served in various other factories, or have been engaged in their own works; and thus the good done by the army factories to the industry of Japan is great. At present, as in the past, trained workmen are being continually sent out to general industry, while they are always recruited with new men, who go through the same process of training. A brief statement of the after-careers of those trained workmen is as follows:

Those who have been trained in the manufacture of arms are, according to their special acquirements, employed at a premium in iron and steel foundries, iron works, dockyard building companies, electric companies, and other small industrial works, besides a few who run small factories on their own account. 
Workmen trained in the clothing manufacture in the army can apply their skill in making caps, uniforms, overcoats, underwear, drawers, etc., in similar tailoring works outside. So, if they leave the service by discharge or of their own accord, they readily enough enter other factories or independently become tailors. Besides, as the use of sewing machines has become general of late, some workmen find a way to use them at home in private occupation.

Workmen skilled in leather work usually start for themselves a business of shoemaking, harness-making, etc., or are employed by companies or individuals manufacturing those articles. They are very welcome in the trade.

Those who have been trained in the woolen cloth manufacture are in great demand by woolen cloth factories, spinning companies, etc.

Men who have been trained in the provision department are engaged by canning or baking factories, while some who have skill enough start their own canning works on a small scale, or engage in making cans.

Besides, workmen who have acquired the knowledge of handling engines, boilers, dynamos, motors, etc., can be employed in any factory worked by machinery, and therefore have a larger sphere of employment.

\section{In the Navy}

The system of special training is still pursued. Instruction is given in and out of the factories. The instruction in the factory is given principally within the government factories. The instruction out of the factory is under the control of the cities or towns where the factories are located, the authorities, of course, cooperating with these cities or towns. Both sorts of instruction are showing salutary results.

Instruction in the Factory.- In all naval arsenals, the same system prevails with regard to the instruction of workmen; so the example of the Kure Naval Arsenal, which is the largest of all, will suffice to explain the system.

In the Kure Naval Arsenal, boys numbering three hundred 
who have been graduated from higher elementary schools or been equally educated and are more than fourteen years old are, after an examination, taken on every year as apprentices. After being trained in practice for one year or more, they receive technological education as "sedentary study" pupils for a period of four years. They are obliged to serve for three years after their graduation.

Those workmen who are not apprentice workmen, but are of superior attainments and good demeanor, are picked out and taught in technology, as "sedentary study" pupils.

The "sedentary pupils" who have completed their term of technological study with success or those workmen who have equal attainment may be admitted to the postgraduate course, if they desire it. The period of study is one year.

Private regulations relating to the training of workmen are very minute and thorough for work of this class. They differ but slightly in each of the departments, such as arms manufacture, shipbuilding, etc., as the nature of work is not the same. However worthy they may be, we shall omit enumerating them here for the sake of brevity.

Instruction Out of the Factory.-To give workmen supplementary knowledge, there are industrial supplementary schools or technical supplementary schools, as they are called by either name, established in the offices of the cities or towns where naval arsenals are located. These institutions must necessarily have naval workmen as their pupils, if their original aim is considered, and in fact they have such chiefly; but at the same time they are admitting ordinary pupils from families residing in the place. The school has for its object to put the leisure hours of the workmen to good purposes. It is, on the one hand, to give them industrial knoẉledge and cultivate their moral character, and, on the other, to deprive them of opportunities of giving themselves up to dissipation and thereby vitiating the local good manners, and actually it is obtaining good results in every such city. The teaching staff of the school con-

${ }^{1}$ By sedentary study is meant lessons in technology given along with the practical training. 
sists of teachers of public schools and engineers and inferior officials of the navy. The regulations of these schools being determined in accordance with local customs and conditions of the workmen, the educational work is being thereby conducted satisfactorily.

The above two methods of special training are undoubtedly very effective in producing able workmen. But there are a great many workmen in naval service who, like those in the army, are educated gradually in practice while engaged in their work and become in course of time excellent artisans. They are in great demand in the industrial world, and are contributing much to the enhancement of national industries. Besides, it is customary with the navy, taking advantage of the orders for warships or machines it gives abroad, to send its ablest workmen with the orders to the foreign dockyards or factories and there to let them train themselves in those works. After a few years these men return home with the knowledge gained and in no small degree impart benefit to national industries.

The advantage of all this training of workmen is evident in discipline as well as in skill of work. They are subjected to strict discipline at the factory, and this unconsciously fosters in them the spirit of order and regular habits. Thus they become examples for workmen of other factories.

Of factories of the army, clothing factories and provision factories employ many female hands. Those who are employed in the former generally start private tailoring, when they leave the factories after two or three years of service. Recently these tailoresses are increasing in number, much to the advantage of the community.

\section{Discovery AND InvENTION}

As the direct object of military industry is the manufacture of arms, ammunition, ships, and other war materials, invention and discovery in the same industry are limited to such military articles, and therefore but comparatively few of them have influence upon the general economic world. Especially 
is this true of inventions in arms. And as the manufactured products of military industry can only be used by the army or navy, it is natural that inventions in this realm should have little concern with general industry. But it is different with raw materials. In this field many inventions and discoveries have been made, caused by the presence of the ever-imperative demand of the military industry. Military industry aims at excellence of products without considering gain as in private factories, and time and expense are not spared to accomplish its end. So it makes very rapid progress in the improvement of its manufactures, excelling other manufacturing industries. Improvement in raw materials must keep up with it. Experiments and investigations are necessary, and the result is often an invention or a discovery. Thus, in the number of inventions and discoveries, too, the military industry is greater than other industries. But as has already been said, the influence of these inventions and discoveries upon economic interests in general is limited, and though it is difficult to show this with mathematical precision, as it depends on kinds, time, etc., it is certain that they have smaller range of application than ordinary inventions and discoveries. The following is a summary of inventions which, having been made by military factories or else assisted by them in their completion, are considered to be usable for general economic purposes.

As finished articles in the manufacture of arms and machines, we can enumerate only wireless telegraphs and other apparatus of communication, Miyabara and Kansei-Honbu (Ship Administration Office) boilers, etc.; but in regard to raw materials we find very many important inventions and discoveries peculiar to Japan, for instance, in the manufacture of steel, sheet copper, zinc, pipes, electric wire and cable. These inventions are, after all, the result of secrecy in foreign factories in the same lines of work, or the fruit of effort to produce materials of the best quality.

In the manufacture of ammunition, safe explosives for mines and powder for sporting or hunting guns are products prepared by special Japanese processes and are in great demand by the public. 
In fuel manufacture, there are many devices peculiar to Japan in the making of smokeless coal, coal breakers, etc., and all these can also be used in private enterprises.

Inventions and discoveries in the line of clothing and provision manufacture require little secrecy, unlike those relating to arms, and can be made public in full. But the nature of those works is capable of producing only such inventions as are comparatively trifling, some of them being of too little value to be enumerated. Only those inventions that are applied to manufactures of large quantities, therefore, will be mentioned here.

\section{Clothing Manufacture}

(a) Leather-Preserving Oil.--Formerly several kinds of oil extracted from fat were used to prevent the cracking and hardening of leather and leather articles, but they were not effective, and moreover the articles so oiled had a tendency to mold. To remedy these defects a certain compound of fat oil and mineral and vegetable oils was invented. It proved to be absolutely effective after a few years of experiment.

(b) Steam Pressing Device.--This was devised to smooth out the creases of woolen cloth and generally to effect even smoothing.

(c) Shaping Machine for Upper Shoe Leather.-This is a machine made to quickly give the upper shoe leather a curvature in the shape of the foot.

(d) Shaping Machine for the Hind Part of Shoes.-This is a derice to give the hind part of shoes quickly the roundness of the heel.

The above have all been tried with good results.

\section{Provision Manufacture}

Biscuits baked by fermentation system, air-system canned meat, can strapping, and asphalt varnish for cans are special products or processes of the Provision Department. Especially "cakes of soy extract" are quite a new invention. Of these inventions, the method of can strapping has been adopted by some private factories. 


\section{Woolen Cloth Manufacture}

(a) An invention for extracting the grease of wool from the water in which wool has been washed for utilization in other warp.

(b) As the suds which are used for washing woolen fabrics catch olein oil used in preparing wool, besides containing what had been compounded in the soap, a process was invented to get the oil out of the foul water.

These are from what are known as the inventions of the factories. Besides, there are many inventions made by engineers or workmen of military factories through the experience they had acquired during their long factory life, which have proved of great benefit to the Japanese military industry as well as to the economic interest of the country. Unfortunately there are no statistics with regard to these engineers and workmen who have their patent or other rights registered, but it is a fact that they apply for patents in large numbers. 


\section{CHAPTER III}

\section{EFFECTS ON MANUFACTURING INDUSTRY}

The business of military factories and that of private factories must be conducted differently, as their products differ in kind and quality and the military work generally requires secrecy. Yet the industry of the army and the general industries of a nation can not be completely separated when the needs in time of war and in the development of general industry are taken into consideration. On the contrary, they are ever approaching nearer to each other as the civilization of the world advances. If they be completely separated or their progress unequal, imports will increase, resulting in the outflow of specie. In time of peace, and in time of belligerency, war will be unfavorably affected by the lack of materials in consequence of the stoppage of imports because the communication is more or less interrupted and of the international relations which impose some check upon trade. But if they go on hand in hand, the materials wanting will be found in private factories and, moreover, skilled workmen of one can meet the urgent demand of the other. For these reasons, the development of general industry must be encouraged if military industry is to be made efficient. The kinds and the progress of the manufacturing industries of a country depend on its natural condition, the wealth and purchasing power of its people, its trade, politics, etc.; and so it is difficult to procure from the private industries just for military industry raw materials, tools, machines, workmen that are suited to its requirement. For instance, when the economic condition of a country is yet in its infancy, the supplying of the tools, instruments, machines, etc., necessary for military industry is out of the question, for we can not expect the mechanical industry of the country to be so developed and ready, owing to the fact that the demand for these articles is scarce in gen- 
eral, and that there is little occasion to export them. As regards iron, which is the most essential material for military industry, it is a matter of course that iron foundries are not to be found when the general demand for iron is but small. But the national industry must be developed, and to do this it must be led to adapt itself to the circumstances of the country. At the same time that the economic condition of the nation is improved, a definite industrial policy must be established to suit the state of the country and the needs of the age. This has been the course taken by the Japanese Government since the Restoration, and the advancement of the national manufacturing industry is the result. Japan from the military standpoint had in the past felt the necessity of rapidly promoting private industries, and therefore the progress of these industries is in a great measure identical with that of military affairs. In Japan, military progress was more rapid than economic progress. If her manufacturing industry had been left to itself to advance, its progress would not have been so rapid as it was. But the circumstances did not admit of its gradual progress, but forced it to advance by leaps and bounds. It is not to be doubted that a quicker time even by decades has been made by industrial progress in Japan through the constant guidance and support of the military industry, which has always been comparatively more advanced. The wars and the extension of military preparations were practically the most timely industrial policy to stimulate the manufacturing industry of Japan to its present day achievement.

The influence of military industry upon private industries has already been stated in the preceding chapter. But its range was limited to factory industries, and did not touch the spheres of domestic industries and manual industries, and even in the former no precise details of the influehce were given. Hence the presentation in this chapter, beginning with the second section, of the influence of military industry upon industries in general, divided into three parts, factory industry, domestic industry and manual industry, to each of which a section will be given. 


\section{FACTORY INDUSTRY}

\section{Advantages Derived by General Factory Industry}

We can not exaggerate too much the past influence of military industry upon the economic world of Japan. It was wide and far reaching. But it was especially remarkable in the manufacturing industry. This influence had the positive tendency of promoting the industry and little impeded its conduct or development. Advantages given to general industry by military authorities lay chiefly in the encouragement of enterprise, convenience given to management, advice in industrial arts, ordering and purchasing products, etc., which, as already seen in the foregoing chapter, was effectual in bringing on the general development of private industries. We shall now state in a more concrete manner the influence of military industry exerted upon more important branches of industry, such as arms manufacture, shipbuilding, the manufacture of iron and other materials, etc.

Arms Manufacture.- The private industry most open to the influence of arms manufacture is the manufacture of materials necessary to the production of arms. As arms must be most carefully and strongly made, the greatest attention is paid to the selection of materials. Domestic materials essential to the manufacture of arms are replaced by materials imported from foreign countries if found to be of inferior quality in even the slightest degree. Imports, therefore, form a prominent part in arms manufacture. This is one great drawback to the independence of national arms and also causes an outflow of specie, which is a most deplorable condition for a country. However skilful may be the accomplishment of military and naval factories, the military, financial and economic objects of a country are unattainable with regard to the management of the factories, unless the private industries are developed which produce for them the materials to work with. The Japanese Government saw this need and gave assistance in establishing and developing private factories which had for their chief object the supplying of the necessary mate- 
rials to the government factories. As has often been stated, the government took various measures to this end, "and especially laid stress upon the manufacture of metallic materials. But as the management of steel founding by private companies is somewhat difficult, the military authorities initiated the work in the Osaka Arsenal, while the navy started one in the Kure Naval Arsenal, and set a live example before the people.

After the Russo-Japanese War, the demand for materials for arms greatly increased in consequence of the expansion of military forces as a post-bellum measure. Finished arms, too, became of such great demand that the arsenal often found it difficult to keep up with it. In the face of these circumstances, there was not even one private iron foundry or arms manufactory in the whole empire. In Europe and America, war implements, whether arms or not, are manufactured at private factories at the same time as they are manufactured at government factories; these factories, governmental and private, work together, and acting in common, not only sustain independence in war implements, but try to get what profit would accrue to their national wealth by manufacturing foreign orders. These private factories are showing even better results than governmental ones, contributing greatly to the improvement of arms and other war implements. The establishment in this country of a large private company, as in other manufacturing industries and shipbuilding, where at the same time steel and arms manufacture could be conducted, was felt necessary from the military point of view and from the interest of national economy. Thus, following the example of foreign countries, the Japan Steel IVorks was established in the 4oth year of Meiji (1907) through the assistance of the army and navy departments; and it began its work in January, 44 Meiji (I9II). It is capitalized at 15,000,000 yen, and has ten workshops, viz., finishing, rough finishing, tempering, forging, casting, pattern and mold making, blacksmithy, laboratory, electric power house and boiler room, and gas generating furnace. The articles made by the company are as follows: Gun barrels up to 
I4-inch calibre and gun carriages for army and navy, ammunition hoists, torpedo tubes, steel castings up to roo tons, steel forgings up to 80 tons, iron castings up to Ioo tons, cast-iron projectiles, articles of gun metal and brass up to 30 tons, submerged torpedo tubes, phosphorus for fish torpedoes, bronze wares, materials for gun carriages, materials for fuses, metal fittings for ships, propeller cocks and valves, condensers, hangers and bearings, cast steel, cast iron, gun metal, machines of all kinds for factories, etc. At present, the company not only furnishes the Japanese Army and Navy with necessaries, but also exports war materials to neighboring and other countries. It is the only private establishment in the country which manufactures arms, and it owes its origin and existence entirely to the military industry.

Moreover, the following are the somewhat large factories which, either as their sole business or as a part but main object, produce materials and tools and machines for the manufacture of arms:

The Sumitomo Sheet Copper Manufactory (Osaka), The Tokyo Balance Manufactory (Tokyo), The Tokyo Rope Co., Ltd. (Tokyo), The Tokyo Spring Manufactory (Tokyo), The Tobata Casting Co., Ltd. (Fukuoka), The Osaka Zinc Co., Ltd. (Osaka), The Shinagawa White Brick Co., Ltd. (Tokyo), The Nippon Ceramic Co., Ltd. (Tokyo), The Osaka Electrocopper Refining Co., Ltd. (Osaka), The Yamanaka Copper Works (Osaka), The Yokkaichi Oil Factory (Ise), The Settsu Oil Manufacturing Co., Ltd. (Osaka), The Yokohama Wire Manufacturing Co., Ltd. (Kanagawa), The Sumitomo Wire Manufactory (Osaka), The Fujikura Wire Co., Ltd. (Tokyo), The United Electric and Wire Co., Ltd. (Tokyo), The Nippon Wire Co., Ltd. (Tokyo), The Oriental File Co. (Osaka), The Tanaka File Manufactory (Osaka), The Seike File Manufactory (Hiroshima), The Meiji Rubber Factory (Tokyo), The Mitado Rubber Manufacturing Co. (Partnership) (Tokyo), The Nippon Rubber Co., Ltd. (Tokyo), The Kawasaki Dockyard, Ltd.(Hyogo), The Nishimura Machine Factory (Tokyo), the Kanezaka Factory (Tokyo), the Nagase Iron Works 
(Saitama), The Nitta Belt Manufactory (Osaka), The Bando Cotton-belt Co. (Hyogo), The Izumi Lead Pipe Manufactory (Osaka), The Okumura Electric Co. (Kyoto), the Kanda Rivet Manufactory (Tokyo), The Yamamoto Screw Rivet Manufactory (Tokyo), The Ota Casting Mill (Tokyo), the Nagoya Factory (Saitama), The Sekiguchi Manufactory (Saitama).

We can almost say that the abore-mentioned companies were established and supported solely by military industry, if we examine into the motive of their foundation, their history, their market and the amount of their manufacture. They stand as leading powers in the industrial world of Japan, having handsome capitals and numerous workmen; but, if once the relation between these companies and military factories comes to an end, most of them must be dissolved, or else cut down their plans and exist under adverse conditions, so great is the influence of the military industry of arms upon industries in general.

Shipbuilding.-The number of shipbuilding yards built after the Restoration of Meiji totals over two hundred, and the eldest of those which are run on a large scale are the Mitsubishi Dockyard at Nagasaki and the Kawasaki Dockyard at Kobe. These two yards were established in the days of the Tokugawa Shogunate, the former then being the navy yard of the feudal government and the latter the iron works of the feudal clan of Kanagawa. It is thus obvious that these dockyards owe their origin to military manufactories. Among the rest which were under the control of the feudal government were the Ishikawa-Jima, the Uraga, and the Yokosuka Dockyard's, and the Yokohama Iron Works. All of these establishments were transferred to the charge of the Heibusho (Department of Military Affairs) and the Kobusho (Department of Industry) after the Restoration. For more than ten years dating from the Restoration, the shipbuilding industry was entirely left to the Imperial Government; this is attributable to the fact that the knowledge of maritime affairs at that time was very limited among the people and that this kind of industry could not sufficiently arouse their interest 
as it actually does now. In about the I6th or the 17 th year of Meiji (I883 or I884), with the progress of marine transportation, the ships requiring repairs increased so greatly that many persons gradually decided to launch forth in this undertaking. Thereupon the government saw no further necessity of monopolizing the business, and with a view to promoting the shipbuilding industry among the people, it turned over the two yards at Hyogo (or Kobé) and Nagasaki to bidders in I7 Meiji (I884), and again the Department of the Navy disposed of the shipbuilding yards nat Uraga and Ishikawa-Jima with the same purpose in view. This marked a new epoch in shipbuilding in this country, which was no longer the monopoly of the government. Yet shipbuilding of these days was only in its transitional stage, and the government had to give unstinted support to the shipbuilders, and in fact no efforts were spared on the part of the government in enhancing the progress of the new national enterprise. In this way the people were able to build in the 2oth year of Meiji (I887) at the Ishikawa-Jima yard the warship Chokai with a displacement tonnage of 614. This was the beginning of the construction of an iron vessel by the same company and of building a warship by the people.

Since then, year after year, shipbuilding companies and ship-repairing works have increased, and the progress in the shipbuilding industry of the country has become more and more apparent. As to the art of ship construction, no remarkable strides were made by private companies outside of those already mentioned, except a very few decidedly independent of government support. The majority of the ship building companies were able to keep on their work only by the help of the navy yards or private first-rate companies in the country.

As a result of the Sino-Japanese War, which raised the prestige of the nation, there came a boom to the shipbuilding industry of the country, and a number of shipbuilding and dock companies sprang up simultaneously, presenting a unique spectacle in the history of Japanese ship construction. This 
noteworthy increase of shipbuilding companies was due in a large measure to promulgation of the Shipbuilding and Navigation Encouragement Law, which the government passed in consideration of the experiences undergone in the Sino-Japanese War and the subsequent economic development.

Striking developments had also been made in the construction of warships and mercantile vessels during and after the Russo-Japanese War, and the number of dockyards and shiprepairing works in the country reaches now over two hundred. With exception of only a few, these shipbuilding companies have not attained their present prosperity by the direct influence of military industry; yet this much is certain, that the shipbuilding industry in general has run on the same course of progress with that of the navy, and that the two recent wars fought with China and Russia have accelerated its progress. The relation between the general shipbuilding industry and the naval construction works after these wars was very close, and it goes without saying that the majority of the shipbuilding companies have been indirectly influenced by the military industry. Space does not permit an attempt at a detailed account of all the influences that are directly related with the naval industry, and only a brief account of some of the striking instances of the latest occurrence will be ventured.

It has been previously stated that remarkable progress was attained by the navy in the construction of warships, with the Russo-Japanese War marking a new epoch. But it must be also understood that equal progress favored the national industry of shipbuilding. Especially shipbuilding companies like Mitsubishi and Kawasaki were splendidly equipped almost to the point of perfection, and even the smaller ones, such as the Osaka Iron Works and the Uraga Dock Company, gained more or less experience and have become capable of constructing cruisers or torpedo-boat destroyers or ships of similar importance. Then the Russo-Japanese War took place and made busier the work of warship construction, and the power of the navy alone could not meet all the greater demand. The above-mentioned four private companies were then 
formed to assist the navy. They were entrusted with the task of building torpedo-boat destroyers, which numbered in all fourteen. This was the beginning of the navy ordering the construction of modern warships from private companies.

These warships were successfully completed, and then the Kawasaki Dockyard accepted an order to construct the dispatch boat Yodo and the second-class cruiser Hirado, which were launched in due course of time. The Mitsubishi then built the large torpedo-boat destroyer Yamakaze, the dispatch boat Mogami, and the second-class cruiser Yahagi. Meantime the Kawasaki Dockyard supplied the chief machines to be fixed in the second-class cruiser Chikuma and the battleship Kawachi, which were built at the Sasebo and the Yokosuka Arsenals, respectively, while the Mitsubishi took up the work of providing the large torpedo-boat destroyer Umikaze, built at the Maizuru Arsenal, with the chief machines to be used in its construction." In this way the private industry of constructive warships has made rapid development side by side with that of constructing merchantmen.

The completion of the productive facilities of the private companies has of late enabled the Mitsubishi and the Kawasaki to each build a battle cruiser of the type of the Kongo recently built in England, the launching of each warship having taken place toward the end of 3 Taicho (1914).

The experiences acquired in building such dreadnoughts and armored warships of gigantic size can easily be applied to the construction of merchantmen; needless to say, the shipbuilders of this country have in this way utilized their experience obtained in one for the perfection of the other branch of the shipbuilding industry.

Keeping pace with the progress of the warship-building industry, the manufacturing of various materials for the use of warship-building has made great advancement; the steel plates which are chiefly required, steel pipes, copper pipes, brass pipes, and all sorts of copper and brass materials for warships have come to be largely supplied by domestic manufacturers. 
The materials for the making of the ship engines also are produced largely by the Japanese now that the general private industry of the country has advanced, and only patented articles and special machines for the making of engines, that can not be procured at home, have to be imported. As to the rest, all that are employed in shipbuilding are produced in this country as much as possible. The following enumerates the chief materials, indicating their places of production:

\begin{tabular}{|c|c|c|}
\hline & Manufacturers & Materials \\
\hline Steel plates. & Japanese & Partly foreign \\
\hline Steel pipes. & " & Foreign \\
\hline Copper plates. & “ & Japanese \\
\hline Copper pipes $\ldots \ldots \ldots \ldots \ldots \ldots$ & “ & \\
\hline Condenser pipes $\ldots \ldots \ldots \ldots \ldots$ & “ & Partly foreign \\
\hline Castings & “ & “" \\
\hline Forged metals. . & “ & \\
\hline
\end{tabular}

The articles listed above were formerly all imported, but the recent development of the domestic industry has greatly diminished their importation, with the consequence that Japan has saved an enormous amount of outflowing expenditures. These instances show conclusively how great the influence of military industry has been upon general industry.

Iron Manufacture.-Iron has been produced in Japan from olden times, and the producing area extends over one-third of the entire area of the Empire. The iron ores produced include magnetite, hematite, limonite, xanthosiderite and magnetic sand, but only the last named has been chiefly used from early days, and from it they made swords and iron wares. After the Meiji Restoration mechanical engineering made steady progress, and iron has come to be in great demand. But the mining industry and iron manufacturing and refining work were yet very inactive, and only at the Kamaishi mine and the Sennin mine of Iwate Prefecture a limited amount of iron oreswere dug out and refined about the time of the Restoration. But the lack of skill in the work, together with the small demand for iron at that time, forced the immediate closing of operations, the one at Kamaishi having been closed in the I6th year of Meiji (I883) and the other at Sennin not long 
after its inauguration. The old mode of iron manufacturing was no more than the refining of magnetic sand by the use of charcoal. In about the 2oth year of Meiji (I887), however, with the gradual progress of military and naval industry, Japan had to import various kinds of iron and steel materials to meet the increasing demand. The government, considering, on the other hand, the military importance as well as the importance of preventing foreign imports, reopened the iron manufacturing work at the Kamaishi mine sometime about 30 Meiji ( 1887 ) by leasing the property to private enterprise.

Upon the close of the Sino-Japanese War the government felt the importance of iron manufacturing even more keenly, and in the 28 th year of Meiji (I 895) it prompted some capitalists among the people to reopen the old works at Sennin, and in the 34th year of Meiji (I9OI) iron refining was started at this place. Almost at the same time a pig-iron refinery was built at Kuriki, Iwate Prefecture, and from these sources the government was able to obtain some amount of iron for the military and naval factories.

Before this time, as a result of the Sino-Japanese War, the government was awakened to the necessity of independence in arms, and, together with the object of consolidating the foundation of the general manufacturing industry, it'was induced to establish a model factory for iron manufacturing at its own expense. In March, 29 Meiji (I 896), the government promulgated a law pertaining to the iron foundry, which it declared under the direct control of the Department of Agriculture and Commerce; and in February of the next year it was notified that an iron foundry would be built at Hachimanmure, Fukuoka Prefecture, where, upon its nearing completion, it began the manufacture of pig iron in February, 34 Meiji (I90I). As the work of construction further advanced, other works in iron manufacturing were put into operation; then the outbreak of the Russo-Japanese War prompted several more new undertakings to be added. But with all the accommodations introduced, the amount of steel produced at the foundry was not more than 90,00o tons a year. Compar- 
ing this with the average amount of steel imported yearly during the three years preceding the late war (some 230,000 tons, valued at over 20,000,000 yen), Japan could never be satisfied with the result - the production falling far short of the demand of the country. Moreover, the demand for iron after the late war tended to increase with the development of the industry, and it now became necessary that the foundry be enlarged to meet this demand, so that a new plan was devised to bring out annually I80,000 tons of steel, or twice the original amount. This plan was put into execution in the 39th year of Meiji (I906) and was completed in the 42d year of Meiji (I909). But when this extension was completed, it was found that the public demand for iron had increased considerably, and that without another expansion it would become totally impossible to meet the general requirements. Consequently in the $44^{\text {th }}$ year of Meiji (I9II) the government set about to further enlarge iron manufacturing on a scheme of six years' standing, by which Japan can obtain fully 300,000 tons of steel a year.

As seen by the facts mentioned above, the establishment of the iron foundry at Hachiman was in the main necessitated by war preparations. Not long after the opening of the foundry, the Russo-Japanese War broke out, and with the increased manufacture of arms it was necessary to enlarge the foundry to meet the demand for iron, which as a matter of course increased greatly. Then came a third expansion. It had to be effected in order to make up the loss of arms by the war and to meet the greater requirement for munitions consequent upon the military expansion. Such being the case, it will be easily understood that the iron foundry at Hachiman has been closely related to the manufacturing of arms from its very beginning.

Again, no one can doubt that military industry has been instrumental in the promotion of the technical ability of the foundry. It affords the foundry opportunities to add to its skill in producing special steel by taking orders from the army to manufacture barrels of small arms and steel projectiles. In like manner the demand for thick steel plates by the navy 
has prompted the acquisition by the foundry engineers and workmen of greater efficiency in turning them out.

The iron foundry at Hachiman has now the following accommodations:

Two coal washing shops, I 50 solvay coke ovens, I20 copper coke ovens, I sulphuric acid factory, i ammonium sulphate factory, I pitch factory, I fire brick factory, I lime factory, I slag brick factory, 4 cupolas, I blower building, I pig-iron mixing oven, I 2 Siemens-Martin converters, 2 Bessemer converters, I crucible steel factory, I copper refining factory, 2 roller mills (for billet of broom), I rail factory, I large size roller mill (for various sections of bar), I iron refining factory, I medium size roller mill (for various sections of bar), 2 small size roller mills, I wire manufacturing factory, I thick plate factory, I thin plate factory, I open hearth steel factory, I corrugated sheet iron factory, I tire rolling factory, i factory for manufacturing steel projectiles, I bolt factory, I lathing shop, I factory for repairing electric work, I workshop for repairs, I boiler making factory, I smithy, I casting mill, I laboratory, I house for the examination of manufactures. The motive power by which the above factories and apparatus are put into operation is generated by steam, electricity, or hydraulic pressure. The steam boilers in the premises number 207 , and the engines and motors number 122, the entire motive power produced by these means amounting to 48,900 horse power. Of the entire motive power some 4,700 horse power is produced by hydraulic pressure and about 3,015 by electricity. Lastly, the workmen engaged number nearly 9,000 in all.

The chief manufactures are materials or half-made articles for military and naval industry, some being disposed of for the benefit of the people. Formerly the foundry accepted orders from foreign countries to make military weapons, but now the demand for iron at home exceeding by far the whole amount produced has become too great to accept foreign orders.

In short, the military industry has been instrumental in the establishment of the iron foundry and in the birth of new min- 
ing and refining works in this country, thus initiating effective methods for utilizing national wealth to the best advantage, and promoting the interests of those undertakings.

Clothing and Provision Industry.-The work of the Senju Woolen Cloth Factory is comparatively the oldest in its origin of the industrial factory in Japan. The factory was established when the country was yet in its infantile stage as regards national industry. It early installed motors, spinning machines and weaving machines, and acted as a pioneer in the mechanical industry of the country. Besides, as it had no need of secrecy like an arms manufactory, it was open to public inspection; the factories for manufacturing woolen cloths, for cotton spinning and manufacturing, and for general weaving industry, aswell as any other factories run by power generating machines, sought for hints and suggestions in this factory as to technical points, the purchase of goods, the employment of artisans, the keeping of orders in a factory, the storage of goods, the packing and spinning of these manufactured articles, etc. The woolen cloth factory was itself confident of its model organization and willingly offered various facilities to private companies, trying assiduously to diffuse the knowledge of factory industry among the people. The companies built in Tokyo and the neighborhood some years later for the manufacture of woolen or cotton cloth largely followed the system of the Senju factory. This is especially true of the woolen manufacturing companies, which, including even those of the latest establishment, have chiefly adopted its managerial and technical methods. Among such companies are the Tokyo Woolen Cloth Manufacturing Company, the Tokyo Woolen Textile Company, the Kakogawa Japan Woolen Textile Company, and the Goto Woolen Textile Company. Moreover, the Senju factory has contributed a great deal toward the advancement of the manufacturing industry of those materials that are used at the factory. Palm oil, camphor oil and machine oil (gasoline, valve oil and engine oil, inclusive) which are used in large quantities at the factory, are among those things the production of which has been im- 
mensely influenced by the existence of the factory. The presence of the factory has equally influenced the industry of bringing forth worked wool, artificial wool and dyestuffs.

The clothing industry under the supervision of the Clothing Department and its branches (governmental), however, has produced little effect upon the same line of industry pursued in factories carried on by the people; the reason is that the work of clothes and shoe making has been mostly conducted at home and not at factories. Only the work of such companies as essentially aim at the making of military clothing, including the clothing factory of the Okura-gumi and its shoe department, the Sakura-gumi Shoe Manufactory, and the Tokyo Shoe Manufacturing Company, has been affected since the establishment of factories by the government, which have come to manufacture the bulk of similar articles. As regards the materials of the clothing manufacturing industry, the influence of the governmental works has been manifest; besides being supplied by the Senju Woolen Cloth Factory (governmental), the government has had to purchase the most important woolen materials largely from private companies. Hemp cloths have been purchased from private hemp manufacturing companies, and cotton cloths from cotton textile companies. Leather used for shoe manufacturing and other purposes was formerly imported from abroad, but in recent years the bulk has been provided by domestic manufacturers. And the dyeing of cotton and hemp cloths is entirely in the hands of private factories. Altogether, the greatness of demand and the skill of work required in these materials have made this line of factory industry develop considerably.

Speaking of the provision industry, we must add that its materials are more largely obtained from agricultural or stockfarming sources than supplied by industrial companies; consequently this line of government industry would have but slight effect upon factory undertakings. Only the government's canning factory, the equipment of which is well-nigh perfect and which is looked upon as the model factory of the kind in Japan, is frequented by manufacturers in the same 
line, who are greatly benefited by their examination of the manufacture. The manufacture of bread is largely carried on by both the armyand the navy, but the specialty of their products is not conforming to the general taste, so that their bakery work produces little or no effect upon the national industry of bread making. The production of wheat flour, which forms the chief material in bread making, produces more or less effect upon the flour industry among the people. Rice milling, which is conducted on a large scale by the government, sets a good example to the people, who are introducing many innovations in their methods of cleaning rice.

\section{Loss Suffered by General Factory Industry}

In the preceding pages a general statement has been made as to the influences caused by military industry upon factory undertakings. But the influences referred to were of such a nature that their presence and power are constantly desirable, and what unfavorable effects military industry has given to factory industry in general remains to be explained. The use and users of military manufactures differ from those of general industrial products, and very seldom, if ever, do the military manufactures appear in the market; consequently these manufactures would not compete with other market goods, or impair or destroy the undertakings of the people. 'The trouble is that, inasmuch as the amount of materials used and the number of workmen engaged in military industry are enormous, possibly some materials which are also used in general industry will rise in their market prices and the wages of the workmen will be raised at the same time. These will, it is feared, culminate in the depression of general industrial undertakings. But those industrial companies which aim at the production of articles used in military industry suffer very little from the rise of market prices and of the wages of workmen, because their manufactures will be readily purchased by the government and the loss to be otherwise incurred will be fully compensated. On the contrary, the industrial companies which are in no way connected with military industry 
must take the natural consequences resultant from the above circumstances. Especially, the extent of damages suffered by such companies at the places where there are large military factories is amazingly great, though exception is made in those in large cities like Tokyo and Osaka. The fact is best illustrated by like companies built near the naval ports.

There are, of course, some articles and materials which were or are manufactured for military purposes and which have been also disposed of for the benefit of the people. For convenience, the manufacture of such articles has been undertaken by the government as a by-work; the articles thus manufactured have been distributed to government departments and public bodies, or widely among the people. Those that come under the former category are bronze statues, iron water pipes, parts for heavy machines, horseshoes, etc., and among the latter are included short guns, gunpowder for shooting, mining explosives, dynamite, sodas, weak acids, artificial wool, felt, etc. These articles mainly include those that are not manufactured by the people, owing to the lack of necessary accommodations, those which as explosives are prohibited from manufacture by the people by the national law, and by-products of military industry. Of these things which are used by the people, the demand for explosives is exceedingly great, and not a small amount is annually imported. And there is every prospect of development in this line of industry, if it is only transferred to. the hands of the people. To monopolize this kind of industry on the mere ground of preserving public peace is indisputably disadvantageous to the progress of national industry and to. the economic policy of a nation.

At the time of initiation the manufacture of woolen cloth was taken up by the army, in consideration of its military importance and the limited extent of progress made by national industry. The services of the woolen cloth factory (Senju) rendered to our industrial world ever since must not be ignored; yet it remains a question deserving careful study whether such an industry should ever be conducted under government man- 
agement, especially when industrial conditions at large have so much improved as today. In fact we can not say today that the existence of the factory may not become an impediment to the progress of the national industry of manufacturing woolen cloth.

Since the industry of manufacturing clothing and provisions was assumed by the army, a loss has been suffered by the clothing factories, canning factories, and bread-making establishments, which had hitherto aimed at the production of such things, some of the factories having been compelled to close their business. This can be regarded as one phase of the baneful influences exercised over the national enterprises by the domination of military industry.

\section{Domestic Industry}

In order that military industry may have its influence upon domestic industry, it is essential that its work be suitable to the latter. The making of arms, ammunition, mechanical implements and war vessels can never adapt itself to domestic industry, and naturally it will produce little effect upon the work at home. On the contrary, the clothing industry has close relations with domestic industry. From ancient times the clothing industry in Japan has mainly relied upon handicraft and domestic labor. After the Meiji Restoration, when the army and the navy adopted the European system of organization, a change took place in the clothing of soldiers and sailors, who have come to wear European uniforms and military shoes. Hence, these uniforms and shoes were made by the army and the navy, each of which, among its divisions, had a certain number of foremen and artisans for the purpose. But the uniforms and shoes thus made were very small in number, and the bulk of the supply was prepared by professional tailors, shoemakers, and leather dealers among the people. And this work was done at home. At various places where garrisons and naval stations were located, many clothing makers lived here and there and carried on theirwork. Consequently, in the early years of Meiji, when few people wore 
European clothes and shoes, the number of tailors and shoemakers for the army and the navy was far greater than that of ordinary tailors and shoemakers. Upon the expansion of the army and navy later on, soldiers and sailors greatly increased numerically and military tailors and shoemakers as well. By that time some of the uniforms and shoes for military purposes were made at the factories of private companies, but they were not many. The greater part was still made at home; and for these reasons domestic industry exerted a great influence over the localities where military or naval stations were situated. As a result of the Sino-Japanese and the Russo-Japanese Wars, especially, the number of tailors and shoemakers increased wonderfully, adding more to the prosperity of this kind of domestic industry and causing it to take an important position in the economy of the country. But in the 35th year of Meiji (I9O2) a factory for manufacturing shoes was built in Tokyo, and here military shoes were manufactured. Shortly afterward the cutting of cloth for military uniforms was started by the government and contracts were given for making up the cut cloths to tailors among the people. Again in the 37 th year of Meiji (1904) the government initiated the sewing of the important parts of military clothing, and this government work threatened to deal a serious blow to tailors and shoemakers among the people, when about this time the Russo-Japanese War broke out and these traders received large orders from the government to make military clothing, so that they could continue their work, though with much difficulty. The war ended, the work of the Clothing Department (governmental) was enlarged, and the making of clothing has come to be conducted on a greater scale. This brought about a decline in the domestic industry, which had been most successful in making clothes and shoes. Many tailors and shoemakers closed their business for other profitable callings and some became workmen of the Clothing Department. In this way the progress of the clothing industry carried on by the army has exercised a deadly influence over domestic industry. But even today the less important articles 
of military clothing, as shown in the following table of classification, are made by the people, from their own materials or from materials furnished by the government. The articles of clothing for the use of the navy are numerically far inferior to those of the army, but the manufacture is altogether in the hands of the people, and not a few are engaged in this line of work as their principal occupation or a subsidiary one.

The provision industry of the government has had little to do with domestic industry. It only gives some assistance to the domestic industry in such kinds of products as paper bags, wrappers and packing materials used for manufactured goods, as the making of these things are entrusted to the people. The manufacture of military clothing and that of provisions was formerly conducted by people at various places throughout the country where garrisons are located. But since the transference of these industries to the army, the works have been concentrated in Tokyo, Osaka and Hiroshima, under the factory system, and as the result of their absorption of a large working population, damage has been done to some of the different kinds of domestic industry carried on in these localities.

Table Showing Military Clothing as Supplied by Government or PEOPLE

\begin{tabular}{|c|c|c|c|}
\hline $\begin{array}{l}\text { Supplied by the } \\
\text { Government }\end{array}$ & $\begin{array}{l}\text { Supplied by the } \\
\text { People }\end{array}$ & $\begin{array}{c}\text { Supplied by the } \\
\text { Government }\end{array}$ & $\begin{array}{l}\text { Supplied by the } \\
\text { People }\end{array}$ \\
\hline $\begin{array}{l}\text { Caps (a greater } \\
\text { part) }\end{array}$ & Caps (part) & & $\begin{array}{l}\text { Summer under- } \\
\text { shirts and } \\
\text { drawers }\end{array}$ \\
\hline $\begin{array}{l}\text { Winter uniforms } \\
\text { Summer uniforms }\end{array}$ & $\begin{array}{l}\cdots \\
\cdots\end{array}$ & $\begin{array}{l}\text { Lace boots (a } \\
\text { greater part) }\end{array}$ & $\begin{array}{c}\text { Lace boots (part) } \\
\ldots .\end{array}$ \\
\hline $\begin{array}{l}\text { Overcoats } \\
\text { Rain coats }\end{array}$ & $\begin{array}{c}\cdots \\
\cdots \\
\text { Shoulder strans }\end{array}$ & Puttees & Leather gaiters \\
\hline $\begin{array}{l}\text { Shoulder straps } \\
\text { (part) }\end{array}$ & $\begin{array}{l}\text { Shoulder straps (a } \\
\text { greater part) }\end{array}$ & $\ldots$ & Socks \\
\hline $\begin{array}{l}\text { Collar patches } \\
\text { (part) }\end{array}$ & $\begin{array}{l}\text { Collar patches (a } \\
\text { greater part) }\end{array}$ & $\ldots$ & Spurs \\
\hline$\ldots$ & Rain coats & $\ldots$ & Gloves \\
\hline & $\begin{array}{l}\text { Winter working } \\
\text { suits }\end{array}$ & $\ldots$ & \\
\hline$\ldots$ & $\begin{array}{l}\text { Working caps } \\
\text { Working suits }\end{array}$ & $\cdots$ & $\begin{array}{l}\text { Aprons } \\
\text { Leather aprons }\end{array}$ \\
\hline & $\begin{array}{l}\text { Winter undershirts } \\
\text { and drawers }\end{array}$ & $\cdots$ & Pantaloons \\
\hline
\end{tabular}


Table Showing Military Clothing as Supplied by Government or PEOPLE-Continued

\begin{tabular}{|c|c|c|c|}
\hline $\begin{array}{l}\text { Supplied by the } \\
\text { Government }\end{array}$ & $\begin{array}{l}\text { Supplied by the } \\
\text { Pcople }\end{array}$ & $\begin{array}{l}\text { Supplied by the } \\
\text { Government }\end{array}$ & $\begin{array}{l}\text { Supplied by the } \\
\text { People }\end{array}$ \\
\hline 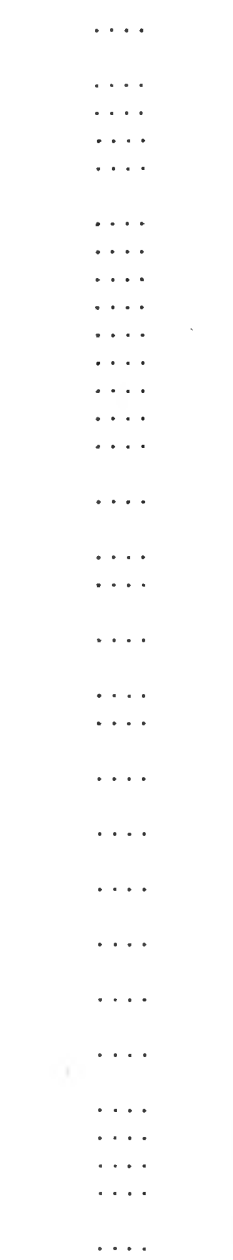 & $\begin{array}{l}\text { Gymnastic caps } \\
\text { Gymnastic jackets } \\
\text { Gymnastic trousers } \\
\text { Gymnastic waist- } \\
\text { bands } \\
\text { Fencing jackets } \\
\text { Fencing trousers } \\
\text { Fencing waistbands } \\
\text { Pocket ledgers } \\
\text { Officers' knapsacks } \\
\text { Knapsacks } \\
\text { Bags } \\
\text { Haversacks } \\
\text { Leather haver- } \\
\text { sacks } \\
\text { Quilts and mat- } \\
\text { tresses, large } \\
\text { Bed sheets } \\
\text { Pillows and pil- } \\
\text { low slips } \\
\text { Pillows and their } \\
\text { covers, large } \\
\text { Mosquito nets } \\
\text { Mosquito nets, } \\
\text { large } \\
\text { Unlined garments } \\
\text { for patients } \\
\text { Lined garments } \\
\text { for patients } \\
\text { Wadded garments } \\
\text { for patients } \\
\text { Shirts } \\
\text { Belts } \\
\text { Garments for luna- } \\
\text { tic patients } \\
\text { Caps for patients } \\
\text { Mufflers } \\
\text { Woolen shoes } \\
\text { Wadded livery } \\
\text { coats } \\
\text { Wadded caps } \\
\text { Wart }\end{array}$ & 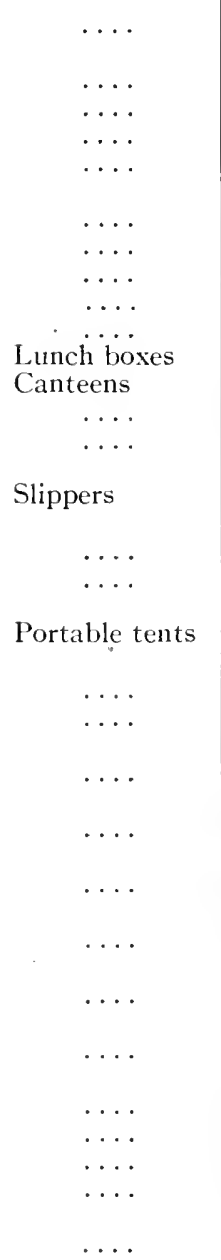 & $\begin{array}{l}\text { Sets for caring for } \\
\text { clothes: } \\
\text { Cloth brushes } \\
\text { Shoe brushes } \\
\text { Washing brushes } \\
\text { Oil pots } \\
\text { Scissors } \\
\text { Spools } \\
\text { Knives; sacks } \\
\text { Hempen bags } \\
\quad \ldots . \\
\quad \ldots \\
\text {.... } \\
\text { Wrapping cloth } \\
\text { Quilts and mat- } \\
\text { tresses } \\
\quad \ldots . \\
\text { Special badges } \\
\text { Distinguishing } \\
\text { badges } \\
\quad \ldots . \\
\text { Puggarees } \\
\text { Flannel under- } \\
\text { wear } \\
\text { Flannel belly } \\
\text { bands } \\
\text { Woolen knit un- } \\
\text { derwear } \\
\text { Woolen knit } \\
\text { drawers } \\
\text { Woolen knit } \\
\text { gloves } \\
\text { Fur undergar- } \\
\text { ments } \\
\text { Collars } \\
\text { Woolen socks } \\
\text { WVadded gloves } \\
\text { WVadded drawers } \\
\text { Japanese socks }\end{array}$ \\
\hline
\end{tabular}

Besides the above, there are about 23,000 extra haversacks made annually by outside tailors to whom an order may be given together with the necessary cloth. 


\section{Manual Industry}

The influence exerted upon hard work by military industry is also not small. In the army and the navy factories, workmen for each particular branch of work are taken as far as circumstances permit from among the people in the same or similar trades. And as these men with special experience are, of course, paid better rates of wages than plain workers, hosts of artisans come from all parts of the country, to serve in the army and the navy. This is especially the case with the naval factories; in all the navy yards and arsenals the majority of men are possessed of more or less manual skill. In both the factories of the army and the navy, those manual workers are generally fitted into different works according to their special attainments, in order to enable them to work to the best of their capacity; for instance, carpenters, sawyers, coopers, joiners, etc., are made to work in the woodwork shop; blacksmiths, goldsmiths, etc., in the forge; casters in the foundry; lacquerers and painters in the lacquerering shop; plasterers, stone masons, roofers and bricklayers, etc., in the building department; tailors, shoemakers, etc., in the clothing factory; saddlers or harness makers in the harness factory; wheelwrights in the wagon factory; weavers in the woolen cloth factory; ship carpenters in the shipbuilding yard. This system is practiced with great advantage to the factories as well as to the workmen. It is therefore to the interest of all military factories to receive artisans in a respectful manner. These men have to observe some disciplinary rules in the factories, but, on the other hand, they can get security of position, with an income of more than what they would be able to realize in private work; besides, they are entitled to an allowance in case they are injured or sick, and to other relief, and moreover to pensions after a term of service. In the face of these possibilities, men who are endowed with manual skill suitable for military industry, and are free from family obligations, and within the prescribed limit of age, are naturally induced to go into the service of military factories. They are thus taken away in large numbers every year from general industry, and cause the 
wages of artisans to rise. The phenomenon is most noticeable in the factories of naval stations, where artisans of certain kinds readily find work among the people and get a comparatively nice living.

As regards the technical progress of the artisans employed in military factories, we find that its influence is inconsiderable. Most of the work in the factories is done by the division of labor, so that a workman gets only partial skill in the process of manufacture; moreover, many of the manufactures are articles peculiar to the army and the navy, and mainly products of mechanical work. For these reasons the manual arts of the people in general are affected but little by the work in military industries. Only the workmen who make small but complete articles in the iron or the woodwork line, or those employed in the clothing or the leather industry, find in their work great opportunities to develop their abilities.

The artisans residing in a place where military factories are located are benefited by the ample work and good pay caused by the scarcity of manual labor in that locality. But that is not all. They continually find work in the making of those innumerable small hand-made articles which are used in the factories but are purchased from the people instead of being made there, or in the making of that class of articles used every day in the homes of the officials and workmen of the factories. The work is so plentiful that many of them find their whole employment in the making of those articles for the factories alone. In this case it is not only the artisans in the same line of work as those employed in the factories who get the benefit, but also those in other lines of manual work, such as those who produce the miscellaneous articles which are wanted in the factories not only for the industry but for other uses and are used every day in the homes of the officials and workmen of the factories, are equally the recipients of the advantage.

Excepting only clothing, leather articles and small miscellaneous articles of iron or wood, the manufactures of military industry are made very little by manual work, so that there is almost no instance to speak of in which the former industry has proved a pressure or impediment to the latter. 


\section{CHAPTER IV \\ EFFECTS ON PRIMITIVE INDUSTRY}

The influence of military industry upon primitive industry is also evident in Japan, although it is not so large as that upon manufactures or commerce, and in some instances it obstructed the progress of the industry rather than aided it. Japan was called an agricultural country from antiquity, and even now agricultural products are its staple. Manufacturing industry made very slow progress, so that the influence it had upon agriculture was not remarkable until very recently. The industry of the army and the navy has made comparatively rapid development, but the great majority of its manufactures take but a little of its materials from the agricultural kingdom, and in this respect it can not be said to exert influence upon agriculture. The rise of the price of commodities and wages in general, consequent upon its absorption of raw materials and workmen, must have had comparatively serious effects upon the interests of agriculture. However, such an indirect influence is out of the reach of statistics and can not be made out with preciseness. In the following section, therefore, full space will be given to the statement of the direct advantages derived from military industry, with but a rough reference made to the indirect influences.

Besides agriculture, we are to write about the influences upon forestry and mining; but while there is not so much to be said of mining, forestry has received only slight influences, of which very few are worth mentioning.

Although the influence of military industry is noticeable on the different primitive industries other than these three, the comparison is too insignificant to be described and it will therefore be omitted. 


\section{Agriculture}

Among agricultural products, the principal materials used in the army and the navy industries are, for provision manufacture, rice, barley, wheat flour, rice flour, sugar, sesame, potatoes, greens, pickles, hops, straw ropes, straw bags, etc.; for clothing manufacture, hemp, hemp threads, hemp cloth, cotton threads, cotton cloth, paper,vegetable oils, thistle seed, vegetable dyestuffs, etc. ; and, for the manufacture of arms and ammunition and shipbuilding, hemp, hemp cloth, cotton, cotton cloth, vegetable oils, paper, lacquer, starch, etc. To these may be added the materials from stock farms, which are, beef for the provision industry; wool, hides and leather, animal oils, etc., for the clothing industry; hides and leather, animal oils, etc., for the other industries. With the exception of hops, all the above materials are produced by domestic farmers. Materials partly manufactured, as rice flour, wheat flour, sugar, hemp thread, hemp cloth, cotton thread, cotton cloth, paper, lacquer, dyestuffs, hides and leather, fat and oil, etc., are made by farmers, but, being by-work, it is carried on in only a limited degree, and such of these materials as are required by the army and the navy in large quantities are generally made by private factories, so that the farmers would only have to supply these factories with their raw products and have no large and direct advantage in respect of these materials. Soy used in provision factories and alcohol used extensively in various factories have some influence upon agriculture, as their raw materials are taken from farms. Common salt used in the factories is not without some interest to farmers, who produce this material as a side occupation.

Military industry has brought considerable advance upon some of the above-mentioned productions of agriculture. Instances of it may be given as follows:

In purchasing cattle for canning, the military provision factories pay a higher price than is paid in the general market and take particular care in selection. This has the effect of encouraging stock farmers to improve their cattle year after year. Rice, wheat and their flours are purchased by special 
contract with industrial associations. The government encourages and leads the association to better the grade of the produce, and so a steady progress is being made in that direction. In this way, also, is the organization of those industrial associations in the farming districts of Japan helped in no small degree to develop.

The careful discrimination by the authorities in the quality of the upper leather and the sole leather used for shoe making in the clothing industry of the government has encouraged the improvement of those materials, and its effects have of late come to the surface. The production of cowhide leather in the country has made remarkable advance, being now able to bring forth good sound material. The use of vegetable oils as material for leather preservators has also brought benefit to the industrial world.

Wool, the principal material for woolen industry, was formerly wholly imported from foreign countries, but since the Senju Woolen Cloth Factory, desirous to get a domestic supply of wool, set the example of shepherding and encouraged private enterprises, there has developed some wool growing in the country. The thistle seed for raising the wool of the cloth by combing, which was also imported before, is now entirely produced at home as the result of the encouragement extended to farmers to cultivate the seed by the above government factory in about the 25th year of Meiji (I892). These facts have added a good deal to the promotion of Japanese agricultural interests.

Besides what has been mentioned above, military factories have some influence upon such farm products as greens and fruits grown in their neighborhood. These agricultural products must of necessity be grown not far from the market, and as they are consumed by a large population of the factory officials and workmen and their family clustered in one locality, it is usual that their market prices keep higher than in other localities, which must, of course, make some difference in the income of the farmers who supply the products.

We shall now explain some of the disadvantages inflicted 
upon farm villages by military industry. The presence of a military factory at any place induces the young men in that locality to leave their farms for factory work. Farms become desolate, in consequence of the annual absorption of a large number of these men by the factory, labor becomes scarce, wages rise and the cost of production increases; often it goes to such an extreme that a farmer of small means is unable to hire help and has to barely keep his farm by the scant labor of the aged, the young and women. The military factory has also the unavoidable tendency of enhancing the price of all commodities in its locality above that in other places. That it is driving farmers to hard living is obvious from actual examples; the fact is best revealed in those newly-developed localities where naval stations have been planted, above all, in the neighborhood of Kure, Sasebo and Yokosuka. It is said that farm villages under such an influence often lose in the end from military industry.

\section{FORESTRY}

Timber is one of the principal materials employed in the military industry. It is required in large quantities by the industry, and the amount of money paid for it is also large. That military industry should have some influence upon forestry is clear. Up to this time, however, the influence has, unlike other cases, been destructive rather than promotive to the forestry of Japan. The forests have been laid waste, instead of being made productive. Besides common woods like cedar, pine, fir, chestnut and larch, the army and the navy use a great deal of the costly woods, such as chamaecyparis obstusa, selkova acuminata, querens serrata and chamaecyparis pisifera. These latter trees, especially, take a great many years to grow, and even if they are replaced with young trees immediately after being cut down, it is not an easy matter to restore the forest in any short space of time. The difficulty was made even greater in Japan by the following conditions: Prior to the Restoration, when yet without the means of communication and the great construction works as 
today, Japan was, except in the vicinity of towns, thickly forested with tall trees and possessed an abundance of good timber. After the Restoration, however, the initiation of the military industry caused large quantities of timber to be used for the construction of its factory buildings and as materials for its manufacturing works; at the same time the demand for timber was increased by the construction of barracks, government offices, and school houses, by the laying of railways (sleepers), the development of private shipbuilding, the opening of the telegraph and the rise of electric light enterprises (electric poles), etc. Added to the increased demand for timber, the improved facilities of communication in the interior made reckless disafforestation go on universally, so that it was feared, should it be suffered to continue, no wooded lands would be left in the country. In spite of that, the work of replanting in Japan long remained in neglect, and it was only in recent years that anything was begun in that direction. So the desolation of forests knew no limit. This state of things is attributable to the coaction of several causes and not to one, but it is not to be denied that military industry was a principal factor in the affair. Even now this industry is consuming the domestic timber in large amounts ever at an increasing rate, which, however, as forest planting is now well under way with hopes of development, would not cause any more ruining of the forest than at the present time. Be that as it may, it is largely the influence of military industry that has brought this rueful condition upon the forests in Japan, especially upon those of the good hard-wood trees, to which reference has already been made.

One of the advantages given to foresters by military industry is the application of machinery in their timber making, for the army and the navy factories were the first that adopted timber machines in this country, and, serving as model works, have induced private timber makers to use machinery. Another advantage to the interests of forestry is the opening up of ways to new forest regions, thus: military industry demands timber of larger sizes and higher qualities than are usual 
among the people, and pays even liberally for it; this finds market for the productions of retired parts of the country hitherto valueless owing to the difficulty of communication; and it acts as an incentive to, or hastens the execution of such works as making new roads, building bridges, opening new shipping routes and constructing railways, in order to facilitate lumbering. Instances are found in many places where circumstances of similar nature have much assisted the development of local forestry enterprises, and such should no doubt be recognized as a beneficial effect of military industry. Further, mention may also be made of advantages derived by timber producers relating to the purchase of timber by military industry. For example, such wood as may be used for the stock of small arms for the army (formerly beech was used; now walnut is in use instead) is not always produced where it is desired, though it is used in large quantities; so the purchase of the material had to be made through many merchants; but in recent years access was made to the industrial associations of the producing localities for a direct deal, with the result that the profit of the foresters has been increased considerably. It may be added as belonging to the same category that the government sawmills are of late seeing better profits from the direct purchase of large amounts of timber made by military factories.

\section{Mining}

The influence exerted upon mining by military industry is greater than that upon agriculture and forestry. Coal is an indispensable material as fuel in all the factories of military industry. Its use in Japan dates back to the Genroku Era (about 1700), when it was used among the people only in cooking or as fuel for salt pans, and it was not until 2 Ansei (1 855), the year of the establishment of the Naval Training Hall at Nagasaki, that it was used for factories ingeneral and for steamships. From that time up to the Restoration of Meiji, coal was used as fuel in the military factories established under the Tokugawa Shogunate. With the reorganization and enlargement of the factories after the Restoration, the amount of coal 
consumption grew larger every year, so that the supply had to be partly obtained from foreign countries. But at the same time, coal mining in this country made steady progress, and while the demand for coal has rapidly increased with the expansion of the army and the navy factories, the establishment of private factories, the increase of public and private vessels, etc., its production became so large that it amply covered the whole domestic demand and a quantity was even exported which to this day has always kept above the amount of the imports. Now that the consumption of coal by the people as well as by the ships of the navy has enormously increased, the amount for the army and the navy factories is not so large when compared with the whole consumption of the country; still, if all the factories related, to military industry, i.e., the iron foundry, the steel works, the dockyards, and the other private companies, are taken together with the military factories, it would make a great consuming power of coal in this country. Even though their consumption of coal is insignificant in the coal industry nowadays, the names of the military factories should ever remain connected with the coal mining of Japan for the service they did to the development of the industry when yet in its infancy, about the time of the Restoration of Meiji.

The coal mining in the 44th year of Meiji (I9II) shows a total output of $\mathrm{I} 7,632,7$ IO French tons of the value of 55,006 ,501 yen. Of this, I0,774,358 French tons were consumed at home, and while the amount of the imports in the same year was I $8 \mathrm{I}, 363$ tons $(\mathrm{I}, 546,794 \mathrm{yen})$, the exports reached 3,04I,347 tons $(17,898,613$ yen $)$. By these figures will be seen what progress the coal mining industry in Japan has made.

As regards iron, the government, as has been stated in the previous chapter, encouraged from both the military and the economic stand points the domestic industries of mining and refining iron, and went so far in the effort as to take to itself the work at the iron mines at Kamaishi and Naka Kozaka, and recently built an iron foundry, and started steel manufacturing in the arsenals of the army and the navy. In consequence of all 
these the production of iron has made a gradual increase. At the present time, the principal iron mines in Japan are the Kamaishi and Sennin mines. These mines are under private management, and have each a refinery. The amount of the homeproduced iron used by the iron foundry as part of its ore supply is 30,000 tons, worth about 600,000 yen, and the total production in the whole country is according to the returns for 44 Meiji (I9II) only I7,032,59I kwamme (about $82,75^{\circ}$ tons), worth $2,575,5 \mathrm{I} 4 \mathrm{yen}$. Iron mining in Japan has yet much room in which to develop; nevertheless, it may be said that the progress so far achieved is due wholly to the industries of the army and the navy.

Zinc is very largely used in the manufacture of articles for the army and the navy and is therefore an important material in military industry. Especially in Japan its chief consumer is the army and the navy factories. From ancient times zinc ore has been commonly found in combination with copper and lead ores, but it was not much sought after for the sole reason that its presence was detrimental to the refining of copper and lead. When, as a result of the Russo-Japanese War, there came about a large demand in Japan for zinc, no way was available to get this stuff in consequence of the disregard of the metal in the past. In the 38 th year of Meiji (1905), recourse was had to the exporting of zinc ore to foreign countries in order to import it after being refined there; and since then a large amount of the ore has been exported annually, mostly to Belgium and the rest to Hongkong, Germany and England, and though it was done as an "export," it was in truth entrusting those countries with the refining of such ore. However, for military or other reasons, the government has for several years past encouraged the home industry of refining zinc and succeeded in getting it done in this country, so that the importation of zinc is now showing a considerable decrease, and will, it is expected, totally stop before long. Thus we have another example of a mining industry developing through the progress of military industry.

Among other minerals used in military industry those that 
have made industrial development under the influence of the same industry, directly or indirectly, are copper, lead, saltpetre, etc. The contribution made by military industry to the mining of these minerals, both in management and in skill, is as noteworthy in these cases as in any other.

The following table shows the coal consumption of the factories of the army and the navy in the Ist year of Taisho (1912):

Coal Consumption of Army and Navy Factories, i 'Taisho (i9i2) ARMY

Tokyo Arsenal.

Osaka Arsenal. 76,517

Clothing Department 71,977

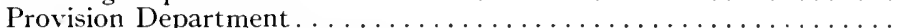

Senju Woolen Cloth Factory.

2,110

Railway Material Department.

\section{NAVY}

Yokosuka Naval Arsenal. ....................... I5,446

Kure Naval Arsenal. . . . . . . . . . . . . . . . . . . . . . . 105, I 47

Sasebo Naval Arsenal. . . . . . . . . . . . . . . . . . . . . . . . . . . . .

Maizuru Naval Arsenal. . . . . . . . . . . . . . . . . . . . . .

Ryojun Dockyard. . . . . . . . . . . . . . . . . . . . .

Naval Arsenal.

105,147
I I 998

14,300

I,845

3,426

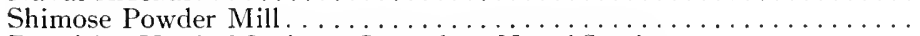

Repairing Yard of Ominato Secondary Naval Station. . . . . . . . .

Repairing Yard of Bako Secondary Naval Station. . . . . . . . . . .

Briquette Manufactory 


\section{CHAPTER V}

\section{EFFECTS ON COMMERCE}

The amounts paid out of the national Treasury for the military industry differ each year. According to the statistics for the last few years, the total expenditure for military and naval factories varies from $70,000,000$ yen to $80,000,000$ yen. The budget for the first year of Taisho (I9I2) shows it at about 75,000,000 yen, including the Ordinary Annual Expenditures, the Incidental Expenditure, and the Special Accounts. Of this amount, 52,000,000 yen is for the purchase of materials, I 8,400,000 yen for workmen's wages, and the balance for salaries, etc., and of the above purchases over $16,300,000$ y'en worth is imported. The materials purchased for the industry are several hundred varieties of articles from the heaviest machinery to the most diminutive thing, and if things of daily need of the officials and workmen are included, they will cover a very wide scope of articles sold in the market. The most of these purchases are made through native and foreign merchants and it is very seldom that any of the supplies are purchased direct from manufacturers. No doubt such a large sum expended for such numerous varieties of merchandise greatly influences commerce both domestic and foreign. It is particularly the case with machinery, or materials for arms and warships. These things come in large amounts when ordered, and require experience on the part of the dealers who receive the order; therefore, the purchases are made only among certain qualified parties, either by free contract or by limited tender. Such people are called "goyo shonin," that class of merchants who do government service as a specialty, as is also the case with the army and navy of any other country. They have a very close interest in the military industry, and every change in the activity of the industry is directly a change in the activity of their business movements; Their activity is best ex- 
hibited in times of war, and the profits they so derive are enormous, a fact that can easily be seen from many instances in which they have suddenly become great merchants, through the Civil War of the Ioth year (I877), the wars with China and Russia, etc. Most of the wealthy firms now prospering in this country are "goyo shonin" who are connected with military factories. All this is enough to explain what an influence the military industry has on the great central commerce. But its influence is not confined to this. It has also much to do with the commerce in the localities of military factories, where those merchants who deal in supplies outside of materials for manufacturing purposes, others who keep shops for articles of daily need for the officials and workmen of the factories, and even such small traders as keep eating houses, find benefit as much as their money invested will bring. However, people who have no interest in the military industry or in the district in which military factories are located may not feel any such influence at all. Often the influence of the military industry is felt badly in the general economy of the country when perchance an excessive outlay made on account of military works has brought about a general depression and dull trade. Such an experience is being had in Japan at the present time.

In brief, the military industry has as great an influence upon commerce as it has upon other industries,---sometimes even a greater influence. The center of industry or commerce of a country being as it is, it of ten becomes the ruling power of the money market and foreign trade, as is clear from instances which show well enough how great its influence could be.

\section{Home Trade}

The materials required in the military industry are taken as much as possible from domestic products for the purpose of attaining "independence in military equipment" and of conforming to the industrial policy of this country to encourage the development of home production. This has greatly increased the demand for the native materials in recent years. 
Moreover, also for the same purpose, the manufacture of warships and other finished articles of war is as a rule carried on at home, no foreign goods being imported except those foreign patents and other objects of special workmanship impossible to make in Japan. This, tending to increase the manufacture of arms and warships, and other works of military industry in general, has, together with the increase of the demand for the home-produced materials, had the effect of promoting the home trade, increasing its business transactions very greatly. It is to be especially noted that, as the result of careful selection made in the purchase of military supplies by the authorities, the custom has been established among traders to refrain from dealing in poorly-made articles, much to the maintenance and elevation of business morality.

The following are some of the articles used as materials at military factories, which are of domestic production and are in considerable demand at the present time, to show to what extent the home trade may be influenced by the military industry:

Files, crucibles, copper bars, copper plates, brass bars, brass plates, brass pipes, copper pipes (part), ${ }^{1}$ electric wire and cable, copper, lead, steel plates, tool steel and common steel (part), tools, instruments, machines and their accessories, carbon bars and carbon plates (part), hemp, hemp cloth, cotton, gum, paper, ebonite, thick hemp cloth, hemp cloth for padding, hemp cloth for lining of caps, hemp cloth for tents, cotton manufactures (spindle band, spun yarn), visors, thick cotton cloth, hempen manufactures (spun yarn, selvage yarn, hempen ropes), spun cotton cloth, calico, khaki woolen cloth, woolen cloth for gaiters, mompa (a kind of cotton flannel), brick, timber, glass plates, glass tubes, paper bags, straw bags, wooden boxes, ropes, tops with roll, chemicals (pharmaceutical) (part), alcohol, starch, vegetable oil, animal oil, sulphuric acid, other acids, wax, solid salt, powder salt, thistle nuts, sole shoeleather (surface), upper shoe leather, sole shoe leather (middle),

'The articles followed by the word "part" are only partly purchased at home, the rest being imported. 
spikes, brim leather, jowl piece, hide manufactures, (belting, oxhide, strap leather, leather belt), unsai (thick cotton stuff), cotton threads, upper leather sewing yarn, Berlin wool for hosiery, cotton belts, eyelet strings, badge paper, paddings, warming belts, hides and leather (for arms), ammonia, zinc (part), saltpetre, pig iron (part), alloys of iron (part), cement, coal, coke, hematite (part), clay for crucibles (part), lead (part), copper, barley flour, potatoes, salt, wheat flour, sugar, soy, mirin (sweet sake), vegetables for pickles, rice flour, sesame, materials for artificial wool (for socks and gloves), wool, wool grease (leather oil), sulphate of soda, dyestuffs (acetic indigo ball, acetic ammonia).

The influence that the military industry has upon home trade is not confined to the business in the industrial materials mentioned above. In fact the benefits are equally shared by all trades. At any place where factories are planted, business is enlivened and bustling leading to the development of the cities and towns, and directly or indirectly, of all kinds of trades in the whole extent of the district.

It may be added that some of the articles made in the bywork of the military industry for sale in the general market or on application often have considerable effect upon domestic and foreign trades. The Tokyo and Osaka Arsenals are using their spare power out of the regular work in the manufacture of articles such as can not be made by any private factory on account of the legal restriction or of deficiency in its equipment for the work, as well as in the manufacture of such articles as are being largely imported. These articles, together with the by-products of the arsenals' works, are sold through the market or made for renting, all of the receipts so aggregated each year being as shown in the following table. Besides this work of the two arsenals, similar work is being done by other military factories; for instance, the Senju Woolen Cloth Factory makes blankets, artificial felt and other woolen goods for the general use of the people, while the Naval Powder Mill offers its byproduct, sulphate of soda, to the open market. All these are affecting directly or indirectly the interests of domestic and foreign trade. 


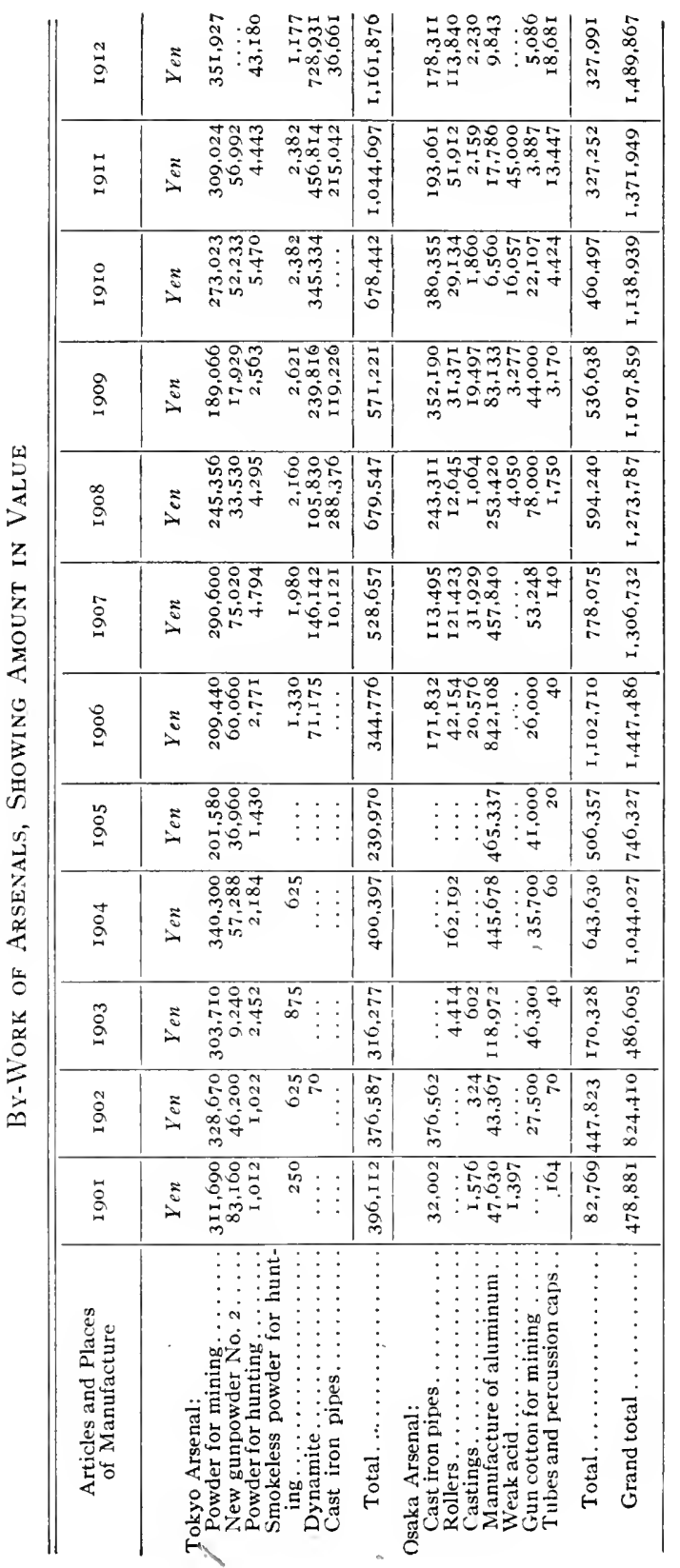




\section{Foreign Trade}

The arms, war vessels and materials for military industry imported since the Restoration of Meiji up to the present time amount to an enormous sum. It is evident from an examination of the history of the Japanese foreign trade that the excess of imports during most of this time is mainly due to the large amount of imported war materials. From the 2 d year of Meiji (I869), in which the military system of Japan was reformed, and improved arms and war vessels were decided to be adopted, to the time of the Satsuma Rebellion, the continual enlargement of military preparations kept the foreign trade always with an excess of imports. The same condition continued until $\mathrm{I} 3$ or $\mathrm{I} 4 \mathrm{Meiji}$ (I880 or I88I). Then the trade began to increase on the side of exports, and this with the slackening in the work of the military preparations went to keep the balance on the favorable sideuntil 27 Meiji (I 894), the year the Sino-Japanese War commenced, with the exception of the years $2 \mathrm{I}$ and $23 \mathrm{Meiji}$ (I888 and I890), in which the imports exceeded the exports as a result of the Itsukushima and three other warships being ordered from abroad. But again there came an expansion of military preparations during and after the Sino-Japanese War, and all at once the amount of imports rose to a point three times as much as the amount of exports; next came the new rule over Formosa and then the North China affair of 33 Meiji (I900), necessitating the expansion of military preparations, which continued until 37 Meiji (1904), the year of the Russo-Japanese IVar, and kept the imports in excess all that while, in spite of the development and a very good showing of exports. The requirements of the Russo-Japanese War and of the post-bellum expansion of military preparations caused the excess of imports to grow, as the purchase of arms and war vessels from abroad grew larger. It is clear from these facts that in Japan the enlargement of military preparations is the most powerful agent that determines the balance of imports and exports. Most recently, however, the government, in pursuance of the policy of independence of war, adopted protectionişm for all articles con- 
nected with military industry, be it arms, ships, or any other war materials, and as a result the amount of imports has not a little decreased. This is most remarkably the case with the navy. Before the Russo-Japanese War, the Japanese Navy built by its own hand only small warships of about 3,00o tons, such as the Hashidate, Akitsushima, Tsushima, Niitaka and Otowa, the materials having all been imported even for those, while all the battleships and armored cruisers taking part in the same war were built in foreign dockyards. However, the war made Japan discover the necessity of building all large ships at home and caused a revolution in the shipbuilding industry of the country.

To be fitted for the new work, machinery was purchased from foreign countries for several years subsequent to the war. At first all materials of steel were imported, but later they were manufactured at home, as the dockyard factories were equipped to the full, only the ore and pig iron having to be imported as their raw material. Side by side with this, there developed iron foundries and the industry of munition manufacture at large, and as those advances were made, the demand for foreign goods gradually receded. Today such demand is limited merely to patented and other special articles, and certain kinds of machinery, and therefore the amount of imports is greatly falling off.

Thus imports are gradually decreasing as the home production of the military requirements increases; yet, at present these materials occupy a principal place in imports and are as important a factor in the Japanese foreign trade as they ever were. To enable the reader to gain an idea of what influence the military industry has upon the foreign trade, we shall add in the following pages a list of the foreign articles in demand at present by the army and navy, a table giving a comparison of annual importations (in value) of munitions made in the past years, and tables showing the imports of the principal materials for military industry-iron and other metals, coal, and materials for woolen cloth manufacture. 
Articles imported at present:

Hemp cloth, mompa (a kind of cotton flannel), threads for sole sewing, Berlin wool for hosiery, threads for leather sewing machine, spikes, glass for eyeglasses, machine oil, olive oil, olein, alcohol (to make up the domestic shortage), corrosive sublimate, fuchsine, diphenul amine, card clothing, leather manufactures (belts, rubbers), emery polishers, paper for blueprinting, nitrate of soda, chemicals (pharmaceutical), machinery, machine accessories, steel pipes, tin plates, tool steel, platinum wires, iron plates for electricity, steel wires, steel plates, carbon bars, carbon plates, special steel, nickel, antimony, semi-manufactured steel for machines, files, nails, tin, aluminum, nickel, alloys of iron, zinc, lead, pig iron, tops for woolen cloth manufacture, noils for woolen cloth manufacture, tin, lead, saltpetre, hematite, clays for crucibles, hops, wool grease (leather oil), gelatin orange (pigment) materials for leather, fur, wool, dyestuffs, belts and materials, India rubber, varnishes, shellacs, ammonia for refrigerating.

Comparison of Annual imports of Munitions, in Cost Value

Years

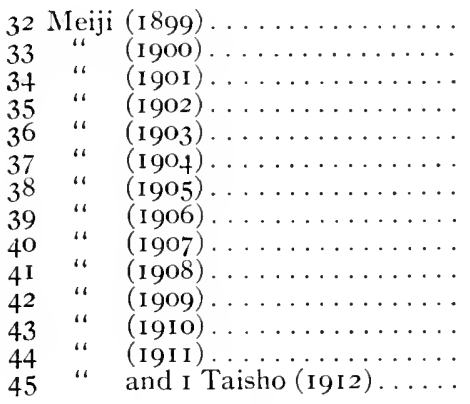

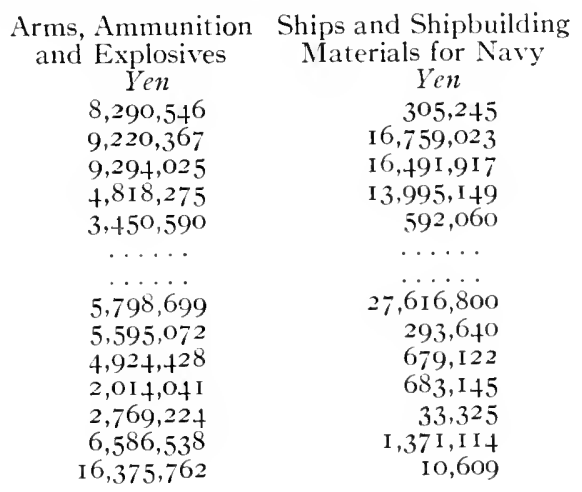

Besides what is shown in the above table, there are to be considered the imports of materials for woolen cloth manufacture tabulated hereafter, ${ }^{\mathrm{I}}$ and imports of the materials for the clothing and provision industries of the army, amounting to about 300,000 yen annually. 


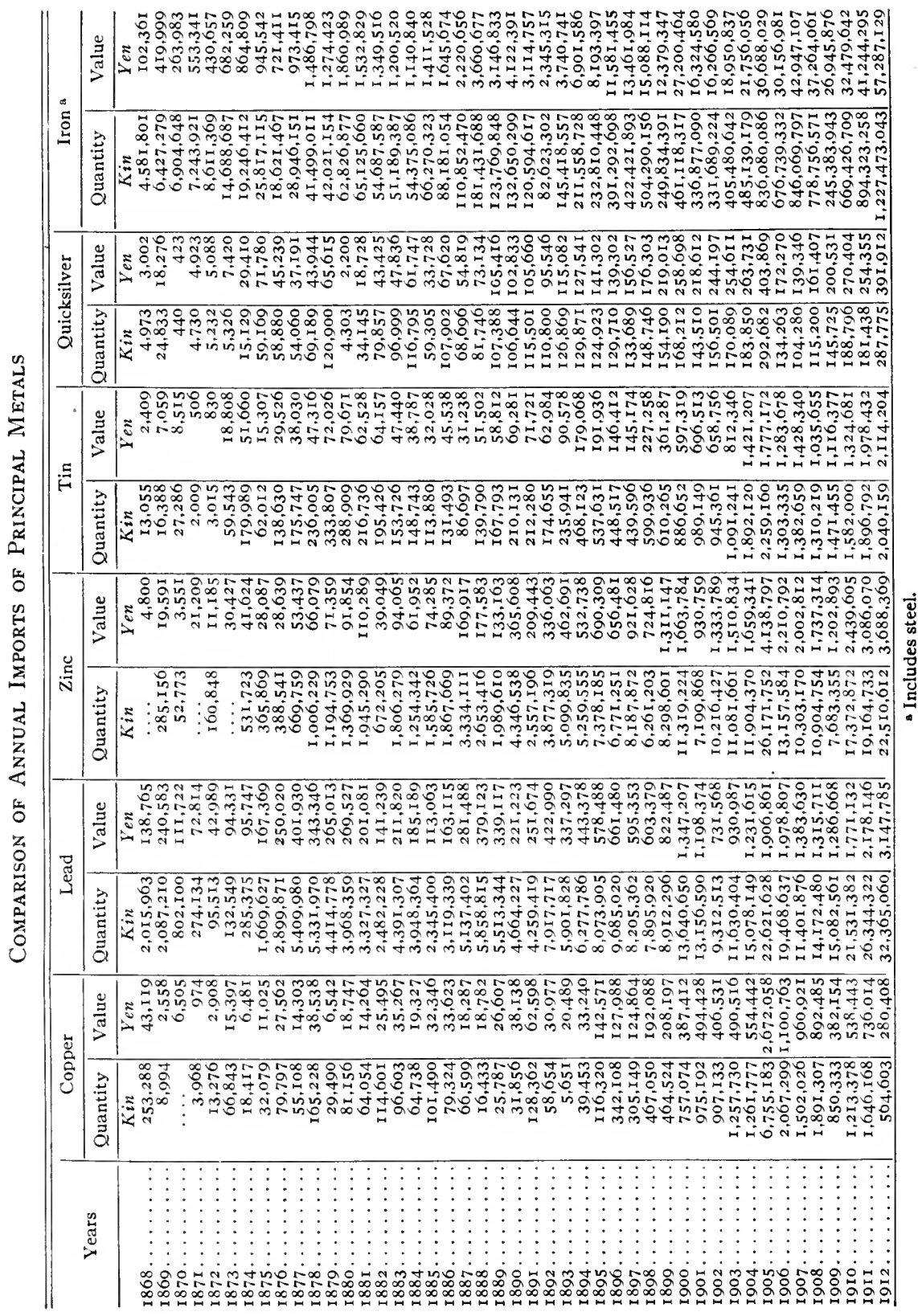


Iron Wires, Iron Bars and Iron Plates Imported

\begin{tabular}{|c|c|c|c|c|c|c|}
\hline \multirow{2}{*}{ Countries } & \multicolumn{2}{|c|}{43 Meiji (гяло) } & \multicolumn{2}{|c|}{44 Meiji (Igr I) } & \multicolumn{2}{|c|}{45 Meiji (I9I2) } \\
\hline & Quantity & Value & Quantity & Value & Quantity & Value \\
\hline $\begin{array}{l}\text { England . . } \\
\text { France ... } \\
\text { Germany . } \\
\text { Belgium . . } \\
\text { Austria . . . } \\
\text { Sweden . . } \\
\text { U. S. A. . . } \\
\text { Others . . . }\end{array}$ & $\begin{array}{r}K \mathrm{in} \\
\mathrm{I} 6 \mathrm{1}, 954,676 \\
\mathrm{I}, 200,798 \\
130,327,041 \\
73,856,131 \\
\mathrm{I}, \mathrm{I} 38,004 \\
2,062,213 \\
\mathrm{I} 1,755,710 \\
\mathrm{I} 2,532\end{array}$ & $\begin{array}{r}Y e n \\
\text { I 2, I 76, I98 } \\
70,625 \\
4,933,755 \\
2,862,076 \\
389,430 \\
244,017 \\
993,332 \\
688\end{array}$ & $\begin{array}{r}\text { Kin } \\
199,140,547 \\
1,469,629 \\
147,227,759 \\
54,570,657 \\
3,634,185 \\
4,836,772 \\
37,661,028 \\
556,238\end{array}$ & $\begin{array}{r}\text { Yen } \\
14,556,076 \\
150,190 \\
5,439,732 \\
2,027,830 \\
583,747 \\
361,498 \\
2,803,606 \\
20,462\end{array}$ & $\begin{array}{r}\text { Kin } \\
255,806,275 \\
248,100 \\
205,722,497 \\
80,052,280 \\
1,085,534 \\
3,095.084 \\
140,230.399 \\
4,655,789\end{array}$ & $\begin{array}{r}Y e n \\
\text { I 7,742,316 } \\
23,014 \\
8,120,706 \\
3,028,842 \\
241,824 \\
252,108 \\
8,020,268 \\
223,298\end{array}$ \\
\hline Total. & $382,307,105$ & $2 \mathrm{I}, 670, \mathrm{I} 2 \mathrm{I}$ & $449,096,8$ I 5 & 25,943, I 4 I & $690,895,958$ & $37,652,376$ \\
\hline
\end{tabular}

Iron Tubes and Iron Pipes Imported

\begin{tabular}{|c|c|c|c|c|c|c|}
\hline \multirow{2}{*}{ Countries } & \multicolumn{2}{|c|}{43 Meiji (rgro) } & \multicolumn{2}{|c|}{44 Meiji (I9II) } & \multicolumn{2}{|c|}{45 Meiji (1912)a } \\
\hline & Quantity & Value & Quantity & Value & Quantity & Value \\
\hline $\begin{array}{l}\text { England ... } \\
\text { Germany . . } \\
\text { Belgium . . } \\
\text { U. S. A. . . } \\
\text { Others . . . }\end{array}$ & $\begin{array}{r}\text { Kin } \\
\text { I } 3,448,903 \\
5.5 \text { I } 5,382 \\
185,863 \\
25.351,075 \\
267,528\end{array}$ & $\begin{array}{r}\text { Yen } \\
\text { I, I9I,624 } \\
441,961 \\
12,604 \\
1,557,618 \\
36,997\end{array}$ & $\begin{array}{r}K \text { Kin } \\
16,390,967 \\
12,782,874 \\
27,076 \\
25,924,245 \\
330,055\end{array}$ & $\begin{array}{r}\text { Yen } \\
\mathrm{I}, 594,526 \\
\mathrm{I}, 036,912 \\
2,717 \\
\mathrm{I}, 58 \mathrm{I}, 804 \\
52,417\end{array}$ & $\begin{array}{r}\text { Kin } \\
1,337,408 \\
1,237,462 \\
33,235 \\
2,352,266 \\
2,351\end{array}$ & $\begin{array}{r}\text { Yen } \\
13,278,192 \\
12,772,161 \\
332,674 \\
33,577,368 \\
26,855\end{array}$ \\
\hline Total. & 44.768 .751 & $3,240,804$ & $55,455,217$ & $4,268,376$ & $4,962,722$ & $59.987,250$ \\
\hline
\end{tabular}

IRON INGOTS IMPORTED

\begin{tabular}{|c|c|c|c|c|c|c|}
\hline \multirow{2}{*}{ Countries } & \multicolumn{2}{|c|}{43 Meiji (I9I0) } & \multicolumn{2}{|c|}{44 Meiji (I9II) } & \multicolumn{2}{|c|}{45 Meiji (I9I2) a } \\
\hline & Quantity & Value & Quantity & Value & Quantity & Value \\
\hline $\begin{array}{l}\text { China...... } \\
\text { Kantoshu. . } \\
\text { England... } \\
\text { Germany . . } \\
\text { Sweden . . } \\
\text { U. S. A... . } \\
\text { Others... . }\end{array}$ & $\begin{array}{r}K \text { in } \\
52,821,391 \\
\ldots \ldots \\
128,291,499 \\
2,272,653 \\
3.882,269 \\
136,301 \\
481\end{array}$ & $\begin{array}{r}\text { Yen } \\
965,136 \\
\ldots \ldots \\
2,601,992 \\
138,190 \\
263,740 \\
2,455 \\
680\end{array}$ & $\begin{array}{r}K \text { in } \\
94,806,368 \\
65 \\
214,029,897 \\
3,838,009 \\
10,618,126 \\
45,360 \\
248,501\end{array}$ & $\begin{array}{r}\text { Yen } \\
\text { I,8 I } 7,606 \\
5 \\
4,705,229 \\
\text { I } 21,588 \\
500,747 \\
1, \text { I I I } \\
\text { I9.984 }\end{array}$ & $\begin{array}{c}K \text { in } \\
17,791,2 \text { I9 } \\
\ldots \ldots \\
267,612,231 \\
17,440,205 \\
10,673,723 \\
1,051,688 \\
85,953,805\end{array}$ & $\begin{array}{r}\text { Yen } \\
451,862 \\
\ldots \\
5,970,985 \\
501,880 \\
480,669 \\
27,209 \\
1,962,110\end{array}$ \\
\hline Total. . & I $87,404,594$ & $3,972,193$ & $323.586,326$ & $7,166,270$ & $400,522,87 \mathrm{I}$ & 9.394 .715 \\
\hline
\end{tabular}

. 45 Meiji is the same as I Taisho. 
Materials Imported for Woolen Cloth Manufacture

\begin{tabular}{|c|c|c|c|}
\hline Articles & 43 Meiji (I9Io) & 44 Meiji (I9I I) & 45 Meiji (I912)a \\
\hline 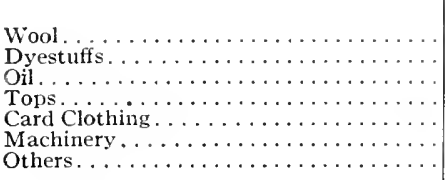 & $\begin{array}{c}Y e n \\
\mathrm{I}, 455,520 \\
13,510 \\
54,263 \\
1,116 \\
13,956 \\
25,535 \\
29,947\end{array}$ & $\begin{array}{r}\text { Yen } \\
\mathrm{I}, 389,262 \\
22,283 \\
29,399 \\
2,411 \\
7,342 \\
46,205 \\
30,750\end{array}$ & $\begin{array}{r}Y e n \\
1,559,056 \\
28,909 \\
35,947 \\
\ldots \ldots \\
2,140 \\
105,660 \\
27,570\end{array}$ \\
\hline Total..... & $I, 593,847$ & $I, 527,652$ & $1,759,282$ \\
\hline
\end{tabular}

${ }^{2} 45$ Meiji is the same as I Taisho.

Annual Imports of Coal

\begin{tabular}{|c|c|c|c|c|c|}
\hline Years & Quantity & Value & Years & Quantity & Value \\
\hline & Tons & Yen & & Tons & Yen \\
\hline I $868 \ldots \ldots \ldots \ldots$ & 3.967 & 33.754 & $1891 \ldots \ldots \ldots \ldots$ & 14,990 & I 42,9 I 8 \\
\hline I $869 \ldots \ldots \ldots \ldots$ & 7, I 1 I 2 & 96,739 & I $892 \ldots \ldots \ldots \ldots$ & 12,725 & I 05,380 \\
\hline $1870 \ldots \ldots \ldots \ldots$ & 5,674 & 24.963 & 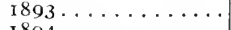 & 7,505 & 81,707 \\
\hline $1871 \ldots \ldots \ldots \ldots$ & 9,070 & 145,237 & $1894 \ldots \ldots \ldots \ldots$ & 37,545 & 472,757 \\
\hline $1872 \ldots \ldots \ldots \ldots$ & 10,733 & 179.758 & I $895 \ldots \ldots \ldots \ldots$ & 69,482 & 853,080 \\
\hline I $873 \ldots \ldots \ldots$ & 10,522 & $236,7 \mathrm{II}$ & $1896 \ldots \ldots \ldots$ & 49.919 & 519.380 \\
\hline $1874 \ldots \ldots \ldots \ldots$ & 8.934 & 99.960 & $1897 \ldots \ldots \ldots \ldots$ & 69,676 & 578,570 \\
\hline $1875 \ldots \ldots \ldots \ldots$ & 12,752 & 147,513 & I $898 \ldots \ldots \ldots \ldots$ & 42,635 & 399,189 \\
\hline $1876 \ldots \ldots \ldots$ & I 9,166 & $193,66 \mathrm{I}$ & $1899 \ldots \ldots \ldots \ldots$ & 51,563 & 937,094 \\
\hline $1877 \ldots \ldots \ldots$ & I9,035 & 159,073 & $1900 \ldots \ldots \ldots \ldots$ & 99,449 & $2,100,054$ \\
\hline $1878 \ldots \ldots \ldots \ldots$ & 36,444 & 257,122 & $1901 \ldots \ldots \ldots \ldots$ & I 13,536 & $2,542,133$ \\
\hline $1879 \ldots \ldots \ldots \ldots$ & $25.7 \mathrm{II}$ & 164,636 & $1902 \ldots \ldots \ldots \ldots$ & 73,727 & $\mathrm{I}, 298,374$ \\
\hline $1880 \ldots \ldots \ldots \ldots$ & 22,207 & 156,227 & $1903 \ldots \ldots \ldots \ldots$ & I 2 I, 3 I 7 & $1,972,923$ \\
\hline $1881 \ldots \ldots \ldots \ldots$ & 33,227 & 256,625 & $\mathbf{I} 904 \ldots \ldots \ldots \ldots$ & 622,831 & $12,199,884$ \\
\hline $1882 \ldots \ldots \ldots \ldots$ & 22,076 & 149,716 & $x 905 \ldots \ldots \ldots \ldots$ & 298,320 & $5,464,722$ \\
\hline $\mathbf{I} 883 \ldots \ldots \ldots$ & 17,242 & I03,322 & I $906 \ldots \ldots \ldots \ldots$ & 21,855 & 259,990 \\
\hline $1884 \ldots \ldots \ldots \ldots$ & 4,246 & 21,685 & I $907 \ldots \ldots \ldots \ldots$ & I 8,609 & 333,957 \\
\hline I $885 \ldots \ldots \ldots \ldots$ & 10,785 & 85,038 & $1908 \ldots \ldots \ldots \ldots$ & 30,885 & 629,867 \\
\hline I $886 \ldots \ldots \ldots \ldots$ & 7,529 & 65.383 & I $909 \ldots \ldots \ldots \ldots$ & I I 5,028 & $1,090,735$ \\
\hline I $887 \ldots \ldots \ldots$ & I I.734 & 56,275 & $1910 \ldots \ldots \ldots \ldots$ & I 73.225 & I,496,9 I 6 \\
\hline I $888 \ldots \ldots \ldots \ldots$ & $4.34 \mathrm{I}$ & 29,880 & I 9 I I $\ldots \ldots \ldots \ldots$ & 181,363 & $1,546,794$ \\
\hline I $889 \ldots \ldots \ldots \ldots$ & 4.520 & 40,0 I 5 & I9I $2 \ldots \ldots \ldots$ & 305.882 & $2,408,867$ \\
\hline I $890 \ldots \ldots \ldots \ldots$ & I I ,494 & 110,497 & & & \\
\hline
\end{tabular}




\section{CHAP'TER VI \\ EFFECTS ON COMMUNICATION}

The movement to places where military factories are located from other places in the country, and from colonies and foreign ports; the movement of great quantities of implements, machinery, and materials relating to military industry, out of the localities of factories to various points; or the increased movement of commodities into and out of the cities and towns newly formed or expanded by the presence of military industry--these have naturally had a great effect on the development of the means of communication between those factory localities and others as, for instance, traffic newly created or facilitated by the opening of a building, or repairing, or extending of railways, roads, bridges, shipping routes, vessels, telegraph and telephone lines, etc. Although no doubt can be en- tertained regarding the influence of military industry upon communication-upon all such means of communication and all those cases of the movements of goods-it is a difficult matter to distinguish this influence from other influences or causes and set it forth in concrete form, in connection with all and every one of the localities of military factories. In fact, in many cases this is true. The hardest cases are when it is attempted with large cities like Tokyo and Osaka, where the military factories have existed from earlier times than in other places and have made gradual development along with the development of the cities which commenced with the Restoration of Meiji. There are some truck roads, river facilities, roads, bridges, telegraphs, telephones for the special use of the military factories, but they are not worth describing as viewed from the side of general traffic.

In other places, where there are military factories and which have existed as cities from early days, traffic has developed almost under the same conditions as in those large cities, and 
there is nothing that can be mentioned as a special influence of the military factories. The influence of military industry is discernible with comparative clearness only in some of the means of communication for those newly opened regions where some of the naval ports have been located, and in ship lines connecting this country with these foreign lands where there are produced such articles as are imported in large quantities for the military industry.

While, in general, military industry has had the effect of developing communication-not only inland, but also with the colonies or with foreign countries - it often has proved the contrary. It is seriously hindering the sea traffic in those regions coming within the territories of the naval ports wherein the grounds of military factories are included by prohibiting the entrance of ships or else restricting it under certain tonnage limits.

We shall now explain those influences of military industry upon communication that are discernible by dividing them into the two classes of land carriage and water carriage.

\section{Land Carriage}

It is quite difficult to state the military influence upon the development of land carriage apart from other influences which might have acted upon it at the same time; but as we have stated in the previous section, such of the means of communication in the districts of the naval ports as railways which connect the ports with the main lines can be considered as having been born distinctly under the influences of military industry. So in the following pages we shall briefly describe some of the land communications around those naval ports, giving a separate account for each of the localities.

\section{Yokosuka and Its Connections}

The construction of the main line of the Tokkaido Railway, which was started in January, I 9 Meiji ( I 886), was followed by the construction of a branch line of ten miles and five and one half chains connecting Yokosuka with the main line at Ofuna, the work being started in April, 20 Meiji (I887). This branch 
line was inaugurated in June, 22 Meiji (I889), and upon the completion of the main line (Tokyo-Kobe) in the following month, quite revolutionized the land communication with Yokosuka and points in its neighborhood, where thenceforward the passengers and commodities were more and more collected and dispersed. When in 37 Meiji (1904) there was a general enlargement of military factories on account of the Russian War, a station called Taura was added on this line to facilitate communication with Uranogo Village, the place where the arms manufactory of the Yokosuka Arsenal is situated. Now in thinking of this extension of railway to Yokosuka, it will be easy to see that, if that place, then an out-of-the-way village of farmers and fishermen to which access was had only by water, as by land access was next to impossible, had been left to itself and were without the establishment of a naval station, especially of an arsenal or dockyard, things would have been quite contrary. There would never have been a branch line extended there, nor would it ever have been even dreamed of that such quick work should be made of railway construction as was witnessed in the extension of the line, completing it at the time when the main line itself was not yet through, and that therefore such ready construction of a line to Yokosuka is wholly ascribable to the position of the locality as a place of naval industries where traffic steadily grew heavy and both military and economic requirements demanded railway connection of that place with the outside world.

As to other means of communication in special connection with the naval town, there are the Uraga Stage (between Uraga and Yokosuka), the Nagai Stage (between Yokosuka and Nagai), the Uraga Motor Car (Between Yokosuka and Uraga). Each has a fairly good number of passengers, mostly of the arsenal officers and workmen, who take daily passage in them from their country dwellings.

\section{Kure and Its Connections}

Kure is a naval port lying at a point over ten miles off of the Sanyo Railway Line. Between the Sanyo Line and Kure, out to the coast line, it is hill after hill and allows of no easy pas- 
sage, which naturally made the early-time communication between this place and neighboring localities, especially Hiroshima, accomplished generally by sea. In the years 24 and 25 Meiji (I891 and I892) the work on the main line of the Sanyo Railway gradually made headway and the line was extended through the section near Kure. There the distance between the line and Kure was only a short one, but on the other hand the formation of the country was such that to construct a railway required tunneling work of so difficult a nature and at so many places that it would involve heavy outlay of expense. This in the condition of the traffic, etc., in those days was by no means a remunerative work for a private company to undertake and therefore no intention of immediately building a branch line over that district was had by the people of the Sanyo Railway Co. But then Kure was the site of a naval port wh:ch had the prospect of being greatly enlarged and becoming important, so that both from military rèquirements and for the future development of the economic conditions of those localities the government took the responsibility of setting apart under the Railway Law $^{1}$ a railway of twelve miles and thirty-five chains between Kure and Kaidaichi for the government's First Period Railway Construction, to be completed in twelve years from the time it was laid down. The War of 27 and 28 Meiji (1894-1895) and the consequent expansion of national expenditures, however, hindered the realization of the work, but at last the railway was begun in 33 Meiji (I900). The work progressed with due success, and when the Russo-Japanese War came it was pushed with redoubled force, and in November, 37 Meiji (1904), the whole line of the railway was completed. For the sake of convenience, the government leased the railway to the Sanyo Railway Co. and made it open the line for traffic on December I of the same year. However, as in 39 Meiji (I 906) the Sanyo Railway was bought up by the government by the enforcement of the law of railway nationalization, the whole system of the railway, including the Kure Branch Line, came under

${ }^{1}$ Law No. 4, issued June 20, 25 Meiji (1892). 
official management. This facilitated the traffic or connection of the main and the branch lines very much. Especially improved was the communication between Hiroshima and Kure, where more than ten trains were run every day. Now, how has this railway to Kure come to exist? Just as the city of Kure itself has developed to its present state through the establishment of the naval depot, especially of the arsenal, so has the railway come to find its existence. If Kure had been without the naval arsenal, it would never have expected to see any railway built to it.

An electric car service is facilitating local traffic in Kure. The company was started as the Kure Tramway Co. in 39 Meiji (1906). Afterward it introduced the electric system and altered its name to the Kure Electric Railway Co. Later it was again altered to the present Hiroshima-Kure Electric Power Co.

\section{Sasebo and Its Connections}

In I9 Meiji (I886) a proposition for constructing a Kyushu railway gained influence among officials and business men of Fukuoka, Kumamoto and Saga Prefectures. After many meetings had been held, the matter was at last decided, and a committee was elected to organize the company. Just at that time the government started the construction of a naval station at Sasebo in Nagasaki Prefecture, and considerable traffic of business people and laborers was being established to and from the newly-appointed place. Reference was made to this place in the application filed in January, 20 Meiji (I887), by the organizing committee of the Kyushu Railway Co., which in one passage reads as follows: "Sogi (a terminus of the projected Kyushu railway line) is but 3 ri ( $7 \frac{1}{2}$ miles) from Sasebo, a distance that can be covered in a few moments' time. Once the railway connection between Sogi and Kumamoto (site of a garrison) is completed, it should not require quite half a day to send the garrison troops, arms and supplies from Kumamoto out to the naval station; and thus in an emergency the forces of both the army and the navy can be concentrated in 
readiness to start overseas at a moment's notice, to the great facilitation of our military movements." In February of the same year a petition was filed by a party in Nagasaki Prefecture for constructing a railway between Nagasaki and Sasebo, connecting with the Kyushu Railway at Sogi. This petition also laid stress upon the naval port of Sasebo and gave it as the principal object for their project. After the filing of this petition, the government saw the advisability of uniting the two railway enterprises and so notified the governors of the interested prefectures. Thereupon the two schemes were united into one and came under the cooperation of the people of the four prefectures, of Fukuoka, Saga, Kumamoto and Nagasaki. The railway construction was started, but it had hardly made any progress when the government, enforcing the Railway Law, ${ }^{1}$ ordered part of the Kyushu Railway line, which begins at Saga and ends at Sasebo and Nagasaki, set apart for the government construction (Ist Period), to be completed in twelve years after starting the work. Later, however, the work again came to be conducted by the railway company, and rapid progress was made after the war with China, the line from Sogi to Sasebo being finished in 3I Meiji (I 898). Soon the line to Nagasaki (from Sogi) was also opened, and then railway facilities from Sasebo as a center to Moji, Kumamoto and Nagasaki were at last obtained, a remarkable development of communication. Thus the Sasebo Line of the Kyushu Railway owes its origin and speedy completion to the naval port of Sasebo, the existence of which gave rise to strong military and economic reasons for this railway construction. In other words, the naval station of Sasebo and especially its essential part, the arsenal, have had a very large influence on the land communication of that place and its. neighboring localities.

\section{Maizuru and Its Connections}

The government decided to start construction of railways from Kyoto, and Himeji in Hyogo Prefecture, or Tsuchiyama,

${ }^{1}$ Law No. 4, issued in June, 25 Meiji (1892). 
to Maizuru, under the Railway Act,${ }^{1}$ making either the line from Kyoto or from Tsuchiyama the first division; but it was stipulated that, if any parties desired to organize a company for constructing any such railway not yet under construction, they should be allowed to do so by the sanction of the Diet. When the Sino-Japanese War broke out and the government for pecuniary reasons was unable to start such work promptly, in 28 Meiji (I 895), after the same war, the establishment of the Maizuru Naval Station in the program of the second extension of Japanese naval power was decided upon in the Diet, and in the following year, in the month of May, the Naval Special Construction Branch was set up at Maizuru. And at just this time, from about the end of 28 to 29 Meiji (I 895 to I896), as an effect of the Sino-Japanese War, all enterprising persons were eager to start some kind of undertaking. So these par-, ties, seeing the future prospects of starting a government railway to Maizuru before long and of the economical development of the neighborhood of the same port, decided to construct a railway to Maizuru. One party applied for the construction between Kyoto and Sonobe, a part of the line from Kyoto to Maizuru, organizing the Kyoto Railway Co., and another party, the Hankaku Railway Co., to construct a railway between Kanzaki and Fukuchivama, a part of the line from Osaka to Maizuru passing through Hyogo Prefecture. These companies were licensed, and the former was organized in November, 28 Meiji (I 895) and the latter in September, 29 Meiji (1896) and both companies completed construction by February, 30 Meiji (I 897) and started to run, but as the railway for both companies did not pay and they were in very difficult circumstances, it was out of the question to extend the line to Maizuru. At the same time the extension was projected by the government for the first period, so in 35 Meiji (1902) the government started to construct a new railway between Fukuchiyama and Shin-Maizuru (which is a new town coming into existence as a result of the establishment of the naval station), where the naval arsenal works are located, a

${ }^{1}$ Law No. 5, issued in June, 25 Meiji (1892). 
distance of twenty-four miles and eight chains. The work was especially hastened during the Russo-Japanese War, and was completed in October, 37 Meiji (I904), and the road leased to the Hankaku Railway Co. on November 3 of the same year, and thus the railway was run to Maizuru by the company. In 40 Meiji (I907), on August I, both the Hankaku and the Kyoto Railway Companies were bought by the government, and soon after the line from Kyoto to ShinMaizuru was completed by the connection of a newly-extended line with the old one (connecting Fukuchiyama and Maizuru) at Ayabe. The completion of this railway, at least its rapid completion, also owes its development mainly to the military as well as economic condition with regard to the Maizuru Naval Port and the Naval Arsenal there, causing increase of population, especially of officials and workmen taking charge in the arsenal, the gathering of industrial goods needed by the arsenal from all quarters, the development of means of conveyance and the prosperity of the newly erected towns, ShinMaizuru and Amarube.

\section{Water Carriage}

The goods required for the factories of the army and the navy are mostly large, heavy and bulky, and are numerous in quantity. The establishment of these factories has therefore caused an increase of the number of ship lines and voyages both at home and abroad. This is especially true of ocean lines. The European, North American and Australian lines, for instance, have ever since the beginning of Meiji been kept busy importing the large amount of goods needed in military industry, and as a result shipping and communication over those routes have been developed, perhaps in no small degree. As the shipping of the goods of military industry is not carried on by any special steamship service, it is not easy to point out all of the individual cases of such development. This difficulty is met not only with regard to the shipping over foreign lines, but also in the case of domestic shipping where a line has so many relations that it does not admit of a trip being kept 
for the shipping of military goods separately from others. Therefore, in examining the influence which military industry has had upon water carriage, we shall be satisfied with stating only such facts as are easily distinguishable from general shipping, as was the case with land carriage in the previous section.

Among army industries, the wool and the olein oil used in the Senju Woolen Cloth Factory are needed in great quantities, and were mostly imported from Australia. It is this that opened a line to that country some twenty or thirty years ago when no Japanese ship had yet traversed those waters. The progress now seen of the shipping and communication between the two countries is largely attributable to the woolen industry of the Senju factory.

Besides, the transportation of the great variety of materials for munition manufacture in the Tokyo and Osaka Arsenals which was purchased in the past from various countries (England, the United States, Germany, France, Holland and others) in enormous quantities every year, caused ships to ply between those countries and Yokobama, Kobe and Nagasaki, and thus served, probably as much as the Senju Woolen Cloth Factory served for the Australian line, to develop the communication between Japan and those Western countries.

The two cases above refer to the foreign lines of water carriage. The domestic lines at the same time owe much of their development to the army industries. Heavy and bulky home-produced materials, such as metals, ores, timber, provisions, coal, hides, leather, fur, cotton cloth, hemp and hemp cloth are carried in great abundance to the places where the factories are located, or goods manufactured thereof are distributed to garrisons from there. It helped to develop water carriage in many cases between the places producing those raw materials and the places where the army factories are, between the sites of the various factories themselves, or between the sites of the factories and the places where garrisons are located. And it helped the progress of shipping between the ports or harbors near those places. This is explained by the relation the port of Yokohama has with the Tokyo Arsenal, or the ports 
of Osaka and Kobe with the Osaka Arsenal. The Formosan, Korean and Kantoshu steamship lines are also largely indebted for their development to the shipping of the industrial goods of the army.

The naval industries are not behind the army industries in the importation of foreign articles. No small number of foreign and Japanese ships have in the past found service in bringing naval goods here from foreign countries. To these importations of military industrial goods is largely due the establishment and development of the new foreign lines in the early years of Meiji. Especially is it indebted to the bringing over of the war vessels built in foreign countries and importation of machinery, tools, materials, etc., bought in connection with the building and repairing of warships. Such importation of foreign materials is still made, and is benefiting Japan's shipping interest not a little.

The influence exerted upon the domestic shipping by the naval industries can be shown more precisely than in the case of the army industries. The following states this briefly for each of the different naval ports and ports concerned:

Port of Yokosuka.-Yokosuka, situated as it is on the Bay of Tokyo and with its fishing population, had from olden times its fishing boats plying between it and Edo (formerly Tokyo). It also early entered into communication by water with several places on the coast of the peninsula of Miura and with Awa and Kazusa Provinces by the passage of fishing boats and fuel-carrying vessels. Beyond this, however, there were no vessels of any kind of passenger or general freight services, regular or irregular, existing in connection with this place; a thing quite natural with the then poor hamlets of thin population where farming and fishing were the principal living and almost no commerce or industry existed. On the contrary, the Port of Uraga, which was a neighbor of Yokosuka, was in those days considered a good harborage on the Pacific, and it was customary for many of the ships en route to and from Edo to call there for water and fuel or to take refuge there from the heavy seas; in addition to this, the place was flourishing with 
commerce, being one of the accepted centers in Tokaido (a section along the eastern coast of Japan, consisting of several provinces), and was always thronged by merchant vessels, which advanced its shipping superiority. There was a regular service of Japanese boats running once a day between there and Edo, which was largely patronized by the people living near Yokosuka. However, dawn came upon that fishing village when during the Keio Era (I865-I867) the Shogunate established iron works there, and the place began to be alive with the coming and going of the officers and workmen and their families.

After the Restoration of Meiji, there took place in Yokosuka, one after another, an enlargement of the iron works, the change of the same iron works into the Yokosuka Dockyard, and the establishment of a naval station, and with it the place, which was now developing into a town, enjoyed remarkable expansion, and its means of water communication became gradually perfected. The development of the water communication of Yokosuka during those times may be briefly stated as follows: When in I Keio (I 865) the Tokugawa Government established iron works in Yokosuka and a workshop in Yokohama, the iron works commenced navigation by a small steamer three times a week between Yokosuka and Yokohama, and this was the pioneer in the regular steamship service in Japan. This ship was a boat chartered from the government and allowed none but officers of the iron works and their attendants to go on board. Since I Meiji (I868), however, anyone has been permitted to do so. This service was, in 8 Meiji (I875), suspended for a time, but in I3 Meiji (I880) four small ships were loaned to the people by the Yokosuka Dockyard, and were made to carry on a private service, which was doubtless the first steamship service at Yokosuka ever planned by private individuals. The landing place for those steamers, owing to the strict limitations on the coming and going of ships to and from the naval port because of the necessity of keeping military secrets, was compelled to change its location in the I8th year of Meiji (I885), and at the same 
time the manager of the steamship service returned the vessels loaned by the government and continued his service with two newly-built ships of his own. When in June, 22 Meiji (1889) the Yokosuka Branch of the Tokaido Railway Line was opened, the passengers by steamer so diminished that it was necessary to discontinue that steamship service for a time and to use ships of Japanese type in their place.

In the next year the steamship service was revived again, and in the same year a new rival steamship service was begun on the same line, and this competition was continued until the Sino-Japanese War; but since that war navigation on this line has been monopolized by the Teikimaru Steamship Company. This voyage was a direct one, running fourteen miles from Yokohama to Yokosuka, calling at no port on the way. Besides this, there are the Tokyo Line, the Awa Line, the Uraga Line, the Misaki Line, etc., all of which were, like the Yokosuka Line, newly opened after the naval factory had been erected at Yokosuka, and took similar courses as the Yokosuka Line in their commencement as well as development. Among them the line to Tokyo was navigated by the regular liners of the Tokyo Bay Steamship Company and the Miura Cooperative Steamship Company; the line to Tateyama in Awa Province, by the Tokyo Bay Steamship Company; the line to Uraga, by the same company and the Miura Cooperative Steamship Company; the line to Misaki, by the Miura Cooperative Steamship Company. Although there were many changes during the history of these services from their starting to the present, all the services have one common feature in the fact that their development to the present prosperity is a fruit of the naval industry planted in Yokosuka. And on the other hand, the appropriation of the coast of the port to the naval use, as a result of the expansion of the naval station, and the increasing strictness of the restriction against ships entering or leaving the port, although it caused some inconvenience in the use of harbors, etc., never prevented the progress of navigation. In addition to this, to be sure, the busy running of privately-owned vessels shipping cargo relating to the naval industry benefited navigation a great deal. 
Port of Kure.-The predecessors of the city of Kure were Shoyamada, Washo and Miyabara villages, including partly farmers and partly fishermen, and facing the Inland Sea. They were merely common farming and fishing villages, having neither historic site nor natural beauty of landscape worthy of consideration, especially no remarkable commerce or industry; therefore in those days before the establishment of the naval station navigation between several places on the coast in the vicinity of the villages, especially the communication with the city of Hiroshima, was entirely done with fishing boats. Two or three years before the establishment of the naval station in 22 Meiji ( I 889), a great number of laborers, merchants and manufacturers assembled, and construction materials, implements, instruments and other goods used in the naval station were brought there chiefly by sea; and as in those days the Sanyo Railway Line had not yet been opened, a number of ships always assembled at the port. The ships were running from Yokohama, Yokosuka, Osaka, Kobe, Onomichi, Hiroshima, Shimonoseki and ports in Sanyodo, Shikoku, Kyushu, etc., to Kure, regularly or irregularly, while sometimes foreign ships entered the port, all of which not only facilitated the transportation to Kure, but greatly benefited the communication to the ports lyinf on every steamship line. But these were only temporary affairs. The goods transported there and laborers diminished as the construction of the naval station was nearing completion. And especially after the opening of the naval station in 22 Meiji ( 1889 ), owing to the limitation on ships going and coming, and to the growing tendency among the merchants, manufacturers and laborers to reside there permanently, which decreased the number of those who left there, as well as owing to the gradual extension of the Sanyo Railway Line, the number of the steamship lines and the times of navigation, the number of ships entering and leaving the port were decreased. But the munitions needed by the naval arsenal in those days were very numerous, while on the other hand, as a result of the expansion of the navy, the scale of the arsenal was enlarged and the town of Kure developed in a remarkable manner, and after all the 
result was that the ships in Kure were not much lessened. Especially, for instance, between Ujina (near Hiroshima) and Kure there was a regular service, several times a day; and other regular services were opened to several ports in the Province of Aki and Bizen and in Shikoku; and in addition to these, Kure became a regular port of call for ships of the Inland Sea service starting from Osaka and Kobe; in short, the water-carriage service was very convenient. Meanwhile, in 27 Meiji (I 894), the Sanyo Railway Line was extended to Hiroshima, and some years after that it was opened to Shimonoseki; in 37 Meiji (1904), the railway from Hiroshima to Kure was completed, all of which resulted in a large decrease of passengers and freight by sea. Moreover, when, afterwards, as a result of the enlargement of the naval port carried out since January, 43 Meiji (I910), the Port of Kawaraishi, the only port in Kure, was prohibited from allowing free entrance of general ships excepting steamers of less than ten registered tons and Japanese ships of less than Ioo koku, the watercarriage service of Kure was dealt such a heavy blow that at the present time there is no regular steamship line to that port. Nowadays the port of Yoshiura, near Kure, as it has an available railway, is used in place of Kure, and the Ujina Line, Shikoku Line, Inland Sea Line and voyages to the neighboring islands are continuing their regular services.

Port of Sasebo.- The Port of Sasebo before the 'establishment of the naval station was a mere fishing hamlet. It had no means of water carriage except the fishing boats for transporting game to seaside markets nearby, nor was there any port of call by any regular steamship running along the coast of Kyushu. When it was made a naval station in 19 Meiji (I 886), many laborers, merchants and manufacturers gathered there from all quarters, while goods needed by the military authorities and the people in general were shipped there in great abundance. Moreover, as in those days the Kyushu Railway Line was not yet opened and transportation was made by sea, there was a large number of newly opened lines to the same port and a great number of ships was to be found there, 
as was stated about the Port of Kure. And similarly to Kure, the establishment of the Sasebo Naval Station in 22 Meiji (I889), and the railway connecting Sogi with Sasebo, which was completed immediately after the opening of the railway between Moji and Sogi on the Kyushu Line in 3I Meiji (I898), had an effect upon the traffic between Sasebo and other ports; and the port was under the restrictions of the Law of Protection of Military Secrets, as it was a naval port as well as in a strategic zone. But the tract of land for the naval station of Sasebo being different from that of Kure, Sasebo was not under as much restriction as Kure, and there were and are many ships entering and leaving. According to the statistics for recent years there were more than 3,000 steamers, more than I, Ooo European sailors and about 3,00o Japanese ships, all of which shows what fine progress the port made.

Port of Maizuru.--The Port of Maizuru, known as a good port in Tango Province, and near the Port of Miyazu, which, enclosing Amano-Hashidate, one of the three most beautiful spots in Japan, has enchanting views, was-not neglected and was called at by almost all the ships that voyaged through the Japan Sea. Trade there was always as prosperous as at Miyazu, so that it was from olden times regarded as one of the most prominent commercial districts in Sanindo, all of which led the port to a marked advancement in water carriage. It enjoyed convenient means of communication, having many lines, not only to famous ports in the Japan Sea, but to several of those as remote as in Kyushu, coasts of the Inland Sea and the neighborhood of Osaka. Although it must, therefore, be certain that, during the period in which arrangements. for the naval station were made, that is to say, from the setting up there of the Temporary Naval Branch in Architecture for the establishment of the naval station in 29 Meiji (I896) to the opening in 34 Meiji (I90I), as well as since then up to the present time, the naval industry which multiplied both the travel of passengers and the traffic of cargoes caused a sudden increase of ships in number, yet there was scarcely a regular ship line newly opened, and in comparison with other naval ports 
the observable effects of the military industry upon this port were very small.

Port of Tokuyama.--In the Port of Tokuyama, Yamaguchi Prefecture, where the Naval Briquette Manufactory is located, since the establishment of the same manufactory in $37 \mathrm{Meiji}$ (I904), there have been always at anchor a number of steamers and Japanese ships gathering Kyushu coal for making briquette from Moji and Wakamatsu, and distributing briquette to all naval ports. Although the scale of the same factory is smaller than that of any other military factory, it needs and produces such heavy substances as coal and briquette, naturally causing a great need of a number of ships as means of transport.

Port of Wakamatsu.-The iron works located in Yawata town, Fukuoka Prefecture, has had the closest connection with the Japanese military industry since its starting, and now is supplying 60 per cent of its manufactures to military factories. Here will be given, therefore, a short description.

Since the factory was set up in 34 Meiji (I90I), iron ore and pig iron for raw material and coal for fuel were annually consumed there in great abundance. Iron ore and pig iron used in the same factory for raw materials during 2 Taisho (I9I3), excepting what was produced from Japan herself, amounted to 200,000 tons of Chinese ore, about I 50,000 tons of Korean ore and about 130,000 tons of pig iron produced in foreign countries except China, while about 80,000 tons of coal produced in Kaiping, China, besides Japanese coal was consumed here. For bringing Chinese iron ore, between the Port of Yawata (generally together with the original Port of Wakamatsu called "the Port of Wakamatsu," because both are situated in the same bay) and Shihhuiyao, China (near Daiya, and therefore generally called also Daiya), a new steamship service was opened, and during eight months yearly, from April to November, about one hundred voyages are made with six or seven steamers of the class of 3,000 tons; while for bringing Korean iron ore there was opened from the coast of the Daidoko River in the vicinity of iron producing places, Inzoku, Sainei 
and Angaku to the Port of Wakamatsu, a service on which three or four steamers of the class from I,500 to 2,000 tons are running every year except during the period of the freezing of the same river, that is to say, for eight months, from April to November, and on the other hand, on a new line between Shinkoto and the Port of Wakamatsu are running three or four steamers of the class of 3,000 tons in the service of bringing coal produced from Kaiping, China.

The principal consumers of the manufactured iron are the military arsenals of Tokyo and Osaka, and the Tokyo Naval Arsenal as well as the other naval arsenals, etc. They are followed by the factories which are connected with the Mitsubishi Dockyard at Nagasaki, the Kawasaki Dockyard at Kobe, factories connected with the military industry, in the neighborhood of Tokyo, Yokohama, Osaka and Kobe, etc. Of course, on the lines between these ports, there is a continual service of steamers; especially between those ports lying on the Inland Sea Line, as Osaka, Kure, Kobe, Tokuyama (from where pitch, a by-product of the Iron Works, is transported to the Tokuyama Briquette Manufactory), etc., are running not a few tugboats.

The service on the above-mentioned lines is performed by steamers of the Japan Mail Steamship Company and of some individuals. Also two steamers owned by the same factory are in service and make several voyages for the factory. Besides, steamers on foreign lines (except the China line) bringing foreign pig iron and other foreign materials needed in the same factory visit the port every month.

Port of Muroran.-About the Nippon Steel Manufactory at Muroran, Hokkaido, as it is the only private concern having the special service of making arms, a short statement will be made.

The steamship line between Muroran where the Nippon Steel Manufactory is located and Aomori was, up to 40 Meiji (1907), carried on by regular steamers of the Japan Mail Steamship Company, and irregular steamers of the Kuribayashi and the Funkawan Steamship Company. In the same 
year, the Nippon Steel Manufactory was established, and since then passengers and cargoes have gradually increased, which has naturally resulted in the increase of the number of voyages and has greatly benefited communication between Honshu (Main Island) and Hokkaido.

For the purpose of transporting the raw materials used and the goods manufactured in the steel manufactory, a steamship line of four steamers from 500 to I, 000 tons, owned by private individuals and hired for transport by contract between them and the steel manufactory, has been opened, running between Muroran and Yokohama, Yokosuka, Osaka, Kobe, Kure, Maizuru, Sasebo, Nagasaki, etc., calling at these ports twice a month.

There are two foreign steamship lines, one of them served by the Japan Mail Steamship Company via Yokohama, and the other direct from foreign countries. The times of voyage are usually twice a month in the former case, and irregular in the latter.

It is to be judged from the outline of the development of navigation as stated above that the military industry not only has affected navigation in Japan so much as to be worthy of special mention in the history of transportation during the era of Meiji, but is still affecting navigation. 


\section{CHAP'TER VII}

\section{SOCIAL EFFECTS}

As has already been seen, the military and navy industries, by greatly affecting all industries within the country, hold an important relation to the national economy. It is easily conceivable, therefore, that it may have important effects upon the national life, i. e., upon production, consumption, labor, prices, income, population, public peace, sanitation, etc. It is a very important matter from the standpoint of economic investigation of the military and naval industries exactly to examine and study what and to what extent is the influence of the same upon the problems of life at the present time. However, it is very hard to give a correct and impartial estimate by actual observation of those effects universally and exactly, because not only has the military and naval industry an extensive relation to many things, but there are a number of complicated questions relating thereto. Of course, it is difficult to examine all those relations in any private investigation, and even public investigations relating to the statistics are so deficient that it leads the writer nearly to despair. And if we, for the sake of simplicity, merely try local observations, we can not form any analogy of the whole, but can be easily carried into error. This is the reason why in this work every factory in every place was adopted as the object of study. The result of the investigation is that the influences of the military and naval industries upon society, though there are some special points in each place, are in general not so different but have many common points, the same or similar, which therefore are described in general in the following sections (under the beadings of Revenue, Labor, Relief Service, Population, and Public Peace and Sanitation), while only those which it is impossible to put together are mentioned separately. 


\section{Revenue}

We can say decidedly that the military and naval industries have a certain effect upon the income of the people at large. How far its effect extends is a question, and if we trace all results, even the indirect and remote ones, there is no visible limit. Hence, our investigation is to be confined to such persons as are directly related to the industry itself and industrial localities; officers taking service in the factories, workmen, merchants in the employ of factories and the owners of land or houses in the places where factories are located, as well as the merchants and manufacturers in the same places. Among these, the income of the officers, as fixed by the organizations, the government, and the ordinance of salary, needs no particular statement. Concerning that of the merchants in the employ of factories and others except the workmen, it is very difficult to make a statement in detail, and even if it were possible regarding certain ones there are no accurate figures to enable us to infer all the circumstances of income. It is necessary, therefore, that, in the following pages, in addition to the outline of the subject, there begiven general remarks on the income of workmen employed in those factories only.

The wages of the workmen in military and naval factories vary, for several reasons. For instance, the average income of a hand for a day in the Tokyo Arsenal is $88 \operatorname{sen}$ (44 cents), Osaka Arsenal 76 sen (38 cents), Military Clothing Department 60 sen (30 cents), Military Provision Department 78 sen (39 cents), Senju Woolen Cloth Factory $52 \operatorname{sen}$ (26 cents), Drawing Section of the Land Survey Department 7 I sen (35.5 cents), Railway Material Department 49 sen (23.5 cents), Yokosuka Naval Arsenal $82 \operatorname{sen}$ (4I cents), Kure Naval Arsenal $76 \mathrm{sen}$ ( 38 cents), Sasebo Naval Arsenal 66 sen (33 cents), Maizuru Naval Arsenal 66 sen (33 cents), Ryojun Dockyard $74 \operatorname{sen}$ (37 cents), Naval Arsenal $67 \operatorname{sen}$ (33.5 cents), Shimose Powder Mill 84 sen ( 42 cents), Repairing Yard of Ominato Secondary Naval Station 6I sen (30.5 cents), Repairing Yard of Bako Secondary Naval Station 60 sen (30 cents), Briquette Manufactory 63 sen (3I.5 cents).

In comparing the various amounts of wages in these factories 
with those of the ordinary workmen living in the place where such factories are located, there is on the average not much difference between them, although in the case of a certain kind of workmen there may be found some differences. But it may be said that the income of ordinary workmen for a month is less than that of those engaged in a military or naval factory; for the latter, who seldom rest from work except on the holidays, get a monthly income for almost a whole month, while the former, who work less days, gain a smaller amount in a month, because they can not always be at work, on account of the weather or the condition of the market. The workmen in the military and naval factories are classified into two kinds, the contract laborers and the ordinary laborers, the former being in service for a fixed term by contract and the latter contracting for no term of service. Of those, the contract laborer is better situated than the ordinary laborer by receiving an allowance of a reasonable sum after the expiration of the term. Besides, there is an ordinance regulating the special allowance for the government workmen and laborers, whereby those who have been injured or have become sick in the public service are cured, or may receive an allowance for retirement. In addition to these, in the case of the naval factories, there is the Workmen's Mutual Relief Association organized for the same purpose. All these favors increase the income of the workmen directly or indirectly by giving extra gain added to the nominal wages and benefit the military and naval workmen more than those in service in any private factory.

The wage of the female hand, who is employed by some military or naval factories in no small numbers, is $36 \operatorname{sen}$ ( 18 cents) per day on an average, which shows an unusually good gain for a woman who is neither well educated nor specially skilled. Moreover, most of these women are of the family of the workmen and so they are enabled by the increased income to cooperate and to live well without anxiety.

In short, the circumstances of the workmen in the military and naval industries, owing to their safe situation, continual service and various special favors, are a little better than those of the ordinary ones. 
To show the income, in the following tables are given the total sums of wages and average amount per capita of wages obtained by the workmen in service in each of the military and naval factories.

Wages of Workmen in Military Arsenals

\begin{tabular}{|c|c|c|c|c|c|}
\hline \multirow{2}{*}{ Factories } & \multirow{2}{*}{$\begin{array}{l}\text { Total } \\
\text { Sum of } \\
\text { Wages }\end{array}$} & \multirow{2}{*}{$\begin{array}{l}\text { Working } \\
\text { Number of } \\
\text { Workmen }\end{array}$} & \multicolumn{2}{|c|}{$\begin{array}{c}\text { Average Daily Wages } \\
\text { per Workman }\end{array}$} & \multirow{2}{*}{$\begin{array}{l}\text { Number of } \\
\text { Workmen }\end{array}$} \\
\hline & & & Male & Female & \\
\hline & Yen & & Yen & $Y e$ & \\
\hline Tokyo Arsenal. & $3,898,732$ & $4,880,335$ & o. & $0.4 \mathrm{I}$ & I 7,367 \\
\hline Osaka Arsenal...... & $2,435,749$ & $3,327,869$ & 0.76 & 0.33 & 10,480 \\
\hline Military Clothing De- & & & & & \\
\hline $\begin{array}{l}\text { partment .... } \\
\text { Military Prov }\end{array}$ & 371,023 & 865,553 & 0.60 & 0.32 & $2,53 \mathrm{I}$ \\
\hline Department....... & 69,800 & $\mathbf{1} 57,926$ & 0.78 & 0.26 & 575 \\
\hline $\begin{array}{l}\text { Senju Woolen Cloth } \\
\text { Factory ........ }\end{array}$ & 148,364 & $36 \mathrm{I}, \mathrm{I} 76$ & 0.52 & 0.30 & J 078 \\
\hline Drawing Section of & & & & 0.50 & 1,070 \\
\hline $\begin{array}{l}\text { the Land Survey } \\
\text { Department...... }\end{array}$ & 909 & $\mathrm{I}, 278$ & $0.7 \mathrm{I}$ & & 4 \\
\hline Railway Material De- & & & & & 4 \\
\hline partment.. & 16,473 & 33,608 & 0.49 & .. & 108 \\
\hline Total. . & $6,94 \mathrm{I}, 050$ & $9,627,745$ & 0.80 & 0.36 & 32,143 \\
\hline
\end{tabular}

Wages of Workmen in Naval Arsenals ${ }^{1}$

\begin{tabular}{|c|c|c|c|c|c|}
\hline Factories & $\begin{array}{l}\text { Total } \\
\text { Sum of } \\
\text { Wages }\end{array}$ & $\begin{array}{l}\text { Working } \\
\text { Number of } \\
\text { Workmen }\end{array}$ & $\begin{array}{c}\text { Average } \\
\text { Daily } \\
\text { Wages } \\
\text { of a } \\
\text { Hand }\end{array}$ & $\begin{array}{c}\text { Average } \\
\text { Monthly } \\
\text { Income } \\
\text { of a } \\
\text { Hand }\end{array}$ & $\begin{array}{c}\text { Number } \\
\text { of } \\
\text { Workmen }\end{array}$ \\
\hline & $Y e$ & & $Y$ & $Y e$ & \\
\hline $\begin{array}{l}\text { Yokosuka Naval } \\
\text { Kure Naval Arse }\end{array}$ & $\begin{array}{l}2,567,398 \\
6, \mathrm{I} 4465\end{array}$ & & & & $\begin{array}{r}8,686 \\
22,245\end{array}$ \\
\hline sebo Nav & 1,242 & 1,79 & $\begin{array}{l}0.751 \\
0.692\end{array}$ & $\begin{array}{l}22.907 \\
19.185\end{array}$ & $\begin{array}{l}2,245 \\
5,396\end{array}$ \\
\hline 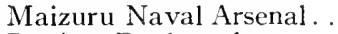 & 987 & 1,3 & 0.741 & 19.662 & 4,184 \\
\hline Ryo & $368, \mathrm{C}$ & 769 & 0.715 & 21.179 & $1,44^{8}$ \\
\hline Shi & & & & 25 . & 262 \\
\hline Nav & 46,862 & 76,567 & $0.6 \mathrm{I} 2$ & 19.924 & 196 \\
\hline $\begin{array}{l}\text { Secondary NavalStation } \\
\text { Repairing Yard of Bako }\end{array}$ & 39,740 & $60,99 \mathrm{I}$ & $0.65 \mathrm{I}$ & I 8.297 & 181 \\
\hline Secondar & 37 & & o & I 7 & 173 \\
\hline Briquette Manufactor & 45 , & 82,579 & $0.55^{6}$ & I 8.880 & 212 \\
\hline & I I $, 528,432$ & $15,513,279$ & 0.743 & 22.351 & 42,983 \\
\hline
\end{tabular}

${ }^{1}$ First financial year of Taisho. 


\section{LABOR}

The labor question will be treated by dividing it into two parts-."employment" and "condition of life."

Employment by the military as well as the naval factory is obtained on the basis of fixed, but, speaking generally, lenient qualifications. The way of collecting the workmen is as follows: At first, an invitation is given, and anyone qualified may apply; then theapplicants are subjected to a physical examination, and those who have passed it are divided into two classes. One class consisting of a certain number needed by the factory and recognized to be competent after an examination of their social position, are adopted as apprentices, and after training for a fixed term and an examination are promoted to the position of ordinary workmen. The other class consists of a certain number from the beginning adopted after a technical examination as proper workmen supplied with reasonable daily wages. The policy in adopting the workmen is to prefer such as live in the same place or in the vicinity of the place where the factory is built, or in the family of a workman already in employ, and so there are but few "journeymen," who are found in abundance among the coal miners and the like. Although such a method as stated above with regard to selection sometimes makes entrance in to the service more difficult, in comparison with the general laborers, the military and naval factory, by its great receiving capacity, prevents a surplus of general labor in localities, by giving them suitable work. Especially, some factories employ numerous girls, and giving them work suitable to their strength and health enable them to escape from the adversity which wcmen living in the city and having small jobs or no work meet, with a result which is to be seen in any factory in any place.

As to the condition of life of workmen, common to most of the places having military and naval factories, some of them live in the town where the factories are located, and some of them are dwelling in the villages in the suburb of the city. Those who reside about the boundary line between the town and the suburb do not pay much less rent compared with those 
dwelling in the town for land and house, etc., but their disbursements for those purposes diminish in proportion as their residences are far from the town. Why do they not live in the suburb where rents as well as food and all commodities are so much cheaper that they can live in comfort, but deliberately prefer the town? Perhaps the answer may be that, besides some reasons with regard to their family, the pressure upon their life is not so heavy that they can not endure the city life.

According to statistics, 32 per cent of all the workmen are living in the same house with their protector, more than 12 per cent are lodging, and those who have their own houses are only a little over 55 per cent, which shows how hard it is to live independently by means of the income from labor. However, such conditions can not be said for certain to be due to adversity, if we note the fact that most of those living in another's house are female hands. On the other hand, of the more than 76 per cent of male hands, more than 66 per cent are house owners, and less than Io per cent are living in another's house, though the conditions vary according to age, the number in the family, etc. Speaking generally, they have income enough to live independently, or are living in comfort in dependence upon the home where they live; in short, they are scarcely suffering adversity in life. Of those who are lodging and number more than 23 per cent of the whole, about 70 per cent have incomes over I2 yen $(\$ 6)$ per month, while about 30 per cent have incomes under 12 yen. And as most of them, young and unmarried, may be supposed to need $8-8.50$ yen (\$4-\$4.25) monthly for the charge of lodging, those who have incomes over I 2 yen $(\$ 6)$ may be said not to be suffering from poverty, while only the others seem to be poor. As to the female hands, most of those keeping no home are perhaps living in the same house with their husbands, fathers, brothers, etc., and so must not be suffering much. According to the latest examinations, even the female hands listed as "keeping house," who have an income of only 8.70-15 yen $\left(\$ 4.35^{-}\right.$ $\$ 7.50$ ), in fact rarely rent a room, so that the expense for living is not much more than that of those who are lodging. The 
female hands who have small incomes and are living in lodging houses, to be sure, must be suffering from adversity, because the expense for lodging is from $6.5^{0-7}$ yen $\left(\$ 3.25^{-}\right.$ $\$ 3.50$ ) on the average.

The maximum, minimum and average of the amounts of wages for a month gained by the workmen are shown as follows:

Classification by Age of Workmen

\begin{tabular}{|c|c|c|c|c|c|c|}
\hline \multirow{2}{*}{ Workmen } & \multicolumn{3}{|c|}{ Male } & \multicolumn{3}{|c|}{ Female } \\
\hline & Maximum & Minimum & Average & Maximum & Minimum & Average \\
\hline $\begin{array}{l}\text { Mino } \\
\text { Majo }\end{array}$ & $\begin{array}{l}Y e n \\
\text { II. } 400\end{array}$ & $\begin{array}{l}\text { Yen } \\
8.100\end{array}$ & $\begin{array}{c}\text { Yen } \\
8.750\end{array}$ & $\begin{array}{l}\text { Yen } \\
6.300\end{array}$ & $\begin{array}{l}\text { Yen } \\
+.800\end{array}$ & $\begin{array}{l}\text { Yen } \\
5 \cdot 700\end{array}$ \\
\hline Thi & 75.000 & 9.600 & 18.200 & I 5.100 & 6.600 & II + IO \\
\hline
\end{tabular}

\section{Relief Service}

In the following pages the relief service of both the army and the navy is described.

\section{The Army}

As the relief services of every military factory are not very different from each other, the services of only the two arsenals, Tokyo and Osaka, are mentioned.

For injured and sick workmen, the following officers are provided:

Tokyo Arsenal: One colonel or major, eight captains or lieutenants, and seven noncommissioned officers of the army medical corps.

Osaka Arsenal: One colonel or major, six captains or lieutenants, and five noncommissioned officers of the army medical corps.

These officers are to treat the injured and diseased of the officials and workmen in the arsenals, the expenditure for treatment being paid out of the working expense, if the injury or disease be caused by any official business, or if caused in any other way, consultation and prescription only are given 
and the charge for medicines paid by themselves. The statistics for the former are as follows:

Medical Treatment of Employees of Arsenals

\begin{tabular}{|c|c|c|c|}
\hline \multirow{2}{*}{ Fiscal Years } & \multirow{2}{*}{$\begin{array}{l}\text { Number of } \\
\text { Persons at } \\
\text { End of Year }\end{array}$} & \multicolumn{2}{|c|}{ Expense for Treatment } \\
\hline & & $\begin{array}{l}\text { Amount } \\
\text { (Actual) }\end{array}$ & $\begin{array}{c}\text { Average } \\
\text { Per Capita }\end{array}$ \\
\hline $\begin{array}{ccc}42 & \text { Meiji } & \text { (I909) } \ldots \ldots \\
43 & \text { " } & \text { (I910) } \ldots \ldots \\
44 & \text { (I9I }) \ldots \ldots \\
\text { I Taisho } & \text { (I9I2) } \ldots \ldots\end{array}$ & $\begin{array}{l}0.426 \\
0.405 \\
0.484 \\
0.460\end{array}$ & $\begin{array}{c}\text { Yen } \\
\text { 10,916 } \\
9,764 \\
12,389 \\
13,330\end{array}$ & $\begin{array}{c}Y e n \\
25,588 \\
24,058 \\
25,578 \\
28,937\end{array}$ \\
\hline
\end{tabular}

But the small number of health officers stated above being insufficient for satisfactory results, the workmen established hospitals by their private means, where the treatment of themselves and their families is performed under the supervision of the chief superintendent of the arsenal and at their own expense for the actual charge for medicines.

As for the relief of workmen in the arsenal, determined by Imperial Ordinance No. 86, ${ }^{1}$ enacted in 40 Meiji (I907), the treatment charge, relief allowance, allowance for the crippled or disabled, special allowance, funeral expenses, etc., are given, while besides the workmen who have served for a certain term may receive, by the Ordinance of Help for the Workmen in the Arsenal, a life annuity or the grant of a lump sum, if they retire.

Besides, private corporations are organized by the public contributions of the officials and workmen, and under the supervision of the chief superintendent, for mutual relief. But as there are found some unsatisfactory points in this system, there is in course of organization a mutual relief association, to unite all of the military workmen.

\section{The Navy}

From the establishment of the naval factories to 35 Meiji (I902), only relief as follows, by the Ordinance of Help for the

${ }^{1}$ Ordinance of Special Allowance for the Government Workmen and Laborers. 
Government Workmen and Laborers, has been made for the dead or injured:

(a) To the survivors of those who die from injury are given funeral expense from io yen to I 5 yen and the special allowance from 80 days' to I 50 days' wages.

(b) To the injured are given Allowances for the Crippled or Disabled, according to the following classification:

I. To those entirely disabled for life: from I20 to I 70 days' wages.

2. To those disabled from their work or service for life: from 60 to I 40 days' wages.

3. To others, crippled or disabled: from $5^{0}$ to Ioo days' wages.

(c) To the injured, but not crippled or disabled, are given allowances according to the following classification:

I. To those retiring from work, whose treatment is estimated to need some months: from 30 to $5^{\circ}$ days' wages.

2. To those retiring from work for treatment: from onethird to one-half day's wages.

(d) To those not injured enough to receive either the Allowance for the Crippled or Disabled, or the allowance shown in the preceding clause, yet needing treatment (limited only to those not being treated at the government expense), are given the actual expense for treatment.

What is stated above shows the relief practiced by the government for the injured or diseased workmen and laborers employed. But the ordinance provides several strict limitations, and so the aid seems too deficient to help the poor laborers, who have no money capital but merely the physical one. This is the reason why, in 35 Meiji (I902), the Workmen's Mutual Relief Association was organized, by which a hospital was prepared and a new service was opened in addition to the Ordinance of Help for the Government Workmen and Laborers. Although there are some differences of terms of agreements relating to the organization and the manner of relief in associations within the circle of every factory, (I) the admission of the injured workmen into the hospital and (2) the allowance to be given to survivors of the injured are common to all. 
The Workmen's Mutual Relief Associations, which have been established in every arsenal for the purpose of perfecting the relief of the workmen, together with the Ordinance of Allowance for the Government Workmen and Laborers, are different in their organization and operation; accordingly, the fee and the means of relief are diverse, because the resources of the same association are entirely obtainable from the contributions of the workmen themselves and their friends. But as a uniform means of relief service common to the circle of the one and same office was recognized to be an urgent necessity, the Naval Mutual Relief Association, still in existence, was organized by Imperial Ordinance No. I 8, issued on March 22, 45 Meiji (I9I2).

Of several services of the Naval Mutual Relief Associations, those given to the injured, to the survivors of those who have died from injury, and to those who are ill from injury, are as follows:

All these cases are divided into five classes according to the degree of the injury and the sickness, with varying allowances as follows:

First Class, to the survivors of those who have died from injury: from 2 years and 3 months' to 2 years and 6 months' wages.

Second Class, to those who have lost their sight or have been crippled in 2 or more than 2 limbs and disabled from active work during life, or other cases corresponding to the above: from 2 years' to 2 years and 6 months' wages.

Third Class, to those crippled in one limb and, though able to do their own business, disabled from service for life, or other cases corresponding to the above: from I year and 2 months' to I year and 6 months' wages.

Fourth Class, to those who, though able to do their own business or the service, are incurably injured and thereby discharged: from 6 months' to I year's wages.

Fifth Class, to those who, though incurably injured, are able to continue their service: from I month's to 6 months' wages.

In the case of the first class, besides the above-stated allow- 
ance for the injured and diseased, allowances in the case of death, as shown in the following, are given in accordance with the time they have been in service.

To those who have served less than I year: 90 days' wages.

To those who have served I-2 years: 105 days' wages.

To those who have served 2-3 years: 120 days' wages.

To those who have served more than 3 years, the allowance is increased by I 5 days' wages per each additional year of service.

The injured or sick, except those of the first class, are treated at government expense in certain hospitals, and during such periods, or those periods in which they are resting from work on account of treatment (excepting public holidays) are, it is ordained, to be supplied with half of the daily wages.

It goes without saying that the Ordinance of Allowance for the Government Workmen and Laborers is not applied to those granted the above-mentioned allowance for the injured or sick.

There were 369 injured ( 29 of whom died) who were assisted by naval offices during the first year of Taisho (I9I2), while the number of men relieved by the Mutual Relief Association, and the expense therefor, from 42 Meiji (I909) to I Taisho (I9I2), were as follows:

Year

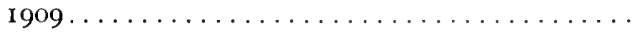

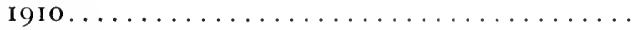

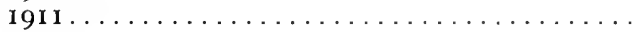

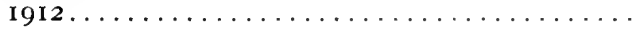

Men

27,926

29,93 I

32,072

33,441 $\underset{\text { Expense }}{\text { Yen }}$

I 6,066

60,310

90,195

132,500

\section{Pofulation}

It is evident that the existence of any military factory affects the increase or decrease of population in the neighborhood of the place where it is situated. But the rate of increase or decrease may not be exactly inferred from the condition of such great cities as Tokyo or Osaka, where the considerations involved are not absolute, but relative, because in those cities there may be many factories causing the change of population. This is the reason why, to make a more significant investiga- 
tion, towns having relation only to the military industry and no other complicated circumstances, such as the newly opened naval ports of Yokosuka, Kure, Sasebo and Maizuru, are to be preferred for the same purpose. This is the method that is adopted in the following pages in showing the fluctuation of population in each town separately.

(I) Yokosuka, formerly consisting of Yokosuka Village, a half farming and half fishing community, and six other hamlets, gradually became prosperous after the repairing yard had been set up there by the Shogunate in I Gwanji (r864); about 2 Meiji (I 869), the damp marshes covered by thick bushes were filled in; about 4 Meiji (187I), further reclamation was accomplished on part of the coast, and thereby, at last, it showed a resemblance to a small town.

After the establishment of the Yokosuka Dockyard in 5 Meiji (1872) its population was gradually increased, and yet, according to the investigations in March, 12 Meiji (1879), there were only I,407 houses and 3,422 men. In I7 Meiji (1884), the naval station was removed there from Yokohama; then, in May, 22 Meiji (1889), the Yokosuka Dockyardwas renamed the Shipbuilding Branch of the Yokosuka Naval Station, when, in accordance with the expansion of shipbuilding work, workmen, merchants and manufacturers and whoever was connected therewith moved there. This naturally resulted in expansion and the increase of houses and population. When the Sino-Japanese War broke out in 27 Meiji (1894), workmen were in great demand, owing to sudden increase of work in building and repairing ships; and when that war came to a conclusion and, as a result of the completed expansion of armament after the war, the officials and workmen were more and more multiplied, the circumstances of the town were completely changed. The war with Russia during 37-38 Meiji (I9041905) necessitated building big battleships, and caused a further enlargement of the scale of the dockyard and the multiplication of officials, workmen, merchants, manufacturers, so that the town was brought at last to a municipal organization in 40 Meiji (1907). Since then the houses and population of 
the city have annually increased until it reached, according to the investigation made at the end of I Taisho (I9I2), I2,695 houses and 70,210 inhabitants, and at the present time it is said to have a round 80,000 .

It is easy to understand how much importance the military industry has had in causing the progress of any city or town from the fact that even such an insignificant village as Yokosuka, half fishing and half farming, having no factor to make the town prosperous, has developed up to its present condition because of being selected as the site for the naval factory.

(II) On the site where the city of Kure now stands there had been three fishing and farming villages before the naval port was founded there. The establishment of the naval station in 22 Meiji ( 1889 ) must be said to be the origin of the city of Kure, for, upon the opening of the naval office, a large number of merchants, manufacturers and laborers suddenly moved there, so that at the end of the same year, a small poor village was changed to a splendid town having more than 2,000 houses and over 10,000 inhabitants. When the SinoJapanese War broke out in 27 Meiji (I894), the entrance of ships into the port as well as building and repairing being increased, workmen assembled there in large numbers, and the circumstances of the town were completely altered. In the next year the war was over and as a result of the enlargement of naval construction the scale of the Kure Naval Arsenal was still more extended, making the trade and manufacture of the town more and more thriving, until at last it was organized as a municipality having more than 13 , Ooo houses and more than 72,000 inhabitants. Tliereafter, following the advancement of the military industry, there was a continuous increase of the population, and when the war in 37 Meiji (I904) broke out, the arsenal was very busy both day and night by multiplying the workmen, which naturally resulted in the prosperity and the constant development of the city. Peace was restored in 38 Meiji (I905), and the necessity of building large warships having been demonstrated by the war, the naval arsenal was again enlarged, and the largest dock, 
able to make with ease a ship of 30,000 tons, to realize the significance of the phrase "head of the naval industrial place in the Orient," was constructed. Accordingly, the city quite changed its appearance, and merchants, manufacturers and workmen crowded there in haste, so that the number of houses and inhabitants, according to the investigation made at the end of $4 \mathrm{I}$ Meiji (I908) were 2I,676 and 98,70I, respectively. The annual development of the city and the increase of its population in accordance with the advancement of the military industry was so marked that it had 25,030 houses and I 5,697 inhabitants at the end of 44 Meiji (I9I I), and at the present time it stands at the head of all the Japanese ports, having 125,000 inhabitants, about 90 per cent of whom consist of officials and workmen connected with the naval arsenal, and small manufacturers, merchants dealing in the goods demanded by the arsenal, as well as their families. It must be the result of the military industry that Kure became such a large city before thirty years had elapsed since the opening of the port; in a word, the development of the military industry has, to be sure, greatly affected that of the city itself.

(III) The present city of Sasebo had been, before the naval port was founded there, merely a desolate fishing hamlet situated in an obscure spot of Kyushu, and having only 800 houses about I2 Meiji (I879). When it was decided to set up a naval station in I9 Meiji ( 1886 ), and construction was begun, a great many merchants, manufacturers and laborers assembled from all quarters, with the result that many lots of land were cleared and a number of houses were built, until there was formed a small town. In 22 Meiji (I889), the construction of the naval station was entirely completed, and it was opened in June. Even at the end of the same year the town had more than 1,500 houses and more than 9,800 inhabitants. When the Sino-Japanese War broke out in 27 Meiji (I894), vessels of all kinds entered and left the port in large numbers, while travelers, public and private, passed by in uninterrupted succession, so that there was wonderful activity and prosperity beyond the power of language to 
describe. The result was that trade grew very brisk and the condition of the city was quite changed.

After the war, the amount of goods demanded by the arsenal kept parallel with the enlargement of its scale, which led the town into such a prosperous condition that, after 32 Meiji (I899), 80o to I,0oo houses were built annually; and yet the demand was not sufficiently met. Thus the expansion of the town continued until it grew into a large city, and in April, 35 Meiji (I902), was organized as a municipality, having then more than 8,300 houses and about 50,900 inhabitants.

Then the Russo-Japanese War began, and the naval industry was at the acme of its busiest condition on account of the construction, repairing, etc., of warships. There was a wonderful crowd of merchants, manufacturers and laborers; and the figures of the investigation made at the end of 38 Meiji (1905), of 13,606 houses and 70,703 inhabitants, tell us how the town made a sudden increase in population.

The multiplication of the workmen employed there, keeping pace with the enlargement of the scale of the arsenal after the Russo-Japanese IVar, made the trade and industry more prosperous. It was found at the end of $44 \mathrm{Meiji}$ (I9I I) to have had 12,755 houses and 86,409 inhabitants, and even now such an increase is continuing. In short, the advancement of this town is, no doubt, as in the case of Yokosuka and Kure, mainly due to the fact that it was made a site of the naval industry.

(IV) The naval port Maizuru consists of two towns, ShinMaizuru and Amarube, both of which, before the establishment of the naval port, were humble ham'ets facing the northern sea, and inhabited by farmers and fishermen. Upon the opening of the Maizuru Naval Station in October, $3+$ Meiji (I9OI), the population suddenly increased; and after the RussoJapanese War, owing to the busy work of the military industry, which resulted in an increase of workmen and consequently the development of trade and industry, the city grew more and more flourishing, so that even in 39 Meiji (I906) it had more than 4,000 houses and over I 4,ooo inhabitants. The perfect 
arrangement of the same port afterward caused a greater activity of the naval industry and a gradual increase of houses and population, so that, finally, last year, the houses and inhabitants numbered over 5,800 and 23,500 , respectively.

Although this town, because of its youth and smaller scale, compared with other naval ports, had no population, suddenly increased like the above stated ports, yet a greater development for the future is to be expected, judging from the increase of population which is still going as before. The answer to the question, why the town has such a good condition in the present and future is, "the development of the naval industry," which testifies, in fact, how the military industry is able to encourage the expansion of any place.

Many instances are given above, showing the fluctuation of population at any place where a naval factory is set up. The same instances are found at the places where the military industry is carried on. They are in the neighborhood of Tokyo, the woolen cloth factory in Minami Senju, the ammunition factory in the neighborhood of $\mathrm{Oji}$ and Itabashi, in the country, the influence of the arms factory at Atsuta (Aichi prefecture), etc., upon the vicinity whereby it was changed to a flourishing town; all these are actual instances manifestly showing the fact that every military factory has contributed to the development of the locality where it is situated.

\section{Public Peace and Sanitation}

The workmen engaged in the military or naval factories are being selected from the natives, mostly those who were honest and good being educated in their homes under the control of father or brother. Moreover, when they are adopted, their social positions are minutely examined by ordering them to present a certificate from a public officer, or by direct inquiry regarding the same matter at the public office. Anyone who is of bad character, or has been condemned for a crime, is rejected, while those who conduct themselves irregularly after they have been taken in are dismissed without hesitation, and thus the public morality is maintained. Because, in addition 
to this, the fostering of morality at large, as well as the idea of public duty, regularity, and cooperation, indispensable to workmen engaging in the military industry, is diligently developed, there is reason to believe that all workmen in the military service, even when they are outside of the factory, have a better effect upon the public peace and popular morals, compared with the ordinary workmen not trained and not self-restrained. Moreover, owing to the fact that there is no perfect trade union like those of European countries to be found in Japan, and that it is rather a characteristic of the Japanese workman not to have the spirit of insubordination to his employer, any riot such as a strike has never been carried out, and so the control of the public peace is very easy. Again, no real strike has been carried out by the military or naval factory since the Restoration of Meiji, although some time ago, in the Tokyo Arsenal, in the case of the army, and in the Kure Naval Arsenal, in the case of the navy, a part of the workmen, presenting a certain request, acted as if preparing for a strike, but this move was immediately checked. From this fact it is to be inferred in what satisfactory circumstances, not likely to disturb the public peace, are the Japanese military factories.

As to sanitation, all the military and naval factories have military surgeons under their exclusive control; and they are in charge of the maintenance of the daily health of the workmen, consultation and treatment of the patients, and several other services. Medical examination and lectures on hygiene are given regularly or irregularly, while at the time of the prevalence of infectious diseases, methods of prevention are devised; especially when there is an epidemic of smallpox, vaccination is strictly enforced upon all the workmen-all of which contributes successfully to diffusing the idea of sanitation in private as well as in public. In short, the workmen engaged in the military service are, as they are put under the strictest care for sanitation and protection against infectious diseases while they live in the factory, far different, in their care of sanitation, from other workmen, who, being in want of sanitary ideas, cause disturbance to sanitation within and without 
the factory; and thus even when military workmen are outside of the factory, in their home or native places, they will have a good influence upon the public. All these effects influencing sanitation at large must be said to be a valuable contribution of the military industry. 


\section{CHAPTER VIII}

\section{CONCLUSION}

The view of the influences of the military industry upon the national economy of Japan is substantially as stated above. At the present time, there are 28 factories, both military and naval, employing 75,000 workmen and spending an enormous sum of money-about 80 to 90 million yen during the latest fiscal year. It is a matter of course that such a great industry should have an important effect upon all the industries in Japan and consequently is producing marked results upon the national life. The policy and administration of the military industry in any state is actually a great problem upon which depends the fate of the state; that is to say, in case it should happen that the policy is mistaken or the administration is not proper, the country might hardly maintain its position not only from the military, but also from the financial and the economic points of view. Although the policy which the Japanese Empire has adopted for military industry since the Restoration of Meiji is, like the program of the general national defense, not free from the criticism that it has had a tendency toward too rapid progress, compared with the financial and economic condition of Japan, the military industry, being rather opportunely administered, and the whole nation's effort being added, has met satisfactorily the demands in war and has made her an honorable victor in every conflict. Moreover, as already stated, leading, protecting or encouraging continuously the related industries and means of communication, especially several industries of the people, it has in no small degree promoted their advancement. Most of the achievements which raised the Japanese industries, especially the manufacturing industry, as high as their present position at one bound within fifty years after the Restoration, are due to no other than the military industry. It is a fact that, observed 
from past results, it occupies an important part of the expenditures for national defense, and a large amount has been paid in its administration which disturbed the financial and economic equilibrium of the country, so that it seemed as if she made partial development in the military line only. At the same time, however, it is an indisputable fact that other government and private industries, being led and guided by military industry, continuously advancing by rushes, shortened the term needed for their development. These are not all of the effects of the military industry, because its extraordinary advancement added a powerful weight to the victory in both the SinoJapanese and the Russo-Japanese Wars, with the result that, without doubt, the nation was greatly advanced materially and immaterially, and not only the industries, but the general economic world was benefited directly and indirectly. These events in the past economic world in Japan, the existence of which no one denies, prove that the military industry, which advanced on account of armament expansion often undertaken since the beginning of Meiji and the wars that took place during those years, seems to have been a conductor of the most proper industrial policy.

Now will those events as seen above, the economic effects of the military industry in the past, continue also for the future in the same condition? Or should they be made to do so? In other words, is it possible that the military industry stands in such a position as to lead or protect the general industries, especially the manufacturing industry, for the present and future as before? Or is it necessary for it to do so? The manufacturing industry among the people of Japan at the present time, having developed in a marked degree, is far different in its condition from that of some years ago. It is no longer necessary, when the popular industry has made such rapid progress as nowadays, that it follow behind the military industry and be led by the latter. Especially, some industries are running parallel to the latter-no, are even one step in advance-so that the latter can not longer be the leader. Not only with the manufacturing industry, but with any 
industry is this the case. It is, therefore, no difficult thing to foresee that, for the future, the military industry will not produce the same effects as before in the economic line, if we judge from the economic advancement at the present time in Japan. Although it will benefit the economic circle at large in future, its effect must gradually diminish, compared with the past. Moreover, in the case of that industry, such a large sum of expenditure is yearly paid that, according to the budget for 2 Taisho (I9I3), succeeded by that for the following year, it amounted to over 97,936,000 yen, ordinary and extraordinary together, for the military, and over 97,082,000 yen for the navy, or over $195,018,000$ yen in all, which sum corresponds to 33 per cent and a fraction of the whole budget of expenditures, ordinary and extraordinary, for the same year. Of these expenditures, those for the military industry are divided into the following items: those belonging to Special Accounts, including the expenses for the work of the Tokyo and Osaka Arsenals and the Senju Woolen Cloth Factory, funds of the Naval Arsenals, and the expenditure for the Naval Colliery, as well as the ordinary and extraordinary expenses belonging to General Accounts. In all they reached about ninety million yen, which corresponds to I 5 per cent and a fraction of the total sum of the annual expenditure in the budget for the same year. These expenditures, according to the figures of the latest years, are not merely making a marked increase, but the rate of increase, too, is being raised step by step, owing to the constant expansion of the armament and the invention of new weapons necessitated by the competition in armament among the countries of the world. As a result of the excessive expansion of Japanese finance caused by this fact, the capital among the people, which otherwise would have served for industries at large, was absorbed into the circle of the military, and thus occurred the gradual decrease of the capacity of the nation in economy and general industries. The profit which the military industry will bring to the national economy hereafter by its expansion perhaps amounts to nothing, if the loss caused by the same be set off-no, rather the latter might be greater. 
It is the natural conclusion that any person who, inferring the future benefits of the military industry by induction from the past events, will consider its expansion as more and more necessary for the development of the national economy of Japan, must be pronounced to be under a deep illusion.

We are now concluding our essay and have a few words to add. At present, the powerful states in the world are devoting themselves to armament expansion without limit, and Japan is year after year expanding her armament by making big guns and large warships with the utmost haste. If all countries compete with each other on such conditions, it can not but result in the exhaustion of national wealth. But even these world evils, from which no state can escape, may be modified and turned to advantage by the policy and the method of administration. 


\section{INDEX}

Accounting, in arsenals, 32,34 et seq.

Age, Yatabori, i 8.

Aginoura, establishment of iron works at, I9.

Agriculture, effect of military industries, 203 et seg.

Akamatsu-Noriyoski, Daijo (chief of Yolkosuka Naval Arsenal), 54.

Alcohol: manufacture of, 65; at Itabashi powder mill, $7 \mathrm{I}$.

Aluminum: use of, in shipbuilding, $8 \mathrm{I}$; in manufacture of lunch box and water bottle, I I 3 .

Ammunition: development of manufacture of, 14-15, 46 et seg.; factory for manufacture of, at Tokyo, 3I; enlargement of factory at Tokyo, 33; manufacture of, at Osaka Arsenal, 46; demand for, during Satsuma rebellion, 47; making of, for Murata rifle, $50-5 \mathrm{I}, 7 \mathrm{I}$; for mountain guns, $5 \mathrm{I}$; demand for, at time of Sino-Japanese War, 71. See also Powder.

Aomori (Oshu Province), shipbuilding at, 26.

Aoyama, special powder magazine at, 32.

Arisaka, Colonel Nariaka (chief superintendent of Tokyo Arsenal), 68-69.

Arms ("Teppo"): early use of, 3-4; first importation of, 5; manufacture of, 6-7; invention of quick-firing, 8 ; importation of "Gewehr" rifle, 8, 38; importation of "Minie" type, 9, 38; introduction of machine, 9; importation of "Fransu" type, Io; invention of turnable ("Sempudai"), II ; progress in manufacture of, 13; manufacture of mountain, field and breechloading, I 4,40 ; use of magazine rifle in army, 33; institute for examination of, 36-37; manufacture of gun carriages, 37; Enfield rifles, 38; imperfections in domestic, 39; rifles manufactured at Tokyo Arsenal, 4I; purchase of machinery for coast and siege, 4I ; remodeling of Enfields, 4I42; Murata rifle as standard, 42-43; remodeling of Chassepot, 42; manufacture of howitzers, 42; pattern for cavalry rifle, 42 ; rifles manufactured at Tokyo Arsenal, 43; progress in making of, 43; magazine rifles manu- factured at Tokyo Arsenal, 44; manufacture of coast, 44; manufacture of short fire, at Osaka Arsenal, 45; Krupp gun, 48-49, 72; improvement in, after Sino-Japanese War, 64; rifle of 3 oth year patterns and quick firing, 68 et seq.; Maxim machine and Hotchkiss machine, 68; increased need for, during and after Russo-Japanese War, 85 ; improvements in principal, 86-87.

Arms Office, work of, $30,38,46$.

Arsenals: at Tokyo and Osaka, 29; head, $3 \mathrm{I}$; organization and regulations of, 31 et seq.; accounting in, 32,34 et seg.; area of Osaka, 36; branches established, 37; revision of regulations of, 37-38; manufacture of small arms at Tokyo, 39; manufacture of guns at Osaka, 39; forging, casting and pattern making at Osaka, 40; expenditures of Osaka, 40; use of steam power in, 40; labor-saving devices used at Tokyo, 40-4I; manufacture of rifles at Tokyo, $4 \mathrm{I}$; increase of workmen in Tokyo, $4 \mathrm{I}$; gun carriage, cannon and mortar manufacture at Osaka, 43-44; harness manufacturing at Tokyo, 44, 99; shell manufacturing at, $46-47$; increase of machinery in, 47; manufacture of ammunition in Tokyo, 50; number of shells made at Osaka, 50; manufacture of shrapnel at Osaka, 5I; naval, at Yokosuka, $52,75-76,142$ et seq.; enlargement of, after Sino-Japanese War, 64; inspection of, by Arms Inspection Bureau, 65-66; workmen's relief, 66; number of workmen in, 66; employment of women in, 68; naval, at Maizuru, 75; I21, I 38; naval, at Tokyo, 75; torpedo-boat building at naval, 80 et seq.; manufacture of telephone and telegraph in, 90; manufacture of bridging materials in, 92; manufacture of automobiles in, 96; manufacture of horseshoes at, Ioo; present plan of, IOO-IOI; revenue, number of workmen and wages in, I02; principal articles manufactured in, 103 ; battleship, cruiser, destroyer and torpedoboat construction in, I2 I et seq.; instruction of workmen in, $17+$ et seq.; 
steel founding in, I 83 ; by-products manufactured in, 216 ; wages of workmen, 242 et seq.; medical treatment for employes, 248 .

Artillery Artificer Training School, 3 I.

Artisans: skill of, before Meiji Restoration, 4; advance of, in shipbuilding, I 7 .

Australia, imports from, 23 I.

Automobiles, 96.

Bacquet (French smith), as teacher, 41 . Balsing, I 74 ; fermentation system, I 78.

Bayonet, manufacture of, 69 .

Beef, canning of, I I 5.

Bicycles, use of, in Sino-Japanese IVar, 94.

Biscuit, making of, in arsenals, I I 5.

Bracialini, Scipione (Major), artillery teacher, 34,45 .

Bridges: military, 90-9I ; manufacture of materials for, at arsenals, 92 .

Briquette, manufacture of, I 54-I 55.

Bureau of Military Affairs, establishment of, 30 .

Canning, I73-I74, I94; of beef, I I 5.

Cannon, I4; manufacture of, in Osaka Arsenal, 42 et seq., 69 et seq.; manufacture of gun carriage, 43 et seq.

Canteen: machine for making, 69 ; number made (I9I0-I9I2), I I 4 .

Cartridges: manufacture of, in Osaka Arsenal, 46; for Murata rifle, 48, 5I; in Tokyo Arsenal, 50, $7 \mathrm{I}-72$.

Casting, 65; introduction of, in Osaka Arsenal, 40; labor saving methods used in, 40-4I; of bronze for cartridge cases, 49.

Central Medical Material Depot (later, Medical Material Department), object, 92.

Charcoal, manufacture of, 49.

"Closed Door" Policy, 7.

Clothing: manufacture of military, I03 et seq., I09 et seq., I 74 ; improvements in manufacture of, I 78, I93 et seg., 197 et seg.

Coal: used in woolen factories, Io6; naval colliery, I53; importation of, 153; profit and loss in operation of naval colliery, I54; smokeless, I 78 ; influence of military industries on use of, 208-209; consumption of, in army and navy factories, 2 I I ; annual imports of (I 868-I890), 222.

Conscription system, beginning of, 4 .

Corn, cleaning of, I I 5 .

Crane: electric, use of, 67 ; in shipbuilding, 126.
Creusot Company (France), torpedoboat parts imported from, 59-60.

Crimean War, I7-I8.

Cruisers: built (I $883-\mathrm{I} 888$ ), 57-58; program for building, after Sino-Japanese $\mathrm{War}, 74$; new program for, I 2 I et seq.

Curtius, Donker (Dutch Consul), I 8.

Department of Railway Materials, creation and object of, 64 .

Dispatch Boats, I2I-I 22, I27; built (I 883-I 888), 57.

Destroyers (Torpedo-Boat), 77 et seq.; domestic construction of, I I I-I22; new program for, I30 et seq.; I 88; improvements in construction, $13^{\circ}$ et seq.; details of construction of (from Russo-Japanese War to present time), I34-I 35 .

Dockyards: at Uraga, 52 ; at Kagoshima, 52; at Yokosuka, 54, 57; at Onohama, 54,57 ; at Ishikawa-Jima, 56-57; at Kawasaki, 56, I 27; at Tsukiji, 9 I ; at Mitsubishi, I 27; at Ryojun, I38.

Dynamite, tests of, at Itabashi powder mill, 73 .

Electricity, used in shell factory, 67 .

Engineers, from foreign countries, 3 .

Engines and Motors: in clothing and shoemaking factories, I I I-I I 2 ; summary of military industrial, I I 8-I I9; in shipbuilding, 143 et seg.; progress in manufacture of ship, I49, I89; factories for manufacture of, I50; for warships, I 5 I -I 52.

England: warships built by, 22, 74, 88; machines imported from, 47; destroyers built by, 77; imports from, 23 I.

Etchujima (Yedo), shipbuilding at, I6.

Ether: manufacture of, 65 ; at Itabashi powder mill, 71 .

Etorop Island, I3.

Exports, increase of, 217.

Factory of the Shipbuilding Bureau, $5^{2}$. Factories, 29 et seq., 64 et seq.; lack of, 4, 28; naval, 75; private, in manufacture of munitions after RussoJapanese War, 85 , I 83 et seq.; statistics of motive power, workmen and expenditures of Railway Material Department, 95-96; in manufacture of woolen cloth, I04 et seq., I I I ; importance of, I05; shoemaking, ro9, I I I; for haversacks and knapsacks, I 3 ; for engine making, I 5o; government protection of, I 7 I ; training of 
men in, 173 ; influence of military, on private, 2OI; coal consumption in army and navy, $2 \mathrm{I}$; effect of military, on trade, 2 I 5; effect of military, on population, 25I et seq.; sanitation in, 257.

Favius, Captain G., I 8.

Field Glasses, manufacture of, 34,45 .

Forestry, influence of military industries on, 206 et seq.

Forging, 65; beginning of, at Osaka Arsenal, 40.

Formosa, expedition to, 56, 217 .

Fornelis, Antonio, Italian engineer as teacher, 43-44.

France: officers from, as military instructors, 9, 2 I ; guns imported from, IO; visit of warships of, I2; imports from, 231 .

Fukiage, 30 .

Fulminate, mercuric, manufacture of, 65.

Furnace: introduction of duodecagonal reverberatory, 42; annealing, for cartridge case, 48-49; use of gas, 67 ; acid, at Osaka, 70, 73 .

Fuse, desmarets, 47 ; compound, 48 , 50-51, 72-73, 93; base, 50; alteration of base, 93; Krupp base, 93; percussion, 93-94.

Gaggenau Company (Germany), automobiles imported from, 96.

Gas, use of, in factories, 49.

Geki, Inouye, inventor, 9, I I.

Germany: warship built by, 22 ; imports from, $23 \mathrm{I}$.

Gishu, 95.

Glasgow, 20.

Goho (Chinese scholar), 5.

Great Britain: visit of fleet, I2; naval officers as instructors, $2 \mathrm{I}$; warships built by, 22 .

Grillo, Major Pompeio, Italian artillery instructor, 43,44 .

Gunboats, 56; built (I 883-I 888), 57 .

Gun cotton, manufacture of, 34,51 .

Gunpowder, 5; manufacture of, I 5, 75 .

Guns (See Arms).

Hachiman-mure, iron foundry at, I9o et seq.

Hagi, small arms factory at, 36, 4I.

Hakodate, shipbuilding at, 22, 24.

Hardes (Dutch naval engineer), I9.

Harness: manufacture of, 38,44, I 74 ; kinds of, 97 et seg.

Haruki (Izumi Province), gun examination institute at, 37 .
Haversacks, manufacture of, I I3, 200. Heer, German instructor in cartridge case manufacture, 48 .

Heta, I 7 .

Hida-Hamagoro, chief of Factory of Shipbuilding Bureau, 52.

Hideyoshi, Toyotomi, Io.

Himeji, shipbuilding at, 25; railway facilities at, 228 .

Hiroshima, 235; branch arsenal at, 37; manufacture of clothing at, I09; railway facilities at, 227 .

Hisso, Giacomo (Italian engineer), as instructor, 43.

Holland: instructions in gun making, 5; treaty of commerce with, 7 ; purchase of guns from, I3; advice on development of navy, I 7-I 8; help of instructors in naval training, I 8-I9; gift of battleship by, 22; imports from, 23 I.

Horses, equipment for, $97 \mathrm{et} \mathrm{seq.}$

Hotchkiss, machine gun, 68.

Horseshoes, manufacture of, 99-Ioo.

Hunhopas, 95.

Hyogo, iron works at, 52.

Hyuga-no-kami, Shibata, mission to France, 2 I.

Ichimu, Inatomi, 9.

Imports: of materials for military industries, I08-109, I I4, I I 7, I 82, 2 I 7, 2I9, 23I; comparison of annual, of principal metals (I868-I9I2), 22022 I ; of coal (I 868-I 890), 222.

Industries; rise of new, I67 et seg.; effect of Russo-Japanese War on, I 7o; protection of, I 7O-I 7 I ; effect of military, on national enterprises, I96-I97.

Instructors: French officers as military and naval, 9, I 4, 20-2 I, 40, 47, 54; Dutch, II, I8-I9; English, 2I; Belgian, to; Italian, 43 et seq.; German, 48.

Inventions, I 76 et seg.

Iron: establishment of, works at Aginoura, I9; at Nagasaki, 52; at Hyogo, 52 ; importance of, I 8 I, I 89 et seq., 209; imports of, $22 \mathrm{I}$.

Ishikawa-Jima (Yedo): shipbuilding at, 22 et seq., 56; Administrative Bureau at, under Navy Department, 53; dockyard at, I85.

Itabashi: powder mill, at, 3 I et seq.; enlargement of powder mill at, 33; powder making for small arms at, $4 \mathrm{I}$; for rifles, 47; for field and mountain guns, 49; making of niter and gun cotton at, 5I; manufacture of mercuric fulminate, ether and alcohol at, 65. 
Iwabana, 33; black powder manufactured at, 49 .

Izumi, 6, 10, I7, 36-37.

Izumishinden, special powder magazine at, 32 .

Jauly, Philippe, Belgian instructor in small arms making, 4o.

Jindayu, Kunitomo, machine gun mechanic, 9.

Kagezo, Yatabori, I 8.

Kagoshima: shipbuilding at, 22, 24; branch factory at, 35; dockyard at, 52.

Kaiser, Dutch instructor in gun manufacture, I I.

Kawasaki: dockyard at, I85; dispatch boat construction at, I27; submarine construction at, 137; equipment of dockyard at, 187 ; building of torpedoboat destroyers at, I 88 .

Kirby, owner of Onohama Dockyard, 54.

Knapsacks, manufacture of, I I 3 .

Kobe: naval factory and dockyard at, 20; Kawasaki Dockyard at, 56, I 85.

Koishikawa: manufacture of arms in factory at, 30 ; high explosives mill at, 32.

Kokura, 5 .

Krupp Gun, 48-49, 72.

Kumamoto: branch arsenal at, 37 ; rioting at, 4I, 47; railway facilities, 228 .

Kure: naval station, at 54-55, 75; shipbuilding at, $58,77,79$; torpedo-boat building at, 80-8I; battleship construction at, I 2 I, I 23 et seq.; plan and structures of naval arsenal at, I 44; number of workmen at, I 45; engine making at, 150; education plan of factory at, i 74 et seq.; steel founding at, 183; railway facilities, $225-226$; harbor facilities, 235-236; effect of shipbuilding on population of, 253 .

Labor-saving Devices, 37 et seq., 43, 48, 65 et seq.

Lathing: shell, 37, 49-50; hydraulic, at Tokyo Arsenal, 40.

Launching, abacus system of, $8 \mathrm{I}$.

Lebon, Captain, French artillery officer as instructor, 40 .

Lemoine, French caster, 40.

Lunch Boxes, manufacture of, 67, 69, I I 3-II 4 .

Machinery: lack of, 4; purchase of, in France, 21; primitive state of, 28 ; purchase of, to manufacture coast and siege guns, $4 \mathrm{I}$; for powder making, 44; increase of, in arsenals, 47 ; in Yokosuka Naval Arsenal, I43.

Machine Guns, introduction of, 9; Maxim and Hotchkiss, 68; improvements in, 86.

Maizuru Dockyard: construction of destroyers, cruisers and torpedo boats at, 121,188 ; repairing at, 138 ; plan and structures of, I47; number of workmen at, 148; engine making at, I50, railway facilities at, 228-229; harbor facilities, 237-238; effect of shipbuilding, 255 .

Manchuria, 89.

Manila, mountain guns manufactured for, 45 .

Manufacturing, III; expenditures for clothing and shoe (I9I0-I9I2), II 2 et seq.; amount, rate of increase, expenses, and number of workmen in provision, I16; condition of, before Restoration, 163; effect of military industries on, 182 et seq.

Margritte, Colonel, French military instructor, 40.

Masafusa, Hojo, I I.

Maxim, machine gun, 68 .

Medical Material Depot, object of, 92.

Meguro, II; enlargement of powder mill at, 65; labor-saving devices in powder mill, 66.

Melbourne (Australia), firearms manufactured for, 45 .

Military Central Provision Department, work of, II 5 .

Military Clothing Department, object of, 64 .

Military Veterinary School, 99.

Milling, of rice, 195.

Mining, influence of military industries on, 208 et seq.

Mito, Lord, I6.

Mitsubishi Dockyard, I 85; dispatch boat construction at, I 27 ; equipment of, i 87 ; torpedo-boat destroyer construction, I 88 .

Moji Arms Repairing Works, 67.

Mukden, 95.

Muroran: steel foundry at, $I 7 I$; harbor facilities, 239-240.

Nagasaki, I3, I8-19, I85; open to foreigners, 7 ; naval training school at, I8; warships built at, 22, 24-25; iron works, at 52 ; railway facilities, 228.

Nagasaki Naval Training School, establishment of, I8.

Nagoia, branch arsenal at, 37 . 
Naval factories and dockyards: construction of, 20; for Shimrose gun powder, 75; men employed in, I 57; wages of workmen, 242 et seq.; effect of, on population of towns, 252 .

Naval Stations: at Kure, 54 et seq.; expansion of Kure, 55, 75 et seq.; at Sasebo, 55, 75, 8I-82; at Yokosuka, 57,75 et seq., 142 et seg.; at Maizuru and Ominato, 74-75; at Takeshiki, 75; at Bako, 75; engine-making at, I50; men employed in, I 57 ; wages of workmen, 242 et seq.; effect of, on population of cities, 252 .

Navy Department: establishment of, $52-53,55 ; 20$-year plan of, 57 ; second naval expansion plan of, 57-58; program for enlargement of navy, 74; new naval plan, I2I-I22; engines used in naval industries, 156 .

Nishimura, 5

Niter, refining of, 49 et seg.

Nitro-glycerine, tests of, 73 .

Normand Company (France), 79; construction of torpedo boat by, 61.

Oda, Lord, i o.

Oji Chemical Works, 65; manufacture of yellow powder, $7 \mathrm{I}$.

Onohama Dockyard: number of ships built at, 54 et seq.; torpedo-boat building at, 59-6o.

Osaka, I I ; arsenal at, 29; regulations of arsenal at, 35-36, 39; activity of arsenal during Satsuma rebellion, 4I; use of reverberatory furnace at arsenal at, 42 ; manufacture of cannon at, 42-43; of gun carriage cannon and mortars at, $43-44$; of coast guns at, 44 ; of cartridges and shells at, 46, 49; shell-lathing at, 49-50; number of shells manufactured at, 50; manufacture of shrapnel at, 5I; enlargement of arsenal, 64 et seg.; manufacture of tools at, 70 ; of automobiles at, 96; of harness and other equipment, 99; plan of work and effect of factories on population of, $25 \mathrm{I}$; condition of work in arsenal at, IOO-IOI; manufacture of military clothing at, I09; shoe manufacturing at, I09; torpedo boat construction at, I3 I, I 87 ; steel founding, I 83 .

Otomo, Lord, 10.

Otsugawa (Izumi Province), institute for gun examination at, 36 .

Partray, French gun powder expert, 47. Pattern-making, at Osaka arsenal, 40. Peking, 94.
Pensions, of arsenal employes, 248.

Percussion caps, manufacture of, 46 et seg.

Perry, Commodore, visit of, 7 .

Perslecken, Dutch naval officer in charge of naval training school, I8.

Pickles, making of, I 15.

Pontoons, 87, 90; iron boats used for, 9 I.

Population, effect of military factories on, 25 I et seq.

Portugal, importation of guns from, Io

Powder: manufacture of, $3 \mathrm{I}$ et seg., smokeless, 34, 5o, 7o; for small arms, $4 \mathbf{I}$; for rifles, 47; manufacture of black, 49; of yellow, 7I. See also Ammunition

Powder mills: at Itabashi, 3 I et seq., 4I, 47, 5I, 65, 70; at Iwabana, 49; at Meguro, 5I, 65; at $\mathrm{Uji}, 66-67$.

Protection, of military industries, I 70I 7 I , 2 I 7-2 I 8.

Provision Department, creation and object of, 64, I94-I95.

Quaratezy, Major Alexandro, Italian instructor, 44 .

Railways: in arsenals, 37; battalions, 94-95; development of, 224 et seq.

Ram heads, disadvantages of, 124 .

Range finders: manufacture of, 34,45 ; study of foreign manufacture of, 68 .

Repairing: of warships, I $37^{-I} 38$; cost of warship, I 38 et seq; yards, I 38 .

Restoration (Meiji): causes of, 27-28; manufacturing before, I63.

Revenue, from operation of arsenals, I02.

Revolvers: 26th-year model, manufactured in Tokyo Arsenal, 45; Smith and Wesson, 50. See also Arms.

Rice, cleaning of, 195.

Rifles. See Arms.

Rintaro, Katsu, I8, 20-2 I

Riots, at Yamaguchi and Kumamoto, 4I, 47.

Roches, Léon, French ambassador, 20.

Russia: visit of warships of, I2-13; building of battleship for, 17 .

Russo-Japanese War, 9I, I 55, I6.4, I 7 I ; development of war implements during, 64; importance of, 85 ; effect on industry, I $70,183,187,191$; increase of imports during, 2 I 7 ; effect on railway development, 226.

Saga, shipbuilding at, 25 .

Samukaze-Zawa (Oshu Province), shipbuilding at, 25 . 
Sasebo Naval Arsenal: construction of destroyers, cruisers, and torpedo boats at, I 2 I, i2 27 et seq., I 88; repairing at, 138 ; plan and structures of, I 45; number of workmen at, I47; engine making at, I5\%; railway connections, 227-228; harbor facilities, 236-237; effect of shipbuilding on population of, 254.

Satsuma Rebellion, $32,36,48$, I69; outbreak of, 4I, 56, I68; effect on arms manufacture, 4I, 47, 217.

Schichan Company (Germany), 79, 82; manufacture of torpedo boats by, 6I.

Schools, military and naval technical, I 72, I 74 et seq.; night, I 73 .

Senju (Tokyo): woolen cloth factory at, 29, I03, I93 et seq.; manufactures of woolen factory at, I07; expenditures and receipts of woolen cloth factory at, Io8; value of products of factory at, 108 .

Seoul, 95 .

Sheep, raising of, 105.

Shells: manufacture of (I 830-I 843), I 5; at Osaka Arsenal, 46 et seq.; at Tokyo Arsenal, 47; progress in manufacture of, 50 ; use of electricity for casting of, 67 ; machine for making, for quickfiring field and mountain artillery guns, 67; manufacture of shrapnel, 72 .

Shimoda, I 7; shipbuilding at, 22, 24.

Shingu, shipbuilding at, 25.

Shipbuilding: early, I 6 et seq., 22 et seq.; at time of Restoration, 52; development of, 22 et seq., 53 et seq., 122, 124, I85 et seq.; private ownership in, I 86 ; effect of, on population of towns, 252 et seq.

Shipping, development of, due to military and naval industries, $23^{\circ}$ et seq.

Ships. See Warships.

Ships, repairs to. See Repairing.

Shoes, factory for manufacture of military, I09, I74.

Shonai, shipbuilding at, 25 .

Shrapnel, manufacture of, 51, 73 .

Sick relief, in military factories, 247 et seq.

Sinminting, 95 .

Sino-Japanese War, 38, 98, I 64, I 69-I 70; advance in military industry previous to, 29, $5 \mathrm{I}$; use of warships during, 58-59; expansion of army and navy after, 63, I86; enlargement of arsenals after, 64 et seq.; increased demand for ammunition during, 7I; government manufacture of provisions after, II5; increase of exports during, 217 .
Slaughter houses, establishment of, I I 5. Snaidel Canay Company (France), automobiles purchased from, 96.

Soy Extract, making of, I $15,204$.

Spain, 5; importation of guns from, 10.

Steam hammers, introduction of, 68.

Steamers, domestic construction of, 23 .

Steam power, use of, in arsenals, 40.

Steamship lines, 230 et seq.

Steel: manufacture of, in Osaka Arsenal 70; of nickel-chrome, 73; Japan Steel Foundry, I $7 \mathrm{I}, \mathrm{I} 83$; inventions in manufacture of, 177 .

Submarine boats, 83 ; domestic construction of, I36-I37.

Subsidies, to war material producers, I 66.

Takinogawa, powder mill at, 32 .

Tanegashima, 5-6.

Tarozaemon, Egawa, shell manufacturer, 9, I 5 .

Telegraph: introduction of, 88 ; corps, 88 ; improvements in, 89; lines constructed during Russo-Japanese War, 90 ; wireless, 90 .

Telephone: in arsenals, 65, 67; wireless, 90.

Tents, portable, I I 4 .

Thornycraft Company (England), automobiles imported from, 96.

Tokitaka, 5 .

Tokuyama, harbor facilities, 238.

Tokyo: arsenal at, 29; work of arsenal, 30-3 I, 39 et seq., labor saving devices in arsenal at, 40-4I ; increase of workmen in arsenal at, $4 \mathrm{I}$; in 1894,68 ; rifles manufactured in arsenal, 43-44; harness manufacture at, 44,99 ; shell manufacture at, 47; ammunition manufacture at, 50 ; enlargement of arsenal at, 64-65; naval arsenal at, 75; Central Medical Material Depot in, 92; manufacture of automobiles at, 96; plan of work and condition of arsenal at, IOO-IOI; military Central Provision Department at, I I 5 ; woolen cloth manufacture at, 193; influence of military factories on population of, $25 \mathrm{I}$.

Tomonotsu, shipbuilding at, 26 .

Tools, manufacture of edge, 70 .

Torpedo boats: introduction of, 59 et seq.; particulars of construction of, 60 ; building of (I 892-1 894), 62 ; program for building after Sino-Japanese War, 74, 79 et seq.; cost of construction, $8 \mathbf{I}$; built during Russo-Japanese War, I 35 et seq.

Training ships, built (I 883-I 888), 57 . 
Tsu, shipbuilding at, 25 .

Tsukiji: military school at, 19; Arms Bureau at, 53 .

Uji, powder mill at, 66.

Ujina, branch of Military Central Provision Department at, II 5 .

Unions, industrial, I 7 I.

United States, 19-20; warships built by, 22.

Uraga, 15; shipbuilding at, 16, 22, 24; dockyard at, 52-53, I 32, I 85, I 87 .

Wages: in arsenals, 102, 242 et seq.; in army and navy factories, 212; 242 et seq.

Wakamatsu, harbor facilities, 238.

Wakayama, branch factory, 35-36.

Warships: need of, 3; purchase of, abroad, 8; visits of foreign, I2, I5: growing interest in, 16; building of domestic, 22. I2 I et seq.; size and cost of navy (I 868), 22-23; improvement in construction of, $27-28,74$, I 87 ; constructed (I 872 ), 55-56; (I 883 I885), 57 ; (1876-1894), 62; used during Sino-Japanese War, 58 ; increased demand for, 63 ; details of construction of (from Russo-Japanese War to present time), I34-I35; details of engines for, 151-152; use of briquettes, 155 .

Warship Training School, foundation of, 19 .

Water bottle, manufacture of, I I3-I I4.

Water supply, 65.

Wireless telegraph, I 77 .

Women: employment of, in arsenals, 32,68 ; in factories, III; wages of, 243.

Workmen: increase of, in arsenals, 4I ; mutual relief of, 66, 243; numbers of; in arsenals, 66; in $1912,102,212$, wages of, in arsenals, 102, 212,242 et seq.; numbers of, in woolen factories, I06, III ; in shoemaking factories, I I I ; in military factories, I 20 , 2 I 2 ; number of, in Yokosuka Naval Arsenal, I43; number of, in Kure Naval Arsenal, I 45; number of, at Sasebo Naval Arsenal, I 47; number of, at Maizuru Naval Arsenal, I48; employed in naval factories, I57; training of, 173 et seq.; in Hachimanmure iron foundry, I92; Workmen's Mutual Relief Association, 243.

Workmen's Mutual Relief Association, work of, 243,249 et seq.

Workshops, 20-21.

Yamaguchi, rioting at, $4 \mathrm{I}$.

Yarrow Company (England), 59, 78 .

Yedo: shipbuilding at, 16; military school at, 19.

Yokohama: naval workshop at, 20; iron works at, 2I, I 85; factory at, 52 et seg.

Yokosuka: naval dockyard at, 20, I85: naval arsenal, $52-53 ; 75$; shipbuilding at, 56 et seq., 76 et seq., I 2 I et seq.; torpedo-boat construction at, $80-8 \mathrm{I}$; plans and structures of naval arsenal at, 142 et seq.; number of workmen at, I43; engine making at, 150 ; railway facilities at, 224-225; improvement of harbor facilities, 233 et seq.; effect of shipbuilding on population of, $25^{2}$.

Zinc plate: importation of, 47,220 ; inventions in manufacture of, I77; importance of, 2 IO. 


\section{-}




Roberts Library

$$
\begin{aligned}
& \text { DUE DATE: } \\
& \text { Apr. } 1,1995
\end{aligned}
$$

Fines 50 e per day

$$
\text { e renewals }
$$

Hours:

n. to Fri. 8:30 am to midnig sunday $1 \mathrm{pm}$ to $10 \mathrm{pm}$

For telephone renewals

call 978-8450

Hours: 9 to $9 \mathrm{pm}$

Mon. to 2 Sat. 9 am $105 \mathrm{pm}$

Sunday $1 \mathrm{pm}$ to $5 \mathrm{pm}$ aVE

How to

Search the internet on
UTLInk:

POCKET

BRARY

on the Net 


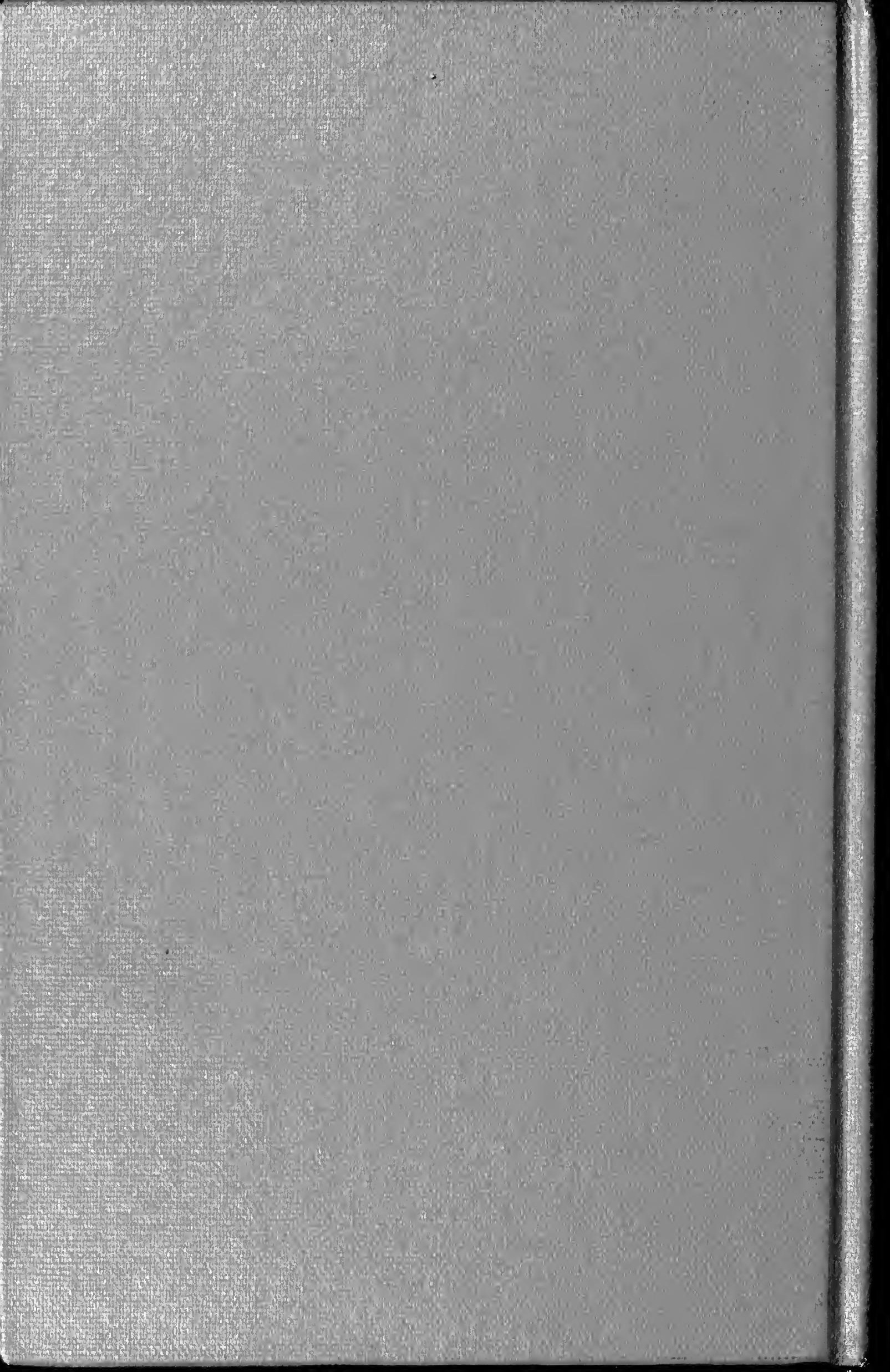

